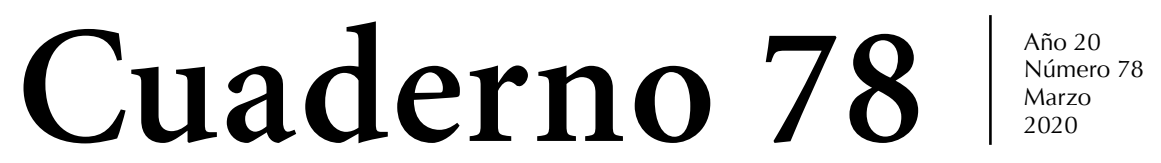

Cuadernos del Centro de Estudios en Diseño y Comunicación [Ensayos]

\title{
Tiempos inestables. Un mundo en transición
}

M. Veneziani: Prólogo | M. Veneziani: Diseño y cultura. Huellas japonesas en la Argentina | V.Martinez Azaro: Empatía y Diseño en un contexto de inmigración | X. González Eliçabe: La permanencia en el cambio. El poncho como bandera de libertad I V. Fiorini: Diseño de indumentaria: Nuevas estrategias de enseñanza y modelos de innovación en el marco del consumo de moda | C. Eiriz: La enseñanza de la metodología de la investigación en la era de la invención: Hacia un nuevo humanismo | M. Buey Fernández: Educar para no competir. La guerra de las naciones: nuevo escenario multipolar e innovación social como alternativa de adaptación | M. del M. Ketlun: Fases y redes en la metodología del Design Thinking | C. I. Galbusera Testa: La evolución de los modelos de enseñar-aprender diseño en el nuevo escenario generacional I M. F. Bertuzzi y D. Escobar: Identidad y nacionalismo. Una mirada sobre la búsqueda de identidad y nuevas tendencias en el diseño de modas | J. A. Di Loreto: Rembrandt: estética, sujeción y corporalidad | L. Mastantuono: Nostalgia Cinematográfica | S. Faerm: A World in Flux | S. Faerm: Contemplative Pedagogy in the College Classroom: Theory, Research, and Practice for Holistic Student Development | T. Werner: Preconceptions of the Ideal: Ethnic and Physical Diversity Fashion | M. G. Cyr: China: Hyper-Consumerism, Abstract Identity I N. Palomo-Lovinski and S. Faerm: Changing the Rules of the Game: Sustainable Product Service Systems and Manufacturing in the Fashion Industry | A. Sebek and J. Jones: Immersion in the Workplace: A Unique Model for Students to Engage in Real-World Service Design. 


Cuadernos del Centro de Estudios en

Diseño y Comunicación

Universidad de Palermo.

Facultad de Diseño y Comunicación.

Centro de Estudios en Diseño y Comunicación.

Mario Bravo 1050. C1175ABT.

Ciudad Autónoma de Buenos Aires, Argentina.

www.palermo.edu

publicacionesdc@palermo.edu

\section{Director}

Oscar Echevarría

\section{Editora}

Fabiola Knop

Coordinación del Cuaderno $\mathbf{n}^{\circ} 78$

Steven Faerm. (Parsons School of Design. USA)

Marcia Veneziani. (D\&C, UP. Argentina)

\section{Comité Editorial}

Lucia Acar. Universidade Estácio de Sá. Brasil.

Gonzalo Javier Alarcón Vital. Universidad Autónoma

Metropolitana. México.

Mercedes Alfonsín. Universidad de Buenos Aires.

Argentina.

Fernando Alberto Alvarez Romero. Universidad de

Bogotá Jorge Tadeo Lozano. Colombia.

Gonzalo Aranda Toro. Universidad Santo Tomás. Chile.

Christian Atance. Universidad de Buenos Aires. Argentina.

Mónica Balabani. Universidad de Palermo. Argentina.

Alberto Beckers Argomedo. Universidad Santo Tomás.

Chile.

Renato Antonio Bertao. Universidade Positivo. Brasil.

Allan Castelnuovo. Market Research Society. Reino

Unido.

Jorge Manuel Castro Falero. Universidad de la Empresa.

Uruguay.

Raúl Castro Zuñeda. Universidad de Palermo. Argentina.

Mario Rubén Dorochesi Fernandois. Universidad Técni-

ca Federico Santa María. Chile.

Adriana Inés Echeverria. Universidad de la Cuenca del

Plata. Argentina.

Jimena Mariana García Ascolani. Universidad Iberoame-

ricana. Paraguay.

Marcelo Ghio. Instituto San Ignacio. Perú.

Clara Lucia Grisales Montoya. Academia Superior de

Artes. Colombia.

Haenz Gutiérrez Quintana. Universidad Federal de Santa Catarina. Brasil.

José Korn Bruzzone. Universidad Tecnológica de Chile. Chile.

Zulema Marzorati. Universidad de Buenos Aires.

Argentina.

Denisse Morales. Universidad Iberoamericana Unibe.

República Dominicana.

\section{Universidad de Palermo}

Rector

Ricardo Popovsky

Facultad de Diseño y Comunicación

Decano

Oscar Echevarría

Secretario Académico

Jorge Gaitto
Nora Angélica Morales Zaragosa. Universidad Autónoma Metropolitana. México.

Candelaria Moreno de las Casas. Instituto Toulouse Lautrec. Perú.

Patricia Núñez Alexandra Panta de Solórzano. Tecnológico Espíritu Santo. Ecuador.

Guido Olivares Salinas. Universidad de Playa Ancha. Chile. Ana Beatriz Pereira de Andrade. UNESP Universidade Estadual Paulista. Brasil.

Fernando Rolando. Universidad de Palermo. Argentina. Alexandre Santos de Oliveira. Fundação Centro de Análise de Pesquisa e Inovação Tecnológica. Brasil.

Carlos Roberto Soto. Corporación Universitaria UNITEC. Colombia.

Patricia Torres Sánchez. Tecnológico de Monterrey.

México.

Viviana Suárez. Universidad de Palermo. Argentina.

Elisabet Taddei. Universidad de Palermo. Argentina.

\section{Comité de Arbitraje}

Luís Ahumada Hinostroza. Universidad Santo Tomás. Chile.

Débora Belmes. Universidad de Palermo. Argentina.

Marcelo Bianchi Bustos. Universidad de Palermo.

Argentina.

Aarón José Caballero Quiroz. Universidad Autónoma

Metropolitana. México.

Sandra Milena Castaño Rico. Universidad de Medellín. Colombia.

Roberto Céspedes. Universidad de Palermo. Argentina.

Carlos Cosentino. Universidad de Palermo. Argentina.

Ricardo Chelle Vargas. Universidad ORT. Uruguay. José María Doldán. Universidad de Palermo. Argentina. Susana Dueñas. Universidad Champagnat. Argentina. Pablo Fontana. Instituto Superior de Diseño Aguas de La Cañada. Argentina. 
Sandra Virginia Gómez Mañón. Universidad Iberoamericana Unibe. República Dominicana.

Jorge Manuel Iturbe Bermejo. Universidad La Salle. México.

Denise Jorge Trindade. Universidade Estácio de Sá. Brasil. Mauren Leni de Roque. Universidade Católica De Santos. Brasil.

María Patricia Lopera Calle. Tecnológico Pascual Bravo. Colombia.

Gloria Mercedes Múnera Álvarez. Corporación Universitaria UNITEC. Colombia.

Eduardo Naranjo Castillo. Universidad Nacional de Colombia. Colombia.

Miguel Alfonso Olivares Olivares. Universidad de Valparaíso. Chile.

Julio Enrique Putalláz. Universidad Nacional del Nordeste. Argentina.

Carlos Ramírez Righi. Universidad Federal de Santa Catarina. Brasil.

Oscar Rivadeneira Herrera. Universidad Tecnológica de Chile. Chille.

Julio Rojas Arriaza. Universidad de Playa Ancha. Chile. Eduardo Russo. Universidad Nacional de La Plata.

Argentina.

Virginia Suárez. Universidad de Palermo. Argentina. Carlos Torres de la Torre. Pontificia Universidad Católica del Ecuador. Ecuador.

Magali Turkenich. Universidad de Palermo. Argentina. Ignacio Urbina Polo. Prodiseño Escuela de Comunicación Visual y Diseño. Venezuela.

Verónica Beatriz Viedma Paoli. Universidad Politécnica y Artística del Paraguay. Paraguay.

Ricardo José Viveros Báez. Universidad Técnica Federico Santa María. Chile.

Textos en inglés

Victoria Martinez Azaro

\section{Diseño}

Francisca Simonetti - Constanza Togni

$1^{\circ}$ Edición.

Cantidad de ejemplares: 100

Ciudad Autónoma de Buenos Aires, Argentina.

Marzo 2020.

Impresión: Artes Gráficas Buschi S.A.

Ferré 250/52 (C1437FUR)

Ciudad Autónoma de Buenos Aires, Argentina.

ISSN 1668-0227

Cuadernos del Centro de Estudios en Diseño y Comunicación [Ensayos] on line

Los contenidos de esta publicación están disponibles, gratuitos, on line ingresando en:

www.palermo.edu/dyc $>$ Publicaciones DC $>$ Cuadernos del Centro de Estudios en Diseño y Comunicación.

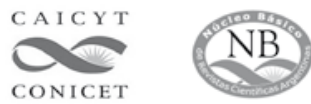

El Ministerio de Educación, Ciencia y Tecnología de la República Argentina, con la resolución № 2385/05 incorporó al Núcleo Básico de Publicaciones Periódicas Científicas y Tecnológicas -en la categoría Ciencias Sociales y Humanidades- la serie Cuadernos del Centro de Estudios en Diseño y Comunicación [Ensayos]. Facultad de Diseño y Comunicación de la Universidad de Palermo. En diciembre 2013 fue renovada la permanencia en el Núcleo Básico, que se evalúa de manera ininterrumpida desde el 2005. La publicación en sus versiones impresa y en línea han obtenido el Nivel 1 (36 puntos sobre 36).

\section{lat index}

La publicación Cuadernos del Centro de Estudios en Diseño y Comunicación [Ensayos] (ISSN 1668-0227) está incluida en el Directorio y Catálogo de Latindex.

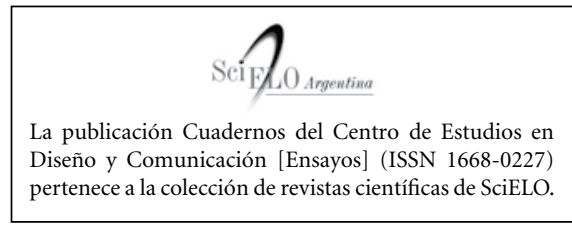

\section{O Dialnet}

La publicación Cuadernos del Centro de Estudios en Diseño y Comunicación [Ensayos] (ISSN 1668-0227) forma parte de la plataforma de recursos y servicios documentales Dialnet.
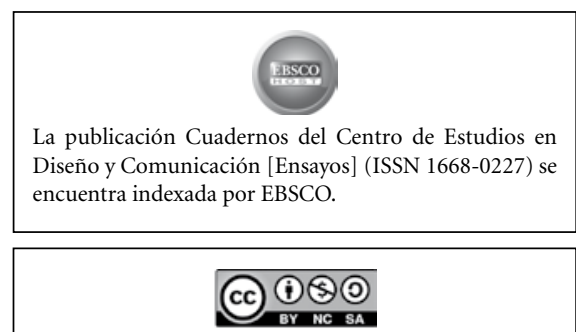

Esta obra está bajo una Licencia Creative Commons Atribución-NoComercial-CompartirIgual 4.0 Internacional

Prohibida la reproducción total o parcial de imágenes y textos. El contenido de los artículos es de absoluta responsabilidad de los autores. 



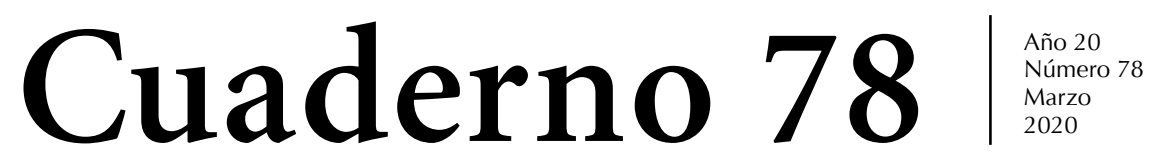

Cuadernos del Centro de Estudios en Diseño y Comunicación [Ensayos]

\section{Tiempos inestables. Un mundo en transición}

M. Veneziani: Prólogo | M. Veneziani: Diseño y cultura. Huellas japonesas en la Argentina | V.Martinez Azaro: Empatía y Diseño en un contexto de inmigración | X. González Eliçabe: La permanencia en el cambio. El poncho como bandera de libertad I V. Fiorini: Diseño de indumentaria: Nuevas estrategias de enseñanza y modelos de innovación en el marco del consumo de moda | C. Eiriz: La enseñanza de la metodología de la investigación en la era de la invención: Hacia un nuevo humanismo | M. Buey Fernández: Educar para no competir. La guerra de las naciones: nuevo escenario multipolar e innovación social como alternativa de adaptación | M. del M. Ketlun: Fases y redes en la metodología del Design Thinking | C. I. Galbusera Testa: La evolución de los modelos de enseñar-aprender diseño en el nuevo escenario generacional | M. F. Bertuzzi y D. Escobar: Identidad y nacionalismo. Una mirada sobre la búsqueda de identidad y nuevas tendencias en el diseño de modas | J. A. Di Loreto: Rembrandt: estética, sujeción y corporalidad | L. Mastantuono: Nostalgia Cinematográfica | S. Faerm: A World in Flux | S. Faerm: Contemplative Pedagogy in the College Classroom: Theory, Research, and Practice for Holistic Student Development | T. Werner: Preconceptions of the Ideal: Ethnic and Physical Diversity Fashion | M. G. Cyr: China: Hyper-Consumerism, Abstract Identity I N. Palomo-Lovinski and S. Faerm: Changing the Rules of the Game: Sustainable Product Service Systems and Manufacturing in the Fashion Industry | A. Sebek and J. Jones: Immersion in the Workplace: A Unique Model for Students to Engage in Real-World Service Design. 
Cuadernos del Centro de Estudios en Diseño y Comunicación. [Ensayos], es una línea de publicación cuatrimestral del Centro de Estudios en Diseño y Comunicación de la Facultad de Diseño y Comunicación de la Universidad de Palermo. Los Cuadernos reúnen papers e informes de investigación sobre tendencias de la práctica profesional, problemáticas de los medios de comunicación, nuevas tecnologías y enfoques epistemológicos de los campos del Diseño y la Comunicación. Los ensayos son aprobados en el proceso de referato realizado por el Comité de Arbitraje de la publicación.

Los estudios publicados están centrados en líneas de investigación que orientan las acciones del Centro de Estudios: 1. Empresas y marcas. 2. Medios y estrategias de comunicación. 3. Nuevas tecnologías. 4. Nuevos profesionales. 5. Diseño y producción de objetos, espacios e imágenes. 6. Pedagogía del diseño y las comunicaciones. 7. Historia y tendencias.

El Centro de Estudios en Diseño y Comunicación recepciona colaboraciones para ser publicadas en los Cuadernos del Centro de Estudios [Ensayos]. Las instrucciones para la presentación de los originales se encuentran disponibles en: http://fido.palermo.edu/servicios_dyc/publicacionesdc/ vista/instrucciones.php

Las publicaciones académicas de la Facultad de Diseño y Comunicación de la Universidad de Palermo actualizan sus contenidos en forma permanente, adecuándose a las modificaciones presentadas por las normas básicas de estilo de la American Psychological Association - APA. 
Cuadernos del Centro de Estudios en

Sumario

Diseño y Comunicación [Ensayos] No 78

ISSN 1668-0227

Facultad de Diseño y Comunicación.

Universidad de Palermo. Buenos Aires.

Marzo 2020.

Tiempos inestables. Un mundo en transición

Prólogo

Prologue

Marcia Veneziani.

..pp. 13-18

Diseño y cultura. Huellas japonesas en la Argentina

Design and culture. Japanese footprints in Argentina

Marcia Veneziani.

Empatía y Diseño en un contexto de inmigración

Empathy and Design in an immigration context

Victoria Martinez Azaro.

.pp. 29-37

La permanencia en el cambio. El poncho como bandera de libertad

The permanence in the change. The poncho as a freedom flag

Ximena González Eliçabe.

.pp. $39-50$

Diseño de indumentaria: Nuevas estrategias de enseñanza y modelos de

innovación en el marco del consumo de moda

Clothing design: New teaching strategies and innovation models in the

context of fashion consumption

Verónica Fiorini.

.pp. 51-60

La enseñanza de la metodología de la investigación en la era de la invención:

Hacia un nuevo humanismo

Teaching the methodology of research in the era of invention: Towards a

new humanism

Claudio Eiriz

.pp. 61-78 
Educar para no competir. La guerra de las naciones: nuevo escenario multipolar e innovación social como alternativa de adaptación Educate not to compete. The war of nations: a new multipolar scenario and social innovation as an alternative to adaptation

Fases y redes en la metodología del Design Thinking

Phases and networks in the Design Thinking methodology

María del Mar Ketlun.

La evolución de los modelos de enseñar-aprender diseño en el nuevo escenario generacional

The evolution of teaching-learning design models in the new generation scenario

Carmen Inés Galbusera Testa

Identidad y nacionalismo. Una mirada sobre la búsqueda de identidad y nuevas tendencias en el diseño de modas Identity and nationalism. A look at the search for identity and new trends in fashion design

María Florencia Bertuzzi y Daniela Escobar

Rembrandt: estética, sujeción y corporalidad

Rembrandt: aesthetics, subjection and corporality

Juan Alberto Di Loreto.

.pp. 129-139

Nostalgia Cinematográfica

Cinematic nostalgia

Laura Mastantuono. .pp. 141-151

Un mundo en transición. Introducción

A World in Flux. Introduction

Steven Faerm

Pedagogía Contemplativa en el Aula Universitaria: Teoría, Investigación y

Práctica para el Desarrollo Estudiantil Holístico

Contemplative Pedagogy in the College Classroom: Theory, Research, and

Practice for Holistic Student Development

Steven Faerm

Preconceptos del ideal: Moda de diversidad étnica y física

Preconceptions of the Ideal: Ethnic and Physical Diversity Fashion

Thomas Werner. .pp. 183-193 
China: hiperconsumismo, identidad abstracta

China: Hyper-Consumerism, Abstract Identity

Marie Genevieve Cyr

Cambiando las reglas del juego: Sistemas de servicio de productos

sostenibles y fabricación en la industria de la moda

Changing the Rules of the Game: Sustainable Product Service Systems and

Manufacturing in the Fashion Industry

Noël Palomo-Lovinski and Steven Faerm

Inmersión en el lugar de trabajo: un modelo único para que los estudiantes participen en el diseño de servicios en el mundo real Immersion in the Workplace: A Unique Model for Students to Engage in Real-World Service Design

Anezka Sebek and John Jones.

Curriculum Vitae completo de los autores

Full version of authors' biographies

pp. $247-252$

Publicaciones del CEDyC

pp. $253-279$

Síntesis de las instrucciones para autores................................................................ 280 

Resumen: El mundo actual está atravesando un cambio en variados aspectos: climáticos, económicos, políticos, flujos migratorios que se desplazan de un extremo al otro del planeta, retrocesos a formas de gobierno nacionalistas, conflictos armados por causas religiosas, políticas, económicas y cambios en las comunicaciones. Ante este panorama intolerante, impreciso y cambiante nos propusimos reflexionar una vez más, conjuntamente norteamericanos y argentinos, en cómo se expresan estas cuestiones en el arte y el diseño.

Palabras clave: Diseño - transición - globalización - comunicaciones - metodologías de enseñanza.

[Resúmenes en inglés y portugués en las páginas 17-18]

(*) Doctora en Comunicación Social y Licenciada en Publicidad (USAL). Profesora de la Universidad de Palermo en el Área de Investigación y Producción de la Facultad de Diseño y Comunicación. Es autora de los libros La Imagen de la Moda, y Moda, Economía y Sociedad. Además de escribir numerosos ensayos sobre comunicación, ha coordinado publicaciones académicas internacionales con la Universidad de Palermo y la Università di Bologna, y Parsons The New School for Design, entre otras. Especialista en temas de comportamiento de Moda y Consumo. Miembro del Comité Editorial de la Revista ZoneModa Journal, dedicada a los estudios de moda en Italia, Universitá di Bologna, Italia, desde julio de 2013. Directora de las Jornadas de Moda y Pensamiento: "Hipermoda". Fundación Ortega y Gasset Argentina (2015) y miembro del staff del Centro de Estudios Latinoamericanos de La Abadía y del Centro de Diplomacia Karina Vilella. Ha sido Profesora Titular en la Maestría en Comercialización y Comunicación Publicitaria de la Universidad del Salvador. También se desempeñó en importantes agencias de publicidad, organizaciones educativas y ha colaborado con diversos medios de comunicación y prensa en temas que tratan sobre su especialidad. Pertenece a la Facultad de Diseño y Comunicación desde el año 2009. Forma parte del Cuerpo Académico del Doctorado en Diseño, de la Maestría en Gestión del Diseño y del Equipo de Evaluación de Proyectos de Graduación. Miembro del Plenario de la Comisión de Posgrado DC. Dirige la Línea de Investigación Nuevos Paradigmas en la Enseñanza de la Moda y el Diseño. 
El Proyecto de Investigación entre la Facultad de Diseño y Comunicación de la Universidad de Palermo y Parsons The New School for Design nace en el año 2012 para generar una nueva línea de estudio, indagación y debate entre ambas Instituciones denominada Nuevos paradigmas en la enseñanza de la moda y el diseño.

Esta línea de investigación se desarrolla bajo la coordinación conjunta entre los profesores Marcia Veneziani por la Facultad de Diseño y Comunicación de la Universidad de Palermo (quien prologa los textos de los autores argentinos), y de Steven Faerm por Parsons The New School for Design (quien por su parte introduce a los autores norteamericanos en las siguientes páginas).

Es así, que en esta cuarta publicación, y bajo el título: Tiempos inestables. Un mundo en transición, se analiza el impacto del contexto internacional en el Diseño.

El mundo actual está atravesando un cambio en variados aspectos: climáticos, económicos, políticos, flujos migratorios que se desplazan de un extremo al otro del planeta, retrocesos a formas de gobierno nacionalistas, conflictos armados por causas religiosas, políticas, económicas y cambios en las comunicaciones.

Vivimos en medio de dudas y ansiedades por un futuro de lo más incierto. La globalización pareciera estar atravesándolo todo. Tu problema es mi problema. Un cambio aquí provoca un efecto en la otra parte de la tierra.

El término acuñado por Edward Norton Lorenz al desarrollar la Teoría del Caos y cuya traducción sería: ¿El aleteo de una mariposa en Brasil puede originar un tornado en Texas? parecería reflejar más cada vez más nuestra cotidianidad. Ante este panorama intolerante, impreciso y cambiante nos propusimos reflexionar una vez más, conjuntamente norteamericanos y argentinos, en cómo se expresan estas cuestiones en el arte y el diseño. A costa de ser juzgados de superficiales decidimos encarar la ardua tarea de reflexionar sobre el presente (es más sencillo hacerlo hacia atrás, con numerosos análisis y estudios a disposición).

¿Cómo encararemos el futuro en las áreas que nos competen? ¿Habrá que hacer cambios radicales en las metodologías de enseñanza? ¿Cómo está afectando la globalización en nuestros territorios y en las aulas multiculturales? ¿Cómo se reflejan estas transformaciones en nuestra forma de vincularnos con el diseño y cómo se expresan en sus diversas ramas? ¿Cómo influyen culturas del otro extremo del planeta en nuestro modo de vivir, vestir y diseñar? ¿Qué dirán de nosotros en el futuro cuando estudien nuestro modo de vida actual?

Reflexionamos, proponemos y cuestionamos a este mundo en transición. Esa es la invitación que hicimos a nuestros autores y que a continuación se exponen.

Marcia Veneziani en Diseño y cultura. Huellas japonesas en la Argentina explora los vínculos entre ambos países a través de la cultura. La colectividad japonesa en la Argentina (los nikeis) asciende aproximadamente a 65.000 personas.

Dado el progresivo interés por la cultura nipona en este país, en el presente ensayo se intenta analizar el vínculo entre los conceptos filosóficos de instante, vacío, ambigüedad y vulnerabilidad, para relacionarlos con el diseño, el arte, la estética, la filosofía Zen y la naturaleza. El kimono, la puerta característica denominada shöji, sus marcos de madera y papel washi, la poesía Haiku, el blanco y las sombras, son algunos de los ejemplos que se abordan para explicarlo. 
El texto ahonda en escritos de reconocidos autores japoneses como Junichirō Tanizaki, Kenya Hara y el argentino Jorge Luis Borges, profundizando con una entrevista de la autora a una filósofa japonesa actualmente residente en la Argentina, quien sostiene que en un mundo en transición, resulta primordial tomar conciencia de lo vernáculo en el arte y en el diseño, ponerlo de manifiesto tanto en la forma como en la materia y estar en armonía con el ambiente y con la propia interioridad.

Victoria Martinez Azaro en Empatía y Diseño en un contexto de inmigración, presenta una mirada auto-reflexiva basándose en su propia producción como diseñadora de indumentaria y artista. Esta argentina que emigró a Nueva Zelanda hace más de dos décadas y que se desempeña como docente en el Whitecliffe College of Art and Design de ese país, expone la complejidad de su universo interior en un mundo en transición. Indaga la propia producción desde el mismo presente, poniendo en evidencia conceptos del lenguaje, valores personales y sociales que vincula con procesos sustentables de empatía.

La autora realiza una investigación teórica a su propia producción creativa como inmigrante latina en Nueva Zelanda, ahonda en el alejamiento, desde la propia percepción e identidad y su reconstrucción. Analiza la problemática de la cuestión, no solo vinculada al lenguaje sino también a aspectos relacionados con el contrato social y cultural del país de acogida.

Ximena González Eliçabe en La permanencia en el cambio. El poncho como bandera de libertad analiza la prenda simbolo de nuestra identidad nacional.

El texto resulta más que oportuno para la presente publicación, ya que el contexto en que el poncho se consolida y propaga en América incluye algunas causas que continúan presentes en la actualidad: inmigración; diásporas; aumento de nacionalismo y disparidad económica.

En 2017 se cumplieron 200 años del Cruce de los Andes realizado por José de San Martín y el Museo de Arte Popular José Hernández de la ciudad de Buenos Aires, decidió festejar este acontecimiento histórico con la exposición Ponchos en el Bicentenario de nuestro país. La reconocida docente y curadora de la muestra es quien escribe este escrito ofreciendo al lector un valioso aporte educativo para nuestro país y para aquellos que deseen conocer la historia de la prenda ícono de nuestra cultura popular.

En la actualidad, el poncho es tendencia en las pasarelas internacionales y también en la calle, dando testimonio de la identidad local en el mundo global actual.

Verónica Fiorini en Diseño de indumentaria: Nuevas estrategias de enseñanza y modelos de innovación en el marco del consumo de moda sostiene que el contexto cultural y social contemporáneo, ya sea global o local, presenta profundos y marcados cambios y tensiones entre las tradiciones disciplinares, las habilitadas por aquellas y las posibles disoluciones. Apunta a la vigencia del proceso de construcción del diseño y sus significados, más que a la producción de los propios indumentos. Para ello, ahonda en textos de Baudrillard, Bourdieu y Verón.

La autora propone pensar cambios en la metodología del diseño de indumentaria en función de las metamorfosis socioculturales vinculadas al consumo. Así, propone una revisión más que necesaria de algunas nociones disciplinares, ya sea desde el enfoque metodológico vinculado a la innovación, como así también a los alcances discursivos entre los objetos de diseño y las experiencias de consumo. 
Claudio Eiriz en La enseñanza de la metodología de la investigación en la era de la invención: Hacia un nuevo humanismo reflexiona acerca del discurso respecto de los estilos de aprendizaje de las nuevas generaciones, los cambios que se han producidos a partir de las Tics, poniendo en evidencia las consecuencias que estas transformaciones pueden ocasionar en la enseñanza de la metodología de la investigación, haciendo especial énfasis en los contextos de descubrimiento e invención. El autor indaga y cuestiona a variados autores, exponiendo de modo creativo y desafiante el pensamiento de aquellos.

Cuando hace referencia a la invención concluye que la misma

Tiene una lógica tan compleja como la puesta a prueba de hipótesis. Aunque hayamos objetivado la memoria y ciertas operaciones de cómputos; aunque las máquinas lo hagan mejor que nosotros, los procesos de invención requieren de operaciones lógicas y poéticas complejas y de amplios conocimientos en variados campos del saber.

Mercedes Buey Fernández en Educar para no competir. La guerra de las naciones: nuevo escenario multipolar e innovación social como alternativa de adaptación realiza una mirada contextual de la actualidad, preguntándose: ¿qué utilidad tendría si no, el nuevo conocimiento, más que el de llevar a desarrollar comportamientos nuevos? Así, se trata de formar profesionales capaces de reconocer los cambios y tendencias actuales, las necesidades que implica detectar las implicancias y oportunidades estético-comunicativas y técnico-productivas; así como éticas, económicas, políticas y ambientales de sus propuestas, con el fin de producir nuevos productos, y con ellos, nuevos lenguajes comunicativos. La clave sería entonces, ser capaces de hallar ocasiones de diseño e intentar dotar de significado al término diseño analizando el contexto y actuar en consecuencia de modo crítico e innovador.

María del Mar Ketlun en Fases y redes en la metodología del Design Thinking se pregunta: ¿cómo innovar si se dice que todo está inventado? La respuesta podría ser: lo inventado puede ser reinventado.

Para ello, la autora explica la metodología del Design Thinking, la cual consistiría en utilizar aquello que percibimos y conocemos, logrando representar conceptos y estableciendo una correspondencia entre los componentes del problema según características estructurales, superficiales, objetivos del razonador y exigencias del entorno, con personas como factor clave, para lograr salir de la idea de uno mismo y generar empatía con los demás.

La autora propone secuencias y pasos para llevar a la práctica la innovación que puede ser empleada por emprendedores, empresas y creativos.

Carmen Inés Galbusera Testa en La evolución de los modelos de enseñar-aprender diseño en el nuevo escenario generacional indaga y profundiza en nuevos y en ya existentes modelos de aprendizaje vinculados a las distintas generaciones.

La autora se pregunta: ¿Qué impactos se perciben en los aprendizajes frente a la irrupción de las más recientes generaciones?

Un artículo que invita a repensar el modo de enseñanza-aprendizaje y el modo de facilitar las relaciones entre aquellas. 
Sostiene que para lograr un principio de entendimiento y comunicación entre diferentes generaciones es fundamental intentar conocer las características, las posibles raíces y condicionamientos de las mismas, con sus particularidades, considerando sus aspectos extraordinarios y sus limitaciones.

Para ello, recopila y fundamenta articuladamente sus afirmaciones con fuentes de diversos estudiosos e Instituciones internacionales.

María Florencia Bertuzzi y Daniela Escobar en Identidad y nacionalismo. Una mirada sobre la búsqueda de identidad y nuevas tendencias en el diseño de modas sostienen que en el contexto mundial actual: político, económico y social, se requiere un cambio de paradigma en la producción de moda a partir de la toma de conciencia del impacto medioambiental que se genera. Y no sólo. También en la economía y el consumo. Por lo tanto, el rol del diseñador de indumentaria se encuentra afectado por estas condiciones.

En el artículo se pone en evidencia, por lo tanto, un vínculo más comprometido, no sólo con la ética profesional sino también con la necesidad de crear y marcar una identidad propia de los creadores emergentes.

Juan Alberto Di Loreto en Rembrandt: estética, sujeción y corporalidad revisita el pasado y analiza no sólo la producción, sino también el contexto del pintor holandés Rembrandt Harmenszoon van Rijn. Su intención es indagar en los cambios y en las ideas respecto de la subjetividad y el cuerpo que se dan en el mundo europeo a comienzos del siglo XVII.

El autor toma el caso de Rembrandt como paradigmático para explicar la importancia que había adquirido como valor la propia representación, a modo de ejercicio artístico, pero también como muestra de una nueva sensibilidad singular. Luego, lo vincula con la actualidad para intentar comprender cómo fueron los comienzos de una concepción de la corporalidad y su relación en épocas de transición. En sus mismas palabras:

A través de las llamadas lecciones de anatomía y sus autorretratos, Rembrandt da cuenta de la racionalización, la aparición del individuo y objetivación de la corporalidad: de un cuerpo unido a la comunidad en la Edad Media, a la representación en la Modernidad de un cuerpo como un objeto inerte; del sujeto comunitario a la percepción del sujeto como unidad.

Laura Mastantuono en Nostalgia Cinematográfica, sostiene que en la actualidad existe una tendencia al revisionismo histórico.

Las nuevas generaciones, según la autora, vuelven al fílmico, con el fin de dominar las técnicas del oficio y citando a catedráticos americanos lo fundamenta diciendo que así lo prefieren, por la poética que brinda.

La autora remata:

En el diseño y comunicación audiovisual, la inestabilidad discursiva y formal dan lugar a una búsqueda artística hacia lo analógico y estudios sobre la importancia del archivo audiovisual y el found footage; axiomáticamente se entiende éste criterio como un accionar seguro sobre lo conocido, y un intento de comprender de manera objetiva el pasado. 


\begin{abstract}
The world today is changing in various ways: in terms of climate, economy, politics, migration waves which travel from one end of the planet to the other, relapses to nationalist governments, armed conflicts for religious, economic or political reasons, and changes in communication. In this intolerant, ambiguous and changing state of things, our purpose once again -in a joint effort between Argentineans and Americans- is to reflect on how to express these issues in art and design.
\end{abstract}

Keywords: designs - transition - globalization - communication - teaching method.

Resumo: $\mathrm{O}$ mundo atual está passando por uma mudança em vários aspectos: climáticos, econômicos, políticos, fluxos migratórios que se movem de um extremo do planeta para outro, retrocessos para formas nacionalistas de governo, conflitos armados para fins religiosos, políticos, econômicos e mudanças comunicações. Diante dessa paisagem intolerante, imprecisa e cambiante, procuramos refletir mais uma vez, junto aos norte-americanos e argentinos, como essas questões se expressam na arte e no design.

Palavras chave: Design - transição - globalização - comunicações - metodologias de ensino.

[Las traducciones de los abstracts fueron supervisadas por el autor de cada artículo] 
Fecha de recepción: abril 2019

Fecha de aceptación: octubre 2019

Versión final: marzo 2020

\section{Diseño y cultura. Huellas japonesas en la Argentina}

\author{
Marcia Veneziani *
}

\begin{abstract}
Resumen: Dado el creciente interés por la cultura japonesa en la Argentina, en el presente ensayo se intenta analizar el vínculo entre los conceptos de instante, vacío, ambigüedad y vulnerabilidad, para relacionarlos con el diseño, el arte, la estética, la filosofía Zen y la naturaleza. El kimono, la puerta característica denominada shöji, sus marcos de madera y papel washi, la poesía Haiku, el blanco y las sombras, son algunos de los ejemplos que se abordan para explicarlo. Resulta esencial además, comprender que también el lenguaje japonés, está indisolublemente ligado al diseño y a su filosofía. Para un japonés hablar y escuchar es un verdadero arte. Es por ello que el escrito aborda la cuestión a partir, no solo de los textos de Kenya Hara, Junichirō Tanizaki y de Jorge Luis Borges, sino que además incluye -necesariamente- un diálogo entre la autora del presente artículo y la filósofa nipona Mami Goda, residente en la Argentina desde hace casi una década.
\end{abstract}

Palabras clave: cultura japonesa - vacío - instante - ambigüedad - vulnerabilidad - diseño - arte - filosofía Zen - Haiku - kimono.

[Resúmenes en inglés y portugués en la página 28]

${ }^{(*)}$ Doctora en Comunicación Social y Licenciada en Publicidad (USAL). Profesora de la Universidad de Palermo en el Área de Investigación y Producción de la Facultad de Diseño y Comunicación. Es autora de los libros La Imagen de la Moda, y Moda, Economía y Sociedad. Además de escribir numerosos ensayos sobre comunicación, ha coordinado publicaciones académicas internacionales con la Universidad de Palermo y la Università di Bologna, y Parsons The New School for Design, entre otras. Especialista en temas de comportamiento de Moda y Consumo. Miembro del Comité Editorial de la Revista ZoneModa Journal, dedicada a los estudios de moda en Italia, Universitá di Bologna, Italia, desde julio de 2013. Directora de las Jornadas de Moda y Pensamiento: "Hipermoda". Fundación Ortega y Gasset Argentina (2015) y miembro del staff del cuerpo académico del Centro de Estudios Latinoamericanos de La Abadía y del Centro de Diplomacia Karina Vilella. Ha sido Profesora Titular en la Maestría en Comercialización y Comunicación Publicitaria de la Universidad del Salvador. También se desempeñó en importantes agencias de publicidad, organizaciones educativas y ha colaborado con diversos medios de comunicación y prensa en temas que tratan sobre su especialidad. Pertenece a la Facultad de Diseño y Comunicación desde el año 2009. Forma parte del Cuerpo Académico del Doctorado en Diseño, de la Maestría en Gestión del Diseño y del Equipo de Evaluación de Proyectos de 
Graduación. Miembro del Plenario de la Comisión de Posgrado DC. Dirige la Línea de Investigación Nuevos Paradigmas en la Enseñanza de la Moda y el Diseño.

Las relaciones diplomáticas entre la Argentina y Japón se iniciaron en 1898, con la firma del Tratado de Amistad, Comercio y Navegación.

El vínculo entre ambos países se fue afianzando debido a la inmigración japonesa en nuestro país. Luego de la Segunda Guerra Mundial, en la cual fueron suspendidas las relaciones bilaterales por la declaración de guerra por parte de Argentina hacia Japón en marzo de 1945, volvieron a restaurarse en el año 1952 con la firma del Tratado de Paz. Como indica en su página web, la Embajada de Japón en la Argentina, ambos países "han firmado un Acuerdo de Migración (1963), un Tratado de Amistad, Comercio y Navegación (1967), un Convenio sobre Cooperación Técnica (1981) y un Convenio Cultural (1981)" (Embajada de Japón en la Argentina, 2018).

A partir del año 2015 que este vínculo comenzó a crecer de modo más perceptible.

En la Argentina se realizan anualmente más de cien actividades ligadas con Japón, por ejemplo: se celebra la fiesta de Japón; se dictan clases de idioma japonés; comida japonesa; animé y cine japonés. Además se difunde la cultura japonesa tradicional, como por ejemplo, la ceremonia del té, ikebana, música y caligrafía japonesa. De esta manera, se está avanzando en el entendimiento mutuo entre los pueblos de Argentina y Japón (Embajada de Japón en la Argentina, 2018).

La colectividad de ese país en la Argentina (los nikeis) asciende a 65.000 personas.

En los dos últimos años, las actividades culturales de Japón en la Argentina se han visibilizado aún más, y enriquecido desde los más diversos ámbitos.

Con el convencimiento que la cultura es una de las tantas formas de entendimiento entre los pueblos, y observando el interés creciente por parte de diseñadores argentinos hacia el arte japonés, es que este ensayo pretende explorar la cultura japonesa con el fin de exponerla en estos escritos universitarios. Para ello, además de emplear bibliografía pertinente, se entrevistó a la filósofa nipona Mami Goda, quien reside en nuestro país desde hace poco más de ocho años.

Mami Goda nació en Japón, estudió Filosofía en la prestigiosa universidad francesa ParisSorbonne y en la École du Louvre, se especializó en reflexión sobre el arte. Trabajó en casas de subasta en las ciudades de París y en Tokio. En Buenos Aires es profesora, intérprete y traductora de japonés. Desde el año 2013 escribe para el periódico de la colectividad japonesa La Plata Hochi y ha colaborado en distintos medios gráficos y proyectos e intercambios de arte entre Argentina y Japón.

-MV: ¿Qué huellas del diseño japonés encuentras en la Argentina en la actualidad?

-MG: Hay mucho interés por lo que hay detrás del arte japonés: la filosofía, el pensamiento, la mirada hacia la naturaleza, la cultura. 
-MV: ¿Cómo interpretarías ese interés a partir de la filosofía? Por toda la crisis de occidente se puede pensar que estamos metidos en un consumismo desenfrenado... ¿Cómo lo expresarías desde la filosofía japonesa?

-MG: En Japón no tenemos esta mirada del dualismo entre el bien y el mal, lo correcto e incorrecto o lo bello y lo feo. En Japón hay una ambigüedad en la forma de ser, de ver las cosas, de hablar y de cómo es una belleza. Algo bello puede ser imperfecto.

-MV: Me interesa hablar de algunos conceptos que son clave en la cultura japonesa. Por ejemplo el de vacío ¿Los occidentales le tenemos horror al vacío, siempre hay algo que llenar... ¿cómo entiende este concepto un japonés?

-MG: Para nosotros el vacío es algo positivo. En el sentido que da todo un campo libre para la interpretación. El vacío es posibilidad, es algo que te tranquiliza, que da paz. Como algo meditativo, el vacío es silencio.

-MV: ¿Y cómo lo ves reflejado en la arquitectura o en el diseño de interiores?

-MG: Por ejemplo, si ves los objetos de la marca Muji no hay dibujos, motivos, es todo muy simple. Kenya Hara el Director artístico y diseñador japonés de la cadena de tiendas Muji, También es el Director artístico de la Japan House que se construyó en San Pablo. Él muestra dos fotos donde explica la diferencia entre dos cuchillos: uno es alemán, con un diseño muy funcional y otro un cuchillo japonés. El alemán tiene un diseño ergonómico, muestra cómo se encaja directo en tu mano. Es decir, tu mano no tiene que buscar cómo tiene que tomarlo, no tienes que pensar. El cuchillo japonés en cambio, es como muy finito, largo. Él lo toma como ejemplo para decir que el espacio del cuchillo alemán está lleno en cambio el japonés está vacío. Este último, dependiendo de cómo lo tomas, cambia la forma de cortar, qué cosa tienes que cortar. Si usas la punta para cortar es para hacer un fileteado del pescado crudo. Si lo utilizas más cerca de la mano, cortas más grueso. Kenya Hara afirma que es blanco porque es la función la que tienes que llenar al emplearlo.

-MV: ¿Cómo vinculas al kimono con el vacío?

-MG: Es justamente eso, tienes que decidir cómo te lo pones, cómo lo armas. Hay muchos diseñadores de la moda que construyen a partir de la forma de un maniquí, en cambio un kimono no. Es una forma única y un talle único que se adapta a cualquier cuerpo. Esto se está viendo acá también.

Es la técnica de furoshiki. Es una sola tela cuadrada, hay muchas maneras de envolver... es un poco como ésta: hay un modo para envolver una botella, dos botellas, una caja cuadrada, una caja redonda...en ese sentido la tela es vacía, es decir, tiene posibilidades. El kimono también...tiene un corte tan simple...en ese sentido entendemos el vacío.

En el diseño de Jardín también se aplica el vacío, lo mismo que en el Zen. Existe un vínculo muy fuerte de ese concepto dentro de toda la cultura.

-MV: El arte japonés fue fuente de inspiración para muchos artistas del siglo XIX y principios del XX, especialmente en aquellos rupturistas. La asimetría del arte japonés contrastaba con la usanza artística occidental y funcionaron como prácticas manumisoras de las convenciones de entonces... ¿Por qué crees que en la actualidad vuelve a impactar fuertemente la estética japonesa en el Diseño Occidental? ¿Esto lo ves también en el arte? 
-MG: Efectivamente, en la época del impresionismo fue muy fuerte la influencia del arte japonés.

-MV: ¿Por qué crees que esa influencia fue tan importante?

-MG: Porque el comercio de Japón estaba cerrado y se abrió en 1868. A partir de allí empezamos a trabajar con toda la traducción de los conceptos occidentales y a participar de la exhibición mundial. En ese momento, los occidentales comenzaron a conocer el arte japonés, especialmente los grabados ukiyo-e que influenciaron mucho al impresionismo, como así también la caligrafía. Lo vemos en las pinceladas, en los trazos. En la actualidad es muy fuerte esta influencia, ahora hay mucha gente que toma cursos de caligrafía, yo creo que el pintor argentino Eduardo Stupía trabaja mucho también con ese tipo de trazos.

-MV: ¿Crees que el sentido introspectivo y de interrelación entre el hombre y la naturaleza que se ve reflejada en la cultura japonesa es lo que impacta en la actualidad en occidente? Lo veo como una necesidad de búsqueda hacia un diseño más minimalista por parte de los occidentales. Algo que va más allá de lo puramente estético.

-MG: Sí, la imperfección o lo incompleto. Todo lo incompleto (que en occidente puede sonar como negativo) en Japón siempre existió. El arte del inacabamiento, que deja siempre un rincón vacío.

-MV: Y ese rincón vacío ¿que vendría a representar?

-MG: La posibilidad y un mundo infinito. Si llenas un espacio, se completa y se marca un límite. Si dejas un rincón vacío queda abierto.

Le pido que me de otro ejemplo del impacto del Zen en el diseño.

-MG: En la cerámica por ejemplo, se ve la influencia de lo japonés. Los alfareros occidentales contemporáneos trabajan de manera muy japonesa. Es decir, no ya con tazas blancas brillantes, sino con una estética más sobria.

-MV: Lo que dices me recuerda a lo que Tanizaki decía en El elogio de la sombra, ese maravilloso ensayo que explica la estética japonesa. Allí, el escritor expresa su manifiesta predilección por la vajilla de laca antes que la cerámica, si bien destaca que: "una vajilla de cerámica no es nada desdeñable, es cierto, pero a las cerámicas les faltan las cualidades de sombra y profundidad de las lacas" (Tanizaki, 2016, p. 35).

MG: Esto también se fue perdiendo por que nuestro país se occidentalizó. Hubo mucha modernización, hay una vuelta en la actualidad en Japón a volver lo clásico, a lo propio a lo rural.

-MV: Hoy se habla mucho de la identidad en América Latina y en Occidente en general. ¿Ustedes también sienten la necesidad de esa búsqueda de la propia identidad?

-MG: Sí, creo que sí. Fue muy fuerte el impacto del terremoto del norte en los japoneses. A partir de allí se vio una influencia en el arte de la cultura regional de cada uno. No sé si buscan la identidad japonesa, sino más bien la identidad del lugar de donde viene cada uno, más bien localista, de un pueblo o región. 
-MV: ¿Cómo lo ves desde lo filosófico?

-MG: Japón es un país insular, por su misma geografía, hay volcanes, siempre hubo terremotos, inmediatamente se producían incendios y siempre se perdía todo y se volvía a construir. Esto tiene que ver con el ciclo de las cuatro estaciones. La idea que una estación se va, pero después vuelve. Por esto del terremoto los japoneses, creo, volvieron a recordar esto de lo impermanentes que somos.

Seguimos hablamos del concepto de vacío. Pero luego le pregunto acerca de otros que están muy presentes en su cultura: el instante, la ambigüedad y la vulnerabilidad.

Le pido que haga referencia a esos conceptos vinculados al diseño, el arte la estética y a la filosofía.

La filósofa entonces vincula al concepto de instante directamente con la poesía Haiku. Para aclararlo recita una conocida poesía muy breve de (5, 7, 5 sílabas). Su voz resuena como un tintineo en las tazas de café del bar porteño donde se produjo el encuentro:

-MG: "El estanque antiguo

Salta una rana

El ruido del agua"

Tengo delante la copia de una vieja publicación que reproduce parte de una conferencia de Jorge Luis Borges llamada La Poesía del Japón que dictó en la Asociación Japonesa de la Argentina (imagino que sucedió a fines de los años setenta o principios de los ochenta), porque la misma carece de información precisa. Leo: (...) "parece que siempre los japoneses han sentido eso. Siempre han vivido en la idea de la brevedad" (s/f.) Luego, en otra página el mismo Borges continúa explicando el significado del concepto de instante:

Del estanque ha saltado una rana, sobre la gran campana se ha posado una mariposa. Hay ese instante. Ese instante vendría a ser como una revelación, un momento en el cual el sujeto, el yo, (el yo que según la filosofía budista es ilusorio), nuestra conciencia se identifica con la experiencia, y eso es ya poesía. Ahora sé que hay una relación, por lo menos siempre se afirma, entre el Budismo Zen y el Haiku... (Conferencia de Jorge L. Borges, La Poesía del Japón, s/f.).

Y luego, también refiriéndose al Haiku, Borges remata:

(...) esa poesía es del presente, de un presente que sí es precioso. Yo diría que esto es lo esencial del Haiku, por lo menos para este mero occidental que soy yo. El hecho de una poesía que sabe que el presente es precioso y que aprecia cada presente y que no piensa que eso se perderá y que eso formará parte del olvido. No, cada presente es precioso y es aceptado con gratitud. Y eso vendría a explicar el Haiku mejor que razones de orden fonético (...) es decir el goce del presente, el apreciar este presente. Ello vendría a ser una justificación. Y eso vendría a ser una justificación en el Budismo Zen y en el Haiku (Conferencia de Jorge L. Borges, La Poesía del Japón s/f.). 
-MG: Por ejemplo, la flor del cerezo que florece y enseguida se cae. Eso es efímero. Lo vemos como una forma de aceptación. No como algo negativo.

Respecto del concepto de ambigüedad, Goda explica que: "una taza rota no es fea sino que puede ser algo bello". Se rompe algo, la fisura se prepondera y hay una forma de resaltarlo que puede ser algo bueno, bello". Y aquí hace referencia al arte del kintsugi. Esta técnica implica reparar piezas rotas con materiales como el oro, platino o plata. La belleza reside en la originalidad de la misma y expresan su historia.

Durante una pausa de la entrevista y para ampliar el significado, leo al respecto en un artículo en la web que: “(...) entre sus principales influencias está el término estético wabi-sabi, que llama a ver la belleza en la imperfección, así como en los conceptos mottainai, que expresan lamentación cuando algo se desperdicia; y mushin, la aceptación del cambio" (Olguín, 2017).

-MV: Contrario a la mirada occidental, que busca la eterna juventud, la perfección.

En relación al concepto de vulnerabilidad, me advierte que ellos lo ven como una fortaleza, contrario a nuestra concepción occidental en la que la percibimos como debilidad.

Respecto de la ambigüedad, Goda explica que: "En la comunicación existe esta ambigüedad también. El japonés nunca dice No. Por eso a veces es difícil comunicarse con él” (Comunicación personal, 7 de diciembre de 2017).

-MV: ¿Por qué no dicen que no?

-MG: Para dejar pasar la situación. Para evitar el conflicto.

-MV: ¿Cómo sabe tu interlocutor que le están diciendo que no?

-MG: (risas) el otro tiene que adivinarlo.

-MV: Algo así como: L'ambasciator non porta pena

-MG: Sí, (ríe) eso exactamente.

-MV: ¿Cuál es la principal diferencia con el sentir estético occidental?

-MG: Si para la estética occidental -en el sentido de la regla de oro de los griegos- está dada por la simetría, la proporción y la perspectiva; para la japonesa es lo contrario: la asimetría, sin perspectiva, no se toma en cuenta la perspectiva.

-MV: ¿Cómo lo expresarías?

-MG: Creo que está vinculado con la naturaleza. Tiene que ver con la forma en que percibimos la naturaleza. Nosotros la vemos en capas [sic]: 70\% de la tierra en Japón es naturaleza: montañas y bosque (sin considerar las grandes ciudades). Antes si ibas a Japón a pasear era todo bosque. Insiste: "como en capas", no había una perspectiva, como ustedes que tienen la pampa, por ejemplo, eso te da una perspectiva. Esa apertura del paisaje que en Japón nunca hubo.

Hablamos de Tanizaki, de la arquitectura tradicional japonesa y de la búsqueda de la sombra “(...) por eso, cuando iniciamos la construcción de nuestras residencias, antes que 
nada desplegamos dicho tejado como un quitasol que determina en el suelo el perímetro protegido del sol, luego, en esa penumbra, disponemos la casa" (Tanizaki, 2016, p. 41).

Goda cuenta que actualmente en la arquitectura japonesa contemporánea hay mucha luz. Todavía en las zonas rurales se mantiene el estilo de la casa tradicional: con la puerta característica denominada shōji y sus marcos de madera y papel washi que funcionan como divisores. Lo vincula con la geografía y el clima más que con el pensamiento.

Mi mente vuelve al libro El elogio de la sombra:

Pero nosotros, no contentos con ello, proyectamos un amplio alero en el exterior de esas estancias donde los rayos el sol entran ya con mucha dificultad, construimos una galería cubierta para alejar aún más la luz solar. Y, por último, en el interior de la habitación, los shōji no dejan entrar más que un reflejo tamizado de la luz que proyecta el jardín. Ahora bien, precisamente esa luz indirecta y difusa es el elemento esencial de la belleza de nuestras residencias (Tanizaki, 2016, p. 43).

-MV: Los shōji, que dicho sea de paso, se pusieron de moda en la actualidad en el diseño de interiores minimalista en muchos países occidentales (por supuesto elaborados con otros materiales) ¿es algo que también se lo vincula al concepto de ambigüedad para ustedes? Por ejemplo, un pasillo puede ser un pasillo y luego transformarse en un cuarto.

-MG: Sí, exactamente. Este pasillo puede ser parte del jardín, pero también es como una terraza, o un balcón, como que pertenece afuera pero también es parte de un cuarto.

-MV: ¿En el diseño, es más bien funcional el concepto de ambigüedad?

-MG: Tiene dos sentidos. Esta parte es para protegerse de la lluvia y también funcional para que la gente pueda circular. La casa tradicional japonesa (como es muy húmedo Japón y hace mucho calor) está hecha pensando en los hombres dentro de un mundo rural.

-MV: ¿Qué sería un objeto bello para un japonés?

-MG: Un objeto que no es simplemente un objeto sino algo que vive, Por ejemplo, una taza, que la tocas para sentir el contenido.

Inevitablemente, para comprenderlo vuelvo a Tanizaki (2016):

Cuando sostengo en el hueco de mi mano un cuenco de sopa, nada me resulta más agradable que la sensación de pesadez líquida, de vívida tibieza que experimenta mi palma. Es una impresión análoga a la que produce al tacto la carne elástica de un recién nacido (p.35).

La conversación atraviesa naturalmente conceptos ligados a los sentidos y al diseño.

Para Goda, el diseño, no es solo visual, sino que lo vincula también con lo táctil. En relación al kimono sostiene:

Kimono es solo kimono [sic], sigue siendo algo tradicional. Hay jóvenes todavía en Japón que practican la ceremonia del té y disfrutan de ir a pasear por el 
jardín y se peinan al modo tradicional y lo siguen respetando como algo tradicional (Comunicación personal, 7 de diciembre de 2017).

-MV: ¿Hay algo que cuando ves una prenda de un diseñador japonés lo mires y digas “esto lo hizo un diseñador japonés"?

-MG: Sí, el pliegue, el corte, la forma que me hace pensar en el primer estado de la materia prima, papel o tela. Como muy simple, la bidimensión. Juega con el concepto de vacío entre el cuerpo y la tela.

En occidente la materia pierde su identidad para obedecer al cuerpo. En cambio en Japón tiene su propia forma la ropa. Por eso también es difícil llevarlo.

Reviso, busco y lo veo claramente en los diseños de Kunihiko Morinaga, de Anrealage; en Rei Kawakubo de Comme des Garçons; en Issey Miyake; sólo por mencionar algunos ejemplos.

-MV: ¿Cómo es ese vínculo entre la naturaleza y el diseño en oriente? ¿Cómo se manifiesta? -MG: La naturaleza está muy incorporada en el diseño. Por ejemplo en la comida, comes sushi y hay una decoración (por ejemplo hay una hoja de pino) que se hace de acuerdo a los elementos de la estación en que estás. Hay mucho vínculo entre los diseños y la naturaleza, en la moda quizás no tanto desde la forma pero sí desde los estampados. Hay muchos motivos decorativos que se inspiran en los elementos de la naturaleza. Lo ves también en los estampados del kimono.

-MV: ¿Cuánto es importante la materialidad de un objeto? ¿Es más importante que el diseño?

-MG: El diseño tiene la misma importancia. Pienso en los dulces japoneses que tienen formas de flores, elementos de la naturaleza. Creo que el diseño, la materia prima empleada tiene concordar con la naturaleza, no contraponerse. Se deben integrar.

(Esto concuerda con lo expresado por Tanizaki (2016) cuando hace alusión a que los colores del Yōkan, son de una complejidad difícil de encontrar en un dulce occidental)

-MV: Eso es muy de la cultura japonesa... pero, en la actualidad... ¿Sigue esa tradición? ¿Existe un vínculo con el Budismo?

-MG: Creo que hay, no digo en todo, pero hay gente que vive así. La filosofía está integrada a las costumbres, hay una mezcla. Es una forma de vida.

Los mismos jóvenes japoneses se sorprenden de la propia tradición y estudian el diseño clásico japonés, estudian mucho el diseño, la historia y la arquitectura japonesa.

-MV: Estamos en un mundo en transición (incertidumbre incesante por el futuro, tensiones, diásporas, migraciones masivas, agotamiento ambiental, etc.) ¿Cómo crees que están respondiendo ante esta situación artistas y diseñadores japoneses actualmente y cómo lo han hecho en el pasado?

¿Cómo crees que se podría ayudar en esta transición? ¿Crees que el diseño puede colaborar en un entendimiento entre los pueblos, mejorar la comunicación? 
-MG: Creo que hay una tendencia tanto en el arte y en el diseño como así también en la cultura en general de tomar conciencia de lo originario. Y de manifestarlo tanto en la forma como así también en la materia, con un ingenio en la adaptación pero sin perder las raíces. Pienso que ésta búsqueda es la única seguridad que tenemos en un mundo en transición: a partir de la idea de cómo es cada uno, cómo le gusta vivir: con cierta comodidad espiritual y corporal, es pensar en el clima y el ámbito que nos rodea. Es una forma de reconciliarse, o estar en armonía con su propia vida. Diseñar es un poco como crear el propio refugio que ofrece una sensación de seguridad.

\section{Comunicación, diseño, blanco y vacío}

El diseñador japonés Kenya Hara en el prólogo de su libro White (2017) explica el vínculo de varios de los conceptos analizados a lo largo de este escrito y aclara que si bien su trabajo es el de diseñar, su campo profesional es el de las comunicaciones. Explica que ilustra circunstancias o condiciones más que cosas. Para él, el vacío (utsu) y lo completamente hueco (karappo) son algunos de los términos que consideró al tratar de comprender la naturaleza misma de la comunicación.

Esto resulta esencial para comprender que el arte del lenguaje japonés, está indisolublemente vinculado al diseño y a su filosofía. Para un japonés hablar y escuchar es un verdadero arte. Hara (2017) ejemplifica ese instante blanco-vacío como el momento justo antes de que comience una actuación de música o danza. Al respecto, insiste en que se asemeja al de la pureza de la hoja en blanco, lo define como un estado de tabula rasa, tanto para la audiencia, como para el intérprete.

Para el japonés, el vacío es posibilidad. Por ello, tanto la comunicación como las ideas emergen del vacío.

Respecto del vínculo de la cultura japonesa con la naturaleza, la creación y la filosofía Zen, algunos autores como Hara (2017) consideran que la sensibilidad japonesa probablemente esté más en sintonía con la conservación que con la novedad. En sus mismas palabras: "No me refiero a que los japoneses no sean creativos, sino creo que la innovación proviene de esa conciencia que trata de mantener las cosas tal como son. El poder de la transformación no es algo nuevo" (p. 70). Es decir, así como la naturaleza se modifica constantemente, se requiere mucha energía y armonía para preservar las cosas bellas, de modo que es fundamental observar esa transformación muy de cerca, para capturar su quietud mientras se defienden sus características inmutables y universales.

Como se ha podido observar, la filosofía impregna el diseño japonés y vincula cada uno de los conceptos analizados. El diseño japonés es vida, filosofía, arte, estética e innovación en estado puro. Puro como el blanco. En palabras de Hara (2017) "la simplicidad lleva al vacío, el espacio donde reside la mente de las personas, como hemos visto, es el origen de la comunicación y se refleja en cosas como el mito japonés" (p. 55).

\section{Bibliografía}

Borges, J. L. (1993). Siete Noches. Madrid: Fondo de Cultura Económica 
La Poesía del Japón Asociación Japonesa de la Argentina (s/f ).

Embajada de Japón en la Argentina, 2018. Recuperado de: http://www.ar.emb-japan.go.jp/ itpr_es/RelacionesBilaterales.html

Hara, J. (2017). White. Zürich: Lars Müller Publishers.

JVT 2006.7 -- Furoshiki the Flexible Wrapping Cloth. Recuperado de: https://www.youtube. com/watch?v=ERT_WSr0o3M

Olguin, B. "Farenheit Magazine", El arte japonés del 'Kintsugi' o la belleza de lo imperfecto 2 de agosto de 2017. Recuperado de: http://fahrenheitmagazine.com/cultura/centenarioarte-japones-kintsugi-belleza-imperfecto/

Shimizu, C. (1984). El arte Japonés. Buenos Aires: Paidós.

Tanizaki, J. (2016). El elogio de la sombra. Madrid: Siruela.

\begin{abstract}
Given the growing interest in Japanese culture in Argentina, this essay attempts to analyze the link between the concepts of moment, emptiness, ambiguity and vulnerability, to relate them to design, art, aesthetics, Zen philosophy and nature. The kimono, the characteristic door called shōji, its wooden frames and washi paper, Haiku poetry, white and shadows, are some of the examples that are addressed to explain it. It is also essential to understand that Japanese language is also inextricably linked to design and its philosophy. In Japanese culture, speaking and listening is a true art and the reason why this paper addresses the issue from not only the texts of Kenya Hara, Junichirō Tanizaki and Jorge Luis Borges, but also includes -necessarily- a dialogue between the author of this article and the Japanese philosopher Mami Goda, resident in Argentina for almost a decade.
\end{abstract}

Keywords: Japanese culture - emptiness - moment - ambiguity - vulnerability - design art - Zen philosophy - Haiku- kimono.

Resumo: Dado o crescente interesse pela cultura japonesa na Argentina, no presente ensaio tenta analisar a ligação entre os conceitos de instante, vazio, ambiguidade e vulnerabilidade, relacioná-los com design, arte, estética, filosofia zen e natureza. O quimono, a porta característica chamada shōji, seus quadros de madeira e papel washi, a poesia Haiku, branco e sombras, são alguns dos exemplos que são abordam-se para explicá-lo. Também é essencial entender que a linguagem japonês está intrinsecamente ligado ao design e à sua filosofia. Para um japonês falar e Ouvir é uma verdadeira arte. É por isso que o resumo aborda a questão não apenas dos textos do Quênia Hara, Junichirō Tanizaki e Jorge Luis Borges, mas também inclui-necessariamente- um diálogo entre o autor deste artigo e o filósofo nipona Mami Goda, residente na Argentina há quase uma década.

Palavras chave: Cultura japonesa - vazio - instantâneo - ambigüidade - vulnerabilidade design- arte - filosofia Zen-Haiku-kimono.

[Las traducciones de los abstracts fueron supervisadas por el autor de cada artículo] 
Resumen: Elaborando sobre conceptos del lenguaje como elemento que construye, constituye, forma y determina valores personales y sociales, este artículo cuestiona ideas en cuanto a la producción creativa y su relación con procesos sustentables de empatía. Adoptando una mirada de auto reflexión sobre la base de elementos presentes en la producción de la obra de la autora, como diseñadora de Indumentaria y artista plástica, se pone en evidencia la tensión y conflicto entre sentimientos de dislocación y su relación con intereses teóricos que han informado los procesos creativos de la autora. Una exploración teórica a su producción creativa como inmigrante Latina en Nueva Zelanda y el desplazamiento en cuanto a su autopercepción informan la base de este escrito.

Palabras clave: lenguaje - empatía - sustentabilidad - inmigración - tensión - conflicto.

[Resúmenes en inglés y portugués en las páginas 36-37]

${ }^{(*)}$ Graduada en la Universidad de Auckland, Nueva Zelanda con una Maestría en Bellas Artes; Licenciatura en Bellas Artes con especialización en Diseño de Indumentaria, Whitecliffe College of Art and Design, Nueva Zelanda; Certificado en Comunicación en Moda, London College of Fashion, Inglaterra. Docente en el Departamento de Diseño de Moda en la carrera de grado y Maestría, Whitecliffe College of Art and Design, Nueva Zelanda. A lo largo de su trayectoria se desempeñó como artista plástica en el área de moda y textiles, trabajo como diseñadora, compradora de indumentaria, jefa de prensa y productora de moda en diferentes empresas en Argentina y en Nueva Zelanda.

\section{Introducción}

La indumentaria establece relaciones íntimas con el usuario. La tela que usamos para vestirnos, la tela que rodea nuestros cuerpos y está en contacto con nuestra piel genera diferentes reacciones. Por un lado, se genera una reacción física que tiene que ver con la sensación que genera el contacto de nuestro cuerpo con el material; pero también se genera una reacción más íntima en cuanto a la autopercepción del usuario al vestirse con un material en particular. A efectos del presente artículo partiremos de la premisa que la indumentaria es una extensión de nuestra piel y se ubica en el borde de lo que percibimos como el yo y el otro. El espacio entre la indumentaria y el cuerpo es un espacio que no es 
un objeto consciente y en este preciso espacio es donde vuelco mi interés en relación con la indumentaria en general.

Adoptando una mirada de auto reflexión sobre la base de elementos presentes en la producción de mi obra como diseñadora de Indumentaria y artista plástica, es mi intención poner en evidencia la tensión y conflicto entre mis sentimientos de dislocación y su relación con mis intereses teóricos que han informado mis procesos creativos. Una exploración teórica a mi producción creativa como inmigrante Latina en Nueva Zelanda, el desplazamiento en cuanto a mi autopercepción e identidad y su reconstrucción informan la base de este escrito.

Elaborando sobre conceptos del lenguaje como elemento que construye, constituye, forma y determina valores personales y sociales, es que el trabajo de Julia Kristeva pasa a ser parte fundamental del contexto teórico de mi obra, del proceso creativo y su relación con procesos sustentables de empatía. Empatía por el observador, empatía por el usuario, pero principalmente empatía por el proceso mismo. Este proceso que lo entiendo como sustentable y que me ha comprometido en el ámbito de la indumentaria por dos décadas, lo defino como una actividad que desarrollada indefinidamente a través del tiempo no produce daño ni al medio ambiente ni a las personas que la practican (Fletcher, 2014, p. 2-3). Un proceso de empatía que ha evolucionado a través de mi obra y que ha acompañado mi proceso de inmigrante y mi proceso de asimilación a una cultura nueva y extraña.

\section{Obra - Lenguaje - Conflicto}

Mis experiencias como inmigrante latina en Nueva Zelanda han tenido un gran impacto en cómo me relaciono con mi obra y con mi proceso. Esto ha generado un cambio en cuanto a mi autopercepción que sigue vigente a medida que continúo transitando e interactuando en una sociedad que fue ajena y que continúa siéndolo luego de más de veinte años de residir en Nueva Zelanda. Formación, construcción y constitución del sujeto se han vuelto parte fundamental de mis intereses teóricos desde que deje mi país de origen, Argentina. La interacción con diferentes culturas ha puesto claramente en evidencia que cada lugar tiene normas y estructuras específicas de comportamiento que producen y generan valores en relación con ese lugar. El hecho de saber el lenguaje del lugar no significa que se entiendan las sutilezas culturales expresadas verbalmente a través del lenguaje o que el sujeto pueda participar del contrato social que lo rodea. El lenguaje no son palabras que combinadas entre sí generan un significado estático en cada lugar a través del tiempo (Barthes, 1957, p. 223) y se destaca firmemente la existencia de un proceso de significación que opera en diferentes lugares con significados diferentes, incluso al utilizar el mismo lenguaje.

Mi situación como inmigrante latina en Nueva Zelanda me señala claramente que tener buen dominio del idioma Inglés en un país de habla inglesa no implica que se entienda el significado cultural y sutil del idioma en operación. Al encontrarme en una situación en la que soy una extraña al proceso de comunicación de mi país de adopción se generan sentimientos de insuficiencia, un trastorno de mi autopercepción y un cambio en mi auto representación en el proceso de relacionarme con el otro. 
En Revolution in poetic lenguage, Julia Kristeva desarrolla la relación entre el sujeto y el lenguaje analizando la zona en la que se superpone el lenguaje con el psicoanálisis. Kristeva explora la ambivalencia del sentido que percibe el sujeto durante el proceso textual a través de los órdenes Semiótico y Simbólico. En el modelo que Kristeva propone, estos dos órdenes son inseparables en el proceso de significación que constituye la base del lenguaje y permiten diferentes clases de discursos en relación con el juego e interacción entre los mismos (1973, p. 23-92).

Elizabeth Grosz explora las escrituras de Kristeva y manifiesta que el orden Semiótico y Simbólico son dos órdenes inconfundiblemente diferentes, pero inherentemente relacionados entre si en el proceso de formación del sujeto, el cual no se ha constituido todavía. A través de su desarrollo, las pulsiones del simbólico serán ordenadas y relacionados entre sí (1989, p. 44). La Chora semiótica se relaciona con la formación del sujeto, donde la madre juega un rol definitorio como el principio que ordena. La relación entre madre y niño es el punto de partida en la cadena de significación a la cual el sujeto es introducido.

Kristeva define la Chora Semiótica como la simbiosis entre madre y niño, donde el cuerpo de la madre actúa como mediadora de las reglas y estructuras del orden Simbólico. La Chora actúa a través de pulsiones, energía que se mueve a través del cuerpo del sujeto, el cual no estructuradas a través del cuerpo. El proceso Semiótico será mediado a través de estructuras sociales, es decir, a través del orden Simbólico. El rol de filtro e interacción del orden Simbólico es innegable en este proceso ya que los mediadores del principio que ordena son generados a través del orden Simbólico. Por lo tanto, Kristeva afirma que la organización social, siempre como parte del orden Simbólico, marca sus restricciones en el sujeto a través de su constitución (1974, p. 35-36).

Si el orden Simbólico se relaciona en el proceso de significación, se deduce que el Simbólico es un lugar en el cual el proceso de significación tiene lugar a través de una estructura lingüística o proceso textual la cual moldea y modera una identidad subjetiva y social. El sujeto se construye, se produce y se moldea a través de la relación entre el Semiótico y el Simbólico. Un orden no puede existir sin el otro, sin embargo, el Semiótico está subordinado al Simbólico en el cual se imponen las estructuras lógicas del lenguaje. En el modelo de Kristeva el Lenguaje se define como parte estructural del orden Simbólico y a la vez parte de la constitución de la subjetividad. Pero el punto interesante que expresa Kristeva, es que el lenguaje tiene el potencial de generar un sujeto en crisis a través de la poesía, revelando grietas en el lenguaje que son representaciones de fisuras que el Semiótico abre sobre el Simbólico. Un sujeto en crisis, que linda con la locura, que atraviesa esas experiencias límites que abarcan la abyección, el horror, el amor, el exilio o la extranjería. Por otro lado, estas rupturas tienen el potencial de generar transgresiones, permitiendo infiltrar jouissance (1974, p. 44) en el ámbito social, que de otra manera estaría negado por el Simbólico. Estas rupturas o fisuras tienen la habilidad de generar una crisis, una explosión en la subjetividad. La poseía, el texto opera al nivel del signo, rechazando la unidad estructural y creando un sentido de placer extremo. Kristeva considera el arte y la poesía como medios para infiltrar las estructuras del Simbólico, y aclara que son Semiotizaciones del Simbólico que representa jouissance en el Lenguaje (Kristeva, 1974, p. 39-59).

Como artista plástica y diseñadora de indumentaria este modelo genera un interesante dilema. Si el arte funciona como un elemento que revela grietas en la trama de la estructura 
social, el arte está situado en las afueras del borde estructurales de nuestra comprensión. Por lo tanto, surgen preguntas: ¿Como opera el Arte?; ¿Desde qué lugar crean los artistas afuera de los límites de su propia constitución? Y, finalmente, ¿Como se involucra la indumentaria como proceso de comunicación visual en un potencial medio de transgresión? Estas preguntas originaron extremo debate interno en cuanto a ideas ambiguas y contradictorias de como abarcar mi propia obra. ¿Cuáles son los límites y bordes del arte y de la producción creativa? ¿Como los podemos transgredir? ¿Como podemos extender y desafiar los límites de nuestro proceso creativo?

Kristeva sugiere que, a través de la expresión poética, el Lenguaje problematiza la subjetividad dándole expresión Simbólica al jouissance del Semiótico; destruyendo lo que ha creado. A la vez, le da al sujeto la posibilidad de transmitir, recibir o deformar el significado del discurso (1974, p. 39-59). En este contexto, se entiende que el sujeto puede transgredir o interrumpir el orden socio simbólico a través de la alteración de la estructura del Lenguaje. Esto presenta un peligro para con el sujeto ya que este se encuentra lidiando con elementos inherentes a su propia constitución y puede entrar en crisis.

Mi interés se genera a partir de este punto, en el cual el sujeto tiene el poder de transgredir su propia construcción subjetiva. Esta intervención genera oportunidades potenciales realmente transformadoras dentro del campo artístico.

Como inmigrante y extranjera en Nueva Zelanda, me encuentro con sentimientos de dislocación, de no pertenecer, una extranjera en la sociedad en la que vivo, sin entender los mecanismos implícitos en el comportamiento social local y una sensación de que mis valores y principios son muy diferentes de los de la gente que me rodea cotidianamente. La Revolución del Lenguaje Poético resuena conmigo a un nivel muy personal y plantea la pregunta acerca de si existen varios procesos de significación operando a diferentes niveles y si esto me da la posibilidad como creadora de transgredir el orden social de una manera diferente, desde un punto de vista diferente, como extranjera al orden Simbólico que me rodea pero que lo percibo como extraño y no familiar.

De esta línea de pensamiento es que surge la necesidad interna de trabajar con mi propio contrato social, mi propia subjetividad y el lugar que establece el Lenguaje en mi propia constitución. Mi premisa, por lo tanto, es que el Lenguaje actúa como elemento inherente en la constitución de mi subjetividad, y esta constitución es particular a mi lugar de origen, a mi país y a las leyes sociales en operación al momento en el que fui criada. Esta mirada me ha dado la oportunidad de mirar hacia atrás con relación a mi subjetividad y su interacción con el Lenguaje como elemento que construye y me ha permitido una travesía de auto análisis e introspección al evaluar la documentación de mi existencia material y psicológica. Cuadernos del colegio primario, lecciones, dictados, substracciones, ¡Muy bien! ¡Muy mal, ¡Excelente! Estándares de bien y mal, lo correcto, lo apropiado, lo no correcto y lo no apropiado dentro de la política del comportamiento social. Orden Simbólico. Diarios secretos de mi etapa adolescente, percepciones de mi ámbito, miedos y ansiedades. Memorias, melancolía, mis memorias, momentos pasados, el pasado, mi historia. Orden Simbólico una vez más.

A través de mi obra creativa comenzó una etapa de cuestionamiento de estas prácticas codificadas que operan del ámbito de la sociedad, explorando sus límites, sus bordes y fronteras con el orden Semiótico. Comenzó un proceso de desplazamiento de mi documentación y su lugar asignado en el orden Simbólico, sacándolos de contexto, creando 


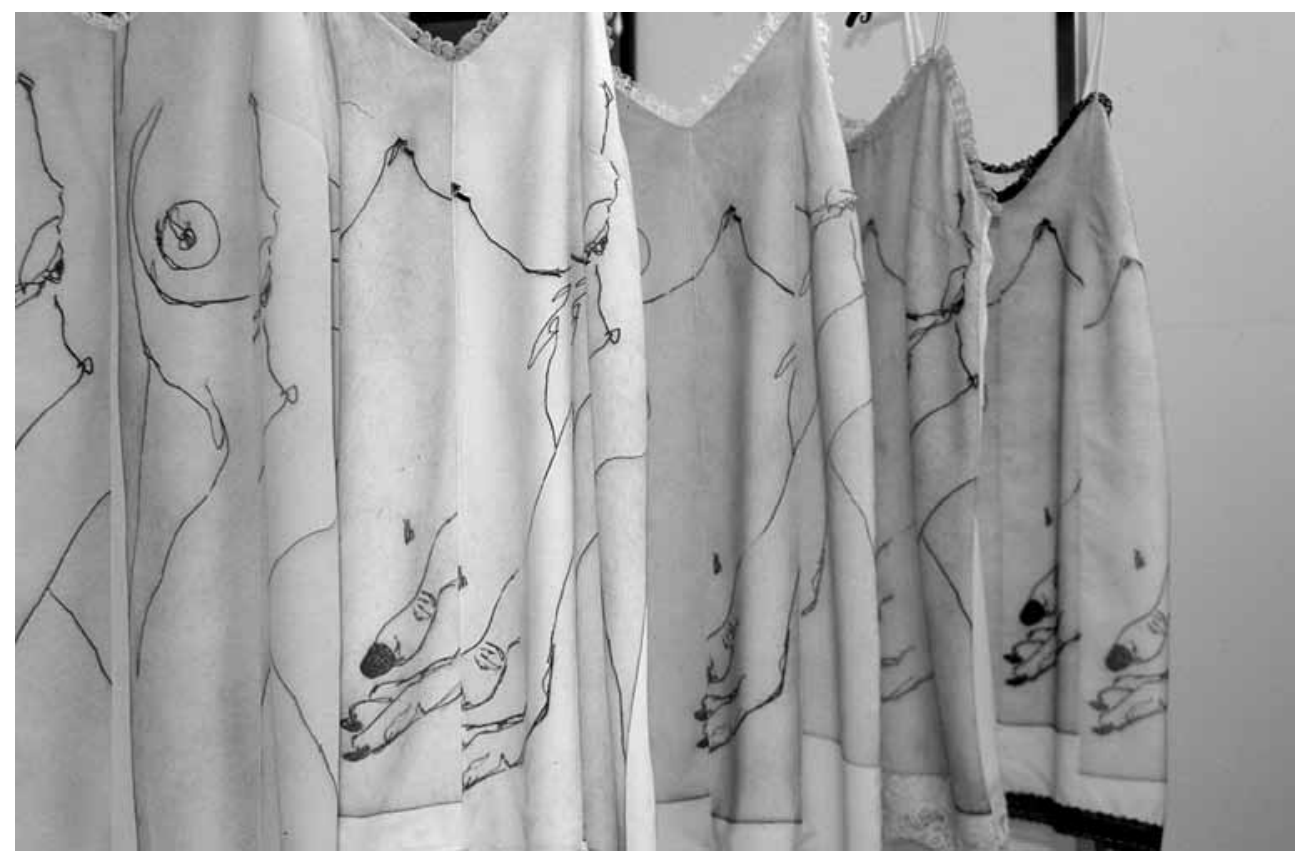

Figura 1. Cuerpos monstruosos, cuerpos grandes, cuerpos vacíos, cuerpos que cuelgan.

situaciones inesperadas a través de la forma, alterando la calidad del signo. El resultado de esta alteración, esta dislocación, transgresión o subversión se puede leer como aquel que actúa a un nivel similar al cual Kristeva se refiere como el espacio en el que el orden Semiótico desborda al orden Simbólico.

A pesar de que me encuentro trabajando dentro del orden Simbólico y mantengo mi estado de sujeto constituido a través del Lenguaje y desde dentro de la estructura misma del proceso textual durante todo el proceso creativo, se produce una inconfundible sensación de desplazamiento, un cambio en mi auto percepción. Mi obra, mi trabajo es la representación de mi propio desplazamiento, con lo cual no se relaciona con el orden Semiótico a través de su proceso de creación, sino que lo hace a través de la representación de mi experiencia de una subjetividad en crisis. A otro nivel, esta relación presenta un interesante problema ya que la representación de mi propia dislocación y desplazamiento podría ser percibida por el observador, el cual es ajeno a la obra, desde su punto de vista centrado desde el orden Simbólico. A través de mi obra he planteado que la universalidad del cuerpo femenino me permite romper ciertas barreras en términos de cultura y socialidad para poder entablar un proceso innovador de interacción con el mundo que se percibe (Ver Figura 1). 
A través de construir y re construir las imágenes de mis auto percepciones en forma de dibujos y bosquejos monstruosos, se desarrolló la instalación "Documento". Forzando mis imágenes mentales monstruosas y gigantescas en un talle 12 de mujer me permitió adaptar monstruosidad en estereotipo y al presentar la obra través del método de instalación me dio la oportunidad de crear objetos reconocibles como vestidos femeninos y delicados dentro del ámbito de lo que el observador reconoce como Moda, la cual se encuentra dentro del contexto y orden Simbólico y social.

Estos cuerpos colgantes y desagradables generados a partir de mi lugar de inmigrante en una sociedad ajena a mí relacionan mi obra con lo que Julia Kristeva denomina abyección (1980, p. 229-235). En Powers of Horror, Kristeva elabora en el ámbito de las experiencias límites y las clasifica como formas y espacios que ponen al sujeto en crisis. El asco, el dolor, la impureza y el horror son parte del abyecto. Si bien el proceso que concluye con mi obra es una travesía que corta a través de mi identidad, la procesa, la elabora y la reproduce con un formato particular, es un proceso de empatía. Empatía hacia la persona que crea, empatía hacia el observador, pero por sobre todo empatía hacia el conflicto y tensión que se producen en las grietas de la identidad cuando el sujeto migra desde su lugar social hacia lo desconocido.

\section{Reconstrucción}

La dedicación al proceso creativo generado a través de la empatía generó un lugar de observación y reflexión hacia el medio ambiente en el cual me encuentro. En mi caso, la lucha por preservar mi identidad quebrada a raíz de mi migración, generaron intereses cada vez más locales en Nueva Zelanda. Con el deseo de echar raíces en mi nueva ubicación geográfica a través de mi trabajo es que comenzó una etapa de observación, clasificación y admiración de los materiales locales, propios al ambiente que habito. Materiales como la lana, tintes naturales, el harakeke (planta de lino) surgieron como elementos propios de este lugar con su historia y su simbología. El valor sagrado que se le da al hilado dentro de la estructura social de los pueblos originarios de la región del Pacifico ha contribuido a la supervivencia de prácticas textiles sustentables y tradicionales de estas culturas y está presente en las prácticas culturales actuales de Nueva Zelanda.

En el libro Pacific Pattern, Susanne Kuchler and Graeme Were sugieren que la naturaleza sagrada del hilado y su relación con rituales y mitos está muy presente en las culturas del Pacifico. En los tejidos de la cultura Maorí, por ejemplo, las tejedoras utilizan las mismas técnicas y materiales naturales que usaban sus ancestros. Utilizando sus manos como herramienta principal, las tejedoras traman y urden las fibras del harakeke de manera intrínseca y compleja mostrando un gran respeto por el material utilizado que posee propiedades espirituales, Mauri (2005, p. 63).

Desde la cosecha hasta el tejido, el proceso tiene un protocolo a seguir. En el caso del harakeke (lino de Nueva Zelanda, Phormium tenax), que es la planta más común y versátil en el tejido Maorí, la recolección comienza con una Karakia (oración). Mucho amor y cuidado entra en el proceso de cosecha y la selección de la variedad apropiada de harakeke es particularmente importante. Una vez que el tejedor ha seleccionado la planta adecuada, 
las hojas se cosechan. Hay algo muy especial acerca de este proceso de selección y cosecha. Es en este mismo momento del proceso cuando la relación entre las tejedoras, los antepasados de la tierra y el conocimiento de la cultura, es más relevante. Las tres hojas centrales de la planta que se llaman te rito (hoja central o niño) y te awhi rito (a ambos lados del niño), son las más cuidadas. No se deben cortar ya que representan a la madre, al padre, que rodean y protegen al niño, como la próxima generación de la planta del harakeke. Las siguientes tres hojas a cada lado de las tres centrales se cortarán en un ángulo particular para evitar que la lluvia cause daño al harakeke. Las tejedoras solo cortarán lo que se necesita y siempre limpiarán alrededor de la planta para promover la buena salud y la conservación de este material precioso. A partir de este momento, el proceso continúa e involucra no solo las manos de las tejedoras, sino todo su cuerpo, mientras que $M u k a$ se extrae del harakeke (Whiria, 2015, p. 41). La tejedora participa en esta transformación de planta, a fibra, a hilo; respetando, adorando y celebrando su propia cultura y creencias mientras manipula el hilo sagrado que se convertirá en una tela sagrada. Las canciones y dichos usados en Aotearoa (Nueva Zelanda) refuerzan estos elementos para muchos propósitos, por lo que estas ideas no se limitan al proceso de tejido, sino que se recuerdan y se vuelven a usar para muchos eventos culturales y no culturales, incluidas las asignaciones para otros fines.

Pero la estructura social sagrada del hilado no está solamente presente en la zona del Pacífico. Del mismo modo, en el otro lado del mundo, en el altiplano peruano, Nilda Callanaupa Alvarez, una tejedora de Chinchero, Perú, se refiere a la tela producida por su comunidad indígena en términos similares. Ella habla de una tela que se hace hilo a hilo, de las manos de su gente. Una tela que está viva y es un reflejo del espíritu del creador y afirma que ha aprendido que cada pieza de tela representa el espíritu, la habilidad y la historia personal del tejedor. Tejer es un arte vivo, una expresión de cultura, geografía e historia (Callanaupa, 2007, p. 1).

Mis observaciones en cuanto a los atributos del hilado dan cuenta de mi proceso y confirmaron que el vínculo entre el hilo, la geografía y la cultura es de extrema importancia en un intento de comprender el valor adjunto a este hilo sagrado. La tejedora es vista como el vínculo entre el conocimiento ancestral, la tierra y la creación. La tela producida por este hilo sagrado no es cualquier tela, es una tela con valor intrínseco y propiedades culturales. En su libro The andean science of weaving, Elvira Espejo y Denise Arnold comentan sobre este mismo punto y afirman que la naturaleza de lo textil como ser vivo tiene que ver con su corporeidad y tridimensionalidad. Afirman que el textil emergente es considerado como un bebé en su propio camino hacia el nacimiento y que los tejedores piensan que este ser viviente come y digiere las sustancias nutritivas introducidas en el espacio del tejido con cada paso de la trama (2015, p. 25).

La creencia de que los textiles no son objetos pasivos sino seres interactivos coloca a las tejedoras en una posición de importancia significativa y como parte vital de las propiedades multidimensionales del textil. La tejedora no solo teje, sino que también participa en la etapa posterior al tejido, en la distribución del conocimiento a través de su obra.

La apreciación por el hilado sagrado me ha permitido abordar mi obra desde un lugar que se afirma al pasado, pero a la vez hace uso de los recursos materiales que encuentro en mi lugar de adopción. Tintes naturales de la zona que habito se mezclan con tintes oriundos 
de mi patria y se trama una tela de memorias que transitan por lugares oscuros e inesperados de mis experiencias como inmigrante.

Luego de dos décadas de proceso creativo afuera de mi lugar de origen, y de proceso de identidad en evolución que reconstruye a través de materiales propios de mi nuevo lugar y con una psicología propia de mi lugar de origen; sugiero que la calidad del proceso creativo debe estar siempre informada por el proceso de formación de identidad y su relación con las estructuras sociales que nos rodean. El entender el pasado nos permite entender la universalidad de los procesos materiales y culturales y el imaginar el futuro nos permite centrarnos firmemente en cualquier espacio geográfico en el que nos encontremos.

\title{
Bibliografía
}

Arnold, D. \& Espejo, E. (2015). The Andean Science of Weaving. New York, NY: Thames \& Hudson.

Barthes, R. (2012). Mythologies. New York, NY: Hill and Wang. (Texto original 1957).

Callanaupa Alvarez, N. (2007). Weaving in the Peruvian Highlands. Cusco, Peru: Centro de textiles tradicionales de Cusco.

Fletcher, K. (2014). Sustainable Fashions and Textile, Design Journeys. New York, NY: Routledge. Grosz, E. (1989). Sexual Subversions. NSW, Australia: Allen \& Unwin.

Kuchler, S. \& Were, G. (2005). Pacific Pattern. London, England: Thames \& Hudson.

Kristeva, J. (1974). Revolution in Poetic Language. En Oliver, K. (Ed.). The Portable Kristeva. (1997). New York, NY: Columbia University Press.

Kristeva, J. (1980). Powers of Horror. En Oliver, K. (Ed.). The Portable Kristeva (1997). New York, NY: Columbia University Press.

Rotorua Museum Te Whare (2015). Whiria, Weaving global connections. Rotorua, New Zealand: Rotorua Museum Te Whare.

\begin{abstract}
Elaborating on the concept of language as an element that constructs, constitutes, shapes and determines personal and social values, this article questions ideas regarding creative production and its relationship with sustainable processes of empathy. Using self reflection as a tool to explore the elements present in the production of the work of the author, as a fashion designer/ textile artist, this article highlights the tension and conflict between feelings of dislocation and their relationship with theoretical interests that have informed the creative processes of the author. A theoretical exploration of her creative production as a Latina immigrant in New Zealand and the displacement in terms of her self-perception informs the basis of this writing.
\end{abstract}

Keywords: language - empathy - sustainability - immigration - tension - conflict.

Resumo: Elaborando conceitos de linguagem como um elemento que constrói, descreve, molda e determina valores pessoais e sociais, este artigo questiona idéias em relação à 
produção criativa e sua relação com processos sustentáveis de empatia. Adotar um olhar de auto-reflexão baseado nos elementos presentes na produção da obra da autora, como designer de roupas e artista plástica, ela se coloca em evidência a tensão e o conflito entre sentimentos de deslocamento e sua relação com interesses teóricos que informaram os processos criativos do autor. Uma exploração teórica para sua saída criativa como um imigrante latino na Nova Zelândia e deslocamento em relação à sua autopercepção, eles informam a base dessa redação.

Palavras-chave: Linguagem - empatia - sustentabilidade - imigração - tensão - conflito.

[Las traducciones de los abstracts fueron supervisadas por el autor de cada artículo] 



\section{La permanencia en el cambio. El poncho como bandera de libertad}

Ximena González Eliçabe *

Resumen: El poncho ha sido desde tiempos remotos un elemento presente, un objeto imprescindible en la vida cotidiana del hombre americano. A través de los siglos y con distintos aportes culturales se ha convertido en símbolo de nuestra identidad.

Participó de la historia de las Naciones de América del Sur, tanto desde las Misiones Jesuíticas donde se producían para comercializarse, como en tolderías y fortines, donde brindaban protección y abrigo.

El poncho fue protagonista de una floreciente industria textil en la Argentina a comienzos del siglo XIX. Al estudiar la producción de materias primas y manufactura de estos textiles, así como las rutas comerciales desde los centros productivos hacia las metrópolis, se comprenden aspectos sociales y económicos de épocas que consolidaron la construcción de la República, acrecentando la identidad nacional.

Actualmente aparece en las más importantes pasarelas internacionales y la moda en la calle también da testimonio de su aceptación como tendencia. Jóvenes diseñadores argentinos se proyectan en el mundo del diseño global, orgullosos de su identidad, incorporando ponchos en sus colecciones, con materias primas y tejidos novedosos, buscando nuevos usos posibles para esta tipología que no reconoce rubros ni protocolos.

Palabras clave: cultura - identidad - historia - República - economía - política social evolución - tendencias - diseño.

[Resúmenes en inglés y portugués en la página 50]

${ }^{(*)}$ Diseñadora Textil (UBA). Artista e investigadora de las tradiciones textiles americanas. Es Profesora de la Universidad de Palermo en el Departamento de Diseño de Modas de la Facultad de Diseño y Comunicación. Es consultora y capacitadora en temas de diseño y artesanía, trabajando en programas de instituciones públicas como el Ministerio de Turismo de la Nación, el Consejo Federal de Inversiones y otras. Realizó exposiciones y obtuvo diversos premios y menciones. Es directora académica del Centro de Estudios Latinoamericanos La Abadía, Bs. As. Curó la muestra "Ponchos en el Bicentenario", en el Museo de Arte Popular José Hernández, Bs. As. Es Directora de contenidos de ArgentinaXplora. com. En su actividad en la Universidad de Palermo publicó: Arte, Diseño y artesanía. La metáfora textil como signo de identidad (2005), Experimentación, innovación, ciencia y diseño (2006), Diseño, educación y preservación del patrimonio cultural (2006), Introspección, el cuerpo (2009). Arte Textil y Tradición en la Prov. de Catamarca, Noroeste argentino (2012). 
Arte sartorial, de lo ritual a lo cotidiano (2013), El Tiempo y la materia, atributos del nuevo lujo (2016).

El poncho ha sido desde tiempos remotos un elemento presente, un objeto imprescindible en la vida cotidiana del hombre en América del Sud. A través de los siglos y con distintos aportes culturales se ha convertido en símbolo de nuestra identidad.

El contexto en el que esta prenda se afianza y se difunde en América incluye diversos factores, varios de los cuales aún continúan presentes entre las preocupaciones sociales y políticas de nuestros tiempos, como, por ejemplo, la inmigración; diásporas; aumento de nacionalismo; y la disparidad económica.

Para esta publicación se nos pidió examinar, cuestionar y proponer nuevas miradas sobre el estado global de flujo o transición del mundo en que vivimos. A través de esas reflexiones surge la pregunta: ¿Cómo se reflejan en la historia estos momentos inciertos de transición en el arte y en el diseño?

Es por eso, que me propuse encontrar un hilo conductor entre los diferentes momentos de la producción textil y los hechos históricos y sociales relevantes que dieron por resultado la amalgama cultural de la Argentina de finales del siglo XIX y principios del siglo XX.

Nuestro país y Estados Unidos de América son repúblicas que nacen poco tiempo después de la Revolución Francesa. Su organización política como naciones del Nuevo Mundo, su conformación social, a partir de ciudades productoras de materias primas en grandes territorios; habitadas por nativos, colonos e inmigrantes de diferente origen y religión. El deseo de sus líderes de vivir en paz y libertad, aunque haya costado tiempo y sangre conseguirlas, es otro de los factores comunes. Este paralelo, tiene la intención de adentrar al lector en una época en donde las identidades nacionales se fueron forjando.

En estos procesos, las artes y el diseño suelen ser los elementos que aglutinan las características comunes, evidencian las costumbres y usos populares, los elevan a un estatus reconocido a través del tiempo y la memoria colectiva.

Desde la literatura, previamente al siglo XVIII aparecen crónicas como las de Ulrico Schmidl, y recién en el siglo XIX grandes obras de la literatura gauchesca como el Santos Vega (1885) de Rafael Obligado o el Martín Fierro (1872) de José Hernández, así como el poema épico La cautiva (1837) de Esteban Echeverría. En el teatro, en la pintura, se retratan personajes, batallas y costumbres. En la música y las danzas se encuentran elementos de origen clásico occidental y prehispánico, con la influencia africana que hace su gran aporte al tango y el jazz a mediados del siglo XIX. En el diseño de muebles se fusionan los estilos europeos con los motivos y materiales disponibles en América. En la indumentaria de las clases urbanas hay muy pocas diferencias con las modas europeas, pero en la áreas rurales, donde las mercancías del exterior no abundan y deben procurarse su propia producción de insumos, las cosas son diferentes.

Gran parte de la población del interior de Argentina se dedicó a la labor textil, ya sea para autoabastecerse o para comercializar. El caso es que numerosas familias criollas y mestizas de provincias como Santiago del Estero, Catamarca, La Rioja, Tucumán, Salta, Jujuy, San Luis, San Juan, Mendoza, Córdoba, Corrientes, Entre Ríos, fueron quienes de manera silenciosa 
pero constante contribuyeron a la producción doméstica que luego derivaría en algunos casos en pequeños centros productores de tejidos, fundamentalmente realizados en telar. La imagen que muchos argentinos tenemos de esta época es la que nos contaron nuestros maestros de la escuela primaria, que fuera descripta por Domingo Faustino Sarmiento en su libro Recuerdos de Provincia (1850). Su madre, Doña Paula Albarracín, aparece en la narración como un símbolo de entrega, laboriosidad y paciencia, siendo el sostén del hogar a partir de largas horas de trabajo frente al telar en el patio de su casa familiar de la ciudad de San Juan.

A poca distancia de la puerta de entrada, elevaba su copa verdinegra la patriarcal higuera que sombreaba aún en mi infancia aquel telar de mi madre, cuyos golpes y traqueteo de husos, pedales y lanzadera nos despertaba antes de salir el sol para anunciarnos que un nuevo día llegaba, y con él la necesidad de hacer por el trabajo frente a sus necesidades (Sarmiento, D. F., 1850, p. 181).

En la Patagonia o el Chaco las características de la producción de tejidos son diferentes ya que esas grandes extensiones semi desérticas fueron los últimos territorios anexados a la Nación Argentina. En el caso de la región pampeana y la Patagonia es notable la gran producción textil de grupos indígenas, fundamentalmente de origen mapuche o pampa. La denominación Pampa, que hoy está en desuso, o al menos es cuestionada por las líneas de investigación mas recientes, se utilizó para nombrar a una gran variedad de grupos étnicos que habitaban desde el Sur de la Provincia de Buenos Aires -la frontera con la civilización se situaba en el límite natural del río Salado- hasta la Patagonia norte. Pero estos grupos no eran simples parcialidades, sino complejas composiciones, producto de años de desplazamientos migratorios y procesos de aculturización, especialmente luego del fenómeno conocido como la araucanización, donde grupos procedentes del lado chileno de la cordillera de los Andes se desplazaron conquistando territorios que eran habitados por otros grupos como los tehuelches, ranqueles, puelches.

Los araucanos tenían razones políticas y económicas para esta migración transcordillerana. Los incas primero y luego los españoles realistas y los criollos republicanos ejercían presión sobre sus territorios. La búsqueda de alimentos, en un principio los animales de caza pero más adelante el ganado cimarrón (vacas u ovejas) y especialmente caballos. Comercializaban con éxito ganado en pie, cueros, plumas, sal comestible, tejidos y los intercambiaban por monedas de plata u otros insumos.

La incorporación del caballo a partir del siglo XVIII colaboró con la gran dispersión de estos grupos, sus actividades económicas y estrategias territoriales. Hacia mediados de este siglo (1735-1750) la lengua de los mapuches (llamados araucanos del otro lado de la cordillera) había reemplazado o convivía con las lenguas originales de Patagonia. Es por esos años también que su presencia física de este lado de la cordillera se hace más evidente, en coincidencia con el fin de las vaquerías (redadas de ganado libre), ya que los colonos comenzaban a asentarse en las estancias para practicar la ganadería, y a su vez la incursión de los malones de indios que las asediaban se vuelve más frecuente. Son los mapuches quienes aportan también un alto valor técnico a la tejeduría patagónica, dada la influencia de culturas andinas con las que tuvieron contacto. La producción de ponchos 
y otros textiles gana una excelente reputación en los centros urbanos como Buenos Aires, Córdoba, Mendoza y Salta, donde eran muy apreciados. El comercio de estos textiles se vio favorecido por el intercambio de mercaderías con comerciantes viajeros y sacerdotes misioneros católicos, en particular jesuitas, franciscanos y salesianos.

En cambio en el Chaco (actuales provincias de Chaco, Formosa, Noreste de Salta y Norte de Santa Fe), por sus características climáticas y geográficas, altas temperaturas, montes de difícil acceso y sin caminos, la producción textil fue mayormente dirigida por los misioneros, tanto católicos como anglicanos, para cubrir mayormente las necesidades puntuales de la población local, aunque hilados y lienzos de algodón hechos por los indígenas se intercambiaban o comercializaban en otras regiones. Los grupos étnicos chaquenses no tenían los mismos hábitos vestimentarios que los occidentales ni que las comunidades andinas. De origen amazónico, la vestimenta era más bien una ornamentación del cuerpo a partir de tejidos de red con fibras vegetales y plumas. La incorporación del ganado ovino por parte de los misioneros y el contacto con tejedores andinos llevados ex profeso dio como resultado tejidos en telar con diversas técnicas cosntructivas, que utilizan los motivos tradicionales de las bolsas y redes chaqueñas, en tipologías como ponchos y fajas. Es necesario mencionar también la influencia que tuvieron en la textilería del Noreste argentino las misiones guaraníes que la Compañía de Jesús tenía en el Paraguay (16091767). En toda la zona litoral, a lo largo del río Paraná, los ponchos de algodón y seda de origen paraguayo fueron tanto usados como imitados por los tejedores locales. Un poncho a rayas, llamado de sesenta listas, de origen jesuítico y realizado con seda y algodón, fue utilizado por Justo José de Urquiza, quien fuera gobernador de la provincia de Entre Ríos y luego Presidente argentino (1854-1860), al entrar victorioso a Buenos Aires tras la batalla de Caseros en las guerras internas de 1852, grabados de la época dan testimonio de ello. La presencia del poncho en momentos históricos, de gran importancia para la construcción de la Nación Argentina, se evidencia tanto en las crónicas históricas y literarias, como en las artes visuales y en los registros o asientos comerciales de las economías regionales desde la época colonial hasta fines del siglo XIX.

De acuerdo con las investigaciones de la historiadora Felicitas Luna, fuentes documentales aportadas por Felipe Cárdenas y Víctor Barrionuevo Iposti a la revista Todo es Historia $(s / f)$, de la que es editora, afirman que durante la guerra de la independencia, el General José de San Martín y su ejército, utilizaron ponchos en los días previos al combate de San Lorenzo, para observar al enemigo sin ser reconocidos. Al realizar el épico cruce de los Andes, en la gesta libertadora de América del Sur, San Martín sostenía que la salud de sus soldados era una de las fortalezas que los llevarían a la victoria. Conociendo las dificultades climáticas que atravesarían y con espíritu práctico recurrió a la producción artesanal del Río de la Plata para equipar a la tropa.

Sin duda, el abrigo más preciado, la indumentaria fundamental que cobijó el heroico cruce no fue la elegante capa azul que aparece con mayor frecuencia en la iconografía. La prenda que a nadie faltó durante la monumental hazaña fueron los ponchos andinos, pampeanos y arribeños provenientes de los telares indígenas y criollos. Desde el mismo General San Martín, los altos oficiales, los soldados de tropa, hasta el más humilde baqueano del Ejército de los Andes, todos ellos se cubrieron con el poncho, la prenda ancestral de los Andes que fue bandera de Libertad. 
El poncho estuvo presente en la historia de las Naciones de América del Sur, tanto desde las Misiones Jesuíticas donde se producían para comercializarse, como en tolderías y fortines, donde brindaban protección y abrigo. En las guerras de la independencia jugó un papel fundamental, convirtiéndose en un ícono. Por ejemplo, la tropa del General Güemes en la provincia de Salta estuvo conformada por gauchos, pobres y oprimidos, que con coraje decidieron defender la independencia con los recursos que tenían a mano, su caballo, sus lanzas y sus ponchos. El poncho rojo que usara Güemes, con agregados de dos listas y flecos negros en señal de luto por la muerte del general, es actualmente el símbolo de la provincia de Salta. Hoy se conservan como patrimonio histórico los ponchos que fueron usados por muchos de próceres, como San Martín, Bolívar, O’Higgins, Santa Cruz, Las Heras, etc.

\section{De sus orígenes a su expansión}

Como es sabido, el poncho es una prenda de forma rectangular que mide aproximadamente 1,80 x $140 \mathrm{~cm}$, con una abertura en el centro (llamada boca) que sirve para poderlo pasar por la cabeza. Fue usado en distintas partes del mundo: África, Oceanía, Asia y América - , con diferentes características y tamaños.

Entre nosotros, es decir en América, es de origen precolombino. Se conocen como sus antecesores tipologías similares, los unkus o camisas incas en la zona andina, así como los quillangos de cuero de los tehuelches en Patagonia. Esta prenda que combina simplicidad con refinamiento fue rápidamente adoptada por los criollos, hasta llegar a ser un símbolo de la tradición.

$\mathrm{Al}$ referirse al origen del poncho Ruth Corcuera, la principal investigadora que se dedicó su estudio nos dice:

El poncho tejido, tal como lo conocemos tradicionalmente hoy, se encuentra difundido por la mayor parte de los países de América, con más presencia sobre ambos lados del macizo andino, y conforma el patrimonio cultural de nuestros pueblos. Tiene diferentes antecedentes: ponchos trabajados con corteza de cedro entre los indios de los grandes bosques norteamericanos; ponchos de los esquimales, confeccionados con las pieles de los animales que tenían a su alcance; camisas de cuero tipo poncho, empleadas por los cazadores de búfalos de las grandes llanuras norteamericanas y realizadas con los cueros de los animales desollados. Estas últimas constituyen el estadio cultural más avanzado de esta prenda. Se las puede encontrar desde la Baja California hasta la Patagonia, y sobre todo en las proximidades de la cordillera de los Andes (Montandon, 1934, p. 340).

Respecto de la americanidad del poncho, debemos remitirnos a los trabajos de la investigadora Mary Elizabeth King (1965), quien considera que la prenda existía en la primera gran cultura andina, Paracas (700 a.C.-200 d.C.), al sur de la actual República del Perú. En estos últimos años se están revisando con nuevos criterios las grandes colecciones de 
textilería depositadas en museos de Estados Unidos, y como consecuencia han surgido otros conceptos con respecto al poncho (Corcuera, R. 2017).

De acuerdo a las crónicas de los primeros españoles que se adentraron en la región del Plata, ya en 1529 el explorador Sebastián Gaboto encuentra indígenas con ponchos al remontar el Río Paraná.

Al finalizar el siglo XVI el actual territorio argentino estaba organizado en tres distritos administrativos. Cuyo y las Gobernaciones del Tucumán y del Río de La Plata...La única fuente de riqueza que hallaron los conquistadores en ese gran espacio fue la fuerza del trabajo del indígena y su tributo, en el cual el tejido representaba uno de los elementos más importantes (Nardi, R. y Rolandi, D., 1978, p. 16).

Desde épocas virreinales los ponchos formaron parte del intercambio comercial entre regiones, más allá de los límites políticos. Fue así que en las actuales provincias del Norte argentino, eran muy comunes los llamados ponchos arribeños, realizados en los obrajes del Perú y Alto Perú (Bolivia). Muchas de estas piezas eran confeccionadas respetando la tradición jesuítica, en tiras de tejido que luego se unían para formar una prenda de anchura. Esto respondía a motivos económicos más que de diseño, ya que los misioneros habían introducido telares europeos con pedales y enjulios o plegadores en sus extremos, lo que facilitaba la realización de manera más veloz de largas piezas de tela, que luego podían cortarse y confeccionarse. Los telares utilizados antes de la llegada de los españoles -telares horizontales, verticales y de cintura- tenían algunas limitaciones respecto del tamaño del tejido, debían adaptarse según la pieza requerida. Esta manera de tejer no tenía que ver con la técnica sino más bien con una cuestión cultural, ya que según la concepción andina el tejido no debía cortarse, y es por eso que todas las tipologías prehispánicas corresponden a formas geométricas básicas, ensamblando rectángulos y cuadrados.

Esta simplicidad morfológica que caracteriza al poncho es parte del secreto de su practicidad, de allí su rápida adopción por los jinetes. Así lo consignaba Alfredo Taullard en una de las primeras publicaciones impresas sobre tejidos y ponchos indígenas de Sudamérica:

El poncho lo utilizó tanto el indio como el hombre blanco, porque sirve no sólo para protegerse de las inclemencias del tiempo, de la lluvia y del sol. Fue útil al gaucho para improvisar con él su cama al aire libre. Otras veces le servía de tapete para jugar a los naipes en sus ratos de ocio, para defender su vida en duelo criollo a cuchillo, y según un antiguo dicho campero, "hasta en los entreveros cuando se acababan las balas, a ponchazos se ganaban las posiciones" (Taullard, A., 1949, p. 95).

\section{Evolución y aceptación}

Su funcionalidad y versatilidad han hecho del poncho un elemento estratégico para el paisano, la tropa, viajeros y misioneros. No obstante, la calidad técnica y estética de su ma- 
nufactura denota un universo simbólico, que perdura hasta nuestros días, no sólo como código vestimentario sino como registro de antiguas tradiciones ágrafas, como indicador de roles y jerarquías sociales.

La prenda que hoy conocemos como poncho y que tuvo gran difusión en el continente americano, es fruto de los aportes que realizaron las distintas sociedades, culturas y tecnologías. No sólo su practicidad es la razón por la que fue adoptada por indígenas y criollos, gauchos e intelectuales, ricos y pobres, modernos y tradicionalistas.

Otro aporte lo dan la nobleza de las materias primas locales, como el pelo de la preciada vicuña (camélido silvestre que vive a más de $4000 \mathrm{msnm}$ ), la seda silvestre recolectada en algunas regiones de monte espinoso, que puede devanarse como la de morera y es de un color ocre rojizo similar a la vicuña, la lana de las ovejas criollas cruzadas con ovejas "pampas", el algodón catamarqueño (hoy desaparecido), del Chaco y del Paraguay.

Según Corcuera (1998) el poncho fue protagonista de una floreciente industria textil en la Argentina en los albores del siglo XIX. Al estudiar la producción de materias primas y manufactura de estos textiles, así como las rutas comerciales desde los centros productivos hacia las metrópolis, se comprenden aspectos sociales y económicos de tiempos que consolidaron la construcción de nuestro país, acrecentando la identidad nacional.

La presencia del poncho en momentos históricos, de gran importancia para la formación de la nación, se evidencia tanto en las crónicas históricas y literarias, como así también en las artes visuales y en los registros o asientos comerciales de las economías regionales desde la época colonial hasta fines del siglo XIX.

Nardi y Rolandi (1978) aportan datos respecto del declinamiento de estas pequeñas industrias regionales, destacando que en 1778 los reyes de la Casa de Borbón reglamentaron el comercio libre entre España y sus colonias.

Con la intención de proteger la manufactura española en creciente decadencia, permitieron la introducción de materias primas americanas, pero vendiendo gran cantidad de productos españoles y europeos que competían con la producción artesanal local. Luego de la independencia, las políticas librecambistas siguen desfavoreciendo a las manufacturas artesanales de las provincias.

A principios del siglo XIX, y producto de la revolución industrial que venía desarrollándose desde mediados del siglo XVIII, el mercado local se vió inundado de ponchos industriales de origen inglés, confeccionados con lana merino llevada de la Patagonia argentina y de las colonias inglesas como Australia y Nueva Zelanda. Es frecuente encontrar en fotografías de la época gauchos en sus quehaceres cotidianos, usando ponchos ingleses. Su diseño es notablemente diferente en cuanto a los patrones y colores utilizados a los ponchos tejidos a mano, además de ser evidentemente más económicos. Las familias y pequeños talleres continuaron tejiendo sus ponchos, con mayor calidad, diseños tradicionales y materias primas locales, los que convivían en los boliches o almacenes de campo junto a estos nuevos productos importados. No obstante, siempre se mantuvo un comercio interprovinciano de tejidos, con productos característicos de cada región.

Figuras de la política y de la cultura argentina lucieron ponchos en numerosas ocasiones. Las agrupaciones tradicionalistas ${ }^{1}$ desfilaron en sus galas los atesorados ponchos de sus antepasados y siguen haciéndolo con orgullo en la actualidad, desde el pueblo mas humilde hasta la Sociedad Rural de Palermo. 
En 1935 muere en Medellín, Colombia Carlos Gardel, después de un largo viaje hacia Buenos Aires, el artista icónico del tango llevaba sobre su féretro el poncho que usara en sus viajes y que lucía su nombre bordado en uno de sus ángulos. El poncho caló tan hondo en las costumbres y el sentir del pueblo que también se cristalizó en metáfora. Gardel fue autor junto a Andrés Cepeda del Tango del olvido cuyos versos -entre otros- dicen:

\author{
Aunque el poncho del olvido \\ sobre mi lomo has echado \\ los recuerdos del pasado \\ deben haberte seguido... \\ Nada tiene duración \\ en este mundo mezquino \\ en desparejo camino \\ cualquiera da un tropezón \\ vos me distes una lección \\ que la supe aprovechar \\ me enseñastes a olvidar, \\ y como lo he aprendido \\ con el poncho del olvido \\ también te quiero tapar. \\ (Cepeda, A. 1912).
}

Los ponchos pueden dar testimonio, como síntesis del pensamiento y de la cultura popular, así como de los acontecimientos históricos de relevancia en la formación nuestra Nación.

\title{
Integración y perspectivas
}

La idea de Nación implica una historia común, así como una identidad política imaginada, no sólo por la dominación territorial, sino por la suma de voluntades de pertenencia a un ideal colectivo, donde la noción de comunidad supone solidaridad y fraternidad. El deseo de constituirse en unidad y autonomía trae finalmente en 1853 la sanción de la Constitución Nacional de la República Argentina, que en su artículo 25 decía:

El Gobierno Federal fomentará la inmigración europea; y no podrá restringir, limitar ni gravar con impuesto alguno la entrada en el territorio argentino de los extranjeros que traigan por objeto labrar la tierra, mejorar las industrias e introducir y enseñar las ciencias y las artes

Como resultado de estos procesos que conforman una nueva sociedad, más diversa y en apariencia disímil y atomizada, se pone en marcha un cambio económico y social. Los primeros ensayos de colonización en el país comienzan bajo el gobierno de Urquiza. La primera colonia se establece en Santa Fe, en 1865 con el nombre de Colonia Esperanza, donde la mayoría de los colonos eran de origen suizo, alemán y francés. 
Las colonias de galeses se instalaron en la Patagonia, llegando a Puerto Madryn, en 1865. En 1878 se fundaron colonias en Resistencia (provincia del Chaco).

Hacia 1880 el aluvión migratorio se acentúa, como producto del contexto mundial y de las políticas de la llamada generación del 80 (los presidentes Mitre, Sarmiento, Avellaneda) con sus teorías acerca de la importancia del poblamiento del país. Entre 1886 y 1870 el país recibió 160.000 inmigrantes mientras que entre 1881 y 1890 la cantidad de inmigrantes fue de 841.000, estos últimos de origen español e italiano mayoritariamente, pero también ingleses, polacos, rusos, sirios, libaneses y armenios.

Las magníficas posibilidades de la República Argentina, las guerras y dificultades europeas atrajeron una fuerte corriente inmigratoria. Este poblamiento no fue seguido de una asimilación inmediata.

La Argentina necesitaba mano de obra, como consecuencia del proyecto de expansión del sector agropecuario; y Europa liberaba mano de obra, como consecuencia de la tecnificación del agro y la Segunda Revolución Industrial.

La construcción del ferrocarril creó una importante fuente de trabajo para los inmigrantes y desencadenó un cambio radical en la economía del país.

No obstante, los inmigrantes necesitaban trabajar e integrarse a la sociedad. Si bien al comienzo no fueron aceptados socialmente en los círculos criollos, su gran capacidad de emprender y fuerza de trabajo, fueron herramientas para conseguir una esforzada prosperidad, y ganar prestigio social en la próximas generaciones, que tuvieron acceso a una mayor educación. La cultura de los inmigrantes hizo también sus aportes, no solo al lenguaje y las costumbres, sino también a las técnicas y estilos en las artes y el diseño. Con reciprocidad, la cultura nativa se fusionó con estos nuevos elementos, generando un nuevo estilo mestizo o criollo. Los ejemplos mas notables se observan en la platería y la textilería.

\section{Ponchos en la exposición del Bicentenario}

En 2017 se cumplieron 200 años del Cruce de los Andes realizado por José de San Martín y el Museo de Arte Popular José Hernández de la ciudad de Buenos Aires, decidió festejar este acontecimiento histórico con la exposición Ponchos en el Bicentenario.

En el salón principal y con una nueva puesta museográfica se exhiben más de 20 ponchos del patrimonio de esa institución, a los que se suman piezas pertenecientes al acervo del Museo Histórico Nacional y, de coleccionistas particulares.

La gran mayoría de estos ponchos fueron adquiridos a fines del siglo XIX y principios del XX por Carlos Guillermo Daws (1870-1947), un coleccionista apasionado por lo criollo y el mundo del campo. Descendiente de irlandeses y empleado del ferrocarril, Daws seleccionó con buen ojo y criterio, ponchos, platería, trabajos en cuero, asta, aperos y cientos de mates. Al morir -y no dejar descendencia-, su colección fue comprada en la década del 50 por la municipalidad para dar prestigio al recién creado Museo de Motivos Argentinos. Convocada por la directora Felicitas Luna, para hacer la curaduría y selección de los ponchos para esta exposición, abordé una tarea compleja, dada la gran calidad y cantidad de los mismos; Me propuse encararla con una mirada crítica y didáctica pensando en el visitante y en sus diferentes edades y maneras de relacionarse con el tema. 
La investigación, -al igual que las tareas de conservación-, comenzaron en el 2015. Se relevaron, estabilizaron y pusieron en valor todas las piezas textiles. Se contó con especialistas en conservación ${ }^{2}$ restauración y consolidación de los ponchos ${ }^{3}$. También se encaró un plan de conservación textil, algo que, hasta entonces nunca se había realizado profesionalmente. Se reubicaron las piezas, limpiaron, clasificaron, fotografiaron, protegieron y guardaron con material de conservación.

Durante la investigación y producción de la muestra tuvimos el acompañamiento entusiasta de Ruth Corcuera, con su manantial de conocimientos y generosidad intelectual, que nos aportó valiosa información y comentarios.

En paralelo, trabajé en los criterios museográficos y el guión curatorial.

En él no debía perder de vista la importancia de llegar a nuevos públicos, con un mensaje renovado que incluyera la presencia del poncho en la moda actual, tanto en los usos de la juventud argentina como en las principales pasarelas del mundo.

El concepto de la exhibición era celebrar el Bicentenario de la Independencia en 1816 y del Cruce de los Andes 1817, gestas que marcaron el destino de la Argentina como república. En el salón central del museo, pintado el de color lacre y gris, e, iluminando el acceso, se lee un cartel introductorio con el texto curatorial que reproduzco parcialmente:

Este símbolo de nuestra identidad que es el Poncho, narra la historia de caciques y paisanos, de próceres y gauchos, de jesuitas y de arrieros, de tejedores e hilanderas, ...es decir, también de todo lo que hay detrás del poncho, tanto de los personajes como de los hacedores, del paisaje natural e indómito donde nace y de los motivos que acreditan su vigencia (González Eliçabe, X., 2017).

Los núcleos temáticos de esta exposición los agrupé en función de distintas vertientes históricas, técnicas y productivas, con sus diversos aportes culturales, que se difunden con el poncho. Su uso asociado a lo indígena y a lo criollo revela una sociedad mestiza, enriquecida por lenguajes provenientes de distintas cosmovisiones, por los materiales nobles de la tierra, por la abundancia de formas y diseños.

En esta muestra se observan ponchos del Sur, tejidos en telar vertical con técnicas de laboreo, ikat o lista atada; ponchos de tradición jesuítica de origen peruano, tejidos en franjas en telar de cintura y otros en telar horizontal. Incluso uno de 60 listas, de seda y algodón proveniente de Paraguay, colección del museo. También los hay de vicuña y seda, de chinchilla y alpaca del siglo XVIII, ponchos ingleses tejidos a máquina y estampados. Si bien la mayoría se realizaron entre el siglo XIX y principios del XX, se exponen ponchos actuales, como el blanco (crudo) que proviene de la remota localidad puneña de Laguna Blanca, de Catamarca, íntegramente hilado y tejido en panza de vicuña, que empleó la mano de obra de varias personas y 4 años para su elaboración, dada la escasez de esta preciada fibra. Durante la inauguración, el Correo Argentino presentó una serie filatélica de sellos postales de colección con ponchos del museo. Posteriormente se organizaron visitas guiadas para niños y adultos, performance con diseñadores emergentes que incluyen ponchos en sus colecciones, fotografías contemporáneas y de moda ${ }^{4}$ fueron algunas de las actividades que se hicieron paralelamente a esta exhibición.

A través de esta muestra, podemos acceder a un patrimonio valioso, pocas veces reunido con anterioridad, hacer una lectura de material, forma y color, adentrarse en su simbolis- 
mo, apreciar la exquisitez de sus técnicas. Hoy el poncho está de moda y su valoración nos lleva a pensar la importancia de nuestro pasado y a resignificarlo para el futuro.

\section{Conclusión}

En estos tiempos fluctuantes, hay elementos, producto de la cultura, que resultan eficientes para lograr la integración social, mirarse en el espejo del otro, reconociéndose como un grupo de pertenencia a ciertos valores, maneras de ser y de elegir. El poncho ha sido y es uno de ellos; no sólo resistió airoso el paso del tiempo, adaptándose a la dinámica de las épocas políticas y económicas por las que atravesó, soportando los embates en su atávica forma de producción, sino que se enriqueció con aportes de diferentes vertientes culturales. Se fortaleció y logró la permanencia en el cambio, reinventándose continuamente. Protector y compañero, arquetipo de la contradicción entre lo salvaje y el refinamiento, el poncho es bandera, símbolo de unión y libertad.

\section{Notas}

1. La investigadora Cecilia Pissarello define al Tradicionalismo o "Movimiento Social Gaucho", como también es llamado por sus propios actores, como un fenómeno que representa la voluntad de transmitir la tradición nacional, en manifestaciones culturales referidas a la cultura ecuestre y expresiones de la música folklórica, las danzas nativas y la artesanía criolla. Sus agrupaciones organizan ceremonias en conmemoración de las fechas patrias y de quienes conforman el panteón de héroes, reivindicando la lucha por la independencia y la construcción de la nación.

2. Equipo liderado por María José Cabal.

3. La restauración estuvo a cargo de Nolia Ganame.

4. El fotógrafo Gustavo Dimario expuso en la muestra fotografías de moda y documentales del uso del poncho en la actualidad.

\section{Bibliografía}

Anderson, B. (1991). Imagined communities: Reflections on the origins and spread of nationalism". 2da Ed. Londres: Verso.

Corcuera, R. (2017). Ponchos de América. Buenos Aires: Fundación CEPPA.

“Culturas indígenas de la Patagonia”. Catálogo de la exposición homónima, Museo Etnológico de Barcelona enero 1984, Museo Arqueológico de Madrid, marzo 1984, Museo Arqueológico de Sevilla, mayo 1984. Ciclo "Las culturas de América en la época del descubrimiento". Comisión Nacional del V Centenario del Descubrimiento de América.

Nardi, R. L. J. y Rolandi, D. (1978). 100 años de tejido en la Argentina. Ministerio de Cultura y Educación de la Nación: Buenos Aires.

Sarmiento, D. F. (1937). Recuerdos de provincia. Buenos Aires: Talleres gráficos argentinos L. J. Rosso. 
Taullard, A. (1949). Tejidos y ponchos indígenas de Sudamérica. Buenos Aires: Editorial Guillermo Kraft Ltda. www.argentinaxplora.com

\begin{abstract}
The poncho has been a present element since ancient times, an essential object in the daily life of the American man. Over the centuries and with different cultural contributions, it has become a symbol of our identity. The poncho participated in the history of the Nations of South America, both from the Jesuit Missions where they were produced to be marketed, and in tolderias and pillboxes, where they provided protection and shelter. The poncho was the protagonist of a flourishing textile industry in Argentina at the beginning of the 19th century. When studying the production of raw materials and manufacturing of these textiles, as well as the commercial routes from the productive centers to the metropolis, we can understand social and economic aspects of the times that consolidated the construction of the Republic and enhanced the national identity. It currently appears in the most important international catwalks and street fashion also testifies to its acceptance as a trend. Young Argentine designers are projected in the world of global design, proud of their identity, incorporating ponchos in their collections, with raw materials and novel fabrics, searching for new possible uses that does not recognize categories or protocols.
\end{abstract}

Keywords: Culture - identity - history - Republic - economics - social policy - evolution - trends - design.

Resumo: O poncho tem sido um elemento presente, um objeto desde os tempos antigos essencial na vida cotidiana do homem americano. Através dos séculos e com diferentes contribuições culturais tornaram-se um símbolo da nossa identidade. Ele participou da história das Nações da América do Sul, tanto das missões jesuítas onde foram produzidos para serem comercializados, como em tolderias e pillboxes, onde les deram proteção e abrigo. O poncho foi o protagonista de uma florescente indústria têxtil na Argentina no início do século XIX. Ao estudar a produção de matérias-primas e fabricar essas têxteis assim como as rotas comerciais dos centros produtivos para as metrópoles, compreender os aspectos sociais e econômicos dos tempos que consolidaram a construção da República, aumentando a identidade nacional. Atualmente aparece nas mais importantes passarelas e moda internacionais do país e também atesta sua aceitação como uma tendência. Jovens designers argentinos somos projetados para o mundo do design global, orgulhosos de sua identidade, incorporando ponchos em suas coleções, com matérias-primas e tecidos novos, procurando novos possíveis usos para esta tipologia que não reconhece itens ou protocolos.

Palavras chave: Cultura - identidade - história - república - economia - política social evolução - tendências - design.

[Las traducciones de los abstracts fueron supervisadas por el autor de cada artículo] 
Fecha de recepción: abril 2019 Fecha de aceptación: octubre 2019 Versión final: marzo 2020

\section{Diseño de indumentaria: Nuevas estrategias de enseñanza y modelos de innovación en el marco del consumo de moda}

Verónica Fiorini *

\begin{abstract}
Resumen: Este artículo se propone abordar ciertos cambios en los modelos metodológicos que se desarrollan en el campo de la enseñanza del proyecto en indumentaria. El impacto de las transformaciones socioculturales en los modelos de consumo, la emergencia de otras lógicas de producción de los mensajes y discursos comunicacionales en el campo de la moda son aspectos que obligan a revisar las concepciones disciplinares en la educación en diseño y en el campo profesional. Hay dos aspectos claves que se analizarán en este trabajo: los modos de pensar y enseñar el diseño y sus objetos resultantes en su relación con las experiencias de consumo que proponen en tanto valor-signo (Baudrillard). El contexto contemporáneo, incierto y fluctuante también traza un panorama de alta complejidad. La emergencia de las identidades locales, en un mundo altamente globalizado, merece ser revisado, en tanto redefine la lógica del campo disciplinar (Bourdieu) y los discursos que son legitimados en el mismo (Verón).
\end{abstract}

Palabras clave: metodologías - proyecto - diseño de indumentaria - modelos y experiencias de consumo - educación - comunicación - signo - discursividad - interdiscursividad.

[Resúmenes en inglés y portugués en la página 60]

${ }^{(*)}$ Magister en Diseño Comunicacional (DICOM) de la FADU UBA. Diseñadora de Indumentaria (UBA). Especialista en Gestión Estratégica de Diseño - Gerenciamiento de Proyecto y de Diseño Comunicacional. Magister en curso de la maestría DICOM (UBA). Profesora de la Universidad de Palermo en el Área de Moda y Tendencia en la Facultad de Diseño y Comunicación. Actualmente trabaja como diseñadora en su propia marca. Tiene varias publicaciones: "Del diseño al producto", capítulo del libro Desing de Moda, diversos olhares; "Diseño de indumentaria, aspectos conceptuales y metodológicos. Armado de colección" en Cuadernos de Cátedra FADU-UBA 2009; "Acerca del Método" en Revista Contextos de la UBA; entre otros.

Ver desfiles de la Cátedra de Verónica Fiorini en Moda en Palermo.

Pertenece a la Facultad de Diseño y Comunicación desde el año 2011. 


\section{Introducción}

Este trabajo tiene como objetivo abordar ciertos cambios en los modelos metodológicos del diseño de indumentaria en relación a las transformaciones socioculturales de consumo. También se revisarán algunas nociones ligadas a la emergencia de otras lógicas de producción y distribución de los significados de los objetos de diseño en el campo de la moda. Estos lineamientos suponen una revisión obligada de ciertas concepciones disciplinares que podemos resumir en dos grandes ejes:

1. Ciertos modos de pensar el diseño de indumentaria en sus visiones metodológicas y con respecto a la innovación.

2. Sus implicancias discursivas en relación a las experiencias de consumo que proponen dichos objetos de diseño: interdiscursividad en el diseño de indumentaria.

\section{Revisiones metodológicas en el campo del diseño de indumentaria}

Podemos afirmar que el contexto cultural y social contemporáneo, asume algunos rasgos globales y locales de cambios profundos, signados por una fuerte incertidumbre, grandes fluctuaciones y una tensión permanente entre las tradiciones disciplinares, los discursos legitimados por las mismas, y sus potenciales rupturas.

El diseño definitivamente ya no está únicamente ligado a la producción de objetos, tampoco de búsquedas puramente formales, sino a un estadío en donde lo que importa es principalmente el proceso de construcción del discurso del diseño y los significados que evocan estos objetos vestimentarios.

En este sentido, retomamos la concepción planteada por E. Verón (2004): "La noción de discurso designa, no únicamente la materia lingüística, sino todo conjunto significante considerado como tal (es decir como lugar investido de sentido)" (2004, p. 48). En este marco teórico, hay que subrayar la importancia que le otorga a las redes interdiscursivas que permiten reconocer las condiciones de producción y reconocimiento de los discursos. Es decir: "Todo discurso constituye un fenómeno de reconocimiento de los discursos que forman parte de sus condiciones de producción" (2004, p. 54).

Esta teoría retoma aspectos desarrollados por Peirce, para quien la semiosis es ternaria, social, infinita e histórica (2004, p. 56). Esta definición de discurso de Verón nos permite situar a la disciplina del diseño de indumentaria como un campo (Bourdieu) generador de discursos.

Para L. Arfuch (1997) se presenta el diseño como "trama cultural", es decir excede la actividad proyectual individual y se impone como hecho significativo (1997, p. 224). La autora señala que el diseño aparece allí donde todo está dicho, en un espesor hecho de historia, tradiciones, usos culturales, huellas, palabras de otros.

En este sentido, la metodología clásica proyectual, presenta aspectos que merecen ser discutidos y revisados a la luz de nuevas teorías, o al menos de aquellas aproximaciones que se presentan como nuevos discursos sobre como diseñar. 
En los procesos metodológicos tradicionales, herederos del discurso del diseño moderno, las fases clásicas se dividían, a grandes rasgos, en tres etapas diferenciadas:

- Fase investigativa y de detección de problemas de diseño

- Fase inventiva o creativa

- Fase ejecutiva y de concreción/verificación

Autores de distinta procedencia rescatan aspectos centrales de estos métodos proyectuales herederos del pensar de la modernidad a los largo de varias décadas del siglo XX: Maldonado, Bonsiepe, Munari, Bürdek y otros defensores de esos discursos. Incluso autores como Koberg que trabajan las nociones de circularidad y retroacción en los procesos de diseño no dejan de plantear la existencia de estas fases, aunque subviertan la lógica lineal y adviertan su complejidad creciente.

En todos estos esquemas que derivan de la concepción moderna, se advierte como fuerte influencia de la gramática de producción, el discurso funcionalista. El objeto funcional cobra valor como objeto signo, tal como lo advierte Baudrillard (1974) plantea una suerte de fachada, que vuelve opacas, al naturalizarlas, las ideas centrales del funcionalismo moderno.

En el contexto contemporáneo posmoderno, los discursos sobre las metodologías se subvierten. Lo que Baudrillard (1974) menciona como objeto valor-signo se vuelve primordial. La significación del objeto pasa a primer plano en los modelos de consumo vigentes. Ante tanta profusión de objetos y aceleración del consumo a nivel global, se advierten de este modo una serie de interrogantes:

¿De qué modo se plantean los discursos de diseño de indumentaria dentro de este modelo de obsolescencia programada acelerada que nos propone el sistema de la moda?

¿Cómo se implementan los modelos actuales de innovación en relación al pensamiento de diseño y en relación a los objetos y su producción?

¿Qué experiencias y otros discursos evocan, como se relacionan interdicursivamente con otras áreas del conocimiento y la cultura?

$\mathrm{Al}$ ahondar en los factores de innovación, autores como R. Leiro (2006), subrayan la importancia de no diseñar sobre lo ya diseñado, de proponer una ruptura innovadora a partir de la re conceptualización radical del objeto de diseño.

Este autor destaca tres fases remarcables:

1. Adaptación del diseño a los modelos culturales vigentes

2. Cambio sustancial de los significados

3. Creación de nuevos significados

Es decir, que la innovación puede presentar diferentes niveles de intensidad respecto al plano simbólico en relación al contexto sociocultural en el que está inserto.

Para Jaakko Tammela (2016), estamos en un momento de grandes transformaciones desde una perspectiva proyectual. Su planteo teórico hace hincapié en el gran cambio que significa para el diseño, tradicionalmente ligado a la lógica industrial (cuyo inicio sitúa en la Revolución Industrial). En ese contexto "la sustitución del trabajo artesanal autónomo 
por el trabajo asalariado y el uso de máquinas para la producción, aumentó drásticamente la capacidad humana" (más rápida y más fuerte como civilización). Ante la propuesta de un nuevo diseño industrial, remarca la pregunta: ¿"Estoy diseñando un nuevo vaso de agua o una manera de matar la sed?" (2016). Pensando un correlato en indumentaria uno podría preguntarse ¿Estoy diseñando un nuevo atuendo o una nueva concepción del vestir? Esta doble pregunta nos marca de manera ejemplar que la identificación del problema es siempre el pilar de la innovación proyectual. A este planteo podríamos agregar una nueva pregunta ¿Cuáles son los discursos emergentes sobre ese objeto en el plano de la experiencia y de la significación que pueden enriquecer la idea de diseño?

Para este autor diseñar es una profesión imaginativa y productiva $(2016$, p. 31) en tanto trabaja entre el mundo de las ideas y la producción de algo concreto. En la era del pensamiento digital, señala que los modelos de pensamiento se tornan inciertos, flexibles y conectados. Para Tammela es "crear lo no imaginado" pero la pregunta es ¿Cómo imaginar aquello que no fue creado hasta entonces? De qué manera los estudiantes y diseñadores pueden imaginar la innovación (2016, p. 32).

En este sentido podemos tomar la diferenciación planteada por el Profesor T. Buganza (2003) rescatada por R. Leiro (2006) quién distingue en el mundo del diseño aquellos objetos que proponen una mejora incremental y aquellos que se constituyen como innovaciones radicales. Esta definición es retomada por R. Leiro (2006, p. 207) a propósito de la marca de accesorios Swatch, quién redefine la categoría reloj como objeto de moda, principalmente.

\section{Innovación y nuevas tecnologías: interdiscursividad y diseño de indumentaria}

Las transformaciones tecnológicas alteran nuestros modos de entender el mundo, de visualizarlo y experimentarlo. El diseñador de indumentaria tiene entonces la oportunidad de repensar nuevas soluciones para nuevos problemas de diseño, y en este sentido construir nuevos discursos sobre lo que es un diseño tecnológico y también dialogar con aquellos discursos que se constituyen como "tendencias socioculturales de consumo"1. Las relaciones entre diseño y cultura son cruciales para entender cómo se producen los objetos vestimentarios y las ideas o conceptos que éstos proponen en el campo de la significación. Un buen ejemplo es la serie audiovisual Black Mirror ${ }^{2}$, en la cual se plantean distintos dilemas en una sociedad cambiante y determinada por las tecnologías en un sentido crítico. En uno de sus capítulos, las relaciones humanas hombre-mujer tienen una fecha de caducidad a partir de un dispositivo tecnológico, es decir suponen una fecha de vencimiento. En otro capítulo de la serie, una madre se obsesiona por controlar a su hija mediante un dispositivo técnico hasta anular de manera total su privacidad y su encuentro con situaciones conflictivas.

Estos discursos que parecen transitar lo ficticio y los lenguajes de la ciencia ficción son esbozados desde el campo de la indumentaria. Desarrollos de prendas que posibilitan la visión 360 grados y ejercer cierto grado de control ya constituyen espacios de exploración en el diseño de indumentaria. La inclusión de dispositivos tecnológicos en las prendas, 
que mantienen al tanto al usuario de situaciones que ocurren en sus comunicaciones ya son parte del presente. La empresa Levis (2018) ha desarrollado con éxito y con última tecnología la concreción de esta cruza interdisciplinaria.

La denominada chaqueta inteligente de Levis, posee sensores y botones que controlan el móvil (denominado Project Jacquard, con Levis commuter Trucker Jacket). El ingeniero del proyecto Iván Poupyrev plantea que dicho producto ha sido desarrollado para "ayudarte a controlar tu vida digital mientras estás en el mundo real” (Bohn, 2017). Dentro del mundo de los wearables, dicho producto, se puede lavar fácilmente. Con solo determinados gestos o hacer toques en la ropa puede suspenderse la música o recibir indicaciones de google maps, o escuchar mensajes leídos por un asistente virtual.

En Argentina, también se ha desarrollado un dispositivo en la indumentaria que permite detectar caídas en personas mayores a larga distancia, implemento que busca ayudar tecnológicamente en términos de cuidado de la salud corporal.

De este modo, el cuerpo se vuelve no solo soporte de la vestimenta, sino de los dispositivos móviles de una manera más mimética. También es posible afirmar que este tipo de prendas anticipan un cambio en la gestualidad del usuario, una innovación en los movimientos del mismo y por ende en la comunicación no verbal. Del mismo modo podemos afirmar que varias películas o series de ciencia ficción como Black Mirror forman parte de la gramática de producción de estos discursos del diseño. De eso se trata la inter-discursividad en el campo cultural.

En otro caso emblemático, las zapatillas Nike que se ajustan solas sin intervención del usuario (fantasía desplegada en la legendaria película de los años ochenta Volver al futuro) ya fueron presentadas durante 2017 por la marca. Es decir, la búsqueda de objetos que actúan sin el usuario, actúan por su cuenta, de modo independiente. Este concepto es una idea de profundo impacto que nos demuestra el lazo indisoluble entre los discursos del diseño y la cultura. Los modos en que se esbozan los imaginarios de futuro están en diálogo permanente con las imágenes que construyen los discursos actuales del diseño, demostrando plenamente la inter-discursividad en los objetos vestimentarios.

Con respecto a la innovación, en diseño de indumentaria, también son dignos de remarcar los casos en donde se presentan rupturas con los discursos imperantes del campo. En este sentido, en los procesos de diseño y de enseñanza del diseño, son muy importantes los cambios discursivos para producir un nuevo producto, un nuevo desarrollo proyectual. En el caso de las camperas de la marca Uniqlo ${ }^{3}$ se evidencia claramente como un cambio discursivo genera un cambio material y formal en las prendas.

En vez de presentar la idea de un abrigo, desde mi punto de vista, presentan la idea de la desmaterialización, es decir, "un objeto de abrigo como una vestimenta que casi no existe por ser tan liviana”. La liviandad y la compresión son la antítesis del abrigo. Por eso la resultante fue un producto con alta tasa de innovación, muy imitado por otras marcas a nivel global. Que luego fue imitado en la industria de manera exponencial.

En el caso del diseño de accesorios, el desarrollo de otro tipo de zapatillas Nike que pueden ayudar a contabilizar los pasos, a seguir el ritmo cardíaco, etc. no solo promueven un cambio tecnológico, sino que proponen un discurso de control sobre el propio cuerpo. Es decir, la indumentaria controla a su usuario y no al revés. Lo informa y pasa de ser un objeto inanimado a tener "vida propia". 
La detección y búsqueda de estas performances de estos productos están asociadas a una profunda observación de los usuarios, sus inquietudes, sus preferencias, gustos e inclinaciones. En este sentido resulta relevante el abordaje metodológico que proponen algunos autores vinculados al design thinking como E. Lupton (2011).

En algunos de los planteos esbozados por el denominado design thinking, planteados en su obra, se reflejan, de modo un tanto esquemático, aquello que el campo proyectual ya ponía en práctica: conceptualización, jerarquización, resignificación, deconstrucción de los problemas, innovación radical e incremental. Nuevas herramientas como mapas conceptuales, volcado visual de datos pero una estructura similar en términos de pensamiento proyectual. Para el Innovation Factory Institute de Barcelona, (2013), el design thinking se presenta como una aproximación metodológica para los procesos de innovación en diseño. Se centra en el proceso más que en el producto final y apunta a enfocar a las personas como eje clave de observación por parte del diseñador. La comprensión del usuario y su interacción con el producto son el punto de partida para la innovación proyectual. Pero a pesar de centrarse más en el proceso, no se aleja drásticamente de los procesos proyectuales clásicos, sino que los complejiza, los vuelve más permeables a los fenómenos sociales y culturales y menos lineales.

Si en los métodos tradicionales de diseño las etapas centrales giraban en torno al estudio de problemas de diseño y sus condicionantes, creación y resolución técnica-verificación, podemos afirmar que en los modos de diseño actual existen instancias más profundas de la relación diseño-usuario-experiencia-discurso. Por otra parte, en estos abordajes se vuelven claves los términos y las palabras identificadas y utilizadas. El trabajo sobre mapas conceptuales que orientan, a modo de guía, a través del lenguaje, una búsqueda más certera, con un fuerte lazo con las personas que utilizarán esas prendas de vestir o esos accesorios de diseño.

Para la diseñadora italiana Nanni Strada (2009) la relación diseño y lenguaje es estrecha y determinante. En sus desarrollos pedagógicos respecto al proyecto sitúa la concepción del lenguaje como un aspecto central en la creación de indumentaria con alto valor desde el punto de vista del sentido.

En este sentido, podemos avanzar pensando que discursos sociales y culturales posibilitan la lectura de que ese objeto es posible y deseable en términos conceptuales? ¿Qué experiencias evocan y cuales proponen de manera concreta? ¿Quiénes pueden estar interesados en esa gama de experiencias y como se enraizan en otras creencias, valores e ideas?

Una marca como Melissa plantea una serie de experiencias ligadas a un consumo lúdico donde el calzado es casi un juguete, un objeto artificioso, alegre, con reminiscencias infantiles.

Dentro del campo de diseño de autor ocurre algo similar. Los discursos se construyen sobre la base de deconstruir aspectos del rubro, de esa categoría de objetos. El planteo posmoderno en el diseño nacional argentino, encuentra un exponente interesante en el diseñador Marcelo Giacobbe. El concepto de un nuevo lujo artesanal, democratizado, no ostentoso y con un fino y delicado rasgo glamoroso se puede enlazar discursivamente con la idea innovadora de deconstruir la concepción tradicional de la ropa de noche, de la alta costura. Es decir, sigue siendo indumentaria a medida, con apliques, bordados, pero con una nueva aproximación discursiva. 
Para D. Norman (2005) los principales componentes del diseño de producto son: la usabilidad (o su ausencia), la estética y la utilidad práctica. "Pero lo que muchos diseñadores no perciben es que existe un fuerte componente emocional en el modo en que los productos son diseñados y utilizados". La teoría de Norman es que este factor emocional puede ser mucho más decisivo que el aspecto práctico de los objetos de diseño a la hora de elegirlos. Además de visualizar la interdiscursividad en relación a las nuevas tecnologías, también es pertinente recalcar casos de interdiscursividad en el diseño asociado a las problemáticas políticas, sociales y ambientales. Son aquellas propuestas, cuyo fin decisivo es la denuncia, la acción y también en ciertos casos la colaboración directa en problemáticas de índole social. En el campo pedagógico en Argentina, podemos citar el ejemplo de varias alumnas de la Universidad de Palermo (Diseño VI, 2017) que desarrollaron, bajo la supervisión de Fábrica (organismo dependiente de área gubernamental) y de la materia diseño VI, prendas de lluvia para personas de bajos recursos de las zonas inundables del litoral argentino. En este caso, la problemática central era relacionar una producción de una marca propia que incluyera una línea de fuerte impacto social. En términos sustentables, podemos remarcar que el diseñador-estudiante articula su producción con las necesidades de su región, de su cultura. El material de base eran banners de vinilo reciclados, y esa materia prima era procesada y repensada en clave funcional. La posibilidad de compactar el producto, que sea de fácil traslado y que pueda articularse con objetos escolares para que los estudiantes guarden, fueron algunos de los desafíos que asumieron desde el punto de vista metodológico. En términos discursivos, se buscó aunar la conciencia ambiental y social con la producción de una marca dentro del sistema de la moda. Es decir, que metodológicamente se vinculan problemas de diseño, necesidades locales sociales y ambientales.

De ese modo, se establece una formación consciente de los cambios contextuales.

En Latinoamérica, la mirada política de la moda contemporánea se presenta de un modo innegable en las colecciones de Ronaldo Fraga. Cuando muestra su colección (2016) inspirada en los discursos del amor, que el mayor acto de rebeldía en el contexto contemporáneo es justamente hablar del amor, marca un discurso potente y provocador en el campo de la moda. En términos interdiscursivos, sus anteriores colecciones tocan temas urticantes, desde el mundial de fútbol, las favelas, y problemáticas sociales y políticas.

También podemos afirmar que existe otra aproximación digna de remarcar, en cuanto a un posicionamiento que cuestiona las mismas bases del campo, es decir la obsolescencia programada de los productos vestimentarios. Este posicionamiento va en un sentido discursivo, en contra de las reglas básicas del sistema, pero tal como señala F Davis, se constituye como una "falsa" negación del consumo de moda (1992). Para ejemplificar esta postura, señala la austeridad y el minimalismo como modo de freno ante el sistema de la moda. Desde el modelo impuesto por Calvin Klein en los años 90, las propuestas de la primera etapa del diseñador Alexander Wang, o marcas argentinas como Kostume o Dubié, varias marcas desafían desde una visión estética, de economía de recursos materiales y formales, la noción tradicional de la indumentaria de moda.

$\mathrm{Al}$ respecto, resulta necesario subrayar el lazo conceptual entre el minimalismo y el funcionalismo moderno. En ambos se repite la abolición del ornamento, el énfasis en la estructura, aunque a veces se presente deconstruída y en las formas limpias. La experiencia pro- 
puesta desde este tipo de diseño es consumir menos cantidad de prendas, más duraderas, de mejor calidad y que comunicacionalmente emanen una idea de pureza y simplicidad. Desde otra óptica, en las antípodas del neo minimalismo, también se sitúa la exaltación del denominado mal gusto que juega con cierta rebeldía respecto al campo de la moda, pero dentro de su lógica. Marcas y diseñadores posmodernos se rebelan contra el gusto imperante y bucean en categorías relacionadas con el neo kitsch o el denominado gusto "vulgar", a nivel global y local. En dichas marcas abunda la cita histórica, la exageración del ornamento, y la valoración de lo artesanal en un sentido glamoroso. Marcas como Prada, Versace, $D y G$, y en una escala más masiva en Latinoamérica, la marca argentina Jazmín Chebar intentan abordar este tipo de discursos que desafían las categorías impuestas por la moda como campo.

\section{A modo de recapitulación}

Lejos de cerrar el debate, estas líneas solo se proponen subrayar algunas problemáticas desplegadas a lo largo de este texto, que constituyen un punto de partida para futuros trabajos teóricos dentro del campo.

A lo largo de este desarrollo teórico se buscó puntualizar algunos cambios en los modos de pensar el diseño de indumentaria desde una óptica metodológica, focalizando en algunas transformaciones respecto al modelo de proyecto moderno y ahondando en las experiencias actuales en el campo del diseño contemporáneo a nivel local y global. A través del estudio de casos de ambos contextos, se ha vislumbrado la creciente complejidad discursiva en el campo de la moda.

Con ese objetivo se relevaron algunos aspectos relacionados al diseño de experiencias, diseño emocional y design thinking, como algunos modelos de pensamiento que permiten vislumbrar otras aristas metodológicas dentro del área disciplinar.

Por otra parte, se intentaron dilucidar distintos enfoques sobre los modelos de innovación en el campo de la moda, abarcando cuestiones relativas a la relación diseño, discurso y lenguaje, y haciendo hincapié en la noción de interdiscursividad presente en la disciplina del diseño y en el campo de la moda. Algunos de estos diálogos interdiscursivos abarcaron relaciones entre diseño y tecnologías, así como diseño, política y sustentabilidad asociada a la identidad.

La complejidad comunicacional en el diseño de moda es exponencial, por la cantidad de información en la era digital, por la interacción de los usuarios con las marcas a través de las redes sociales, por el tráfico creciente de productos de origen mixto (diseño, producción y distribución son mixtos). En este panorama, los discursos emergentes de los diseñadores conectados con realidades locales y de pensamiento crítico respecto a las identidades regionales cobran visibilidad y relevancia (Fraga, Juana de Arco, Giacobbe). También aquellas marcas de renombre global (como Levis, Nike y Uniqlo), que dialogan con los cambios profundos que atraviesan los comportamientos de los consumidores, logran desarrollos exitosos y significativos.

En virtud de lo expuesto cobra relevancia inusitada la frase de E. Morin: "Los analfabetos del siglo XXI no serán los que no sepan leer y escribir, sino los que no puedan aprender, 
desaprender y reaprender" (2011, p. 144). La idea retomada por Verón de una semiosis infinita, mutable y abierta, donde no hay punto de llegada preciso ni cierre (de la teoría de Pierce) es ilustrativa de la compleja interdiscursividad que enfrentan los diseñadores de indumentaria. Esto significa comprender la complejidad del sentido de los objetos que diseñamos y su relación con las experiencias, emociones, ideas y discursos que la indumentaria atraviesa, tanto en su proyectualidad como en el campo profesional.

\section{Notas}

1. El término tendencia es retomado de la categoría propuesta por el sociólogo F. Morace.

2. Serie emitida por Netflix (capítulos temporada 4).

3. Esta serie de prendas ultralivianas constituye un ejemplo de un producto altamente exitoso por un cambio no sólo estético sino de sentido en el campo del diseño.

\section{Bibliografía consultada}

Arfuch, L. y otros autores. (1997). Diseño y comunicación. Teorías y enfoques críticos. Buenos Aires: Editorial Paidós, estudios de comunicación.

Baudrillard, J. (1974). Crítica de la economía política del signo. México: Siglo Veintiuno Editores.

Baudrillard, J. (1969). El sistema de los objetos. Madrid: Editorial Siglo Veintiuno.

Bonsiepe, G. (1993). Del objeto a la interfase. Mutaciones del diseño. Buenos Aires: Ediciones Infinito.

Bourdieu, P. (2011). Cuestiones de sociología. Madrid: Editorial Akal.

Bourdieu, P. (2010). El sentido social del gusto. Elementos para una sociología de la cultura. Buenos Aires: Siglo Veintiuno Editores.

Davis, F. (1992). Fashion, culture and identity. Estados Unidos: Editorial University Chicago Press.

Faerm, S., Veneziani, M., Cuervo, M. comp. Fiorini, V. y otros autores. (2015). Interpretando el pensamiento de diseño del siglo XXI. Capítulo de mi autoría: Tendencias de consumo, innovación e identidad en la moda. Ed. Cuadernos del Centro de Estudios en Diseño y Comunicación (Ensayo).Buenos Aires, editado por la UP y Parsons New School for Design.

Lupton, E. (2012). Intuición, acción, creación. Graphic Design Thinking. Barcelona: Editorial GG Diseño.

Leiro, R. (2006). Diseño, estrategia y gestión. Buenos Aires: Ediciones Infinito.

Maldonado, T. (1977). El diseño industrial reconsiderado. "El proyecto moderno". Barcelona: GG Diseño.

Norman, D. (2005). El diseño emocional. Barcelona: Ediciones Paidos.

Tammela, J. (2016). A revolucáo do Design.Conexóes para o século XXI. Brasil, editado por IED. Verón E. (2004). Fragmentos de un tejido. Barcelona: Editorial Gedisa. 


\begin{abstract}
This article aims to address certain changes in the methodological models that are developed in the field of teaching the concept of project in Fashion. The impact of sociocultural transformations in consumer models, the emergence of other logics of message production and communicational discourses in the field of fashion are aspects that force us to revise the disciplinary conceptions in education in design and in the professional field. There are two key aspects that will be analyzed in this work: the ways of thinking and teaching the design and its resulting objects in their relationship with the consumer experiences they propose as a sign-value (Baudrillard). The contemporary, uncertain and fluctuating context also traces a panorama of high complexity. The emergence of local identities, in a highly globalized world, deserves to be revised, as it redefines the logic of the disciplinary field (Bourdieu) and the discourses that are legitimized in it (Verón).
\end{abstract}

Keywords: methodologies - project - design of clothing - models and experiences of consumption - education - communication - sign - discursivity - interdiscursivity.

Resumo: Este artigo tem como objetivo abordar algumas mudanças nos modelos metodológicos cos desenvolvido no campo do ensino do projeto em roupas. O impacto das transformações socioculturais nos modelos de consumo, a emergência de outras lógicas de produção de mensagens e discursos comunicacionais no campo da moda são aspectos que nos obrigam a rever as concepções disciplinares no design e no campo profissional. Existem dois aspectos-chave que serão analisados neste trabalho: as formas de pensar e ensinar o design e seus objetos resultantes em sua relação com as experiências do consumidor que eles propõem como valor -assinar (Baudrillard). O contexto contemporâneo, incerto e flutuante também traça um panorama de alta complexidade. O surgimento de identidades locais, em um mundo altamente globalizado, merece ser revisado, pois redefine a lógica do campo disciplinar (Bourdieu) e os discursos que são legitimados no mesmo (Verón).

Palavras chave: Metodologias - projeto - design de roupas - modelos de consumo e experiências - educação - comunicação - signo - discursividade - interdiscursividade.

[Las traducciones de los abstracts fueron supervisadas por el autor de cada artículo] 
Fecha de recepción: abril 2019

Fecha de aceptación: octubre 2019

Versión final: marzo 2020

\section{La enseñanza de la metodología de la investigación en la era de la invención: Hacia un nuevo humanismo}

Claudio Eiriz *

\begin{abstract}
Resumen: Parte del debate respecto de la enseñanza se circunscribe a la discusión acerca de la incorporación de las nuevas tecnologías en el aula y a la comprensión de la subjetividad de los alumnos en la actualidad (millennials). Los modos de interacción social están cambiando y en tanto los estilos de apropiación del conocimiento son tributarios de los modelos disponibles en la efectividad social, es natural que se interprete que los modos en que las nuevas generaciones se apropian del conocimiento, también esté cambiando. Sin embargo, el modo que le damos sentido a los efectos posibles de esa transformación, forman parte de la producción del cambio mismo. En esta ponencia se intenta reflexionar acerca del discurso respecto de los estilos de aprendizaje de las nuevas generaciones, los cambios que se han producidos a partir de las Tics y posteriormente en la consecuencia que estos cambios pueden traer en la enseñanza de la metodología de la investigación, haciendo especial énfasis en los contextos de descubrimiento e invención.
\end{abstract}

Palabras clave: Metodología - investigación - didáctica - nuevas tecnologías - diseño - pedagogía- contenidos - psicopedagogía - comunicación - sociología - conocimiento - millennials- creatividad- invención- humanismo- investigación.

[Resúmenes en inglés y portugués en la página 78]

${ }^{(*)}$ Músico, Psicopedagogo, Licenciado y Profesor en Ciencias de la Educación (UNLZ), Posgraduado en Semiología de la Música (UBA). Áreas de interés: Análisis de las relaciones entre la imagen y el sonido; Aculogía; Didáctica de la Música y Semio-Epistemología. Profesor de la Facultad de Diseño y Comunicación de la Universidad de Palermo, de la Facultad de Psicología de la Universidad Abierta Interamericana, de la Facultad de Psicología de la Universidad de Buenos Aires y de la Facultad de Kinesiología y Fisioterapia de la Universidad Juan Agustín Maza de Mendoza.

\title{
I. Un mundo en transición
}

"El viejo mundo se muere. El nuevo tarda en aparecer. Y en ese claroscuro surgen los monstruos” (Antonio Gramsci). 
Es indudable que estamos transitando un momento de cambios. Las páginas de las revistas, los portales de internet o las publicidades de las consultoras en e-learning a menudo nos advierten acerca del nuevo tipo de subjetividad de las jóvenes generaciones. Las tecnologías de información y comunicación (Tics) lo han trastocado todo. El tiempo, el espacio y las relaciones humanas ya no son lo que eran. Los modos de enseñar y aprender tampoco han quedado fuera de esta metamorfosis y en virtud de ello, proliferan las voces que proclaman la necesidad urgente de adecuar los sistemas educativos y las formas de enseñar al nuevo estado de las cosas.

Naturalmente no faltan los gurúes que hacen oír su optimismo. Para ellos cada cambio es una oportunidad. Es así como se venden cursos, capacitaciones y libros que nos prometen conocer el secreto al que debemos acceder para adecuarnos a un "Nuevo Mundo" que aún no ha llegado. Otros, menos optimistas, reconocen los cambios pero son más moderados, se limitan a formular algunas preguntas.

Las Tics han reflotado una vieja discusión en el ámbito educativo. Algo que desde hace décadas parece repetirse igual a sí mismo en todos los contextos.

Una serie de críticas recitadas hasta el hartazgo, ahora también por intelectuales y público de todo tipo, no son muy distintas a las que nosotros, alumnos de secundaria de los años 70 ya le hacíamos a la educación. A partir del advenimiento de las Tics las críticas parecieran haber cobrado un nuevo y vigoroso impulso.

Se vuelven a plantear el lugar que ocupan los intereses de los alumnos, el modo en que se dan las clases, el problema de la asimetría en las relaciones de poder, la validez de los contenidos a enseñar y su aplicabilidad en la efectividad social, entre otros asuntos.

"Nadie nos preguntó jamás por nuestros intereses y por nuestras necesidades" nos vuelven a decir los estudiantes. Bajo el influjo de las leyes del mercado se ha convertido al conocimiento en una mercancía: "La clase es el único negocio donde el cliente nunca tiene la razón", insisten.

"Antiguamente -escribe Serres- y hasta hace poco, enseñar consistía en una oferta. Exclusiva, semi- conductora, que nunca tenía el cuidado de escuchar la opinión ni las elecciones de la demanda" (2012, p. 18).

Este autor usa la metáfora de la vieja publicidad del gramófono para ejemplificar el modelo tradicional de las relaciones de comunicación entre maestros y alumnos ${ }^{1}$. El cuadro His Master's Voice de Francis Barraud reproduce la escena de un perro escuchando la "voz de su amo" a través de la Bocina del aparato. Pero ahora que los estudiantes se interesan cada vez menos por lo que el profesor dice la clase se ha convertido en un murmullo constante. Los cachorros ladran y los profesores se quejan.

¿Por qué pulgarcita ${ }^{2}$ se interesa cada vez menos por lo que dice el altoparlante? -Se pregunta Serres. Porque, ante la oferta creciente de saber en capa inmensa, por todas partes y siempre accesible, una oferta puntual y singular se vuelve irrisoria (...) La oferta sin demanda murió esta mañana. La oferta enorme que la sigue y la reemplaza refluye ante la demanda $(2012$, p. 19).

Para Serres, el saber está todo en la web y es cada vez es más accesible. ¿Por qué los alumnos habrían de interesarse por la pobre oferta, ya avejentada, que puede ofrecer un pro- 
fesor? La respuesta es: Ninguna, "Nadie tiene ya necesidad de esos portavoces de antaño, excepto si uno, original y raro inventa" (Serres, 2012, p. 18) ${ }^{3}$.

Solo para jugar un poco con las fechas, pensemos que en 1900, cuando apareció la publicidad de la Gramophon Company, Freud (Quien también planteara el concepto de transferencia) publicó La Interpretación de los sueños y Lyman Frank Baum, El maravilloso mago de $\mathrm{Oz}$ (ese cuento que habla sobre la transferencia). Si como plantea Serres el modelo His Master's Voice ha llegado a su final, El Mago de Oz ya no puede gobernar la ciudad Esmeralda a través de un parlante y detrás de un telón. Ya ningún alumno pareciera suponerle un saber. ¿Será posible la educación si no hay transferencia? Yo lo dudo. Sin embargo habrá que ver si no hay algún nuevo Amo que se ha escondido, ya no detrás de un telón o una bocina, sino dentro del teléfono móvil.

"La cuestión se planteaba cruelmente cuando era necesario desplazarse para descubrir un saber escaso y secreto. De aquí en adelante accesible, superabundante, cercano, incluso en pequeños volúmenes que Pulgarcita lleva en su bolsillo, bajo su pañuelo" (Serres, 2012, p. 19).

Pero la pregunta que hay que hacerse es ¿Qué posibilidades hay de que alguien tenga deseos de aprender si tiene la fantasía (ideológica) de tener todo a mano, sin mediación del otro al que le supone un saber secreto que aún se le hace inaccesible?

$\mathrm{O}$ a lo mejor Pulgarcita cree haberse metido a Oz (o a Dios) en el bolsillo. Y al parecer el filósofo Serres lo cree y lo suscribe con entusiasmo.

Los profesores nunca tratan de hacerlo entretenido, continúa el reclamo. En la era del Entertainment, todo conocimiento ya está pre-digerido como el alimento para bebés y a gusto del consumidor. Quedaron atrás y lejanos y nobles intentos de los centros de interés de la Escuela Nueva, o incluso sus versiones más reciente como la idea del conocimiento situacional, aquel que intentaba interrogar a los alumnos en tanto que sujetos (Edwards, 1988). ¿Cómo es posible competir con las series de Netflix? La fascinación que produce el espectáculo sólo es posible reproducirla en la institución educativa al precio de hacer circular la lógica del espectáculo mismo y no necesariamente la lógica de los contenidos de las disciplinas asignados para ser enseñados. Destituido el profesor de su lugar de saber no le queda otra opción que disfrazarse de actor de Stand Up o en el mejor de los casos de guionista, para atrapar la atención de los alumnos.

En la sociedad positiva -escribe Byung-Chul Han-, en la que las cosas, convertidas ahora en mercancía, han de exponerse para hacer desaparece su valor cultural a favor del valor de exposición. En lo que se refiere a este último, la mera existencia es por completo insignificante. Todo lo que descansa en sí se demora en sí mismo, ya no tiene ningún valor. Las cosas se revisten de un valor solamente cuando son vistas. La coacción de la exposición, que lo entrega todo a la visibilidad, hace desaparecer por completo el aura como "aparición de una lejanía". El valor de exposición constituye el capitalismo consumado y no puede reducirse a la oposición marxista entre valor de uso y valor de cambio. No es valor de uso porque está sustraído a la esfera del uso, y no es ningún valor de cambio porque en él no se refleja ninguna fuerza de trabajo. Se debe solamente a la producción de atención (2013, p. 11). 
Y la producción de la atención es algo muy distinto a la producción de la escucha ${ }^{4}$. La idea de que hay cosas que hay que hacer aunque no nos gusten (trabajo) porque servirán para un futuro está en crisis. La ha suplantado un goce sin mediación. No hay futuro porque no hay tiempo de espera ni tensión narrativa. El mundo cambia demasiado rápido y los conocimientos se adquieren para ser adquiridos, mostrados, abandonados y ser cambiados por otros al igual que los pañales descartables. Aunque como lo entiende este mismo autor:

La crisis de la época actual no es la aceleración, sino la dispersión y la disociación temporal. Una discronía temporal hace que el tiempo transcurra sibilante sin dirección y se descomponga en una mera sucesión de presentes temporales, atomizados. Con ello, el tiempo se hace aditivo y queda vacío de toda narratividad (Byung-Chul Han, p. 30).

A lo mejor el niño freudiano que arroja y recoge el carretel para inventar el tiempo (una suerte de proto-narración) ha muerto. ¿Estaremos saliendo del modelo His Master's Voice y entrando al modelo His Majesty the Baby ${ }^{5}$ no ya como una vez nos creímos ser, sino como aspiramos ser?

¿Para qué nos sirve aprender Integrales y derivadas, latín, trigonometría, las leyes de Mendel, la tabla de los elementos de Mendeleyev o la historia?

Si el conocimiento se ha convertido en una mercancía lo que se cuestiona es su valor de uso. Se reclama que este saber sea práctico, útil, que sirva para algo. Vale decir, que tenga inmediata aplicación para los requerimientos de un mercado de trabajo que, para colmo, es cada vez más efímero. Hasta las corrientes progresistas en educación proponen que el conocimiento sea útil para cada uno individualmente. El verdadero pedido es que el conocimiento que se imparte sea "a gusto del consumidor". Se espera lo mismo de los conocimientos que con los productos del modelo Toyotista: fabricación diversificada de mercancías a la carta a causa, por ejemplo, de la adaptabilidad para reprogramar velozmente la línea de montaje. Pero se podría objetar que lo que hay que aprender no es a manejar el vehículo, el modelo hecho a nuestro gusto, sino el modo en que se puede reprogramar la cadena de montaje. Si esto es así, se hace necesario saber muchas cosas que nada tienen que ver con la "distinción" de ese vehículo en particular. Enseñar a operar un determinado software es un conocimiento de bajo vuelo, es ese el conocimiento que rápidamente va a quedar obsoleto. Lo que va a ser menos perecedero es el saber lógico-matemático implicado en el diseño de software. Y eso puede ser tedioso, requerir gran esfuerzo y es a lo mejor poco divertido. Incluso alguien tendrá que saber matemáticas aunque no sea para aplicarlas al diseño de software. Solo saberlas porque si, para alguna vez, para nada...

Por otra parte se confunde el espécimen con la especie. Cuando pensamos en los contenidos que hay que impartir, se piensa en lo que una generación (la especie) necesita saber y lo recibe de la generación anterior. Está claro, el genoma cultural se transmite así: para todos. Nadie puede saber de antemano qué le va a gustar, que cosa va a apasionar a un individuo (el espécimen). Por lo tanto es algo injusta la crítica a una educación humanista, aquella que intenta formar en el conjunto de las ciencias y en las artes que son el patrimonio de la humanidad. A partir de ella cada sujeto tendrá a disposición un panorama 
bastante general como para que pueda democráticamente elegir su vocación. La idea de dar a cada quien lo que presuntamente necesita es muy parecido a programar genéticamente a un humano, una suerte de androide de diseño.

En todo caso si se pretende ser democrático, habría que hacer el intento de ayudar a cada estudiante a que se posicione de un modo original frente al saber disponible y no exigirle la tarea -casi hostil- de que se invente su propia dieta sin ser aun nutricionista.

$\mathrm{Al}$ homologar a los estudiantes con solipsistas prácticos en una transacción comercial de libremercado, se genera un conflicto en los niveles de integración. Insisto que la educación -aunque se haga por internet- es el traslado del conocimiento de las viejas generaciones a las nuevas. Entonces, importa poco si cada uno en forma individual se interese o no por trigonometría.

\section{Producción y reproducción del "Nuevo Mundo": Interregno}

Lo que resulta inquietante no es tanto el acontecimiento. No discuto que las cosas hayan cambiado, ni que en consecuencia haya que cambiar las formas de enseñanza. (Optimistas y pesimistas admiten los cambios) Lo que verdaderamente inquieta es el modo en que el acontecimiento mismo es interpretado.

Considero peligroso que la tipificación de las características de las jóvenes generaciones -bajo la rúbrica de millenials o pulgarcitas-, no pase de ser una creencia, un saber parcial y pobre, una mera abstracción (universal abstracto para Hegel), que en mejor de los casos solo sirve como categoría de segmentación de mercado. No estoy descalificando a las creencias, por el contrario, aquí las creencias adquieren toda su fuerza. Lo que estoy intentando plantear es que estas descripciones que se hacen a partir de esos rótulos impensados, si se las cree, quien lo hace, actúa conforme a ello. Esto hace que se estatuyan finalmente como un marco normativo para la enseñanza ${ }^{6}$.

Lo que preocupa es cómo esto impacta en los educadores, los que efectivamente -sin ser célebres como los gurúes- todos los días se enfrentan a la clase con la honesta intención de acomodar su tarea a este marco normativo supuesto. Esto cierra el círculo en la producción de un nuevo juego de lenguaje. Si nosotros creemos en esto, nosotros comenzamos a funcionar conforme a lo que creemos y finalmente lo que hacemos es producirlo. Esto es mucho más que la clásica profecía auto-cumplida. Es la ficción misma lo que estructura la realidad.

No pido rechazar la adecuación de las interacciones áulicas y los contenidos a las características de los alumnos. Lo que pido en principio, es revisar -por sólo dar un ejemplo- si la misma idea de millenials o pulgarcitas es válida para la totalidad del universo de jóvenes. ¿Son iguales las características y estilos de aprendizajes de los alumnos de la universidad de Stanford que las de los alumnos de Florencio Varela?? Está claro que existe una desigualdad en el acceso a las Tics, que se expresan en las desigualdades sociales. La mentada tríada de navegabilidad, usabilidad y accesibilidad no es igual para todos.

Por otra parte, si estamos en un mundo en transición ¿Cómo es posible saber cómo será el punto de llegada? ¿Qué sentido tiene plantear cambios en los modos de enseñar basados en algo que no sucedió aun? ¿Acaso el modo en que interpretamos el cambio que produ- 
cen las nuevas tecnologías en la subjetividad de las nuevas generaciones no forma parte de el modo que van a adoptar? ${ }^{8}$

El viejo mundo se muere y el nuevo aun no aparece. Dos culturas parecen yuxtaponerse: la cultura letrada y las ciberculturas.

Los medios digitales de comunicación -escribe Silvina Morelli- en sus distintos soportes y formatos, tienen algunas características comunes: La accesibilidad a la información disponible en ellos, la usabilidad o facilidad para acceder a los contenidos y la navegabilidad o simpleza en la propuesta de recorridos, con posibilidades de interacción (2017, p. 93).

Sin embargo, ante la pululación de información y para tener un verdadero acceso a los contenidos se hace necesario disponer de herramientas que nos permitan establecer con rigor su discontinuidad y su jerarquía. "Podemos decir -coincidiendo con Daniel Linkque asistimos a una crisis constitutiva en la cual la marca de lo nuevo es una suerte de sutura entre la cultura letrada y las ciberculturas" (Morelli, 2017, p, 94).

\section{III. ¿Todo está en internet?}

Me encuentro en Youtube con una entrevista a Manuel Castells. Este afirma que la escuela insiste en transmitir información y que en virtud de ello ha quedado obsoleta. "La información -según Castells- está toda en internet”. El centro de la entrevista lo constituye su crítica a la prohibición de los celulares o computadoras en las clases de las universidades. Castells presume que en sus clases todos los estudiantes están conectados, y este hecho sirve para que lo desafíen constantemente y en virtud de ello, se facilite la construcción del conocimiento mediante la interacción. A partir de esta actitud -y no sin una cuota de exacerbado optimismo- el piensa que sería posible romper las relaciones verticales de poder en la escuela. Es decir lo que antes llamamos modelo His Master's Voice.

En otros términos, Castells pretende que la escuela se constituya en una experiencia colectiva que no esté dominada por las identificaciones sostenidas por discurso del Amo. Loable intención, sino fuera porque este profesor pasa por alto, que si sus alumnos, en vez de chatear con amigos o poner me gusta en facebook, buscan información para producir conocimientos es porque él es Manuel Castells: el profesor famoso y mediático. Es decir, sus alumnos lo ponen en el lugar del ideal del yo, le suponen un saber. Es Oz que saltó del bolsillo de pulgarcita al telón de Pitágoras nuevamente. Castells quiere romper las relaciones verticales de poder en la escuela sin darse cuenta de que si sus clases funcionan es -tal vezporque él se encuentra atrapado en la misma estructura histórica que propone cambiar. En los tiempos que corren -continua explicando Castells- los estudiantes terminan aprendiendo la información que su profesor aprendió la semana anterior. "Los profesores históricamente están a un libro más adelante que los estudiantes" ironiza".

Afirma también que incluso "los estudiantes saben mucho más que los profesores porque están en internet". A él mismo los estudiantes lo desafían constantemente. "Oye lo que usted dice es preciso pero no es así hace 5 años". 
Sin embargo acordamos con Byung Chul Han que:

La intuición, por ejemplo, va más allá de la información disponible y sigue su propia lógica. Hoy se atrofia la facultad superior de juzgar a causa de la creciente y pululante masa de información. Con frecuencia, un menos de saber e información produce un más. La negatividad de dejar y olvidar tiene no pocas veces un efecto productivo. La sociedad de la transparencia no permite lagunas de información ni de visión. Pero tanto el pensamiento como la inspiración requieren un vacío. En alemán hay una relación entre laguna y dicha. Y una sociedad que no admitiera ya ninguna negatividad de un vacío sería una sociedad sin dicha. Amor sin laguna de visión es pornografía. Y sin laguna de saber el pensamiento degenera para convertirse en cálculo (2013, p. 7).

Además, en este tipo de razonamiento que Castells exponen en Youtube, que tiene como propósito el intento de democratizar las lógicas de las interacciones en el aula, que haga acallar a la figura del profesor Bocina, algo sigue haciendo ruido. Acaso que un profesor famoso y mediático desde el púlpito de los Best Sellers plantee con presuntos métodos hiper-democráticos lo que los alumnos y los profesores deben hacer ¿No es el discurso del amo en su máxima expresión?

\section{La fantasía ideológica}

Lo que sucede es que existe una ilusión de que la educación es un todo orgánico, Que puede haber una adecuación entre los requerimientos sociales y la transmisión de contenidos. El sistema educativo no es un todo congruente y siempre está estructurado en torno a una imposibilidad constitutiva. Siempre es un campo de conflictos.

Creer en la educación (o en la sociedad) como un todo orgánico (en una solidaridad orgánica) donde cada uno desde su lugar y de acuerdo a la función que tiene colabora con el todo, siempre supone que existe una parte de la los actores del sistema, una suerte de Alien, que corrompe al todo. En este caso la respuesta es intentar exterminar, sacar de cuajo a esta parte corrompida. Ha sido en otros tiempos los alumnos y sus familias, para las corrientes crítica, el sistema mismo y hoy los profesores que no se adaptan a las Tics. La educación seguirá siendo un campo de conflictos y mucho más en estos momentos en que estamos transitando un cambio.

En ningún otro punto de inflexión de la historia humana -concluye Zygmunt Bauman (2005) en su libro Los retos de la educación en la modernidad líquida- los educadores debieron afrontar un desafío estrictamente comparable con el que nos presenta la divisoria de aguas contemporánea. Sencillamente, nunca antes estuvimos en una situación semejante. Aún debemos aprender el arte de vivir en un mundo sobresaturado de información. Y también debemos aprender aún el más difícil arte de preparar a las próximas generaciones para vivir en semejante mundo

En resumen, no pocos plantean un cambio radical en los modos en que los jóvenes se apropian del conocimiento a causa de los cambios acaecidos desde que las nuevas Tec- 
nologías de información y comunicación han aparecido y a su turno ha transformado los modos de vinculación de los jóvenes con los otros y en consecuencia con los estilo de aprendizaje. Pero hay que tener en cuenta que al proclamar esto quienes lo sostienen forman parte de producción y reproducción de la realidad misma. El asunto al menos debe ser debatido.

\section{La revolución jamás vista en la historia}

Michel Serres articula la historia de la alianza entre el soporte y mensaje. Y en especial la historia de la objetivación de las facultadas (Memoria, imaginación Razón). O si se quiere, conforme a de la astucia razón hegeliana hicimos que algo exterior memorice, imagine y razone por nosotros.

Cuando no se había inventado la escritura el procesamiento de información, el almacenamiento (la memoria), la recepción y el envío de información (la voz), tenían como soporte la totalidad del cuerpo humano. En el primer milenio antes de Cristo aparece la invención de la escritura. El primer soporte -según Serres- exterior al cuerpo humano. Esta es la primera revolución que tendría como una de sus causas el cambio en el acoplamiento soporte- mensaje. Aparecen las ciudades debido a que las leyes escritas eran más estables (invención de los códigos del derecho escrito), consecuentemente la invención del Estado, invención de la moneda (que facilitó el comercio), la geometría, las religiones monoteístas, (las llamadas religiones del libro) y la Paideia (es decir la educación). Ya no era necesario saber a Homero de memoria, ahora estaba escrito.

Dos mil años más tarde aparece una segunda revolución concerniente a este acople entre soporte e información: la invención de la imprenta. Esta segunda tecnología que ocurre en Venecia, facilita la invención del cheque, del banco, la contabilidad, lo que llamamos Ciencia en el sentido más moderno, es decir experimental, y lo que más tarde se iría a llamar Capitalismo. También se produce la reforma protestante y la contrarreforma (cada quien podía de modo individual interpretar los textos sagrados, etc.). Va apareciendo aquí la idea de Yo y de las democracias en sentido moderno.

La conclusión que extrae de esto Serres es que, si ahora estamos inmersos en un nuevo cambio en el acoplamiento soporte - mensaje (Las nuevas tecnologías), debemos encontrar el mismo tipo de revolución. La regla que infiere es que cada cambio en la relación soporte - información produce una revolución en todos y cada uno de los ámbitos de la civilización tenemos que encontrar el mismo tipo de revolución. Es decir, tienen que estar afectadas todas las dimensiones de la cultura y la civilización. Esto queda verificado observando los cambios que se han suscitado en la efectividad social desde esta tercera revolución. La Globalización, las transformación del comercio y la moneda (la volatilidad de la moneda), crisis en la ciencia, y la crisis en la enseñanza y la educación serían prueba de ello.

La evolución histórica de la pareja soporte - mensaje es una buena variable de la función de enseñanza. De repente, la pedagogía cambió al menos tres veces: con la escritura, los griegos inventaron la paideia; tras la imprenta, pulularon los trabajos de pedagogía. ¿Hoy? (Serres, 2012, p. 10). 
Ya no necesitamos tener memoria porque está disponible en la Web, ya no necesitamos imaginación porque pululan las imágenes tampoco la razón, las computadoras hacen los cálculos que nosotros nunca podríamos hacer. ¿Qué queda entonces? Según Serres, lo que queda es la invención.

Serres para ejemplificarlo pone el énfasis en la memoria. Tanto la imaginación como la razón quedan un poco diluidas. Hay que hacer notar que al tomarlas como facultades pareciera en principio considerarlas como compartimentos estancos. ¿Qué le da unidad? ¿Qué las hace poner en danza?

Sin embargo las cosas se pueden pensar de otro modo. Es interesante esta reflexión acerca de la memoria de Byung Chul Han:

El exceso de positividad, que domina la sociedad actual, es un indicio de que ha perdido la narratividad. También la memoria queda afectada por ello. Su narratividad la distingue del acumulador, que trabaja de forma meramente aditiva y acumula. Las huellas de la memoria, en virtud de su historicidad, están sometidas a una constante reordenación e inscripción. En contraposición a esta reelaboración, los datos almacenados permanecen iguales a sí mismos. Hoy, la memoria se positiviza como un montón de residuos y de datos, como un "almacén de trastos", o un "depósito, que está lleno a tope [...] de todas las imágenes posibles y símbolos gastados, totalmente desordenados y mal conservados" [70]. Las cosas en el almacén de trastos se limitan a yacer unas junto a otras, no están estratificadas. Por eso le falta la historia. No puede recordar ni olvidar (2013, p. 29).

Serres -si lo he entendido bien- parece identificar la razón con el cálculo, la adición, el algoritmo. Si es así, todo el accionar humano ha sido depositado en un desván, letra muerta carente de toda narratividad (continuidad).

Volvamos a Byung-Chul Han:

La teoría de la negatividad está establecida antes que los datos e informaciones positivos, y también antes que los modelos. La ciencia positiva, basada en los datos, no es la causa, sino, más bien, la consecuencia de un final de la teoría, en el sentido auténtico, que se aproxima. La teoría no puede sustituirse sin más por la ciencia positiva. A esta le falta la negatividad de la decisión, que determina por primera vez lo que es o ha de ser. La teoría como negatividad hace que la realidad misma aparezca en cada caso y súbitamente de otra manera, bajo otra luz (2013 p. 8).

Acerca de la imaginación, también hay algunas cosas que no quedan muy claras. ¿Acaso la proliferación de imágenes es la imaginación misma? ¿O esto también es una fosa común de huesos inertes? ¿Qué es lo que la haría poner en funcionamiento, para hacer que las facultades humanas -aun objetivadas- a dancen en torno a la cosa comunal? "Los nuevos medios de comunicación -escribe Byung-Chul Han- no dan alas precisamente a la 
fantasía. Más bien, la gran densidad de información, sobre todo lo visual, la reprime. La hipervisibilidad no es ventajosa para la imaginación" (2014, p. 31).

\section{Hacia un nuevo humanismo}

Sin embargo, más allá de las dudas respecto de las ideas pedagógicas de Serres, asumiré que, si efectivamente hemos objetivado gran parte de las "musas" y ahora estamos más livianos, prestos a inventarlo "todo de nuevo", la invención deberá ser el centro de la organización de la Educación.

Todo el mundo sabe que en el Renacimiento retoma los cánones clásicos greco-romanos. Cada revolución pareciera volver a retomar algunos aspectos del pasado que en general habían quedado olvidados.

En esta nueva revolución, en este Renacimiento, a lo mejor debamos rescatar un pasado casi olvidado: el humanismo Italiano: ¿Por qué? Porque si seguimos a Serres, si efectivamente transitamos el advenimiento de la "era de la invención", es necesario abrevar el pensamiento en donde el ingenio y la invención y no la Razón deductiva han sido considerados como los principios ordenadores que motorizan el conocimiento. Es posible conjeturar que este antecedente se encuentra en el Humanismo Italiano. Sabemos también que fue Giambattista Vico quien coronó esta filosofía.

Hay que hacer notar que Vico confronta con Descartes el tema que aquí nos convoca: el de la invención.

La providencia aconsejó bien a las cosas humanas al promover en las mentes humanas antes la tópica que la crítica, igual que las cosas primero se conocen y después se juzgan. Pues la tópica es la facultad de hacer a las mentes ingeniosas, igual que la crítica es hacerlas exactas... (Vico, citado por Grassi, 1999, p. 14).

Vico identifica la doctrina de la invención con la filosofía tópica. De este modo, en términos retóricos, la inventio (tópica) precedería a la demostratio.

El ingenio es una facultad comprensiva, no usa la deducción, es la facultad de reunir en una sola las cosas separadas y distintas. Está relacionado a la metáfora (analogía) ${ }^{10}$.

El proceso racional deductivo cartesiano parte de, una vez descubierta una verdad primera, derivar el saber a partir de la deducción. Pero este presupone otra actividad. Esta actividad es la invención que necesariamente precede a la deducción. Hacemos notar como afirma Grassi que “...la estructura del conocimiento científico no se aleja de ese modelo. También quiere derivar todas las conclusiones posibles de una verdad primera, siguiendo el ejemplo de las matemáticas y la geometría...” (Grassi, 1999, p. 18).

En términos de metodología de la investigación el descubrimiento precede a la prueba. El contexto de descubrimiento precede al de verificación.

La facultad del Ingenio asume la función de proporcionar argumentos que el proceso racional no es capaz de descubrir por sí mismo. Vico define la facultad ingeniosa como un requisito del pensamiento metafórico (analógico). 


\section{Contextos de descubrimiento y contextos de verificación en la investigación}

Si lo aplicamos esta dicotomía entre pensamiento Tópico (inventio) y el Crítico (demostratio) al método de la ciencia tal como la entendemos en la actualidad podemos pensar que habría dos contextos dos modos de acción complementarios.

En general la epistemología ha tratado acerca del contexto de verificación es decir partiendo de una hipótesis, confirmarla o refutarla. Pero para ello es necesario tener alguna. Es decir hay un proceso que va de la identificación de algún problema expresado en una o más preguntas para, de este modo, proceder a elaborar una hipótesis (o teoría) que dé respuesta, de modo tentativo, a la pregunta formulada ${ }^{11}$.

De ello se infiere que además de un contexto de verificación de una hipótesis, es insoslayable que haya un proceso de descubrimiento (o invención) de la misma. Este proceso se lo denomina Contexto de descubrimiento. Y es mi creencia, que en este contexto se ponen en juego las operaciones necesarias para la invención. Allí la ciencia se parece al arte y al diseño.

El contexto de verificación (la demostratio) opera con la deducción que está destinada a predecir y con la inducción, que está destinada a corroborar o refutar la teoría (o en términos popperianos, a falsarla) si ésta fracasare en su capacidad predictiva. Estas operaciones parecerían no agregar nada nuevo; sino que sólo se constituyen como prueba de validez de lo que gracias a la aplicación las operaciones constitutivas del contexto de descubrimiento se ha generado.

Creemos que el contexto de descubrimiento (inventio), opera con otro tipo de inferencias lógicas. Así como el contexto de verificación operaba conforme a la deducción y la inducción, el contexto de descubrimiento opera con la analogía y la abducción. La analogía (metáfora, pensamiento tópico) estaría al servicio de acotar el campo de búsqueda, si fuera el caso de carecer de alguna explicación y respuesta posible al problema planteado. La abducción está al servicio de proporcionar interpretaciones provisorias a título de hipótesis de trabajo.

\section{La invención tiene razones que la razón no conoce}

Ante la irrupción de algo que nos parece inexplicable y nuestros saberes previos no alcanzan, cuando no tenemos una regla, un modelo, unos esquemas de asimilación que haga que un fenómeno sea inteligible, nos preguntamos cómo ingeniárnosla para construirlos. Postularemos aquí que para acceder a los esquemas que nos permitirían comprender lo extraño no procederemos ni de la mera observación (inductivismo), ni de alguna "misteriosa facultad" (Eurekismo), ni de la pura razón (deductivimo). Si es posible encontrarle alguna forma de comprensión, ésta procede de la vida misma: de la praxis. La génesis del conocimiento acerca de la "realidad" -es decir la invención de las teorías- es del orden de la producción: los procesos productivos humanos se transforman en los modelos con los que nos apropiamos del mundo: "Resultan de la producción y se expresan como apropiación” (Samaja, 2000, p 106). 
Esto podría contestar a la pregunta de cómo es posible, o cual es la lógica de los contextos de descubrimiento. Ya sabemos que una hipótesis o un grupo de hipótesis o una teoría no se descubren por adivinación. Ha de haber alguna lógica en la invención. ¿Cómo es posible el conocimiento de una parcela de la realidad?

Stephen Gould $(1986 ; 2006)$ hace una exploración acerca de cómo Darwin construyó su teoría de la selección natural. Este constituye un Caso lo suficientemente significativo del cual se podrían sacar algunas pistas para entender la lógica de la invención.

La teoría de la selección natural no surgió ni como inducción elaborada a partir de los datos de la naturaleza, ni como un misterioso relámpago de iluminación procedente del subconsciente de Darwin, detonado por una lectura fortuita de Malthus. Emergió, por el contrario, como resultado de una búsqueda consciente y productiva, que procedió de un modo ramificado pero ordenado, y que utilizó tanto los datos de la naturaleza como el abanico asombrosamente amplio de percepciones procedentes de disciplinas muy dispares y alejadas de la suya propia. Darwin recorrió el camino de en medio entre el inductismo y el eurekismo. Su genio no es ni pedestre ni inaccesible (Gould, 2006, p. 25).

Según Gould, Silvan S. Schweber en su trabajo "The Origin of the Origin Revisited", Journal of the History of Biology (1977) reconstruyó minuciosamente por medio una serie documentos existentes argumentando que las piezas finales de su teoría no surgieron de nuevos en la historia natural, "sino de los vagabundeos intelectuales de Darwin por campos muy distantes" (2006 p. 25).

Darwin por esos tiempos leyó un resumen el Cours de philosophie positive de Augusto Comte. Este lo atrajo por la insistencia de Comte en que una teoría debía ser predictiva y potencialmente cuantitativa.

También se interesó en Adam Smith, y:

(...) se embebió de la creencia básica de los economistas escoceses de que las teorías sobre la estructura social global deben empezar por analizar las acciones no reprimidas de los individuos (La selección natural es, por encima de todo, una teoría acerca de la lucha del organismo como individuo por su éxito reproductivo) (2006. p. 25).

Buscando la cuantificación, se interesó por un largo análisis del trabajo realizado por el estadígrafo belga Adolphe Quetelet. En las reflexiones de este autor se refrendaba categóricamente el planteamiento de Malthus: la población crecería geométricamente y los suministros de alimentos lo harían sólo aritméticamente, asegurando así una intensa lucha por la supervivencia. El aporte de Darwin no fue el apoyo a la idea de la evolución sino una explicación de su mecanismo.

La teoría de la selección natural es una transferencia creativa a la biología de la argumentación básica de Adam Smith en favor de una economía racional: el equilibrio y el orden de la naturaleza no surgen de un control más elevado 
y exterior (divino), o de la existencia de leyes que operen directamente sobre la totalidad, sino de la lucha entre los individuos por su propio beneficio (en términos modernos, por la transmisión de sus genes a las generaciones futuras a través del éxito diferencial en la reproducción) (Gould, 2006, p. 26).

Que sea una transferencia de una teoría económica que muchos consideramos solo una fantasía ideológica, eso no es óbice para que su estructura transferida a otro campo no sea una analogía válida ${ }^{12}$.

\section{La analogía}

Pero hay más, como todos sabemos, el primer capítulo de El origen de las especies, está enteramente dedicado a la selección artificial.

"Me limito a aseverar, que Darwin tenía justificadas razones para establecer la analogía entre la selección natural y la cría de animales. En la selección artificial, los deseos del criador representan un 'cambio en el medio ambiente' de una población" (Gould, 1983, p. 27). Digamos que para Darwin la adaptación constituía un rasgo omnipresente en los seres vivos, pero no disponía de ninguna hipótesis que diera cuenta de la misma. Sabía que la población crecería geométricamente y los suministros de alimentos lo harían sólo aritméticamente (Malthus) y que había una lucha, que no es otra cosa que la lucha por la reproducción. Conocía además la selección artificial, es decir, la adaptación, por manipulación de los granjeros de los animales de granja conforme a los requerimientos del mercado. Para abordar el problema de crear una hipótesis que explicara la adaptación en general, Darwin no lo hizo ni por medio de la deducción (racionalismo), ni por inducción (empirismo), tampoco por Eurekismo, sino que necesitó - para acotar las infinitas hipótesis posibles- recurrir a una analogía, es decir, ir de un todo orgánico conocido (la selección artificial) a un todo orgánico desconocido (la selección natural) que pone en relación por cierta semejanza en sus determinaciones. Fue la Musa Erato la que lo ayudó a encontrar lo semejante.

Ateniéndonos a lo antes expuesto la génesis del conocimiento, su invención -e incluso su potencia explicativa- es posible que tengan su antecedente histórico en algunas tesis del humanismo, aquel que dije que culminó con Vico (y que podríamos llamar el constructivismo historicista) y en especial en el sentido que los humanistas le dieron a la metáfora - (analogía.)

La tesis de Vico se podría sintetizar así: "Si yo lo hago, entonces yo lo conozco en su verdad", Verum ipsum factun (lo verdadero es lo mismo que lo obrado). En otras palabras, lo conozco verdaderamente, sólo y sólo si lo conozco en su estado de génesis (Samaja, 1996). Esta tesis también se refiere a que los procesos de producción se constituyen en los modelos con los que nos apropiamos del mundo. Siempre necesitamos construirnos una regla, unos esquemas. Esos esquemas están siempre en los modos en que los hombres operamos con los objetos del mundo y en las interacciones sociales efectivas. Y de allí su legitimidad: la reglas operatorias (la hipótesis o teorías) que utilizamos para comprender el mundo, nosotros mismos las hemos inventado, interactuando con ese mismo mundo. 
Insisto: ¿Por qué esta hipótesis derivada de la analogía con la granja (la naturaleza funciona como una granja) tiene legitimidad? Porque las reglas operatorias (las hipótesis o teorías) que utilizamos para comprender el mundo, las hemos inventado hace miles de años: ya estaban presentes en la efectividad social.

Es cierto que aun no estaría completo el cuadro de las operaciones (o inferencias) que explicarían en términos generales la "Logica" de la invención.

\section{La abducción}

Se hace necesario también pensar -aunque por razones de espacio lo haré de manera muy sucinta- en una inferencia un tanto compleja de entender que es la Abducción.

Dentro de las inferencias clásicas podemos contar con la deducción, la inducción, la abducción y la analogía. En general las últimas dos fueron tomadas por los lógicos como falacias. Sin embargo, en lo concerniente a la invención, al contexto de descubrimiento estas son válidas. La abducción está al servicio de proporcionar interpretaciones provisorias a título de hipótesis de trabajo.

Ahora veamos la abducción en el caso de Darwin:

En la abducción ya tenemos la Regla y tenemos los rasgos (En términos silogísticos: la premisa superior y la conclusión) lo que necesitamos obtener es el Caso.

$\mathrm{R}-\mathrm{r}=\mathrm{C}$

Mediante un paso de analogía se había podido extraer la Regla. Se partía de la granja como hecho singular, sin necesidad de recurrir a ningún tipo de inducción puesto que conocemos como realizar la selección artificial porque nosotros mismos la hemos inventado y funciona. La granja es universal concreto (Hegel) y su la regla no es otra cosa que la explicitación de su sistema operatorio. En otras palabras: nuestras acciones en tanto que grajeros. "La granja produce seres vivientes conforme a fines (es decir, "seres adaptados") mediante selección doméstica y acumulación de variaciones" (Samaja, 2004, p. 105).

La idea de que la naturaleza es como una granja es el producto de una facultad de captar la semejanza (metáfora-analogía para los Humanistas Italianos) entre algo conocido y algo desconocido. Es decir, captar la semejanza entre la granja y la naturaleza. La naturaleza es como una granja

El silogismo seguiría de este modo:

"El mecanismo de adaptación en la granja es selectivo" (Resultado del Análogo).

"El mecanismo de adaptación en general es selectivo" (Regla del analogado).

"La naturaleza presenta seres vivientes adaptados" (Resultado en sentido propio).

Conclusión

“La naturaleza es un caso de evolución por selección” (Caso) (Samaja, 2004, p. 108). 
Si bien son cuatro y no tres términos, es fácil advertir que la regla del análogo se identifica con la regla del analogado. Por lo tantos son tres términos.

$\mathrm{R}-\mathrm{r}=\mathrm{C}$ (abducción)

Es decir que la lógica de la invención -tal como traté de demostrar-en principio responde a estas dos inferencias: la analogía y la abducción.

\section{Conclusión}

Retomemos los planteos del inicio de este escrito. ¿Es posible la enseñanza, al menos de algunas parcelas del conocimiento, como por ejemplo el de la metodología de la investigación, cuyos procesos cognitivos parecen ser contrarios a las presuntas características e intereses de nuestros jóvenes? A lo mejor aquello que Serres plantea acerca de la invención ya formaban parte de la ciencia, incluso desde su origen. O en otras palabras, la invención tiene una lógica tan compleja como la puesta a prueba de hipótesis. Aunque hayamos objetivado la memoria y ciertas operaciones de cómputos; aunque las máquinas lo hagan mejor que nosotros, los procesos de invención requieren de operaciones lógicas y poéticas complejas y de amplios conocimientos en variados campos del saber. Es en esa cantera de conocimientos donde seguiremos abrevando para encontrar analogías que nos permitan hacer inteligibles aquello que hoy desconocemos. Se cuenta que Thomas Kuhn había sido invitado a una Universidad a dar una disertación sobre la creatividad. El público esperaba que hablara de algún tipo de forma de pensamiento, como el pensamiento lateral o alguna cosa por el estilo. Sin embargo Kuhn concluyó: ¿Ustedes quieren formar personas creativas? Formen Humanistas, personas idóneas en las ciencias, filosofía, historia y artes.

Hoy más que nunca, para inventar, es necesario saber de todo. Lo demás está en Internet.

\section{Notas}

1. La publicidad del gramófono fue difundida por la Gramophone Company.

2. "Escriben de otra manera. Al observarlos, con admiración , enviar más rápidamente de lo que yo nunca podría hacerlo con mis gordos dedos, enviar (digo) SMS con sus dos pulgares, los he bautizado -con la más grande ternura que pueda expresar un abuelo- Pulgarcita y Pulgarcito. Este es un nombre, más bonito que la vieja palabra, seudo-científica, de dáctilo" (Serres, 2012, p. 8).

3. El destacado es mío. Más adelante veremos que la idea de "invención” es lo que ordena esta ponencia.

4. Barthes (1986) para dar cuenta de este fenómeno hace referencia al "Fort-da" del niño freudiano; ese juego que consiste en arrojar y recoger un carretel atado a un hilo, en que el niño remeda la presencia y la ausencia de la madre. Aquello que sufría pasivamente lo transforma -activamente- creando así el primer juego simbólico, al tiempo que crea ritmo. Ese niño que estaba a la expectativa (atento) de los ruidos que anunciaran la llegada de la madre, se reconfigura por medio de este juego en signo. Lo escuchado ya no es lo 
posible (Una amenaza o el objeto de deseo que pasa sin avisar) -dice Barthes- ahora la escucha se convierte en lo secreto. "Lo que sumergido en la realidad, no puede advenir a la conciencia humana sino a través de un código" (247). Digamos que lo que se intenta captar con los oídos son signos "escuchamos como leemos, es decir de acuerdo a ciertos códigos" (243). Es decir, el inicio de una narrativa.

5. Es posible que la referencia de Freud a "His Majesty the Baby" esté inspirada en un cuadro. https://historiasdelpsicoanalisis.wordpress.com/2013/01/29/el-misterioso-pintor -edwardiano-y-his-majesty-the-baby/

6. Si yo creo que los jóvenes estudiantes no leen, yo voy a poner menor cantidad de bibliografía en mi cátedra. Al tiempo los jóvenes estudiantes no van a leer. Ya no se sabe pues si es por una característica intrínseca de las jóvenes generaciones o porque yo mismo sembré el terreno para que florezca esa cultura.

7. Localidad del conurbano de la provincia de Buenos Aires, Argentina.

8. Con frecuencia al postular estos seudo -conceptos que se refieren a una cosa, hecho o proceso no se tiene en cuenta que tal referente es el efecto de una de relaciones entre éste y otros conceptos conexos, y se lo suele presentar como fuera de la relación misma. En consecuencia, ese referente siendo como ya "en si", fuera de la relación con los otros, es presentado como si fuera una propiedad "natural". Además suele ocurrir que quien la postula -en general un académico reconocido- se excluye del lugar que le toca en la red de interacciones simbólicas. En el caso de la educación esto es palpable, porque según nosotros interpretemos las características de los alumnos -si somos honestos- vamos a programar una clase conforme a ello. Esto hace que los diagnósticos tengan que ser revisados una y otra vez, puesto que al formar, formamos parte de esa estructura de reproducción (y producción).

9. Este autor mismo constituye prueba de lo que dice puesto que las opiniones que vertió acerca de la educación están a varios libros por detrás de los estudiantes, o mejor, a 50 años de distancia.

10. Coluccio Salutati (1331-1406) en "Los trabajos de Hércules" explica la función de la Musa Erato en relación a las otras ocho musas. Erato es quien transfiere lo semejante a lo semejante. Hoy hablamos de paso de analogía. Mas hasta aquí no es instruido en las cosas de las que entiende, quien no sabe hacer brotar la invención en medio de lo semejante. ¿Qué es pues lo que solo se apoya en lo engendrado y no inventa nada que merezca tal esfuerzo, o al menos una imitación de lo comprendido y se transfiere de lo semejante a lo semejante? Erato ocupa luego el sexto lugar, (...) es la que encuentra lo semejante. (Traducción CE) https://www.hs-augsburg.de/ harsch/Chronologia/Lspost14/Salutati/s al_h109.html

11. La llamada epistemología Hipotético-deductiva que propuso Karl Popper en 1934 y que tiene actualmente gran aceptación, ha presentado un esquema sumamente exitoso para comprender la operación de la mente humana cuando ella se enfrenta a un problema de conocimiento. Un problema, en la perspectiva popperiana, debe ser enfrentado con una hipótesis (o teoría) y ella no se establece mediante ningún procedimiento lógico sino mediante una creación cuyo mecanismo escapa a toda investigación lógica y metodológica (Samaja, 1996, p. 22). Es decir que para Popper no hay método para el contexto de descubrimiento. Lo que sigue en esta ponencia es un intento de convencer de que si hay una 
"lógica" en la invención. Aprovecho para decir que todas estas apreciaciones que siguen en este escrito tienen su origen en varios de los escritos del Doctor Juan Samaja.

12. 1902: "El hecho de que una idea emane de una clase en particular, o esté de acuerdo con sus intereses, no prueba, por supuesto, nada acerca de su verdad o falsedad". En este caso resulta irónico que el sistema del laissez-faire de Adam Smith no funcione en su propio terreno de la economía, ya que lleva al oligopolio y la revolución y no al orden y la armonía. No obstante, la lucha entre los individuos parece ser ley de la naturaleza (Gould, 2006, p. 26).

\section{Bibliografía}

Barthes, R (1986). Lo obvio y lo obtuso: imágenes, gestos, voces. Buenos Aires. Paidós. Bauman, Z. (2005). Los retos de la educación en la modernidad líquida. Barcelona: Gedisa. Edwards, V. (1988). Los sujetos y la construcción social del conocimiento en primaria: un estudio Etnográfico. Buenos Aires: Paidós.

Gould, S. (1983). Desde Darwin: Reflexiones sobre historia natural. Madrid: Hermann Blume Ediciones.

Gould, S. (2006). El pulgar del panda. Barcelona: Editorial Crítica S.L.

Grassi, E. (1999). Vico y el Humanismo. Ensayos sobre Vico, Heidegger y la retórica. Barcelona: Antrhopos.

. (2001-2002). El comienzo del pensamiento moderno: de la pasión y la experiencia de lo originario. Cuadernos sobre Vico, 19-46. Recuperado de http://institucional. us.es/revistas/vico/vol.13-14/2.pdf

Han, B.-C (2013). La sociedad de la transparencia. Athamasha. Recuperado de https:// editorialatamansha.files.wordpress.com/2015/12/la-sociedad-de-la-transparencia.pdf

. (2014). La agonía del Eros. Barcelona: Herder. Recuperado de https://cursos luispatinoffyl.files.wordpress.com/2014/01/byung-chul-han_la-agonc3ada-del-eros.pdf

Morelli, S. (2017). Gestión, política y comunicación. Buenas prácticas en la implementación de proyectos municipales. Buenos Aires: Ugerman Editor.

Salutati, C. De laboribus Herculis. libri IV. Biblotheca Agustana. Recuperado de https://www. hs-augsburg.de/ harsch/Chronologia/Lspost14/Salutati/sal_h000.html

Samaja, J. (1996). La bolsa y la especie. Para volver a pensar el sistema de la abducción en el sistema de inferencias. Revista científica de la Facultad de Bellas Artes de la Universidad Nacional de La Plata. 21- 35. Está indicado Año 1, Número 1. . (1998). El lado oscuro de la razón. Buenos Aires: JVE editores. . (2000). Semiótica y dialéctica: seguido de la Lógica breve de Hegel. Buenos Aires: JVE editores . (2004). Epistemología y metodología: elementos para una teoría de la investigación científica. Edición ampliada. Buenos Aires: Eudeba.

Serres, M. (2013). Pulgarcita. Recuperado de http://uruguayeduca.edu.uy/sites/default/ files/2017-05/pulgarcita.pdf 


\title{
Medios audiovisuales
}

Entrevista a Manuel Castells. Recuperado de https://www.youtube.com/watch?v=eb0cNr E3I5g\&list=PLTpzsjyse9ZFeQOoge2vi2jBBSbuRfQmp

Michel Serres. Las nuevas tecnologías, revolución cultural y cognitiva. Recuperado de https://www.youtube.com/watch?v=8qh44YFczto

\begin{abstract}
Part of the debate regarding teaching is limited to the discussion about the incorporation of new technologies in the classroom and the understanding of the subjectivity of current students (millennials). The modes of social interaction are changing and as the styles of appropriation of knowledge are tributary to the available models in social effectiveness, it is natural that the ways in which new generations appropriate knowledge, is also changing. However, the way we make sense of the possible effects of that transformation is part of the production of the change itself. In this paper we try to reflect on the discourse regarding the learning styles of the new generations, the changes that have been produced from the Tics and later on the consequence that these changes can bring in the teaching of the research methodology, placing special emphasis on the contexts of discovery and invention.
\end{abstract}

Keywords: Methodology - research - didactics - new technologies - design - pedagogy contents - psychopedagogy - communication - sociology - knowledge - millennials - creativity - invention - humanism - research.

Resumo: Parte do debate sobre o ensino está circunscrito à discussão sobre da incorporação de novas tecnologias na sala de aula e para a compreensão da subjetividade dos estudantes hoje (millennials). Os modos de interação social são mudando e enquanto os estilos de apropriação do conhecimento são tributários do modelos disponíveis na eficácia social, é natural que os modos sejam interpretados em que as novas gerações se apropriam do conhecimento, também está mudando. No entanto, a forma como damos sentido aos possíveis efeitos dessa transformação, eles são parte da produção da mudança em si. Neste artigo, tentamos refletir sobre o discurso em relação aos estilos de aprendizagem das novas gerações, o mudanças que foram produzidas a partir dos Tics, posteriormente, na consequência que essas mudanças podem trazer o ensino de metodologia de pesquisa,com especial ênfase nos contextos de descoberta e invenção.

Palavras chave: Metodologia - pesquisa - didática - novas tecnologias - design - pedagogia - conteúdos - psicopedagogia - comunicação - sociologia - conhecimento - millennials criatividade - invenção - humanismo - pesquisa.

[Las traducciones de los abstracts fueron supervisadas por el autor de cada artículo] 
Fecha de recepción: abril 2019 Fecha de aceptación: octubre 2019 Versión final: marzo 2020

\section{Educar para no competir. La guerra de las naciones: nuevo escenario multipolar e innovación social como alternativa de adaptación}

Mercedes Buey Fernández *

\begin{abstract}
Resumen: En un mundo cambiante y globalizado, que pide a gritos innovación, identidad y significado, pareciera ser que aquellos que esperan que el mundo se ajuste a sus cálculos y predicciones están destinados a ser frustrados. Históricamente los cambios han dado miedo porque lo desconocido asusta. Sin embargo, la vida hoy se muestra intrínsecamente cambiante, conmovedora, decepcionante y sorprendentemente positiva. En este sentido, vivir una vida de expectativas inflexibles es una receta al desastre (Asma, 2017). En definitiva, las reglas y estructuras no son creaciones divinas, ¿qué se hace cuando caen las estructuras donde se vivió toda una vida?

El mundo se encuentra hoy sumido en tiempos de cambios drásticos. Las potencias se debilitan, las masas se dispersan y la tierra llora. Pero la humanidad ya no teme al cambio, busca el cambio; el seguidor de reglas se frustra y el improvisador se adapta.
\end{abstract}

Palabras clave: sociología - globalización - cultura - debate - diseño - innovación - actualidad.

[Resúmenes en inglés y portugués en las páginas 89-90]

${ }^{(*)}$ Diseñadora Industrial (UP). Profesora de la Universidad de Palermo en el Área de Diseño de Objetos y Productos de la Facultad de Diseño y Comunicación desde 2012. A lo largo de su trayectoria se desempeñó como diseñadora senior y semi senior en diferentes empresas. Desde 2012 es socia gerente, diseñadora y fundadora de Estudio De Raíz S.R.L. y Yerba Mate Mathienzo, fue docente evaluadora de Proyectos de Graduación; es especialista en Gestión de Diseño (UBA) y asistente externa en el área de estudios ergonómicos y capacitaciones de diferentes empresas.

\title{
Introducción
}

En un mundo cambiante y globalizado, que pide a gritos innovación, identidad y significado, pareciera ser que aquellos que esperan que ese mundo se ajuste a sus cálculos y predicciones están destinados al desastre total. A lo largo de los años, la respuesta a las cuestiones de agenda humana parecía permanecer invariable. Los sucesos eran acciones encadenadas de la naturaleza a las que la humanidad se enfrentaba sin cuestionar causales, o al menos esa era la concepción reinante. 
Sin embargo, la humanidad hoy descubre cosas asombrosas.

El escenario económico, político, geográfico y social está cambiando y esto impacta e importa a todos por igual. Desde principios del siglo XXI los cambios se presentan de manera vertiginosa, de toda índole y las cuestiones de agenda ya no son hechos incontrolables de la naturaleza, para pasar a ser cuestiones manejables, la incidencia de diferentes calamidades ha disminuido y cuando alguna parece salirse de control, enseguida alguna fuerza organizativa logra dominarla. Las estructuras hasta ahora conocidas se desmoronan, los límites y las fronteras se desdibujan, la tierra llora y pide a gritos un cambio actitudinal. Las políticas proteccionistas, la cuestión migratoria y las guerras modernas -luchas indiscriminadas por el poder, que esconden motivaciones económicas y/o geoestratégicas, detrás de una falsa búsqueda de la liberación y patriotismo- hacen que la vida se muestre hoy intrínsecamente cambiante, conmovedora, decepcionante y sorprendentemente positiva (Asma, 2017).

En líneas muy generales, el Brexit ha debilitado a la Unión Europea, el terrorismo islámico es una amenaza para occidente y Rusia está emergiendo como nueva potencia. Los analistas y expertos en geopolítica afirman que en los próximos años China será la primera superpotencia, la economía de Brasil pasará del noveno al cuarto lugar en el plano internacional y países como México, Vietnam o Indonesia podrían desarrollarse significativamente (Javier Navarro, 2017).

Sin embargo, ese crecimiento está supeditado, en gran medida, a un crecimiento económico y tecnológico que nos proporciona lo necesario para la supervivencia humana-comida y medicinas por ejemplo-, pero desestabiliza el equilibrio geo-ecológico del planeta de muchísimas maneras. Los avances en la brecha tecnológica han afectado y han conseguido cambiar el ecosistema global de formas radicales y sin precedentes.

Como actores principales de este mundo en clara transición el interrogante más fuerte sea seguramente ¿cómo navegar en estas aguas turbulentas?, ¿qué exigirá la atención en este nuevo marco coyuntural?, y, más precisamente: ¿cómo van a reflexionar y adaptarse los profesionales, a nuevos modos de comunicación y diseño, de manera tal que el público sienta empatía con el trabajo realizado y se llegue a una identificación y entendimiento pleno?

Autores como Harari (2017) se animan a delimitar la nueva agenda humana y en su análisis afirman que hace años el saber humano aumentaba despacio, de modo que la economía y la política cambiaban también a un ritmo pausado. Hoy, el crecimiento se da a una velocidad de "vértigo", y lo que en la teoría significaría que deberíamos entender al mundo cada vez mejor, en la práctica el presente se muestra demasiado distinto al pasado, y la capacidad de dar sentido a ese presente o de pronosticar futuro, como él sostiene, o estudiar el pasado, sólo encuentra justificación en el afán de "no repetirlo, de liberación". En definitiva, "el estudio de la historia no nos dirá qué elegir, pero a al menos no dará más opciones" (p. 74).

Por esto, todas las predicciones esbozadas en este ensayo se hacen eco de su visión y no pretenden ser otra cosa más que un dedicado intento de analizar sucintamente los dilemas actuales e invitación a cambiar el futuro, no tanto como una profecía, pero como una forma de analizar las opciones (Harari, 2017, p. 80). Hacer un análisis de contexto y predecir que el mundo está en transición y que esa transición es el resultado de la búsqueda de un 
fin común, resulta algo obvio, pero sólo se pueden pensar alternativas una vez que uno se enfrenta directamente a esos dilemas actuales.

El objetivo entonces, es lograr mejores decisiones, no mejores predicciones. Lo que las transforma a veces en pronósticos acertados no es que ellos como especialistas tengan la capacidad de prever el futuro, sino que lo que los hace verdaderamente buenos es que se ocupa de mirar el presente con mayor detenimiento (Evans, 2007).

¿Qué utilidad tendría si no, el nuevo conocimiento, más que el de llevar a uno a desarrollar comportamientos nuevos? No se pretende con esto hacer futurología, ni se pretende aquí vaticinar pronósticos, sencillamente porque como se expuso más arriba: el presente es muy distinto al pasado y los cambios se suceden a ritmos vertiginosos y de manera inesperada. Históricamente los cambios han dado miedo porque lo desconocido asusta. Sin embargo, vivir el cambio más que esperar para analizarlos, pareciera ser el modo de obrar que rige. Hoy ya no hay tiempo para ver cómo se acomodarán los límites y jugadores del nuevo mapa geopolítico. La humanidad no tiene tiempo de esperar para revisar y comenzar a reescribir la historia. La escribe mientras los hechos se suceden, incluso sin darse cuenta del peligro que eso podría conllevar para con la humanidad misma.

En este sentido, un proyecto central será proteger a la humanidad y al planeta en su conjunto de peligros inherentes a su propio poder. Hasta ahora aumentar el poder humano se basaba principalmente en mejorar las herramientas externas, aumentar la red de conexiones, $y$ afianzar las interrelaciones pero, en un futuro, las mejoras en las condiciones internas, el aumento del conocimiento y la descentralización serán la base de todo poder. (Harari, 2017). Porque si hasta ahora la humanidad se definió por lo externo, global y lo universal, de ahora en más se va a definir por una búsqueda de ética ulterior, unido a conceptos tales como tejido social, territorio, ciudadanía, diversidad cultural, paz y hasta el concepto de resiliencia. Los factores clave que servirán de argumentación para el debate serán la desigualdad y la migración; y la meta será lograr un impacto inclusivo.

\section{Nuevo mapa geopolítico: ¿Fin de la globalización?}

Las diferentes investigaciones muestran que el mundo está mucho menos concentrado que en los años ochenta, y que ha crecido constantemente desde las últimas dos décadas, impulsado principalmente por el crecimiento de China como se mencionaba anteriormente. Cuando Estados Unidos y la URSS lideraban el escenario político internacional, el mundo se dividía en dos bloques claramente diferenciados. Había dos ideologías antagónicas, el sistema democrático de los países occidentales liderados por Estados Unidos frente al modelo comunista de partido único que impuso la URSS en toda Europa oriental.

Desde un punto de vista económico, tomando en análisis preexistentes, Estados Unidos y sus países aliados impulsaron un modelo capitalista basado en el libre mercado y el bloque soviético mantuvo una economía planificada y basada en la intervención estatal. Con la desintegración de la URSS, parecía inicialmente que el mundo tendría una única superpotencia: Estados Unidos. Pero, este país, líder indiscutido durante décadas, en cambio, ha ido perdiendo una parte significativa de su hegemonía en el orden internacional. Lo que valida una sensación térmica de urgencia (Javier Navarro, 2017). 
Actualmente, el miedo está ganándole la pulseada a la población europea frente a los hechos de terrorismo. Los atentados se suceden, y cada vez más en países donde hasta hace algunas décadas era impensado, como en Francia, país que a su vez concentra un gran grupo de refugiados musulmanes, característica que alimenta la división étnica interna y el miedo de represalias de tipo religiosas. A partir de eso, todo se sucede como efecto dominó, el miedo hace que las poblaciones no estén abiertas a recibir refugiados, que quieran fronteras más fuertes y cerradas, y que exijan que primero se garanticen sus derechos, frente a los de los refugiados. Esto hace que los diferentes partidos políticos de extrema derecha estén ganando cada vez más terreno en Europa, y se aliente el cierre de fronteras. En paralelo, no se puede obviar la situación bélica en Siria, con la toma de tierras por parte del ISIS y la consecuente migración de sirios escapando del país.

Indefectiblemente, esta sensación de inseguridad, y realidad, se traslada a Estados Unidos, donde el escenario se muestra aún más complejo. El país norteamericano hace décadas convive con el terrorismo y tiene un continuo flujo de inmigrantes de todo el mundo que ingresa al país - de manera legal e ilegal- en busca de trabajo y un futuro mejor. Por su parte, la población estadounidense valida la sensación de que el país perdió sus aires de grandeza, y comienza a observar que la facilidad con la que antes se accedía a los empleos se perdió y que alcanzar famoso sueño americano que siempre les prometieron, es cada vez más difícil. Es un hecho que los inmigrantes son cada vez más, que las desigualdades se profundizan, y que la crisis financiera de 2008 no hizo más que acentuar la situación, teniendo como consecuencia una profunda crisis de liquidez interna, y derramándose luego las consecuencias en el plano económico internacional.

Comienzan a tener preponderancia en este nuevo escenario geopolítico figuras como la de Donald Trump y su discurso político totalmente acomodaticio, ventajero y oportuno, en un contexto en el que sus rivales no supieron aprovechar. Trump tocó fibras y apeló a la emoción de la población, culpando a los inmigrantes de todo mal, prometiendo muros y asegurando que América -en clara referencia únicamente a Estados Unidos- sería grande de nuevo. -Slogan acuñado por Reagan en 1980 y utilizado por Trump en la campaña presidencial 2016-.

El panorama sudamericano, en este fin de siglo, no podría ser peor. Se están terminando los populismos contemporáneos y aquellos gobiernos que no comulgaban con la propuesta del bloque dominante, priorizaban el crecimiento y la distribución de ingresos, sin preocupaciones suficientes por los riesgos consecuentes como inflación, déficit financiero, devaluaciones, etc., y tenían leyes benignas para la inmigración -con los xenófobos y racistas de la derecha extrema- están mutando hacia una creencia mucho más antagónica y una situación de crisis profunda que da por supuesto el inicio de transformaciones políticas y económicas de fondo.

La afirmación sería pues, que el cambio que se espera ver si el mundo sigue este camino, será el del desarrollo de nuevas instituciones, sumado a una nueva situación migratoria regional y urbana por sobre la transfronteriza, y el surgimiento de nuevos centros financieros de índole local. A nivel corporativo, el cambio más importante podría llegar a darse con el aumento de las compañías regionales, y sobre todo, al aplastamiento económico de estas para con las multinacionales existentes. Se proyectan mejoras en el desarrollo humano, sobre todo en relación a las desigualdades existentes, que conduzcan a una mayor 
estabilidad y el desarrollo de economías locales más ricas y fuertes gracias a la continuidad de la tendencia de los consumidores de mercados emergentes. Esta tendencia alimenta el proteccionismo y la sustitución de importaciones, y en consecuencia, las políticas comerciales orientadas hacia el interior ganan cada vez más terreno, a medida que las economías buscan impulsar el empleo y la actividad económica dentro de las fronteras (Flores, 2017). Esto efectivamente pone en jaque el concepto de globalización, modernización y educación, como se conocía hasta ahora, para pasar a un mundo multipolar, siendo ese el escenario más realista. Y, en este sentido, vivir una vida de expectativas inflexibles es una receta al desastre (Asma, 2017).

\section{La concepción de un mundo multipolar}

En primera instancia cabe aclarar que aquí se entenderá a la globalización desde el aspecto económico y se la concebirá como "proceso por el cual dos o más estados deciden estrechar sus relaciones económicas, creando mecanismos para la integración gradual de sus economías"(Dabbah, 2015). Esto lo que busca es la supresión de muchas de las barreras arancelarias, para favorecer la libre circulación de capitales -financieros, comerciales y productivos- con el objetivo de alcanzar la libre movilidad de ese capital y la creación de un solo mercado mundial. Este tipo de integración ha cambiado hasta el momento el rumbo de la historia en diferentes ámbitos, ampliando el espacio económico entre países que tenían mercados separados, constituyendo un solo mercado de dimensiones mayores, e incluso disminuyendo conflictos internacionales a raíz de la dependencia recíproca que se generaba a partir del estímulo comercial (Villamizar, 2000).

Actualmente, estas relaciones de interdependencia que se perpetraron con la fantasía de que la globalización hacía accesible el mundo al mundo en general, están agrietándose. Durante décadas se enmascararon las desigualdades y asimetrías provocadas por la falta de integración económica real (Arroyo Madera et al., 2015). Hace tiempo se tiene la evidencia de que la globalización y homogeneización sólo corren paralelos en las fantasías utópicas o en el imaginario fantástico de aquellos que tienen menos que perder y mucho para ganar. Asimismo, como también se analizó párrafos más arriba, desde el punto de vista geográfico no existen los países centrales ni periféricos. El concepto es exclusivamente de naturaleza política, y hoy se está redibujando. Los politólogos actuales comienzan a esbozar sus definiciones de multipolaridad, y la proponen como alternativa de adaptación al cambio. La más utilizada es la que asegura que habrá un desarrollo económico político y social dividido por regiones, en detrimento de la falsa integración e interdependencia mundial provocada por la globalización (Flores, 2017).

En este contexto, la teoría de un mundo multipolar representa una dirección única que ya no se vale de calificaciones reduccionistas como progreso versus conservadurismo, o viejo versus nuevo. La visión globalista de muchos pretende analizar el fenómeno como un proceso lineal en el que del subdesarrollo se pasa al desarrollo, y eso se mide de manera cíclica. Aunque es poco probable que la globalización se detenga por completo, quienes tienen la visión de un mundo multipolar, sostienen que el concepto de irreversibilidad de la globalización no puede probarse del todo cierto. Es verdad que el mundo universal y 
globalizado al que muchos se han acostumbrado ha tomado otras formas; pero el retorno a cero o el viraje a un estado previo total, es poco probable, puesto que la conectividad y la inmediatez de la información y la internet hace rato han transformado el modo en el que la humanidad se interrelaciona, personal y económicamente.

En este caso, se cree que es posible dejar de lado el "dogmatismo de un proceso lineal o monótono", para pasar a la interpretación del paradigma multipolar como un "proyecto de organización de orden mundial bajo principios y elementos absolutamente nuevos", permitiéndose una "revisión importante de los axiomas ideológicos, filosóficos y sociológicos sobre los que descansa la modernidad" (Dugin, 2018).

La diferencia fundamental entre la visión globalista, y la multipolaridad es que mientras la primera defiende a ultranza intereses comerciales que no son otra cosa más que el enmascaramiento de acuerdos entre unas pocas partes interesadas en obtener un rédito inmediato, sin medir las consecuencias a escala mundial; la segunda detecta en la sociedad una tensión creativa y un esfuerzo por construir una sociedad más feliz, justa y armoniosa. Observan al futuro como diferente y desigual y hasta conservador dentro de la amplia paleta de opciones de sociedades que experimentan la influencia de distintas matrices de identificación. ¿La consecuencia? Una floreciente complejidad del mundo, donde múltiples actores individuales y colectivos se sumergen en un diálogo para transformar re-encontrar su identidad. Se plantean nuevos escenarios, y un nuevo paradigma basado en diseños éticos por sobre los estéticos. Y lo que es más importante, que esa ética emergente se muestra preocupada por el medio ambiente y el desarrollo local. El compromiso social demuestra ser hoy el $100 \%$ del proyecto, y estar a su vez compuesto por un $90 \%$ de empatía, compromiso y sensibilidad; y un 10\% de diseño -entendido este como la acción de proyectar objetos útiles- (Cambariere, 2017).

El dilema puntualmente entonces es, ¿cómo logran los diseñadores en -este caso- acomodarse en este nuevo escenario coyuntural? El colectivo se ve hoy obligado a desarrollar su costado más sensible y mostrarse cada vez más receptivos a determinados asuntos o problemas y proclives a ponerles solución.

En esta nueva era del diseño, el diseño artesanal resulta ser la estrella, y esa energía creativa (Berman, 1992) que en algún momento se expandió sin límites por doquier, hoy se dosifica. El mundo se encoge y lo que alguna vez se pensó como federativo, hoy se reconoce con signos de dominación y competencia más que cooperación (Santos, 1993).

\section{Replanteo artesanal}

Durante años los referentes de la disciplina incorporaron fórmulas que les eran ajenas y no sólo soslayaron voces propias, sino que, impusieron un paradigma insostenible y muy limitante. Lo bueno es que ese paradigma se está resquebrajando y se plantean nuevos escenarios para el diseño, donde este entra en contacto directo con los seres humanos y el desarrollo local es inevitable (Cambariere, 2017).

A diferencia de años anteriores, donde la transición que se vaticinaba era de un mundo globalizado hacia uno glocalizado con la intención de entender las maneras globales actuando localmente para producir nuevas culturas (Buey Fernández, 2017), la tendencia 
actual pretende el rescate de técnicas, materiales y un cuidado del medio ambiente que básicamente sirvan de ejemplo al mundo. Ya no se pretende llegar al mundo con diseños que gusten al mundo, sino que se pretende llegar al mundo con lo propio.

La incorporación de la historia a la mirada moderna es el factor clave de evolución. La humanidad entiende ahora que el binomio estrella tiene que ser el diseño de la mano de lo social para el desarrollo de nuevas y mejores economías.

En este contexto de cambios permanentes, controlar y reducir la incertidumbre del entorno se ha vuelto tarea casi imposible, pero, se trata de entender que esta nueva oportunidad exige profesionales con una mirada mucho más seria y responsable para con el contexto que los recibirá. Profesionales capaces de modificar positivamente el entorno en el que se mueven, y capaces de reconocer los continuos cambios, necesidades, expresiones, requerimientos y tendencias del contexto actual. Y capaces de analizar en forma crítica los requerimientos y valorarlos de manera integral, detectando las implicaciones estéticocomunicativas, técnico-productivas; así como éticas, económicas, políticas y ambientales de sus propuestas, para proyectar no nuevas culturas, sino, nuevos productos y con ellos, nuevos lenguajes comunicativos.

Las nuevas oportunidades de interacción conducen, de un modo u otro, al proceso clave de detección de oportunidades de diseño, y no necesariamente necesidades de diseño. La mirada está enfocada en el por qué se hacen las cosas más que en la cosa en sí misma; y los esfuerzos por dotar de significado nuevamente al término diseño, son innumerables.

El diseño fue, es y será trascendental para la vida de las personas y el desarrollo humano en general. El buen diseño puede salvar vidas. El diseño media casi todas las acciones cotidianas de una persona. Casi todas las acciones que se hacen en el día a día están intermediadas por una interfaz de diseño, sea esta concebida o no por un diseñador. Desde una cuchara, hasta un avión, pasando por instrumental médico, todo, todo, está mediado por el diseño. Sin embargo, lamentablemente a veces las personas, incluso los mismos diseñadores, ligan al diseño a su aspecto más reduccionista de moda u objeto práctico-funcional únicamente, y mal cargan de significado al término. Pero ¿qué es el diseño en realidad?

El diseño tiene que ver con el proyectar un mundo mejor y no existe de otra forma más que concibiéndolo en relación a las personas. La mirada estratégica hoy condena en cierta medida a la mirada del primer mundo como único referente, para volver a reconocer en cada uno de los agentes partícipes de este mundo en transición, la revalorización del mínimo recurso que es el máximo; de la creatividad, la imaginación, el reciclar lo reciclado la búsqueda de recursos constantes. Sentirse parte de la naturaleza y trascender lugares comunes que hoy tiene el diseño y concentrarse en objetos menos analizados, para recobrar la esencia de las definiciones y lo artesanal de las vinculaciones. Esta nueva era de transición aspira a ser un nuevo espacio propicio para el diálogo, derribando prejuicios y echando luz sobre la pluralidad de creaciones de los diferentes pueblos.

Lejos de un perfil nostálgico, lo interesante del sentimiento actual es mostrar cómo las diferentes culturas se puedan encontrar, contraponer y dialogar, para transpirar una contemporaneidad tal que reinvente las lecciones del pasado. De transparentar las decisiones, de que todos formen parte de un saber popular que debe ser visto como fuerza vital para el desarrollo en este nuevo esquema geopolítico y nuevos mercados de los que se hablaba anteriormente. 
"Ni la modernización exige abolir las tradiciones, ni el destino fatal de los grupos tradicionales es quedar fuera de la modernización", explicaba el argentino Néstor Canclini (2010) entrevistado en marco de la inauguración de la muestra brasilera Puras Misturas inaugurada el 11 de abril de 2010 y que bien sirve como muestra clara de esta transición de la que tanto se viene hablando.

Dicha muestra creía vital la creación de un espacio de legitimación de diferentes prácticas culturales y sobre todo, de legitimar a aquellos productores de cultura y significados plurales, por encima del mero mote de consumidores. El aspiracional de ese tipo de exhibiciones es, gracias a la inclusión de temas, perspectivas, lenguajes, visiones, público, culturas, etc., servir como espejo para que el conjunto de ciudadanos de la región, en este caso Brasil, se reconozcan y sean reconocidos, tendiendo puentes entre la periferia y el centro, revelando, canalizando e irradiando el poder transformador de la creación popular (Borges, 2010).

\section{Innovación genuina}

Los diseñadores interactúan con las fuerzas de la modernidad de tal modo que los nuevos diálogos entre diseñadores, artesanos, autores y pensadores de la materia, tienen como objetivo primero el desarrollo de las poblaciones que quedaron desplazadas. Los nuevos escenarios se plantean propicios para la innovación estratégica sin dejar de lado la ética ni lo social.

Lo que para muchos estalló en la Argentina en 2001, para diseñadores como Beatriz Galán, se comenzó a vislumbrar en los años '90 y terminó de verificarse en los últimos años en el ámbito del diseño nacional e internacional donde hoy hay que explorar nuevos escenarios y nuevas formas de actuación, y donde el diseñador está obligado a asumir nuevos roles lejos de la innovación comprendida como un efecto meramente imitativo de lo que se ve novedoso en países centrales. En la región se comprobó que existen otros móviles, sobre todos los éticos, que tienen que ver pura y exclusivamente con el interés en el arraigo territorial, validando el esquema multipolar (2006).

Son esas condiciones coyunturales y circunstancias dadas del contexto las que generan los elementos y plantean los escenarios para alcanzar la tan deseada innovación genuina y estratégica. Es necesario entender que la innovación genuina de la que hablan los expertos, sólo será posible si se comprende que las problemáticas que ingresan en los territorios son, en la mayoría de los casos, problemas construidos y poco tienen que ver con los problemas locales, por eso, equivocadamente se rechaza el problema, cuando se debiera rechazar el marco teórico (Galán, 2006).

Para Eduardo Naranjo (2006), el que legitima es aquél que viene a buscar en el otro lo que el otro no tiene. Aquellos que van en busca de nuevos recursos y saberes, para apropiarse de esos y evitar migraciones indeseadas. El enfoque actual, en este sentido, es la interacción y la transferencia en la acción. El diseño no es un nuevo objeto, es un catalizador, un mediador, cómo se define antes en este escrito, para el diseño de un mundo nuevo y mejor. En el marco de las jornadas Diseño para el Desarrollo Local organizadas en la UBA en el año 2006, el diseñador dio cuenta de su postura acerca de esta visión de legitimiza- 
ción y de una experiencia en particular: Laboratorios de Paz. Una iniciativa especialmente ideada para las zonas de conflicto, las zonas rojas, que pretende de la mano de la cultura -fortaleciendo la artesanía, la música y el teatro- ser otra vía para reducir el impacto de la violencia. Estas iniciativas, son otra muestra de fortalecimiento de los actores involucrados para ordenar recursos con criterios de eficacia social; lograr comunidades mejores posicionadas y profesionales competentes para accionar en escenarios complejos, quebrar estereotipos y, lo más importante, volcar su atención a la realidad local en pos de descubrir su riqueza sin imitación (Naranjo, 2006).

\section{Educar para no competir}

La educación afronta hoy un desafío muy grande. En el marco de World Economic Forum que se realiza todos los años, también conocido como el Foro de Davos, Jack Ma (2018) afirmaba que para el año 2030 las máquinas reemplazarán 800 millones de puestos de trabajo ocupados por humanos. Por esto, si no cambia la forma en la que se enseña y sobre todo, lo que se enseña, en 30 años la humanidad estará en problemas.

Por consiguiente, frente a este panorama desalentador en la teoría, pero altamente positivo en la práctica, ¿cómo se siembran las semillas de un mundo posible?

La respuesta está en la educación. Se suele decir que educando bien a un niño/a hoy, ya nadie tendrá que preocuparse por el calentamiento climático el día de mañana. Y si bien la cuestión no es tan directamente proporcional y lineal, el concepto se logra comprender de buena manera.

Los modos actuales se basan en la enseñanza de conocimiento, en el desarrollo de habilidades duras y responde a preceptos algo arcaicos. Esos modelos basados en el conocimiento no sirven hoy para enseñar a las generaciones futuras a competir con las máquinas, ellas ya son más inteligentes.

Aquello a lo que te resistes, persiste, decía Carl Jung (s/f) en varios de sus escritos. Y no podría definir de mejor manera una actitud altamente enraizada en la mayoría de los seres humanos: la de aferrarse a aquello que es conocido y a las ideas e imágenes preconcebidas, sin lugar a la validación -o no- posterior, ni siquiera a la posibilidad de reflexión en el tiempo. Los docentes actuales tienen que dejar de enseñar mero conocimiento, traspasar información y datos, para enseñar algo único. Esto único es lo que hará que entonces sean las máquinas las que nunca alcancen la vara de la humanidad. Sólo cambiando la educación, los niños del futuro podrán dejar de competir con las máquinas del presente.

Comprender la naturaleza cambiante del nuevo esquema geopolítico y los nuevos modos de trabajo, va a requerir una mejor comprensión de la tecnología. Es esencial entender el lugar que ocupan determinadas tecnologías, para ser usuarios poderosos de aquellas.

Porque en todo caso, si la máquina realiza determinadas tareas de una mejor manera, ¿cuál sería el sentido de ir a la carrera por sobrepasarla? El objetivo del nuevo esquema multipolar, no es ni más ni menos que, cambiar el diálogo social. Desarrollar el mundo a partir del empoderamiento de las economías locales. Replantear lo artesanal, darle voz a los desplazados. Y no hacer esto en un tópico en particular, sino, derramar estos esfuerzos en todos los órdenes de la vida. 
Eso único que debiera enseñarse son habilidades blandas, inteligencia emocional: valores, creencias, pensamiento independiente, trabajo en equipo, características de liderazgo, saber cuidar, conocer cómo convivir con la naturaleza, tener la capacidad de compartir, etc. La práctica de deportes, la música, la plástica, y todas las artes que garanticen la enseñanza de algo diferente, y la construcción de personalidades diferentes una de la otra, contribuirán a la formación de profesionales con un desarrollo pleno, para convertirse en personas autónomas, creativas y completas, que puedan construir conocimiento, comunicarse, participar e identificar su impacto para que sean autónomos y contribuyan al entendimiento del mundo en general.

El mundo afronta el final de un sistema altamente engañoso, un período de privatizaciones y explotación. El mercado está cambiando, los trabajos están cambiando, la sociedad está cambiando, la tecnología cambia de manera tan veloz, que nadie garantiza que lo que se aprenda hoy sea útil mañana. Uno debe estar armado, preparado para afrontar eso y por tanto, generaciones actuales debieran aprender habilidades que les permitan modificar esas habilidades en un futuro. El estudio de las ciencias, las matemáticas, la reflexión histórica, la computación, el big data, son importantes, pero el pensamiento crítico, el pensamiento analítico, la comunicación y el trabajo en equipo son fundamentales para conseguir empleo, independientemente del área de desarrollo final.

Como educadores, es necesario asegurarse que los futuros egresados sean ciudadanos capaces de enfrentar los desafíos de ese mundo transformador, como aprendices constantes y no paralizarse ante ellos. No tener miedo del poder engañoso, deshonesto y brutal del poder, es la verdadera libertad.

Es obligación de cada uno reconocer que recobrar el trabajo con las manos y la mente, de manera interconectada, es la evolución más inteligente de la humanidad. Crear comunidades de trabajo y consumo, versus productores y consumidores atomizados, es la verdadera libertad.

Mirar hacia adentro para despertar, en vez de soñar mirando hacia fuera, es el único modo que existe de desarrollo en este mundo en guerra, sumido en una puja constante de intereses, fragmentado y hambriento de significado y sentido.

\section{Listado de referencias bibliográficas}

Arroyo Madera, M.A., et al. (2015). La globalización y la integración económica ¿el fin a las guerras mundiales? Recuperado el 15/12/17. Disponible en: http://revistas.unisucre.edu. co/index.php/rpg/article/view/156/198.

Asma, S. T. (2017). We could all do with learning how to improvise a little better. Recuperado el 10/12/17. Disponible en: https://aeon.co/ideas/we-could-all-do-with-learning-howto-improvise-a-little-better.

Berman, M. (1992). Todo lo que es sólido se deshace en el aire. San Pablo: Compañía de las Letras. Borges, A. (2010), en Cambariere, L. (2010). El museo de la inclusión. Sumplemento m2, Página 12, 17 de abril.

Buey Fernández, M. (2017). Involúcrame y entenderé. El gran reto de no estandarizar, sino, subir el estándard. Buenos Aires: Universidad de Palermo. 
Cambariere, L. (2017). El alma de los objetos. Buenos Aires: Paidós.

Dabbah, S. L. (2003). Globalización económica. Méjico: Ediciones Fiscales ISEF en La globalización y la integración económica, 3 de Febrero de 2015. Recuperado el: 10/11/2017. Disponible en: http://revistas.unisucre.edu.co/index.php/rpg/article/view/156/198

Dugin, A. (2018). Main factors in the development of global processes: results and prognoses. Recuperado el: 18/1/2018. Disponible en: https://www.geopolitica.ru/en/article/ globalisation-and-its-enemies.

Evans, M. (2007). Predicciones para el diseño a futuro. Revista iF. Buenos Aires: Centro Metropolitano de Diseño. Número 3 Abril. Págs: 75-80.

Flores, M. (2017). Multipolaridad. El nuevo fenómeno mundial que reemplazaría a la globalización. Recuperado el 12/11/17. Disponible en: http://www.emol.com/noticias/ Economia/2017/01/19/840649/Multipolaridad-El-nuevo-fenomeno-mundial-quereemplazaria-a-la-globalizacion.html.

Galán, B. (2006), en Cambariere L. (2006). Para dar diseño. Sumplemento m2, Página 12, 17 de abril.

Harari, Y.N. (2014). De animales a dioses. Breve historia de la humanidad. Buenos Aires, Argentina. Editorial: Penguin Random House.

Harari, Y.N. (2016). Homo Deus. Breve historia del mañana. Buenos Aires, Argentina. Editorial: Penguin Random House.

Jung, C. G. (1964). Acercamiento al Inconcsciente. En El hombre y sus símbolos. Barcelona: Paidós ISBN: 84-493-0161-0.

Ma, J. (2018). World Economic Forum. (2018) Recuperado el 25/1/18. Disponible en: https:// www.weforum.org/events/world-economic-forum-annual-meeting-2018

Naranjo, E. (2006), en Cambariere L. (2006). Para dar diseño. Sumplemento m2, Página 12,17 de abril.

Navarro, J. (2017). Mundo Multipolary Bipolar. Recuperado el: 11/12/2017 de: https://www. definicionabc.com/politica/mundo-multipolar-bipolar.php.

Néstor Canclini (2010), en Cambariere, L. (2010). El museo de la inclusión. Sumplemento m2, Página 12, 17 de abril.

Santos, M. (1993). Aceleración Contemporánea: tiempo mundo y espacio mundo. En: Fines de Siglo y Globalización. San Pablo, Hucitec-ANPUR, 1993. Recuperado el 20/12/17. Disponible en: http://www.charlespennaforte.pro.br/multipolaridad_y_globalizacion.htm.

\begin{abstract}
In a changing and globalized world, which shouts for innovation, identity and meaning, it seems that those who expect the world to adjust to its calculations and predictions are destined to be frustrated. Historically, changes have been scary because the unknown scares. However, life today is intrinsically changing, moving, disappointing and surprisingly positive. In this sense, living a life of inflexible expectations is a recipe for disaster. (Asthma, 2017) In short, the rules and structures are not divine creations. What is to be done when recognized and familiar structures fall?
\end{abstract}


The world is immersed in times of drastic changes. The powers are weaken, the masses are scattered and the earth cries. But humanity is no longer afraid of change, it seeks change; the rules follower is frustrated and the improviser adapts.

Keywords: sociology - globalization - culture - debate - design - innovation - present.

Resumo: Num mundo em mudança e globalizado, que clama por inovação, identidade e significado, parece que aqueles que esperam que o mundo se ajuste aos seus cálculos e as previsões estão fadadas a serem frustradas. Historicamente, as mudanças medo porque o desconhecido assusta. No entanto, a vida hoje é intrinsecamente mostrada, comovente, decepcionante e surpreendentemente positivo. Neste sentido, viver uma vida de expectativas inflexíveis é uma receita para o desastre (Asma, 2017). Em suma, as regras e estruturas não são criações divinas, o que você faz quando as estruturas caem onde você viveu uma vida inteira? O mundo está hoje imerso em tempos de mudanças drásticas. Os poderes são enfraquecer, as massas se dispersam e a terra chora. Mas a humanidade não tem mais medo de mudar, procure a mudança; o seguidor de regras é frustrado e o improvisador se adapta.

Palavras chave: Sociologia - globalização - cultural - debate - design - inovação - notícias.

[Las traducciones de los abstracts fueron supervisadas por el autor de cada artículo] 
Fecha de recepción: abril 2019

Fecha de aceptación: octubre 2019

Versión final: marzo 2020
Fases y redes en la metodología
del Design Thinking

María del Mar Ketlun *

Resumen: En nuestro mundo de formas y dentro de la profesión del diseño existe un universo que nos rodea, que rota constantemente, una especie de mapa de constelaciones creado por diversos puntos que parecen ser todos centrales. Pensándolo desde figuras geométricas, notamos que tienen significado en sí mismas, y encontramos en ellas personas, objetos e ideas, triángulo que gira motivado por las ganas de crear significados. La disciplina del diseño actualmente intenta estar un paso al frente en cuanto a innovación se trata, y nos encontramos frente a la pregunta ¿cómo innovamos si nos dicen que todo está inventado? La respuesta podrá ser: lo inventado puede reinventarse. Para comprobar esto, se recorren distintas formas y áreas visuales, entrecruzando estas constelaciones con diversas técnicas para motivarnos a crear desde el Design Thinking, utilizando lo que percibimos y conocemos, logrando representar conceptos y estableciendo una correspondencia entre los componentes del problema según características estructurales, superficiales, objetivos del razonador y exigencias del entorno, con "personas" como factor clave en la metodología del Design Thinking, para lograr salir de la idea de uno mismo y generar empatía con la gente.

Palabras clave: Diseño - Design Thinking - formas - conceptos - analogías - humanizar - empatía.

[Resúmenes en inglés y portugués en las páginas 101-102]

${ }^{(*)}$ Diseñadora Gráfica (UBA) Facultad de Arquitectura, Diseño y Urbanismo. Docente en Medios Expresivos. Cátedra Feller (UBA) Facultad de Arquitectura, Diseño y Urbanismo. Miembro del equipo de Evaluación de Proyectos de Graduación de la Facultad de Diseño y Comunicación (UP). Docente en Introducción al Lenguaje Visual I en la Facultad de Diseño y Comunicación (UP). Profesora de la Universidad de Palermo en el Área de Diseño Visual en la Facultad de Diseño y Comunicación. Fundó y trabajó en Universal Brands y Oh! que Agencia como Directora Online y Directora de Arte. Trabajó en otros estudios y agencias como directora de arte y creativa. Dictó clases en otras instituciones.

\section{Introducción}

El diseño forma para de nuestro universo personal, donde todo lo que nos rodea parece ser armónico y perfecto, como las constelaciones que forman redes virtuales, armando fi- 
guras que no dejan de pertenecer al mundo de los objetos. Esos objetos que existen gracias a la luz y a la existencia del otro, del sujeto. Ese otro son las personas, pieza fundamental en nuestro mundo de creaciones, tratando de llevarlas a la superación de la innovación, que parece agotarse, aunque si la analizamos entre todos, no es así. Existe por sí misma en lo ya inventado. Es por esto que siempre nos hacemos la misma pregunta, a la hora de encarar un proyecto: ¿cómo innovamos si nos dicen que todo está inventado? Nuestra respuesta podría ser: Lo inventado puede reinventarse.

En este ensayo se presentan algunas miradas, visionando diversas áreas, entrecruzando las constelaciones y mostrando las metodologías del Design Thinking, desde nuestros significados percibidos y concebidos.

Para motivarnos a crear desde el Design Thinking podemos utilizar lo que conocemos, logrando representar conceptos y estableciendo una correspondencia entre los componentes del problema según características estructurales, superficiales, objetivos del razonador y exigencias del entorno, con personas como factor clave dentro de esta metodología. En esta teoría necesitamos lograr empatía y sinergia con la gente, para luego salir de la idea de uno mismo y mirar hacia afuera.

Definamos entonces qué es el pensamiento del diseño. Es un concepto que se fue incorporando en los últimos años en diferentes empresas para la creación de productos y servicios pensando en satisfacer las necesidades de los usuarios, siendo éstos, una pieza fundamental en el proceso de creación. La innovación y la creatividad son pilares en relación a esta metodología. Pero cuando pensamos en avanzar sobre dichos términos, también posamos la mirada sobre otras disciplinas. Sabemos que hay modos en los cuales nos acercamos más a la gente. Contando historias, tal vez. ¿Y dónde contamos historias? En nuestros posteos, cuando escribimos para publicaciones, cuando diseñamos. En esos momentos estamos atravesados por nuestras propias historias, nuestras obras estás inmersas en nuestras historias y parte de ellas son contadas hasta en nuestras ilustraciones. También los que se dedican al cine. Como se explica Marie Anne Guerin (2004), las historias se hablan, se escriben, se ilustran, se pintan o se filman. Pero en sí, la historia existe y es transmitida si es relatada por un individuo. Las palabras, los cuerpos, las diversas voces, la fotografía, todas ellas articulan las historias de todos.

\section{Secuencia para el éxito}

Nuestro espectador será el primer eslabón en la cadena de nuestros relatos. Es por esto que nos acercamos a la gente con nuestras historias, para convertirlos protagonistas durante un tiempo y espacio determinados.

Volviendo al método, ¿quiénes aplican la metodología del Design Thinking? La pueden utilizar desde emprendedores, hasta grandes empresas y creadores de todo tipo.

A continuación, podemos ver una de las tantas versiones que tiene la aplicación de dicho pensamiento.

El primer paso está vinculado con la experiencia del usuario ya que nos encontramos en la etapa de la comprensión. Comenzamos investigando para conocer el tema, ya que sin este paso no se podría abordar el tema correctamente. Luego continuamos con la observación, 
para lograr registros de lo que acontece al proyecto. Una vez que recopilamos toda la información pasamos a la definición. La definición del problema es la parte más importante del proceso ya que desata los nudos y despeja las nubes, para ver con mayor claridad hacia adelante.

Pasamos hacia otra dimensión. La de la creación. En esta etapa generamos la idea y el prototipo. Una especie de brainstorming o lluvia de ideas para quedarnos con una de todas las ideas, la más fuerte a nivel conceptual. ¿Pero, qué es en sí un concepto? Un concepto es la formulación de una idea o una imagen de algo a través de palabras. Cuando en la mente se almacena una gran cantidad de información, el concepto nace de esa información y le otorgamos un sentido. Por consiguiente, se realiza la búsqueda de ese concepto dándole sentido a las ideas. Para la búsqueda de un concepto y la generación de un brainstorming o tormenta de ideas, hablamos sobre ideas y conceptos. Una idea es una representación mental que surge del razonamiento o de la imaginación de una persona. Está ligado al conocimiento, la creatividad y el intelecto. Las ideas dan lugar a los conceptos, y a partir de él se comienza a reflexionar, pero la idea puede suscitarse en ausencia de reflexión cuando se habla, por ejemplo, de la idea de otro. El concepto es una representación gráfica de la simbología representativa de las palabras, son construcciones o mejor dicho proyecciones mentales de todo lo que nos rodea, y lo percibimos con símbolos. Ambos surgen integrando nuevos conocimientos y nuevas experiencias, y son unidad de conocimiento, de significado, de sentido, de contenido mental.

Bien, veamos ahora qué es el brainstorming o tormenta de ideas. En 1919, el publicista Alex Osborn la utilizó para desarrollar la creatividad de un grupo de personas y de esta manera motivar al pensamiento colectivo por sobre el individual. Consiste en desarrollar la imaginación asociando una idea a otra, vinculando estas y generando nuevas conexiones entre ideas.

A partir de estas definiciones pensemos entonces en qué es el partido conceptual, o mejor dicho, qué no es. No es un tema, porque el mismo, forma parte de una generalidad, si lo pensáramos como tema, nos faltaría un recorte desde el cual abordar ese tema. No son descripciones, porque las descripciones están en el plano denotado. Se necesita ir hacia lo específico, y desde allí producir una pieza a partir, de una idea generadora. Un partido conceptual debe ser visualmente productivo, porque nos orienta sobre una dirección en la representación de cosas. Al final, representaremos en imágenes toda la potencia metafórica del concepto.

Luego de hacer estas aclaraciones entendemos que para realizar un prototipo debemos hacer una bajada a modo de pensamiento visual, y por último tendremos que diseñar y ejecutar. Esta es la etapa del testeo y la implementación final. En nuestra secuencia podemos generar varios prototipos que testearemos luego con nuestros clientes. Algo importante no mencionado en la etapa de implementación es la comunicación de la innovación, que forma parte de la llamada storytelling. Si aplicamos dicho concepto a las grandes marcas reales, deducimos que Apple no sólo vendió sus productos contando cuánta capacidad tenían o que tecnología llevaban por dentro. Jobs tenía la certeza de que lo que ofrecía eran historias. Algo que él sabía bien como relatar, esto queda demostrado incluso en sus discursos. Esa historia única que te hace diferente. El arte de contar una historia para el cambio social, por medio de palabras que pueden ser escritas o conceptuales, pero con la 
consigna de llegar al alma de forma positiva, creando significados personales de llegada muy humana en el receptor-espectador. En el centro del storytelling se encuentra el enamoramiento, entre consumidor y producto. Aquí es donde aparecen las conexiones entre personas y marcas, pero en definitiva, muy personales, vinculando de forma inteligente lo racional con lo instintivo. Está técnica ya existe desde hace un tiempo, no es nueva, pero sí se encuentra en constante búsqueda, ya que también se aplica y se adapta actualmente a las redes sociales y a la narrativa transmedia creando relaciones consolidadas con los usuarios de una marca y generando y actualizando constantemente el compromiso de la empresa con sus seguidores. La misma implica una participación directa de la comunidad, que incluye nuestra segmentación, el hilo argumental y la coherencia, siendo estos los desafíos que debemos atravesar aplicándolos de forma profesional. Para esto contamos con diversos canales de comunicación a los que debemos acudir para lograr el concepto de narrativa transmedia, generando varias piezas para los distintos medios, pero sobre la base de la misma historia. De esta manera, logramos que nuestro contenido se convierta en experiencia vivida. Asimismo una de las condiciones a tener en cuenta para generar buenas historias verdaderas es conocer a nuestra gente, nuestro público y nuestro entorno.

\section{La forma y la función}

El caso de estudio de Apple es esencial para entender la necesidad por parte de las empresas en crear nuevas formas para solucionar problemas, tarea principal del diseñador. La misma, forma parte de las compañías líderes y es altamente reconocida por sus productos y marca únicos en el mundo entero.

Pero, nos preguntamos realmente ¿cómo logra Apple ser diferente más allá del storytelling? ¿Cómo logra alcanzar la innovación? Este es uno de los casos donde se aplicó el pensamiento del diseño, con una estrategia y visión impulsadas por el consumidor. Conforma un proceso en base a soluciones desde lo innovador, considerando al consumidor en todas las etapas del desarrollo.

Para entender este pensamiento resulta adecuado citar a Tim Brown (2008), presidente y CEO de IDEO, en su artículo de "Design Thinking" para el Harvard Business Review, donde habla sobre el valor del Design Thinking y la innovación, y explica que:

Se trata de una disciplina que usa la sensibilidad y métodos de los diseñadores para hacer coincidir las necesidades de las personas con lo que es tecnológicamente factible y con lo que una estrategia viable de negocios puede convertir en valor para el cliente y en una oportunidad para el mercado (Brown, 2008, p. 4).

Si bien existen diferentes modelos de pensamiento de diseño, parece ser que todos comparten en la actualidad, el objetivo de lograr la innovación a través de tres factores principales: Generar el deseo del usuario a través de la resolución de problemas cotidianos mediante un proceso centrado en las personas. En este sentido, los diseñadores deben lograr una comprensión profunda del usuario mediante la empatía, parándonos en el lugar del consumidor. Para esto, encontramos herramientas como el mapa empático de personas. 
Por otro lado, hacer que el mercado sea viable, encontrando el segmento objetivo, aplicando estrategias de mercadotecnia para luego desarrollar marcas en base a ese segmento. ¿Pero, de qué forma se logra? Se puede utilizar el lienzo de modelo de negocio para analizar el proyecto completo y crear una estrategia comercial. Sumado a esto, las herramientas ya conocidas como el análisis FODA para comprender las fortalezas, debilidades, oportunidades y amenazas del producto en sí.

El último factor es la tecnología. La misma que nos genera constantemente temas de debate y está presente en muchas de las investigaciones abordadas por profesionales del área del diseño. Avanzando de forma rápida, nos proporciona elementos de última generación para lograr el pedido constante de innovar y crear piezas que realmente cumplan con las necesidades de la cultura que nos rodea. Un pedido que se gesta como un común denominador frente a la problemática del desarrollo profesional del diseñador que a su vez se basa en el advenimiento de nuevas tecnologías.

Asimismo se introduce el término novedad, como punto de partida para una nueva mirada en las comunicaciones desarrolladas, sobre los cambios en la interacción social, y el fenómeno de lo estético.

Por consiguiente aparece nuevamente el planteo, ¿las nuevas tecnologías, conllevan hacia nuevas estéticas? La idea de novedad y las nuevas tecnologías navegan hacia a la re significación de la imagen sin tratar de reproducir o copiar, sino de generar su propia existencia. Las visualidades que desarrollamos por medio de las tecnologías nuevas, pueden decodificarse como objetos tecnológicos del hacer, que, reflexionando sobre esta frase, puede verse su origen en el arte rupestre que requería también de un dispositivo, de una herramienta, de una especie de máquina. Las nuevas tecnologías que se fueron desarrollando y sucediendo a lo largo de la historia, inventaron una suerte de era de máquinas y herramientas bajo el discurso de novedad.

Philippe Dubois (2000), las llama máquinas de imágenes. Desde la fotografía y el cine, hasta la imagen informática, encontramos que su conformación está dada por la tecnología. Asimismo el video, que no puede desvincularse de los dispositivos tecnológicos porque estos forman parte de su ADN. En todo este pasaje de imágenes y tecnología, se va rechazando lo viejo para dejarle lugar a lo nuevo.

En este sentido resulta pertinente citar a Dubois:

¿En qué reposa ese discurso de la innovación? Esencialmente en una retórica y en una ideología. La retórica de lo nuevo (...) produce un doble efecto reiterado: un efecto de enganche (...) y un efecto de profecía (siempre se trata de enunciar una visión del porvenir: a partir de ese momento nada será exactamente como antes, todo habrá de cambiar con el advenimiento de un mundo diferente que no hay que perderse, etc. -que tiene, en última instancia una función potencial de tipo económico (Dubois, 2000, p. 3).

Las nuevas tecnologías, no necesariamente conllevan hacia nuevas estéticas, ya que avanzan y evolucionar en sentidos diferentes, aunque sí se reactualizan figuraciones anteriores. Vinculando lo dicho, la tecnología podrá apropiarse de parte del proceso de desarrollo, 
para lograr un mejor resultado, en la etapa de gestación del prototipo para la representación visual del producto al grupo.

Para situarnos en el tiempo y ubicarlo sobre el ejemplo, Steve Jobs logró aplicar el pensamiento de diseño en su regreso a Apple en 1997, centrándose en los deseos de las personas, en lugar de pensar solo en base a las necesidades del negocio. De esta forma proyectó un cambio radical y una vuelta al corazón y la esencia de la compañía.

Cuando hablamos de desarrollar la empatía, estamos logrando por ejemplo, que una persona como yo individuo, ame un producto, un objeto.

Algo de esto fue alcanzado por Apple. El diseño ensamblado con un desarrollo meticuloso de ingeniería, donde sabemos como diseñadores, que debemos ponderar tanto la forma como la función. Construir sobre la simpleza y la usabilidad. Teniendo en cuenta diferentes factores, podemos pensar que hay una idea de forma que nos sigue a lo largo de nuestra profesión. Algo que nos enseñaron sobre las bases de otras experiencias, el respeto por las formas y el ser humano, logrando con visión creadora, estar un paso delante de los competidores.

Sobre las palabras, e aquí lo importante de la palabra en otra área como la arquitectura por ejemplo. Cuando Sullivan decía que la forma sigue a la función, hablaba de una ley que se impuso frente a todo.

Además de transmitir sus ideas en sus seguidores, Sullivan logra transmitir una filosofía de sus diseños para edificios de diversos usos. Ahora bien, ¿ con que finalidad se trae a este escrito? ¿Adónde llegan sus teorías? Se establece un paralelismo con el tema ya que llega a sostener sus ideas y generar palabras para esas creencias. Ideas que hoy en día se siguen debatiendo. Sullivan quería construir edificios bellos pero bajo un concepto fuerte, entendiendo los cambios de paradigma como pocos, movimientos históricos dentro y fuera de la arquitectura, para plasmar la belleza en un diseño nuevo.

Por otro lado, la distinción entre el lenguaje y lo visual es inevitable, ya que el lenguaje ocupa una parte muy importante dentro del aprendizaje. Cuenta con una fusión entre el almacenamiento y la transmisión de conocimiento e información. Modo en el cual podemos discutir ideas, porque de esta forma podemos conceptualizar.

En palabras de Dondis (1995, p. 21): "Se considera el lenguaje como un medio de llegar a una forma de pensamiento superior a los modos visual y táctil".

Por ejemplo, está el caso puntual del producto iMac que es conocido por sus características de alta calidad. Esta visión se formó de una estrategia de desarrollo basadas en determinar lo que hoy es la excelencia en ejecución, pero lograr mejorar el proceso de ejecución debió eliminar gran cantidad de productos nuevos y centrarse en los productos de mayor potencial. También lanzó su sitio e-commerce trasladando su interés en la materialidad y el cómo de los productos, dentro de la cultura propia del consumidor. El cómo es fundamental en la etapa de realización, porque dialoga con el universo morfológico, pero en nuestro caso y como diseñadores gráficos, no es ajeno a la comunicación y al lenguaje visual. Según Jobs (2003), el diseño es la forma en que funciona. No es solo lo que parece y se siente. La experiencia se encuentra integrada en las etapas del diseño de interfaces con pruebas exitosas de usabilidad, y su estrategia está conformada por la simplificación de la forma y la función, como concepto general. 


\section{Sobre lo bello y lo útil}

Además de hacer foco en la función, se busca a su vez que la forma sea bella, sin eliminarse una con la otra. Aquí es donde la innovación juega un papel fundamental en el desarrollo del producto. Entonces, realicemos una reflexión sobre lo bello y el arte. Ya desde la época de Platón se hablaba de este término, se sostenía que si una obra no cumple con su función en cuanto a la usabilidad, y aunque tenga formas bellas, no puede ser considerada como obra de arte. La utilidad se convierte con ello en un determinante fundamental del arte. Para completar y pensando en lo bello, la perfección y el deseo por lograrla, significa que lo bello para Platón también se corresponde con el infinito y lo mágico.

Cuando la gente nos consulta a los diseñadores a qué nos dedicamos, hay personas que dicen, qué encuentran divertido el hecho de ver y hacer cosas lindas todo el tiempo. Afirmar esto sería una contradicción, ya que si bien existe una discusión sobre el diseño y el arte, encontramos en el caso del arte, que existen obras desproporcionadas, y en cuanto al diseño, afiches fuera de las leyes de la Gestalt. Es por esto que se trata de no mencionar la palabra lindo como tal, sino que se traslada el sentido.

Según Zatonyi (1992) lo bonito como equivalente del arte es una trampa del poder para imposibilitar, o por lo menos dificultar, con este medio también, el crecimiento del hombre. Con ello, por otro lado, el arte se convierte en una especie de lujo al que sólo puede acceder el que dispone de un importante excedente de tiempo y dinero, y así el conocimiento del arte (por otra parte falseado), se reduce a un selecto y pequeño círculo de élite. Con ello se aleja al arte de su posibilidad de generar conocimiento, responsabilidad, cosmovisión, constantemente renovados.

Se considera entonces que la estética y el conocimiento del arte, para lograr la construcción interna del sujeto, consigue asimismo participar en la formación de su propia percepción y su capacidad de reconocerse en la mejora de su mundo, para tomar conciencia de lo anterior y mirar hacia la actualidad. Lo pasado convertido en historia, y el presente elaborado desde lo profundo de nuestro ser, mirando hacia un futuro cercano para convertirlo en un devenir de lo nuevo.

Existe algo que es claro en la metodología expuesta en este escrito y es que a partir de conocer el mundo que nos rodea, más la comprensión del mismo podremos elaborar y tomar responsabilidad sobre lo que le ofrecemos al universo, y en nuestro caso a nuestro mundo real, rodeado de seres humanos que vivencian todo lo que decimos con palabras e imágenes, donde generamos significados que luego serán conceptualizados según el paradigma de cada ser, vinculado a su subjetividad. Lo bello y lo feo es uno de los objetivos de la estética. Definirlos aporta un orden a lo que conocemos para luego reacomodarlos, incorporando nuevas experiencias reelaboradas, generando nuevos conceptos con estructuras cognoscitivas. Debemos conocer para elaborar nuestros propios conceptos de las cosas. Y pensar en lo mágico como fuerza creativa.

Se entiende entonces que, la innovación, lejos de la copia, puede llevar al éxito de una empresa. Por eso, la historia de Apple, proporciona un ejemplo claro sobre éstas metodologías, para entender como se logra convertir el fracaso de un negocio, llevándolo de a poco, hacia el camino del liderazgo en un mercado competitivo. 
El pensamiento de diseño ayuda a innovar, colocando a los consumidores en el centro del proceso.

\section{Una mirada hacia otras propuestas}

Si bien existen varias formas para generar innovación, anteriormente escribimos una secuencia que puede funcionar y llevarnos al camino del éxito. En este escrito proponemos algunas otras y de las mismas, diversos pasos a seguir para llevarlo a la práctica.

Desde el lugar del cine, la mirada que nos ofrece relatar la evolución de diversas historias, estimula, por ejemplo, el deseo de llegar a la perfección por parte de los cineastas. Vamos hacia atrás en el tiempo y pensemos en Aristóteles que, en su "Poética" distingue al relato como "uno de los dos modos de la imitación poética", donde un "otro" el que representa hechos. Personas, actores, que dialogan con un público o ante un público. En el Arte de la ficción, Henry James (1978) explicita que la única razón de ser de la novela es la de llegar a reproducir la vida, estableciendo un paralelismo entre el artista, que genera pinturas, y el cineasta. Entonces, si el cine se nutre y encuentra su inspiración en la vida misma, en la cotidianidad, y en secuencias de hechos comunes que se repiten en muchos de nosotros como una especia de loop, y el pintor de cierta etapa histórica vincula lo objetivo con lo subjetivo en sus obras, asimismo sucederá en nuestros proyectos de diseño. La diferencia con el relato en el cine es que no se constituye en la realización de un objeto finito. En el cine seguimos las huellas que dejan los gestos mínimos, que conforman signos. Este es un relato que experimenta múltiples visiones, con lo cual, el espectador mira algo sin saber cual es su grado de interés hasta que algo lo atrape. Ambos convergen en que, si bien todos vemos lo mismo, no codificamos lo mismo. En este sentido, y en diversas áreas encontramos vinculaciones en cuanto a la creación y a la necesidad de superación.

Visualizando una forma más técnica de la cuestión, podemos preguntarnos, ¿Y si probamos otra secuencia? Otros pasos a seguir tales como comprender lo que otro ser humano puede sentir, definir, idear y accionar sobre la creación de un modelo, y por último, evaluar. Lo interesante en todo este proceso es lograr corrernos del lugar del pensamiento en el cual se considera que lo estético es el único lugar que ocupa el diseño. Debiendo considerarlo también, como parte de un proceso donde se forma una triangulación entre personas, estética y negocios.

Cuando practicamos la empatía, comprendemos en primera persona los problemas planteados. Lograr el accionar de forma rápida, es otro de los desafíos, para transformar las ideas en formas y las visiones en objetos reales, donde serán implementadas luego. Es importante tener en cuenta el factor de grupo o equipo de trabajo multidisciplinario para escuchar las diversas voces. Encontrar espacios flexibles para disparar toda nuestra creatividad, es otro factor relevante en todo este proceso. Y por último no detener nuestro paso decisivo y continuo, en este camino hacia la innovación.

Ya abordamos temáticas como la novedad, innovación y generación de ideas. Tenemos la constante inquietud de materializar estas ideas novedosas para lograr un alto grado de innovación en cosas que satisfacen a las personas. Pero, ¿que pasos marcamos en ese recorrido? Primero identificamos cuál es la necesidad, luego proyectamos una idea, y en un momento 
de inspiración diseñamos la solución al problema, sin olvidarnos de evaluar que funcione y estableciendo asimismo autocríticas. Listo, desarrollamos el objeto y lo testeamos.

Veamos otra forma. Podemos identificar una característica de un ser vivo como caso de estudio, y a partir del mismo logramos un desarrollo. ¿De qué tipo? Algo así como la imitación de la piel de tiburón para crear telas para trajes de baño, o los ojos de insectos que inspiran la creación sistemas de alerta para seguridad.

Existen otras miradas, que planteamos anteriormente, $y$ aunque nada aparece por arte de magia, sí existe una especie de magia en el arte que nos ayuda a sublimar nuestro ser. En nuestro proceso de sublimación también logramos objetivar. La otra mirada donde las soluciones están dadas es en la mimesis de la naturaleza misma y en realidad lo que necesitamos es readaptarlas. El rediseño, la readaptación, de algo existente se logró en distintas disciplinas, y forman parte de soluciones eficientes y sostenibles con el medio ambiente. La Biomimética estudia modelos naturales para llevarlos hacia otras soluciones de la existencia humana. Significa "imitar vida”. Sus áreas de estudio entre otras son robótica, nanotecnología, medicina y arquitectura.

La cotidianidad del ser encontró un lugar donde solucionar de forma sostenible mediante el aporte real de la naturaleza misma, y los diseñadores ya pueden consultar las bases de datos generadas para despejar sus dudas sobre cómo resuelve la naturaleza diversas problemáticas. Si la naturaleza pudo evolucionar para adaptarse a nuevas problemáticas, generando innovación en sus soluciones, también podemos trasladar este concepto a nuestros diseños. A la hora indagar en más ejemplos, encontramos el campo más desarrollado sobre la idea de inspirarse en la naturaleza. La biomimética robótica.

Nada más raro que un robot con forma de ser vivo. Reproduciendo ojos con el fin de explorar espacios diversos, con capacidad de adaptación al cambio de espacios, y agilidad para moverse en ciertos terrenos, las formas de insectos son las más generadas en este campo. Alas, patas, brazos, todo creado con sensores inteligentes para recrear movimientos como caminar, volar, saltar y escalar en superficies verticales, respondiendo al medio ambiente, basados en la biología de abejas, hormigas, etc.

Algunos de estos robots son nombrados como Scamp, Microtugs y Robobees.

En un estudio realizado sobre la desaparición de las abejas y lo que esto causaría a nivel mundial, se contempló la posibilidad de recurrir a la polinización artificial para asegurar la sostenibilidad de la producción de alimentos. Por último, investigando sobre los mamíferos, se lograron imitar la disposición sinérgica de los huesos, y utilizando diversos materiales, se aumentó la eficiencia energética en robots de este tipo.

Desde este punto de vista, se demuestra que podemos emular las soluciones que nos otorga la naturaleza de forma sostenible con el medio ambiente.

\section{Conclusiones}

Pensamos en la innovación como la generación de ideas novedosas que pueden ser materializadas en nuevos productos que satisfacen necesidades humanas.

Y siempre son las huellas que dejamos, las que otros retoman, aunque pensemos que estamos haciendo algo nunca visto. Para generar nuevas formas y lograr diferenciarse no 
es condición la creación de algo jamás visto sino de entender nuevas estructuras de pensamiento para re significar conceptos. El secreto radica en armar un modelo a seguir, un modelo para el negocio en cuestión, que se obtiene de probar e implementar nuestros prototipos surgidos de muchas ideas, con una única rectora, y como el design thinking busca llevar las cosas a la acción, también podemos recrear historias, contarlas desde el alma y desde distintos medios. Así, generamos una constelación de redes creadas por personas, donde la afinidad entre nuestro proyecto y la gente será inminente. De esta forma, estamos creando soluciones, y parece ser que alguien encontró las soluciones a nuestros problemas de vida y lo que podemos hacer es adaptarlas. Por eso, aquí se exponen ciertas marcas y proyectos, para explicar desde ese lugar, el "cómo" en cuestión. Tenemos la certeza de que estas soluciones que generaron diseñadores ó emprendedores como nosotros, son eficientes, porque ya fueron probadas en el mundo natural de las cosas. La naturaleza como fuente de inspiración fue utilizada durante siglos a lo largo de la historia y en diversos ámbitos. Mediante la biomimética se encontró un camino para posibles soluciones a la innovación de proyectos sostenibles con el medio ambiente. Existe un abanico de posibilidades que aún podemos explorar en las diversas disciplinas, dentro y fuera del diseño.

Por otro lado, vimos que establecer diálogos con los usuarios de los productos, termina por revelar que en la actualidad existe una relación emocional entre los consumidores y los productos. Esta especie de filosofía de pensamiento consolidada por Tim Brown, surge allá por el 2008, corriendo el foco desde la creación de productos estéticamente atractivos o desde una publicidad inteligente, hacia el universo de la innovación, pero centrados en el ser humano. Un método para satisfacer necesidades desde lo tecnológico y lo viable, aplicando la observación minuciosa de los cambios en las conductas actuales, combinados con la lluvia de ideas y la elaboración de prototipos de forma rápida. Hacer coexistir nuestras disciplinas en conjunción con relatos y narrativas realistas, entender los nuevos tiempos y espacios en su vertiginosa velocidad, para lograr la creación de un instante de encuentro, lazos, y una afinidad tal entre el producto y su futuro consumidor, que se logren acciones puntuales, mediante el hacer-hacer del diseño y la comunicación.

Hay puntos que nos unen y nos dejan dentro de una puesta en común, como lo hacen las constelaciones, nombradas a modo de paralelismo con el tema, que conforman figuras para ayudarnos a encontrar caminos en la noche. Una especie de revelación si nos vamos más allá de nuestra imaginación, las cuales podemos contemplar y pensar dibujos como ideas, sin que nadie no diga que eso que pensamos está mal. Los dibujos más antiguos de la historia. Una herramienta de inspiración, si seguimos navegando en sus segundos significados. En algún momento nos encontramos proponiendo caminos que se bifurcan y luego la magia del arte logra encontrarnos juntos, ya que ciertas culturas agrupaban estrellas en constelaciones, y aunque no siempre se correspondían entre sí, se pensaba en que algo las unía en la idea de un origen común a todas.

\section{Referencias Bibliográficas}

Design Thinking Case Study: Innovation at Apple. (2016). Disponible en: http://www.design orate.com/design-thinking-case-study-innovation-at-apple/ 
Dondis, D. A. (1995). La sintaxis de la imagen. Introducción al alfabeto visual. Barcelona: Gustavo Gili.

Dubois, P. (2000). Video, cine, Godard. Buenos Aires. Libros del Rojas. Selección: Video y teoría de las imágenes.

Guerin, M. A. (2004). El relato cinematográfico. Sin relato no hay cine. Barcelona: Paidós Ibérica.

Harvard Business Review: Design Thinking. (2008). Disponible en: http://5a5f89b8e10a 225a44acccbed124c38c4f7a3066210c073e7d55.r9.cf1.rackcdn.com/files/pdfs/IDEO_ HBR_DT_08.pdf

James, H. (1978) L'Art de la fiction. Éditions Klincksieck. Trad. Cast.: El arte de la ficción. (1992) Universidad de León.

¿Qué es el design thinking? (2016). Disponible en: http://www.bienpensado.com/que-esel-design-thinking/

Zátonyi, M. (1992). Una estética del arte y el diseño de imagen y sonido (2da ed.). Buenos Aires: CP67.

Abstract: In a world of forms and within the field of design there is a universe that surrounds us, that constantly rotates, a kind of constellation map created by diverse points that seem to be all central. Thinking from geometric figures, we notice that they have meaning in themselves, and we find in them people, objects and ideas, a triangle that revolves motivated by the desire to create meanings. The discipline of design is currently trying to be a step forward in terms of innovation, and we are faced with the question: how do we innovate if we are told that everything is invented? The answer may be: the invented can reinvent itself. To verify this, different forms and visual areas are crossed, crossing these constellations with different techniques to motivate us to create from Design Thinking, using what we perceive and know, managing to represent concepts and establishing a correspondence between the components of the problem according to structural characteristics, superficial, objectives of the reasoner and demands of the environment, with "people" as a key factor in the methodology of Design Thinking, to get out of the idea of oneself and generate empathy with people.

Keywords: Design - Design Thinking - forms - concepts - analogies - humanizing - empathy.

Resumo: Em nosso mundo de formas e dentro da profissão de design existe um universo que nos rodeia, que gira constantemente, uma espécie de mapa de constelação criado por vários pontos que parecem ser todos centrais. Pensando nas figuras geometricamente, percebemos que eles têm sentido em si mesmos, e neles encontramos pessoas, objetos e idéias, um triângulo que gira motivado pelo desejo de criar significados. A disciplina de design está atualmente tentando ser um passo à frente em termos de inovaçãoé, e nos deparamos com a questão, como inovar se eles nos dizem que tudo é inventado? A resposta pode ser: o inventado pode se reinventar. Para verificar isso, diferentes formas e áreas visuais são cruzadas, cruzando essas constelações com diversas técnicas para nos motivar 
a criar a partir do Design Thinking, usando o que percebemos e conhecemos, conseguindo representar conceitos e estabelecendo uma correspondência entre os componentes do problema de acordo com características estruturais, superficiais, objetivos das demandas raciocinadoras e ambientais, tendo as "pessoas" como um fator chave a metodologia de Design Thinking, para sair da ideia de si mesmo e gerar empatia com as pessoas.

Palavras-chave: Design - Design Thinking - formas - conceitos - analogias - humanizar - empatia.

[Las traducciones de los abstracts fueron supervisadas por el autor de cada artículo] 
Fecha de recepción: abril 2019

Fecha de aceptación: octubre 2019

Versión final: marzo 2020

\section{La evolución de los modelos de enseñar-aprender diseño en el nuevo escenario generacional}

Carmen Inés Galbusera Testa *

\begin{abstract}
Resumen: El enseñar-aprender diseño plantea desafíos en el contexto del paradigma global actual. Las generaciones de Baby-Boomers (1945-60) y X (1961-79), formadas en tiempos de guerra fría, son los organizadores didácticos de las generaciones NET o de nativos digitales: Millenials (1980-1993), Z (1994-2009) y Touch (2010-hoy). Los cambios cuantitativos y cualitativos se producen a velocidad acelerada en las dimensiones económicas, políticas, sociales, ambientales, tecnológicas y simbólicas desde fines del S.XX e inicios del XXI. Nuevas modalidades de enseñanza/aprendizaje producto de cambios generacionales, invitan a la reflexión crítica.
\end{abstract}

Palabras clave: enseñanza - aprendizaje - diseño - cambios - modelos - generaciones - reflexión crítica - contexto.

[Resúmenes en inglés y portugués en la página 114]

${ }^{(*)}$ Arquitecta Universidad de Belgrano 1980. Docente CBC-FADU-UBA 1985/actualidad. Docente Facultad Diseño y Comunicación Universidad de Palermo 2003/actualidad. Especialista en Docencia Universitaria FADU-UBA 2017. Especialista en Gestión Ambiental Metropolitana GAM-FADU-UBA 2015. Maestranda GAM-FADU-UBA. Investigadora PUC-FADU-UBA 2016/actualidad.

\title{
Introducción
}

¿Cuáles serían los principales cambios manifiestos en la enseñanza/aprendizaje del diseño en la educación superior? ¿Es posible identificar los modelos de aprendizaje que tienden a configurarse? ¿Qué impactos se perciben en los aprendizajes frente a la irrupción de las más recientes generaciones? ¿Cuáles son las generaciones que coexisten actualmente y cómo se facilitan las relaciones entre ellas? ¿Qué retos significativos presenta la Generación Net para la didáctica del SXXI? ¿Existen diferencias entre los propios estudiantes? Son muchos los interrogantes que estimulan la reflexión y el análisis. Los conceptos de enseñanza y aprendizaje del diseño, a la vez que el rol docente, deben ser redefinidos ante los nuevos escenarios del paradigma global actual.

La actividad de diseñar y su enseñanza, tiene una relación profunda y permanente con los procesos socio-culturales. Constituye un compromiso ético y de diálogo de los actores del 
diseño con la sociedad a la que pertenecen. De acuerdo a los avances obtenidos en algunos de los Encuentros de la Bienal Iberoamericana de Diseño (BID) realizados en Madrid en varias oportunidades, el objetivo principal de educar para y desde la innovación es ciertamente compatible con los valores más humanistas como la responsabilidad, el entusiasmo, la generosidad, la sinceridad, la empatía con el otro y con lo otro, el compromiso con el futuro y la pasión por diseñar "un mundo cada vez más abierto y justo". El diseñador es un actor clave e indispensable del cambio en las sociedades contemporáneas, independientemente del área o el contexto regional, nacional o internacional en que trabaja. El diseño implica comunidad y representa a la cultura como una construcción propia de una manera de habitar. El diseño actúa como gestor y generador de identidades, tanto en la escala local como en la global, en los espacios natural, social y económico. La actividad formativa del diseñador demanda del ejercicio usual, íntegro y valiente de la crítica tanto hacia su propio trabajo como hacia el medio social en el que se desenvuelve, como una garantía de ajuste y armonía constantes (5ºncuentro BID, 2013).

Los nuevos contenidos para la formación del diseñador deben ser transversales y transitivos: son procesos y habilidades orientados a capacitar al futuro profesional, superando la fragmentación del conocimiento transmitido en materias aisladas, relacionados con los contextos próximos, profundizando en estrategias y programas de acción para un autoaprendizaje continuo. Se propone formar a los futuros diseñadores con un espíritu emprendedor para que tengan iniciativa y sean capaces de generar sus propias propuestas liberando a los planes de estudio de rigideces impuestas por las instituciones de control, potenciando estrategias que favorezcan el aprendizaje significativo y se comporten como sistemas vivos, capaces de adaptarse y evolucionar de manera continua ( $5^{\circ}$ Encuentro BID, 2013).

Es tarea de todos los participantes en la enseñanza del diseño revalorizar su importancia en la sociedad, haciendo que éste sea entendido como agente de transformación y optimización permanente de la misma. Los centros formativos y de investigación en diseño pueden y deben actuar como laboratorio y espacio de generación del conocimiento, funcionando como agentes de cambio de los desafíos y problemas sociales que se viven. Una función inevitable de los centros debe ser también, acopiar, tramitar y propagar la memoria cultural de la disciplina del diseño. La comunidad del diseño y sus instituciones de formación se reconocen a sí mismas como comunidad de aprendizaje en la que todos, diseñadores, docentes, estudiantes, empresas, siguen aprendiendo constantemente y construyen su tarea a partir de la naturaleza, el ser humano y la historia (5º Encuentro BID, 2013).

\section{¿Cuáles serían los principales cambios manifiestos en la enseñanza/ aprendizaje del diseño?}

La formación en diseño necesita de instrumentos nuevos y actuales para implementar en las aulas y que la enseñanza del diseño necesita modelos de vínculo con las industrias, con la sociedad, con las ciudades y con la gente para hacer de la disciplina un segmento clave. En la actualidad, las instituciones afrontan el pasaje de los procesos formativos tradicionales hacia otros en los que las tecnologías tienen un peso específico importante; 
deberían asegurarse, a la vez, de que sus estudiantes alcancen las competencias necesarias para desenvolverse en medios laborales en los que el aprendizaje es incesante; deben competir, asimismo, en ámbitos internacionales y ser capaces de operar con la diversidad ( $6^{\circ}$ Encuentro BID, 2015).

La revolución digital y tecnológica coexisten con los vaivenes y la polarización social y cultural, a la vez que intervienen como factor de riqueza y acelerador de la dualidad, contribuyendo a desarrollar niveles nunca alcanzados de fortuna y prosperidad junto a patrones igualmente en aumento de precariedad y freno estructural. La tarea se enfrenta a nuevos retos, nuevos espacios y nuevos roles en donde se trabaja en equipos multidisciplinarios, interdisciplinarios y transversales y con sistemas abiertos y colaborativos. Esto implica una actualización de las maneras de relación y modelos de vinculación para dilucidar los marcos de referencia en los que se mueve el diseño, y una visión de las nuevas perspectivas que van del diseño perceptible al diseño intangible: diseño de servicios, diseño sostenible, diseño para la innovación social, diseño de información. El diseño visto como la articulación entre individuos y sus interacciones (7º Encuentro BID, 2017).

\section{¿Qué características tienen los modelos de aprendizaje que tienden a configurarse?}

Anna Escofet Roig, Iolanda Garcia Gonzalez y Begoña Gros Salvat desarrollan un profundo análisis y una clasificación basados en los nuevos y en los ya existentes modelos de aprendizaje observables actualmente en nuestras sociedades; los agrupan en tres categorías y tipos de aprendizaje: formal, no formal, informal.

En su investigación citan a Trinder, Guiller, Margaryan, Littlejohn y Nicol (2008, p. 13), quienes definen el aprendizaje formal como:

[...] el aprendizaje proporcionado por una institución educativa o de formación, estructurado (en términos de objetivos, temporalización y sistemas de apoyo al aprendizaje), implicando la presencia de un profesor o formador designado, $y$ dirigido a la obtención de una titulación, una certificación o acreditación.

Mientras que la segunda categoría, el aprendizaje informal, no supone ningún tipo de certificación. Es la consecuencia de las actividades sociales cotidianas relacionadas con la educación, el trabajo, la socialización con otros o la realización de actividades de ocio y hobbies. El aprendizaje informal puede ser estructurado o no estructurado, en términos de objetivos, tiempos y soporte del aprendizaje y puede ser intencional o no intencional (incidental) desde la perspectiva del aprendizaje (Escofet Roig, et al, 2011).

A su vez, apuntan las autoras, la Comisión Europea (European Commission, 2001) considera que una tercera categoría, el aprendizaje no formal, tiene lugar en un contexto institucional (e.g. un centro educativo o institución de formación), que es sistemático (en cuanto a la enunciación de propósitos de aprendizaje, duración del proceso y herramientas de enseñanza utilizadas), pero que no deriva en titulación o certificación oficiales reconocidas por el sistema educativo formal. Para el estudiante, el aprendizaje no formal es intencional 
y orientado a la obtención de unos objetivos determinados. Por el contrario, el aprendizaje informal tiene lugar en la cotidianeidad, en el trabajo, en la vida familiar o en el tiempo de ocio, pues no es estructurado ni organizado en los términos descriptos del formal y el no formal y corrientemente no implica ningún tipo de certificación.

Los autores Thomas y Seely Brown (2011), recurren a la expresión nuevas culturas de aprendizaje para mencionar aquellas formas que encarnan un concepto de raíz distinto de la creación y la distribución de conocimiento, y que confrontan claramente a la tradicional (Escofet Roig, et al, 2011).

\section{¿Qué impactos se perciben en los aprendizajes frente a la irrupción de las más recientes generaciones?}

En esta clasificación y descripción que proponen las autoras catalanas, se amplía que el aprendizaje informal aparenta constituir un subproducto o derivado de aprendizaje, que acontece espontáneamente y que, en general, no se considera claramente el objetivo o la consecuencia de ninguna maniobra. Además, la expresión comprende el conjunto de actividades de aprendizaje a desarrollar al margen de las tipologías establecidas de educación, con el objetivo intencionado de aprender, pero facilitadas en entornos informales. Este tipo de procesos -contrariamente a los formales y no formales- están organizados sólo por parte del propio sujeto que aprende. Los límites y relaciones entre ambos conceptos no son muy visiblemente abarcados y distinguibles. En la sociedad actual, las fronteras del aprendizaje formal e informal se desenfocan y problematizan. Este proceso se ha visto aumentado y evidenciado con el advenimiento de las tecnologías sociales (Escofet Roig et al, 2011).

Si bien Internet está presente e interviene en la vida diaria, hay que agregar el impacto social de la llamada web 2.0, expresión creada ad hoc para designar una nueva manera de concebir y usar la red, de intercambio social, que agrega un abanico de tecnologías a los usuarios de Internet y se actualiza continuamente: blogs, fórums, redes sociales, wikis, marcadores sociales y otras herramientas a través de las cuales compartir e intercambiar contenidos, crearlos en conjunto, rotularlos, etiquetarlos, exponerlos, re mezclarlos y re mixarlos, evaluarlos, etc. (Escofet Roig et al, 2011).

\section{¿Cuáles son las generaciones que coexisten actualmente y cómo se facilitan las relaciones entre ellas?}

La premisa fundamental para lograr un principio de entendimiento y comunicación entre diferentes generaciones es intentar conocer las características, las posibles raíces y condicionamientos de las mismas, con sus particularidades, considerando sus aspectos extraordinarios y sus limitaciones.

Varios autores utilizan la noción de generación como el conjunto de personas que comparten características distintivas según uno o varios criterios y que producen "comportamientos similares” en los miembros del grupo. En línea con esto según Ramón F. Ferrei- 
ro, el concepto de "generación" está vinculado a algún acontecimiento trascendente que produce transformaciones significativas en los integrantes de los grupos y de éste en su totalidad (Ferreiro R., 2000).

Un ejemplo clave de evento trascendente que afectó a los miembros de una generación, es de la Segunda Guerra Mundial, finalizada en 1945, que provocó en Estados Unidos de Norteamérica (EEUU) una explosión demográfica y cambios económicos, políticos y sociales que afectaron a los niños nacidos en el periodo posguerra. En coincidencia, el surgimiento de la televisión, por entonces la tecnología más poderosa en la historia, los marcaba a este grupo etario como generación y la sociedad cambiaba con la influencia de la misma. La ciencia de ese entonces le atribuyó el nombre de Generación Baby Boomer a todos aquellos que nacían, se educaban y desarrollaban en ese período (entre los años 1946 y 1964), ya que de manera evidente revelaban una forma de comportarse que lo definían como generación (Ferreiro R., 2000).

La publicación y éxito de una novela de Douglas Coupland, escritor canadiense que creó el término $X$ para describir a un grupo de personas nacidas y formadas desde mediados de la década de los sesenta del siglo XX en un contexto social y económico distinto al de sus padres y con perspectivas de vida también diferentes, ayudó a configurar el segundo ejemplo destacable: la Generación X. La abundancia económica de los años sesenta, los movimientos sociales de los países del Tercer Mundo, la guerra de Vietnam, entre otros sucesos, favorecen el surgimiento en EEUU y Canadá, según los investigadores de teoría de grupos, de una generación claramente reconocible: la Generación X (Ferreiro R., 2000). Las décadas de los ochenta y los noventa del siglo XX fueron escenario de la irrupción de las TIC, citadas anteriormente, cuestión que provocó cambios radicales y acelerados y llegó a plantear, más que una época de cambios, un cambio de época socio-cultural. En este contexto económico, social y cultural nace y se desarrolla una tercera generación intercedida por la evolución de las TIC y de la relación entre ambas: la telemática, concepto que refiere a la combinación de la informática y de la tecnología de la comunicación para el envío y la recepción de datos, responsable mayormente de un cambio de valoración de la realidad entre los miembros de este grupo de personas en pleno desarrollo, denominada como Generación Net, o N, o Net Gen, ya que de todas las TIC, computadora e internet constituyen sus insignias (Ferreiro R., 2000).

Nicolás Negroponte comenta en su libro "Ser Digital" que, como el acero en el siglo XIX y la electricidad en el XX, la revolución digital regulará la política, a economía y la sociedad del siglo XXI; se alterará la forma de aprender, de trabajar, de divertirse... toda la modalidad de vida. Lo anterior se alinea y refuerza con tendencias como la de la globalización o mundialización, como se sugiere decir en español, dado un aumento importante del comercio internacional y el intercambio cultural, la creciente comunicación e interdependencia entre los diferentes países del mundo (Ferreiro R., 2000).

El salto cualitativo se produce en la Net Gen al pasar de simples espectadores a usuarios con grandes posibilidades de participar, jugar, entretenerse, buscar, hacer, resolver, establecer relaciones, llevar a cabo proyectos conjuntos a pesar de la distancia y el tiempo. Don Tapscott alude desde inicios de la década de los noventa a esta nueva generación e identifica con la letra N, por el anglicismo "Net" (red), en referencia a la presencia e influencia de las redes beneficiadas por el uso de la computadora e internet. La Net Gen, que incluye 
a la Generación Y o Millenials (1980-1993) y a la Generación Z (1994-2009), considera unidireccional a la televisión, ya que no permite intervenir en las grillas de programación y contenidos (Ferreiro R., 2000).

Las TIC son la punta de iceberg de un fenómeno que influye y constituye conjuntamente con otras causas el contexto socio-cultural en que se desenvuelven los miembros de esta generación. Se tiende a considerar a la actual generación como un grupo muy heterogéneo de niños, adolescentes y jóvenes, en contacto directo y casi permanente con las TIC, lo que provoca una influencia muy trascendente en su vida (Ferreiro R., 2000).

Esta generación se muestra abierta al cambio, a consumir nuevas y flamantes tecnologías, y también a nuevas conductas y relaciones sociales, a modos de apreciar la vida desde otro ángulo, con o sin nuevos prejuicios morales. Los Nets ostentan una pasmosa capacidad de adaptación a toda actividad que involucra el empleo de las TIC en general y en particular de computadora e internet. Los miembros de esta generación son eminentemente activos, visuales, propensos al intercambio y emprendedores mediante el empleo de las TIC, dada la naturaleza integrativa, visual, auditiva y kinestésica de las TIC en general, y de la computadora e internet en particular y de sus múltiples aplicaciones (Ferreiro R., 2000). La revolución tecnológica en las sociedades estimula también cambios en las maneras en que los jóvenes practican las formas de consumo y producción cultural, las maneras de relacionarse, de comunicarse, de informarse y de aprender, así como muestran diversos estudios y análisis de tipo sociológico, antropológico, comunicacional y educativo (Turkle, 1995; Postman, 1991; Lankshear y Knobel, 2008). Las expresiones tecnológicas primordiales a que se hace referencia actualmente, son aquellas relacionadas con la telefonía móvil (chats en whatsapp, grupos de conversación, sms), los videojuegos (tanto los que se juegan off-line como on-line) y todas aquellas intervenidas por Internet, tanto en su versión web 1.0 (correo electrónico, chat, foros electrónicos, buscadores de información, webs temáticas) como en la versión web 2.0 (blogs, fotologs, wikis, mensajería instantánea con video y audio, podcast, redes sociales) (Escofet Roig et al, 2011).

La generación Net puede pasar horas en las computadoras sin notar del paso del tiempo y, en consecuencia, olvidarse de tareas a cumplir y compromisos contraídos. Esto puede alterar su horario de vida, afectando las horas de sueño, imprescindible para el recupero de la capacidad funcional del sistema neuro-físico, provocando estrés, ansiedad, depresión, fobias, o bien cuadros psicológicos agudos que afectan su salud física. En contraste con las virtudes antes detalladas, los Net Gen son ambivalentes, y a la vez que quieren ser tomados en cuenta para la resolución de problemas y toma de decisiones, demuestran apego a un mundo de fantasía creado por los medios de comunicación masivos, el cine e Internet. Es evidente que, por ejemplo, son biológicamente muy maduros y psicológicamente dependientes de las personas que les rodean. Exhiben a veces un conjunto de actitudes infantiles, desde caprichos hasta el rechazo a la responsabilidad, pese a su edad y nivel académico (Ferreiro R., 2000).

Mientras que la generación Baby Boomer tenía un sólo canal de televisión, tal vez una o dos marcas de gaseosas y un estreno cinematográfico semanal, por dar un ejemplo, la Net Gen accede a un sinfín de opciones y elecciones al alcance de la mano. En comparación con los riesgos que confrontaba la generación $\mathrm{X}$, que le precedió en el tiempo y relacionados con el consumo de tabaco, alcohol y drogas, los Net Gen tienen que lidiar con el 
aumento y variedad de la pornografía, la pornografía cibernética, y el empleo abundante, impredecible, y mal intencionado de infinidad de portales electrónicos diseñados ex profeso para tentarlos con todo ello (Ferreiro R., 2000).

Por efecto de ello y de múltiples causas es posible que el desarrollo humano se haya acelerado. Esta velocidad en el desarrollo humano estaría causada por múltiples factores, algunos socioeconómicos, otros ambientales, un tercer grupo relacionado con causas alimentarias, además de los procesos migratorios y el intercambio genético entre los miembros de una pareja (Ferreiro R., 2000).

A partir de la segunda década del nuevo milenio asistimos al surgimiento de la Generación Touch. Esta corresponde a personas nacidas en los años 2010 a 2020; se caracteriza por interactuar con los medios digitales directamente con las manos: tocar lo virtual es la manera habitual en que los Touch interactúan con los dispositivos. Esta generación está en pleno desarrollo, los miembros mayores tienen entre 7 y 8 años, y representa uno de los mayores desafíos educativos de la historia (Kostyrka-Allchorne K, et al., 2017).

En oposición con la perspectiva positiva de los posibles efectos del uso intensivo y generalizado de las TIC, tanto en las actividades de la vida cotidiana como en el aprendizaje, algunos autores se han referido también a los inconvenientes y contingencias de un papel dominante de las tecnologías como intermediarias de las prácticas socioeducativas entre los más jóvenes. Monereo (2004) delinea este lado oscuro de lo que él llama la construcción virtual de la mente: relativismo y confusión cognitiva, habilidades interpersonales deficitarias, mengua del compromiso social, infoxicación o intoxicación con información, tecno autismo o aislamiento social promovido por el abuso de la tecnología, son sólo algunos de los posibles problemas aludidos (Ferreiro R., 2000).

\section{¿Qué retos significativos presenta la Generación Net para la didáctica del SXXI?}

Desde una perspectiva educativa, llama la atención de los analistas de esta generación la inmediatez de sus acciones y toma de decisiones. Los miembros de la Net Gen se caracterizan por procesos de atención con márgenes amplios. En forma simultánea a la tarea que realizan, escuchan música, mantienen y trabajan con varias ventanas en paralelo, atienden el teléfono, chatean por whatsapp, suben fotos a Instagram, responden a una pregunta que se les hace en ese momento, entre otras. O sea, ostentan una capacidad de atención diversificada y distinta de la de generaciones anteriores, caracterizadas por profundizar más que por abarcar contenidos variados. Lo descripto posee un peculiar alcance pedagógico: es casi imposible mantenerlos atentos en un aula de clase tradicional, con un docente sentado exponiendo un contenido que muchas veces ellos mismos pueden consultar directamente en internet, mientras que a su vez intercambian con otros, localizan otras fuentes, pueden elaborar mapas o visualizaciones, es decir, y acá radica la clave del cambio generacional: participan de manera activa en la construcción del conocimiento (Ferreiro R., 2000).

El conocimiento declarativo (conceptos, leyes, modelos teóricos) y una serie de habilidades intelectuales se prestan para el trabajo “en línea”, mientras que el trabajo presencial en 
clase, se debiera aprovechar de forma didáctica para el desarrollo del contenido procesal (habilidades psico-motoras, sociales, actitudes y valores). El uso de computadora e internet favorece la actividad independiente (observación, exploración, búsqueda, comparación, ordenamiento, clasificación, toma de decisiones, procesamiento de la información y una serie de operaciones mentales: análisis y síntesis, abstracción y generalización) y también la actividad con otros en tiempo real (sincrónica) y en tiempo diferido (asincrónica), lo que facilita el trabajo en equipo cooperativo y las relaciones sociales con otros para aprender (Ferreiro R., 2000).

Esto lleva a reflexionar si las instituciones de educación superior y su plantel docente están preparados para responder a las expectativas de estos estudiantes y, a continuación, habría que preguntarse si en parte los problemas educativos relacionados con la deserción estudiantil tienen que ver con este desfasaje entre la naturaleza de los alumnos y los sistemas de formación actuales. Pareciera que, a partir de estos aportes, los estudiantes universitarios de hoy debieran ser altamente hábiles en el uso creativo de las tecnologías, en el procesamiento rápido y no lineal de la información, en la interpretación y el manejo del lenguaje audiovisual, en la interacción social en entornos virtuales, entre otros (Ferreiro R., 2000). El empleo de las nuevas tecnologías constituye un reto a vencer más en lo referido a lo pedagógico, que a lo tecnológico propiamente dicho. No se trata de incorporar lo nuevo en lo viejo, o seguir haciendo lo mismo con las tecnologías de punta. Introducir la tecnología por la tecnología misma en la educación sería ilógico, y tarde o temprano resultaría improcedente. No es posible educar a la generación Net sin el uso de las tecnologías que los unen y marcan como generación, en un nivel de necesidades de aprendizaje formal. Las investigaciones demuestran que la Net Gen no aprende de modo lineal, y evidencia los variados y válidos estilos y ritmos de aprendizajes que poseen los miembros de esta generación. La atención desarrolladora a los distintos modos de aprender, debido a los diferentes estilos, ritmos y talentos, y con ello la atención a una diversidad, nunca antes fue puesta en evidencia, ni tomada en consideración (Ferreiro R., 2000).

Todo lo anterior exige del enseñante y educador el desarrollo de toda una serie de competencias profesionales, pedagógicas y didácticas, posiblemente muy dificultosas de poner en práctica en el contexto de universidad masiva. Uno de los retos que la Net Gen le presenta a sus docentes es básicamente la atención personalizada que requiere y demanda en contextos sociales de diversidad y el empleo de las TIC de forma extensiva y masiva (Ferreiro R., 2000).

Prensky (2001) utiliza la ya pública denominación de nativos digitales para describir a estos jóvenes. Según el autor, ellos son parlantes nativos de una lengua digital basada en el uso de las computadoras, los videojuegos y el acceso a Internet y los adultos deberíamos concientizar que nos movemos en la sociedad digital pero con acento. Utilizamos la tecnología pero no de la misma forma que la generación actual. De acuerdo con Prensky, cualquier persona nacida a partir de 1980 podría ser considerada un nativo digital, por lo tanto, se trata de los aprendices del nuevo milenio: adolescentes y jóvenes que ocupan distintos niveles del sistema educativo hasta la formación universitaria (Trinder, Guiller, Margaryan, Littlejohn, Nicol, 2008). 


\section{¿Existen diferencias entre los propios estudiantes?}

Si bien hay una gran diversidad de usos entre la población de estudiantes, en especial parece reconocerse en este estudio que las competencias digitales básicas no precisamente se trasladan al uso de las tecnologías con fines de estudio. Lorenzo, Oblinger y Dziuban (2006:4) aseveran que "no todos los estudiantes se benefician de la tecnología. En la educación superior, existe una alta diversidad de estudiantes con capacidades de alfabetización digital muy variadas". La falta de homogeneidad es uno de los principales resultados de esta investigación, que muestra la relación entre el uso de la tecnología y los estudiantes que ingresan a la universidad durante el primer año (Escofet Roig et al, 2011).

Socializar y conectarse con los demás no constituye el único uso de las tecnologías. En el informe de Trinder et al. (2008) se hace saber que un 59\% de los estudiantes ingleses utilizan con frecuencia la web para sus estudios: para buscar información, acceder a las plataformas virtuales institucionales, comunicarse con los compañeros del curso para realizar trabajos, etcétera. Algo que actualmente ya sucede en las aulas y talleres universitarios en Argentina y Latinoamérica. También, se comprueba que, ciertamente en la práctica, algunos profesores universitarios están proporcionando este tipo de canales para desarrollar las experiencias y prácticas formativas (Escofet Roig et al, 2011).

En la mayoría de las investigaciones se muestra cómo estos instrumentos pueden ser utilizados con éxito en la formación. No obstante, los casos que se presentan en las mismas son prácticas aisladas que, en general están promovidas por profesores entusiastas que no obtienen apoyo o compromiso por parte de la institución. Como afirma un informe, frecuentemente el uso de herramientas web 2.0 supone un vínculo efectivo entre un medio formal y uno informal, aportando a los estudiantes nuevas formas de acceder y captar conocimiento, al conectar el contenido del curso con la experiencia de la vida real (AlaMutka et al., 2009).

\section{Algunos conceptos para reflexionar}

Si algo está claro es que este tipo de temática está lejos de cerrarse o que se arribe a conclusiones definitivas. La Net Gen es una generación diferente, como todas la han sido en su momento, pero con sorprendentes y variadas perspectivas por el momento histórico que le toca vivir. Compone el porcentaje mayoritario en términos estadísticos y demográficos de la sociedad contemporánea. Por caso, sólo en los EEUU son algo más de 88 millones, mucho más de lo que en su época fue la Baby Boomer. Crean a su vez un reto a nivel social general, en los procesos de democratización, comercio y mercado, entretenimiento y diversión, y ciertamente en las instituciones tradicionalmente dedicadas a la formación de las nuevas generaciones (Ferreiro R., 2000).

Concluyendo estas reflexiones y aportes se podría señalar que, para su inserción en un sistema que posibilite su pleno desarrollo, la generación Net requiere el pasaje de:

Aprendizaje lineal a...... nuevos contextos de aprendizaje.

Enseñanza repetidora y memorística a...... construcción social del conocimiento. 
Aprendizaje competitivo a...... aprendizaje cooperativo. Enseñanza individualista a...... interdependencia social.

Docente trasmisor a......docente mediador.

Aprendizaje institucional a.......aprendizaje permanente e ilimitado en tiempo/espacio. Aprendizaje por compromiso u obligación a...... aprendizaje por placer.

Aprendizaje centrado en docente y contenido a......aprendizaje centrado en el desarrollo personal, técnico y profesional del estudiante.

La generación Net no es mejor o peor que otras en su momento. Eso sí, tiene extraordinarias potencialidades y posibilidades dado su momento histórico, y lo que es su principal capital respecto de anteriores generaciones: participan de manera activa en la construcción del conocimiento. De nuestra atención desarrolladora y acompañamiento dependerá en gran medida su correcta inserción y contribución social (Ferreiro R., 2000).

Hay que reconocer que nunca antes como ahora, históricamente se han estudiado y tenido en cuenta las particularidades de las nuevas generaciones con vistas a encarar metodologías de enseñanza. Ello se debe a diversos factores, uno de ellos, son los contundentes rasgos propios y diferencias con generaciones anteriores.

Gestionar de forma inteligente los contrastes entre los miembros de una institución, se refiere a considerar las particularidades generacionales con todo lo que ello implica, haciendo foco en las formas de comunicación, factores que los motivan, y en particular en tener la capacidad de aprovechar esas diferencias como valores agregados, y no como obstáculos, que impulsen el desarrollo de las tareas en común. Implementar estrategias de comunicación efectivas que permitan a las personas conocer los diferentes puntos de vista de cada una de estas y así aspirar a disminuir los prejuicios que se pueden generar sobre las actitudes y comportamientos de los miembros de cada generación. Identificar las diferencias generacionales en base a sus valores, comportamientos, perfil, trabajo e influencias. Es una ardua tarea que compete a las instituciones y enseñantes de hoy.

Vale imaginar que en un futuro próximo los miembros de las generaciones Baby Boomers y $X$, que hoy asumen los roles en docencia y autoridad institucional, serán reemplazados en esos roles por los Nets, hoy aprendices, con todas sus variantes, ...supuestamente estarían resueltas las dificultades de enseñanza-aprendizaje que representan hoy las diferencias generacionales y de paradigmas... no es tan fácil prefigurar cuáles serán las nuevas generaciones de aprendices ni los nuevos paradigmas que moldearán sus estructuras, cuáles tecnologías y avances científicos manejarán o los manejarán a ellos... ni la velocidad de los cambios y contextos sociales....tal vez habrá que dejar estas fantasías para los creadores de ciencia-ficción.

\section{Referencias bibliográficas}

Ala-Mutka, K.; Bacigalupo, M.; Kluzer, S.; Pascu, C.; Punie, Y. y Redecker, C. (2009). Learning 2.0: The impact of Web 2.0. Innovations on education and training in Europe. Institute for Prospective Technological Studies. Joint Research Centre. European Commission. Disponible en: http://ipts.jrc.ec.europa.eu/publications/pub.cfm?id=2139. 
Castells, M. (1997-98). La era de la información (3 vols.). Madrid: Alianza.

Castells, M. (2001). La galaxia Internet. España: Ed. Arete.

Coupland D. (1991). Generation X: Tales for an Accelerated Culture. Nueva York: St. Martin's Press.

Downes, S. (2004). Educational blogging, Educause Review, 39(5). Disponible http://connect. educause.edu/Library/educause+Review/EducationalBlogging/40493

European Commission (2001). Communication: Making a European area of lifelong learning a reality. Disponible en: http://www.europa.eu.int/comm/education/life/index.htm

Ferreiro, R. (2000). Nuevos ambientes de aprendizaje, INPUT. No. 21, Barcelona. pp. 72-74.

Kahnwald, N. (2009). Social software as a tool for informal learning, Elearning Europa, Disponible en: http://www.elearningeuropa.info/files/media/media19951.pdf.

Kostyrka-Allchorne K., Cooper NR, Simpson A. (2017). Touchscreen generation: children's current media use, parental supervision methods and attitudes towards contemporary media. Acta Podiatrica; 106: 654-662.

Lévy, P. (1998). Becoming virtual: reality in the Digital Age. Nueva York: Plenum Trade.

McLuhan, M. (1971). Guerra y paz en la aldea global. Barcelona: Martínez Roca.

Monereo, C. (2004). La construcción virtual de la mente: implicaciones psicoeducativas, Interactive Educational Multimedia, 9. Disponible en: http://www.ub.edu/multimedia/ iem/down/c9/Construction_of_the_mind_\%28SPA\%29.pdf

Negroponte, N. (1995). El mundo digital. Barcelona: Ediciones B.

Negroponte, N. (1996). Ser digital. México: Océano.

Prensky, M. (2001). Digital Natives, digital inmigrants, On the Horizon, 9 (5). Disponible en: http://www.marcprensky.com/writing/Prensky\%20-\%20Digital\%20Natives,\%20 Digital\%20Immigrants\%20-\%20Part1.pdf

Prensky, M. (2009). H. sapiens digital: From digital immigrants and digital natives to digital wisdom, Innovate, 5 (3). Disponible en: http://www.innovateonline.info/pdf/vol5_ issue3/H._Sapiens_Digital___From_Digital_Immigrants_and_Digital_Natives_to_ Digital_Wisdom.pdf

Tapscott, D. (1998). Growing up digital: The rise of the Net generation. Nueva York: McGraw-Hill.

Trinder, K; Guiller, J; Margaryan, A.; Littlejohn, A; Nicol, D. (2008). Learning from digital natives: bridging formal and informal learning. Research project report. The Higher Education Academy. Glasgow Caledonian University. Disponible en: http://www.academy. gcal.ac.uk/ldn/LDNFinalReport.pdf.

3er Encuentro BID de Enseñanza y Diseño, Madrid (2011). Disponible en: http://bid-dimad. org/encuentro/documentos/Memoria_3er-Encuentro-BID.pdf

$5^{\circ}$ Encuentro BID De Centros Iberoamericanos De Enseñanza De Diseño, (2013) Central de Diseño /Matadero Madrid. Disponible en: http://bid-dimad.org/septimoencuentro/ wp-content/uploads/2017/04/firmantes-encuentro.pdf

$6^{\circ}$ Encuentro Bid De Centros Iberoamericanos De Enseñanza De Diseño, (2015), Central de Diseño, Matadero, Madrid Organiza: DIMAD. Disponible en: http://bid-dimad.org/ sextoencuentro/innovacion-docente/

7o Encuentro Bid De Centros Iberoamericanos de Enseñanza de Diseño, (2017), Central de Diseño, Matadero, Madrid Organiza: DIMAD. Disponible en: http://bid-dimad.org/ septimoencuentro/es/disenar-para-un-mundo-complejo-2/ 
Abstract: Teaching-learning design poses challenges in the context of the current global paradigm. The generations of Baby-Boomers (1945-60) and X (1961-79), trained in times of cold war, are the didactic organizers of the NET generations or of digital natives: Millenials (1980-1993), Z (1994- 2009) and Touch (2010-today). Quantitative and qualitative changes occur at an accelerated speed in the economic, political, social, environmental, technological and symbolic dimensions from the end of the 20th century and the beginning of the 21st. New teaching / learning modalities product of generational changes, invite critical reflection.

Keywords: teaching - learning - design - changes - models - generations - critical reflection - context.

Resumo: $O$ design de ensino-aprendizagem apresenta desafios no contexto do atual paradigma global. As gerações de Baby-Boomers (1945-60) e X (1961-79), treinados em tempos de guerra fria, são os organizadores didáticos das gerações NET ou dos nativos digitais: Millenials (1980-1993), Z (1994-2009) e Touch (2010-hoje). As mudanças quantitativos e qualitativos são produzidos a uma velocidade acelerada nas dimensões econômica, política, social, ambiental, tecnológica e simbólica a partir do final do século XX e início do XXI. Novas modalidades de ensino / aprendizagem produto de mudanças geracionais, convidam à reflexão crítica.

Palavras chave: Ensino - aprendizagem - design - mudanças - modelos - gerações - reflexão crítica - contexto.

[Las traducciones de los abstracts fueron supervisadas por el autor de cada artículo] 


\section{Identidad y nacionalismo. Una mirada sobre la búsqueda de identidad y nuevas tendencias en el diseño de modas}

María Florencia Bertuzzi ${ }^{\star}$ y Daniela Escobar ${ }^{\star *}$

\begin{abstract}
Resumen: Hablar de la situación en la que el mundo se encuentra actualmente resulta contradictorio. Por un lado, es innegable la masificación que produce la globalización, por tanto, la unidad existente entre los distintos países y las nuevas formas de comunicación y acceso a la información posibilitan la conexión instantánea a nivel global; mientras que por otro lado hay una enorme necesidad de diferenciación y, en este sentido, la vuelta a las raíces y la exploración dentro del territorio de origen han dado un nuevo sentido a la moda y le ha otorgado un nuevo rol al diseñador de indumentaria. La búsqueda de una identidad marcada se genera a partir de la reivindicación de técnicas textiles ancestrales, experimentación textil, sustentabilidad, slow fashion y upcycling, nacionalismo a flor de piel, funcionalidad de la mano con textiles inteligentes, entre otras tendencias en materia de diseño de indumentaria.
\end{abstract}

Palabras clave: moda - tendencias - Diseño de indumentaria - moda consciente - sustentabilidad - nuevo lujo - resiliencia.

[Resúmenes en inglés y portugués en las páginas 126-127]

${ }^{(*)}$ Diseñadora Textil y de Indumentaria (UP, 2012). Desde el año 2013 se desempeña como docente universitaria (UP y UNNOBA). Cursó el Programa de Formación y Capacitación Docente (UP). Actualmente se encuentra cursando un Posgrado de Especialización en Docencia Universitaria (Unnoba). Participa como coordinadora de una feria de diseño en Junín, Buenos Aires y se encuentra desarrollando un proyecto de lencería de diseño independiente.

${ }^{(*)}$ Diseñadora Textil y de indumentaria (UP, 2011). Asesora de imagen personal y corporativa (COE, 2009). Cursó el Programa de Formación y Capacitación Docente (UP, 2014) Profesora de la Universidad de Palermo en el Área de Moda y Tendencias de la facultad de Diseño y Comunicación.

Desde el año 2011 se desempeña como diseñadora de indumentaria y modelista independiente. Participa activamente del diseño de vestuario para cortos independientes. Actualmente dirige su propia marca de Diseño de Alta Costura. Forma parte del Equipo de Evaluación de Proyectos de Graduación y el Cuerpo Académico de Tutorías de la Facultad de Diseño y Comunicación de la Universidad de Palermo. 


\section{Introducción: un acercamiento a la moda argentina}

La moda ha dejado de ser tal y como se la conocía. Ha perdido en gran parte su carácter hegemónico y los centros productores de moda y tendencia, aquellas ciudades del primer mundo que no admitían ningún tipo de competencia, hoy se deben enfrentar a propuestas creativas que surgen de lugares anteriormente impensados. Es el caso de Argentina, quien se ha impuesto tanto en la región -junto a Brasil y Colombia- como a nivel global, como un laboratorio de tendencias a partir del desarrollo de indumentaria con una marcada identidad despegándose por primera vez en la historia de los mandatos europeos.

El caso argentino resulta interesante de analizar ya que desde los tiempos de la colonia la moda reflejaba la heredada cultura europea. Desde aquel entonces, los argentinos han creído que la industria nacional era de baja calidad en relación a las casas de moda extranjeras, de la misma manera se ha relacionado por décadas a la indumentaria importada con productos de lujo. En este sentido, el desarrollo de indumentaria en el país siempre ha mirado al viejo continente, ya por el año 1920 las mujeres adineradas viajaban a Europa para traer sus vestidos de París o, en caso de no poder hacerlo, los recibían a través de comisionistas que se dedicaban a traer vestidos al país para poder vendérselos a las mujeres porteñas de clase alta.

La moda en la Argentina siempre ha estado vinculada al sentir europeo que durante mucho tiempo se hizo parte de la identidad nacional, no porque el argentino no valore sus raíces autóctonas, sino porque a raíz de las inmigraciones provenientes de Europa hasta mediados del siglo XX, la población criolla ha incorporado gran parte de la cultura del viejo continente y, por lo tanto, se siente parte de ella. Esta situación, sencillamente, se puede observar, entre otras cosas, en las formas vestimentarias tanto de las mujeres como de los hombres argentinos.

Según un informe acerca del perfil migratorio de la Argentina realizado por la Organización Internacional para las Migraciones -OIM- (2008):

La inmigración transoceánica que tuvo lugar a partir de mediados del siglo XIX contribuyó de manera esencial al poblamiento del país, aportando en el período 1881-1914 algo más de 4.200.000 personas. De entre ellos, las comunidades predominantes fueron: italiana (2.000.000), española (1.400.000), francesa (170.000) y rusa (160.000). Las corrientes más numerosas se manifestaron antes de la primera guerra mundial; tal es así que en 1914 el stock de inmigrantes en el país alcanzó su máximo nivel histórico, en términos relativos, con un impacto del 30\% en el total de la población (p. 7).

Luego de la década del 60', ya en pleno proceso de globalización -o mundialización-y con una marcada economía capitalista, Argentina empieza a considerar y a consumir también la moda proveniente de Estados Unidos, que ya se imponía como una potencia mundial y como un nuevo centro productor de modas y tendencias.

El sistema productivo de indumentaria en nuestro país, hasta hace algunas décadas, se ha caracterizado por ser imitativo, ha copiado y replicado vestimentas de los diseñadores más reconocidos a nivel internacional para obtener productos capaces de competir en el 
mercado local, aunque no a nivel mundial. De alguna manera, las marcas nacionales, hasta aquel momento, no tomaban conciencia de que dentro de su propio territorio podrían encontrar los recursos necesarios para proyectarse al mundo con sus proyectos creativos. Por este motivo en la década de 1980, a partir del otorgamiento de unos créditos italianos para la fabricación de indumentaria, tal y como lo menciona Susana Saulquin en una entrevista otorgada al diario La Nación (2009), se decide crear la carrera de Diseño de indumentaria y Textil en la Universidad de Buenos Aires (UBA) en abril de 1989. Con esto se pretendía comenzar a generar moda y diseño con impronta nacional y alejarse de la copia de productos extranjeros. Si bien la intención era más que interesante, durante la década del 90' con la política económica del 1 a 1, el gobierno abrió las importaciones y el diseño argentino nuevamente quedó relegado a merced de un mercado muy competitivo en el cual la industria nacional no encontraba su lugar.

Con la crisis económica y política que el país afrontó en el año 2001, la cual se considera un antes y un después en relación al diseño argentino, el mercado comenzó a fluctuar producto del contexto político, social y económico que se vivía por aquellos tiempos y se reavivó el espíritu emprendedor de la mano de jóvenes diseñadores muy creativos. Dicha crisis catapultó al diseño argentino hacia el mundo, integrándolo en el contexto global de la moda.

El advenimiento del diseño de autor y cierta revalorización de lo artesanal ocurrido a partir del año 2000 en nuestro país abrió las puertas de una nueva cultura apoyada en la relectura de técnicas, materiales, e identidades, dormidas y marginadas frente al dictado de la producción masiva y el global star system del diseño. El resultado de ello ha sido, con mayor o menor suerte, una variedad de diseños, que oscilan entre las actuaciones más tecnológicas y las más creativas, y en los que conviven aquellos desarrollos de fuerte impronta identitaria y local, muchas veces mixturados con una cultura artesanal, junto a proyectos de base industrial y tech, ambos con vocación de proyectarse más allá de las estrechas fronteras nacionales (Lebendiker en Mercado de Industrias Creativas de Argentina, 2017, s/d).

En este sentido, coincidiendo con el pensamiento de Laureano Mon (2013) es posible determinar que la imaginación y la creatividad, más que las grandes inversiones de capital, son el ADN del diseño nacional. La clave ha sido, y sigue siendo, generar productos creativos en los cuales se fusionen características del contexto local con la tan anhelada estética global a fin de obtener indumentaria competitiva a nivel internacional.

De esta manera, cabe destacar que la moda como tal no es inherente de la cultura, la sociedad y el contexto en el que se encuentre. Frédéric Godart (2012) asegura que "La moda es un hecho social total, ya que es simultáneamente artístico, económico, político, sociológico... y afecta el tema de la expresión de la identidad social" (p. 17). En tanto, resulta ilógico pensar en la moda argentina sin analizar el recorrido que ha tenido que atravesar para, por fin, lograr que la indumentaria conocida en la actualidad como de autor, exprese el bagaje cultural, social, económico y también político que compone la identidad argentina, la cual se vincula más con la diversidad y la mezcla cultural que caracteriza a los habitantes del territorio. 


\section{Piensa global, actúa local: diseño argentino para el mundo}

Como se ha planteado anteriormente, pensar la moda como un hecho aislado del entorno es algo ilógico, por lo tanto, resulta de interés analizar brevemente el contexto actual en el cual se producen las tendencias y surge la indumentaria que, en algunos casos se convierte en moda y en otros, sin embargo, se presenta como una herramienta o un mensaje a través del cual es posible comunicar la identidad, ya sea del diseñador o de una nación.

Hablar del contexto actual requiere de un análisis profundo, los medios masivos y tecnológicos impulsados hace ya varias décadas son, en gran parte, los protagonistas de la era digital, la cual predispone cambios en las formas de comunicación principalmente, pero también en la estructuración del trabajo -como el trabajo colaborativo, el co-diseño y el networking-, permitiendo nuevas maneras de relacionarse y de llevar a cabo proyectos en cualquier parte del mundo.

Es evidente que, en este mundo globalizado, fluctuante y con cambios constantes, la moda de masas ha encontrado su contexto ideal en tanto le permite renovarse y expandirse al mundo, pero el diseño con identidad, alejado de las tendencias imperantes, se ha podido mantener en el mercado a través de propuestas que apuestan a la creatividad y a la diferenciación en un mundo que pretende la unidad.

La situación actual que vive la humanidad se caracteriza por un proceso acelerado de cambios: caída de referentes históricos, reordenamiento del mundo, el tiempo y el espacio, provocados por la globalización; búsqueda de nuevos paradigmas, estructuración de una cultura planetaria articulada a las necesidades del mercado que niega o instrumentaliza la diversidad y la diferencia (Guerrero Arias, 2002, p. 15).

Hablar de globalización implica, como plantea Colzani (2014), una contradicción, en tanto que sugiere un contexto mundialmente unificado que se caracteriza principalmente por la búsqueda imperiosa de diferenciación por parte de los individuos. Y en esta búsqueda, la vuelta a las raíces, el mirar hacia adentro o al entorno más cercano, resulta ser una buena estrategia de diferenciación entre pares y, sobre todo, una herramienta muy interesante para los diseñadores emergentes. Durante décadas el entorno cercano, los recursos que proveía el territorio y las técnicas textiles ancestrales no se habían tenido en cuenta para el desarrollo de indumentaria en el país, teniendo en cuenta que, haciendo una retrospectiva de la moda en Argentina, es posible determinar que la identidad se buscaba en torno a las raíces europeas.

Cabe destacar que a menudo se vincula el concepto de identidad con lo autóctono, con lo meramente nacional y, si se realiza un análisis de la identidad argentina, es posible determinar que no necesariamente está vinculada con lo anteriormente mencionado. Precisamente el diseño argentino parece estar más en sintonía con el lema contemporáneo "piensa global y actúa local", teniendo en cuenta que fusiona de manera efectiva técnicas industriales y artesanales en su producción, mixturando el sentir europeo con lo netamente autóctono, principalmente en relación a las materialidades y técnicas de revalorización textil artesanales. 
Como nuevas formas sustentables de pensar la producción que se apartan de la masividad, resulta interesante considerar el desarrollo de las habilidades locales, por ejemplo, la confección de artesanías y el uso de los materiales de cada lugar para comercializarlos globalmente ("glocalización”).

En el caso especial de Argentina, se abren oportunidades a partir del reconocimiento cada vez más importante de los camélidos: llamas, guanacos y vicuñas, que aportan autenticidad y tradición cultural como nuevo valor" (Saulquin, 2014, p. 46).

En este contexto, globalizado y con una inmensa necesidad de mantenerse actualizado constantemente, las nuevas formas de comunicación han jugado un papel importante en torno al desarrollo de nuevos proyectos creativos y emprendimientos. Ya no resulta imprescindible estar presente físicamente para entablar relaciones laborales o emprender nuevos proyectos, en tanto los avances tecnológicos han hecho posible nuevas estructuras de negocios que permiten estar conectados y comunicados a kilómetros de distancia pudiendo trabajar colaborativamente y poniendo en valor a todos los participantes de la cadena de producción, incluso trabajando conjuntamente entre diseñadores (co-diseño) o con personas pertenecientes o descendientes de los pueblos originarios implementando técnicas textiles artesanales para sus diseños (cooperativismo) a partir de los principios del comercio justo.

Hoy en día, sigue estando muy arraigada la creencia, tanto en diseñadores como en consumidores de moda y usuarios, de que la moda con impronta o identidad nacional consta de una traducción o copia literal de la vestimenta o diseños folclóricos representativos de la cultura étnica de un país. Esta premisa no sólo resulta antigua, sino que otorga una mirada parcializada sobre el proceso de diseño que implica no sólo el análisis histórico, la evaluación de materias primas autóctonas (y/o presentes en el territorio), el análisis y aplicación de tendencias mundiales latentes (no estacionales, sino a nivel macro ya que se involucran procesos éticos, sustentables y políticos) para generar un proceso de hibridación en relación a la identidad de cada autor determinado.

Es decir, que la toma de partido hacia una moda nacionalista no responde simplemente a cumplir con una tendencia boho o hippie chic, sino que engloba una inquietud más profunda en relación a varios aspectos a tener en cuenta.

En primer lugar, como se ha mencionado anteriormente, el análisis histórico del ambiente que se habita resulta muy enriquecedor en cuanto a las tipologías vestimentarias utilizadas en el país, así como también los accesorios utilizados y, en concordancia, se pueden explorar diferentes materias primas y técnicas de manufacturación artesanal, como así también técnicas ancestrales de adorno u ornamentación. Si se estudia específicamente al territorio argentino, se encuentran numerosas materialidades textiles muy ricas para la producción de indumentaria, calzado, accesorios y diversos objetos del vestir.

Según Henrik Kuffner (asesor técnico en fibras naturales para el proyecto "Mejora de las Economías Regionales y Desarrollo Local” ejecutado por el Instituto Nacional de Tecnología Industrial -INTI- con el apoyo de la Unión Europea) en relación a las fibras naturales argentinas, existen dos tendencias mundiales que favorecen el posicionamiento argentino en el escenario de la moda: 
Por un lado, la búsqueda de originalidad que manifiestan los consumidores se profundiza. El deseo de tener esa pieza única, hecha a mano y con una historia detrás privilegia el trabajo artesanal y viene a compensar el avance de la moda en serie. Por otro lado la valoración de las fibras exóticas se vincula con que fuera del mercado de moda masivo, "la sustentabilidad es la clave" e impacta en la decisión de compra. La buena calidad es tan importante como la trazabilidad del proceso de elaboración de los productos (Lázaro, 2015).

En este sentido, es importante destacar la valorización de las fibras exóticas presentes en el territorio argentino, principalmente la lana de llama y vicuña muy valorizada por países europeos. Marcas argentinas y diseñadores independientes utilizan la vicuña, el lino y el algodón, así como también el cuero producido en territorio argentino en sus colecciones y exportan sus productos a países lejanos.

La marca emergente Pier revaloriza la vestimenta autóctona argentina, utilizando materiales como el cuero y el chaguar. La diseñadora Catalina Pieres da especial valor al trabajo artesanal y la materia prima argentina, así como también cree en una nueva economía en donde el consumidor compre conscientemente y elija un producto que prevalezca en el tiempo y esté hecho en condiciones dignas.

Otro ejemplo es la marca Cúbreme, la cual utiliza en todas sus colecciones lana merino orgánica y lana de llama. Se conjugan la utilización de materiales autóctonos con el ideal de comercio justo y ropa $100 \%$ ecológica (ya que la llama es un animal doméstico y no hay que capturarlo para proceder a su esquila).

Hay diseñadores ya consagrados que han enarbolado la bandera de lo autóctono con una resignificación importante de diseño y que no utilizan la materia prima en estado natural, sino que se basan en técnicas textiles ancestrales como Marcelo Senra, quien utiliza el chaguar, Manuela Rasjido y el barracán y Juana de Arco quien usa el ñandutí.

El diseñador Santos Liendro, va un poco más allá, y comunica perfectamente la cultura argentina andina en una perfecta conjunción entre arte ancestral y proceso de diseño Esto se traduce en accesorios hechos en alpaca, piedras del norte salteño y ónix, y el diseño de tejidos artesanales mixturados con tejidos de manufactura industrial.

\section{La nueva ideología de la moda}

Todo cambio implica una nueva toma de partido y un nuevo comienzo. En este sentido, el cambio de paradigma en la moda ha impulsado un nuevo rol del diseñador de indumentaria y, por lo tanto, nuevas formas de desarrollar prendas de vestir en sintonía con el entorno y enfocada a los usuarios, los cuales se muestran más conscientes y permeables a vivir nuevas experiencias a través de la indumentaria. Anteriormente la mayor preocupación de un creador de moda era la de estar informado y actualizado en relación a las tendencias a nivel macro, poder brindar indumentos con impronta global, lograr una imagen cosmopolita. En la actualidad, con la gran cantidad de información que circula en las redes y en los medios tradicionales de comunicación, las exigencias de los usuarios se han exacerbado, teniendo en cuenta que se encuentran mucho más actualizados e in- 
formados y, por lo tanto, no solo están al tanto de las tendencias, sino que también han aprendido acerca del valor del cuidado medioambiental, del impacto que genera la moda en el entorno y, principalmente, le han dado valor a lo artesanal por sobre lo meramente industrializado.

Es posible determinar que el sistema de la moda, en el inicio del siglo XXI, ha cambiado rotundamente su ideología rectora, pasando de la producción masiva al cuidado de los recursos, dando como resultado lo que hoy se conoce como moda ética en la cual se enmarcan muchos de los proyectos de los diseñadores emergentes argentinos.

Durante la vigencia de la cultura de masas, cuando se impulsaban los consumos a partir de las estrategias que hacían homogéneas las formas, estandarizaban las medidas, vulgarizaban las prendas al simplificarlas y se orientaban a los mercados democráticamente, se desatendían las verdaderas necesidades de las personas. Desde esa situación de búsquedas ficticias, la sociedad actual necesita para su supervivencia hacer cambios tanto en la manera de producir las prendas como en la manera de apropiarse de ellas (Saulquin, 2014, p. 53).

Este cambio ideológico del sistema de la moda ha beneficiado a la gran mayoría de los países latinoamericanos los cuales mantienen una relación muy estrecha con sus recursos naturales, sus técnicas de manufacturación ancestrales y, principalmente, con la producción de fibras textiles orgánicas las cuales son consideradas parte del nuevo lujo del siglo XXI. Asimismo, este nuevo paradigma de la moda, no solo ha puesto en valor lo autóctono y lo artesanal, sino que ha impactado directamente sobre las formas de producción. Al combinar procesos industriales con artesanales en las prendas, los diseñadores de indumentaria han tenido que aprender a conectarse con tiempos de producción más humanos, de esta forma el proceso creativo se vuelve más personalizado y en coherencia con las verdaderas necesidades del usuario. En tal sentido, los tiempos de producción ya no responden a las exigencias de la industria sino de los usuarios, quienes valoran la calidad y el trabajo artesanal que proporciona una historia detrás de cada prenda.

A partir de la revalorización del trabajo artesanal, en el año 2015 se creó en el país el Registro Nacional de Artesanos Textiles de la República Argentina, el cual permite fomentar y registrar la actividad artesanal textil en el territorio, así como también permitir a los artesanos una visibilidad local y mundial de su trabajo.

El ReNATRA es una guía que reúne datos esenciales de cada artesano textil argentino: su nombre propio, la denominación de su emprendimiento, dirección y contacto tecnológico, la actividad artesanal que realiza (hilandería, tejeduría o ambas) y la técnica de tejido que emplea: de punto, de red, a telar, trenzados $\mathrm{u}$ otras técnicas textiles.

Mucha gente trabajó para concretar esta guía, ahora fuente de consulta de acceso público y gratuito. Para generarla, fue vital que se enlazaran múltiples organismos e instituciones (más de 250): del Estado Nacional, gobiernos provinciales y municipales, ONG's y fundaciones (Vallejos, 2015). 
Esta base de datos pretende vincular a los diseñadores de indumentaria y textil con los artesanos para que estos últimos se puedan incorporar al sistema de la moda bajo el criterio de la moda ética y el comercio justo, favoreciendo de esta manera al desarrollo de las economías regionales.

Hay diseñadores argentinos famosos que en las últimas décadas se esforzaron -por convicción y buen gusto- en abrir el camino para que la artesanía textil sea parte de la moda y suba a la pasarela, para luego recorrer el mundo urbano (Vallejos, 2015).

Como bien se ha mencionado anteriormente, el entorno cercano nutre al diseño de indumentaria y textil argentino -y también a nivel latinoamericano- para el desarrollo de emprendimientos con identidad. Asimismo, la tendencia latente acerca del cuidado medioambiental y de los recursos naturales, conjuntamente con la crisis económica, son factores que se conjugan para converger en lo que se conoce actualmente como moda ética, eco moda o moda sustentable. En tal sentido, cabe destacar, que sin crisis no hay cambio, por lo que todos estos nuevos emprendimientos que se han generado a partir de estos nuevos criterios de la moda son producto de las crisis que se afrontan en la actualidad, ya sea medioambiental, social, política, cultural o económica.

A medida que avanza el siglo actual y cumpliendo con su ideología rectora, se afianza cada vez más entre los creadores independientes la importancia del diseño sustentable, con producciones basadas en la ética y en la responsabilidad social. En la actualidad, las formas de producción y reproducción de vestimentas comenzarán a ser prestigiosas en la medida que puedan responder y reflejar la ideología del siglo XXI, contemplando el cuidado de los recursos naturales y de las personas (Saulquin, 2014, p. 90).

En Argentina hay muchos emprendimientos, hoy devenidos en negocios sustentables, que se enmarcan dentro de lo que se conoce como upcycling. Transforman materiales aparentemente de desecho para darles una nueva vida útil y convertirlos en objetos de diseño aportando al cuidado medioambiental y a mejorar la relación que se tiene con el entorno, asimismo ayudando a fomentar y a tomar consciencia acerca del impacto que generan los residuos en el ambiente.

Jessica Pullo apuesta al upcycling para el desarrollo de su marca Biótico. Para la creación de sus prendas apuesta a la reutilización de desechos domésticos urbanos, como sachets de leche, bolsas de nylon, plásticos blancos, descartes textiles y packaging. Asimismo, trabaja colaborativamente con integrantes de la Asociación Laboral para Adultos con Discapacidad Intelectual (Alpad) quienes realizan trabajo sobre los desechos que luego se convertirán en prendas de indumentaria.

La marca de accesorios Modesta también es un caso específico de moda sustentable y upcycling, teniendo en cuenta que apuestan a la reutilización de bolsas plásticas para el desarrollo de carteras, bolsos y sombreros. Cabe destacar que para poder confeccionar un bolso de la marca se necesitan entre 50 y 100 bolsas plásticas. 
Vale la pena mencionar a su vez, a la marca Carro, autodenominada como 'creadora de objetos portantes', es decir que, realizan todo tipo de accesorios contenedores como mochilas, bolsos, morrales y fundas para tablet, notebook, etc. Carro nació en el año 2007, de la mano de las diseñadoras Guillermina Balsells y Silvina Cannito, quienes luego de un viaje a Europa en busca de tendencias, vieron la oportunidad de crear objetos nuevos a partir de prendas en desuso. De este modo, la marca selecciona indumentaria de descarte y reutiliza los textiles rescatados para crear nuevos accesorios portantes.

A través de la deconstrucción de prendas en desuso en combinación con nuevas materialidades trabajan los diseñadores argentinos Mercedes Martinez y Mariano Breccia, dueños de la marca $12 \mathrm{Na}$, la cual se encuentra localizada en Chile pero que tiene proyección tanto en Latinoamérica con en el resto del mundo. Ellos realizan indumentaria mediante la intervención de ropa de segunda mano, retazos de descartes industriales y telas recicladas. De esta manera, crean indumentaria única, original y divertida. Sus prendas se encuentran a la venta en Santiago de Chile, Buenos Aires y Tokio, con posibilidades de expansión hacia otros países asiáticos. Además, realizan vestuario para reconocidos músicos y artistas latinos como El Chavez, los Illia Kuriaky and the Valderramas y los chilenos Fernando Milagros, Gepe y Javiera Mena.

Una significativa macrotendencia a nivel global ha sido mencionada anteriormente: el nuevo lujo. Esta corriente que se impone hace aproximadamente una década y llegó para quedarse, engloba todos los conceptos a los que se ha hecho mención con anterioridad: la sustentabilidad, la atemporalidad, el diseño 'a medida' o customizado y, sobre todo, la conciencia ecológica. "Se trata de volver a la esencia del lujo, a su significado ancestral, la compra meditada, la manufactura artesanal y la belleza de los materiales en su sentido más amplio" (Gardetti, 2013).

Esta nueva búsqueda de lujo, desterrando la antigua concepción de lujo banal, recargado, relativo a precios elevados, privativo para las clases más altas y relacionado con la explotación de materiales sin importar la conciencia medioambiental, es una premisa que se repite en los diseñadores emergentes y resulta su forma de contribuir hacia una nueva moda ética, comprometida y responsable.

Hay un nuevo lujo que no tiene que ver con un producto sofisticado ni carísimo, sino con lo artesanal, en materiales naturales, confeccionado de manera exclusiva, respetando el medio ambiente y las condiciones en que trabajan quienes lo producen. Lo hecho a mano es un lujo. Implica una adquisición meditada, que lo valora; se opone a la compra inconsciente (Vitale, 2016).

Además, en su esencia, el lujo y el desarrollo sustentable van de la mano. Las marcas premium venden productos escasos, dependen de los recursos naturales y la confección artesanal. El lujo promueve una cultura opuesta al usar y tirar nada más lejos del fast fashion; se trata de productos de alta durabilidad y se pasan de generación en generación. Asimismo, requieren de mano de obra calificada, por lo que promueven habilidades especializadas y capacitan a los empleados (Vitale, 2016). 
Si bien todos los ejemplos mencionados anteriormente corresponden con este ideal de nuevo lujo, cabe mencionar algunos otros ejemplos de aplicación de esta nueva mirada sobre el mundo de la moda, las cuales han sido premiadas y galardonadas por su actividad responsable.

En primer lugar, cabe destacar el trabajo de los diseñadores argentinos Ezequiel Gatti, Nazareno El Hom y Alejandro Malgor quienes fabrican zapatillas a partir de residuos de caucho de neumáticos y con retazos de jeans, mamelucos de cortinas desechadas y de otros textiles. La marca Xinca ha sido reconocida como el mejor emprendimiento sustentable del país, y también Naciones Unidas les otorgó el premio GSC 3S (premio mediante el cual se reconoce el trabajo de pequeñas empresas que implementan y promueven innovaciones y prácticas sustentables y socialmente responsables).

En 2013, fue nominada al Premio al mejor desempeño en lujo sustentable en Latinoamérica la diseñadora argentina Lori Carini, creadora de la marca Visceral Argentina, la cual trabaja con mondongo (estómago de vaca) como materia prima fundamental para realizar todo tipo de calzado. Además de la utilización de un material poco convencional, el carácter sustentable y el aprovechamiento de los recursos se encuentra en el proceso de curtido ya que se reutiliza el agua con el que se hace y se utilizan taninos vegetales. Luego de que esos elementos se agotan, se utilizan los desechos como abono.

\section{Conclusiones}

Habrá sido, muy probablemente, en el afán de recuperar algo de todo aquello que la era de Internet, las pantallas líquidas y las redes sociales parecía llevarse puesto por completo a finales de los años noventa, que muchos artistas visuales se inclinaron a explorar telas, hilos, lanas y bordados. Algo del orden de lo íntimo y lo doméstico se juega -lo sabemos y ya ha sido dicho- en este tipo de trabajos, en cuya práctica ordinaria anidaron, de forma anónima y durante siglos, secretos, historias, pequeños universos que hoy, a la -tenue- luz de la vida contemporánea, refulgen como piedras preciosas (Villaro, 2018).

Al tratar de pensar en una identidad argentina de diseño, evocamos el típico traje folclórico, el gaucho y la china, la guarda pampa, el mate y el poncho, siendo tal vez, una forma muy fácil de encasillar un concepto tan vasto y abarcativo como es la identidad.

Aunque es importante decir que no está mal hacer uso de los íconos mencionados anteriormente, el verdadero poder significativo de lo nacional es la creación de una verdadera cultura del diseño argentino y de contemplar en éste una auténtica ventana hacia el mundo con una impronta propia y diferente a las demás regiones del planeta sin perder lo que hace al territorio argentino único e inédito para muchos consumidores de moda.

Hablar de identidad corresponde a varios aspectos de una cultura: incluye también los procesos productivos que se utilizan, las materialidades presentes autóctonas y de cada región, la relación que la sociedad tiene con el medio ambiente, la forma de creación de tejidos y procesos de diseño, y, también la personalidad de sus habitantes tanto como los procesos económicos y políticos que atraviesan al país. 
Es común oír en los dichos de diseñadores argentinos que somos hijos de la crisis, y esta es una gran verdad, pero también una cualidad significativa y sólida para otorgar una personalidad resiliente y adaptable a cambios bruscos. Ésta veta, además de las riquezas naturales que posee el territorio argentino, es la que destaca a los creadores de la región en relación a los diseñadores de otras partes del mundo.

Un diseñador de moda no es una isla, sino que se nutre del medio que lo rodea. Por lo tanto, no es indiferente a las tendencias ni a los sucesos que acontecen de forma global, pero, en vez de realizar la antigua copia de tendencias europeas, la nueva generación de diseñadores, analiza y entiende las tendencias latentes para luego seleccionar aquello que se ajusta a su identidad aplicada a su personalidad como creador. De manera que, al momento de generar una identidad nacional, también se busca que la misma sea aplicable en diferentes partes del mundo. Es decir, que sea aceptada y posible de usar en cualquier lugar sin dejar de contar la historia detrás de la prenda.

En cada pieza se comunica una marcada territorialidad, en el cual se manifiesta un acentuado relato que interpreta la riqueza del medio que los rodea, los preciosos recursos naturales con los que se cuenta y el patrimonio cultural que el arte ancestral otorga. A todo esto, es relevante adicionar la genuina preocupación por el medio ambiente y el cuidado de los recursos, de manera que a la valorización de los procesos artesanales (ya sea en materia de tejidos, teñidos y/o utilización de materias primas naturales u orgánicas) se le suma la sustentabilidad y el comercio justo como valores insoslayables. Aquí nace el nuevo lujo, el consumo consciente dando como resultado la consumación de una moda completamente ética.

Para finalizar, es importante destacar que los diseñadores emergentes argentinos y latinoamericanos analizan las opciones que tienen a su alcance, investigan y buscan nuevos materiales para su aprovechamiento, analizan su entorno y medio ambiente, soslayan crisis y vaivenes económicos, buscan incorporar la ética y el comercio justo al mundo de la moda, pero, el rasgo más significativo es que son resilientes y no se detienen, buscan continuamente nuevos horizontes.

\section{Bibliografía}

Brovia, F. (2016). Vestir a consciencia, el nuevo lujo. Buenos Aires: Diario Clarín. Recuperado el 11702/2018. Disponible en: https://www.clarin.com/entremujeres/moda/fashion-tips/ vestir-consciencia-nuevo-lujo_0_rykVv0fHe.html

Colzani, G. (2014). Tejiendo identidades latinoamericanas. Cuadernos del Centro de Estudios de Diseño y Comunicación No 47. Buenos Aires: Universidad de Palermo. Disponible en: http://fido.palermo.edu/servicios_dyc/publicacionesdc/archivos/459_libro.pdf

Gadea Lara, T. (2017). Empresas "ecofriendly" que apuestan por el diseño sustentable. Recuperado el 30/01/2018. Disponible en: https://www.lanacion.com.ar/2015871-empresasecofriendly-que-apuestan-por-el-diseno-sustentable

Gardetti, M. (2013). Nuevo lujo para uno y lo demás. Citado en: Tapia, P. (2013) Nuevo lujo para uno y los demás. Recuperado el 11/02/2018. Disponible en: https://www.clarin. com/mujer/Nuevo-lujo_0_rkHXYDMoPmg.html 
Guerrero Arias, P. (2002). La cultura. Estrategias conceptuales para entender la identidad, diversidad, la alteridad y la diferencia. Quito: Abya-Yala. Disponible en: http://digital repository.unm.edu/abya_yala/10/

Godart, F. (2012). Sociología de la moda. Buenos Aires: Edhasa.

Lázaro, A. (2015). Fibras naturales argentinas. Recuperado el 07/02/2018. Disponible en: https:/lamodaenserio.com/fibras-naturales-argentinas/

Maurello, E. (2016). Carro, trabajando el upcycling desde Argentina. Recuperado el 11/02/2018. Disponible en: https://www.slowfashionnext.com/blog/2016/07/27/carro-trabajando-elupcycling-desde-argentina/

Mercado de Industrias Creativas de Argentina (2017). Dis.Glosario federal del diseño argentino. Santa Fe: Mercado de Industrias Creativas de Argentina (MICA). Consultado el 26/01/2018. Disponible en https://mica.cultura.gob.ar/wp-content/uploads/sites/ 10/2017/10/DisglosarioWeb-MCN.pdf

Mon, L. (2013). Diseño en Argentina. Hacia la construcción de nuevos paradigmas. Cuadernos del Centro de Estudios de Diseño y Comunicación $N^{\circ} 44$. Buenos Aires: Universidad de Palermo.

Montenegro, T. (2012). $12 \mathrm{Na}$, el reciclaje como medio de expresión. Revista Dínamo. Recuperado el 11/02/2018. Disponible en: http://www.revistadinamo.com/?p=2562

Organización Internacional para las Migraciones (2008). Perfil migratorio de Argentina. Buenos Aires: Organización Internacional para las Migraciones. Consultado el 10/01/2018. Disponible en http://www.mininterior.gov.ar/provincias/archivos_prv25/6-\%20Perfil _Migratorio_de_la_Argentina.pdf

Saulquin, S. (2009). Indumentaria. Diario La Nación. Recuperado el 30/01/2018. Disponible en: http://www.lanacion.com.ar/1217023-indumentaria

Saulquin, S. (2014). Política de las apariencias. Paidós: Buenos Aires.

Vallejos, M. (2015). Que se vea, aqui y afuera: la identidad de los artesanos textiles. Recuperado el 07/02/2018. Disponible en: https://lamodaenserio.com/la-identidad-de-losartesanos-textiles/

Villaro, J. (2018). El territorio que cabe en una trama. Buenos Aires: Revista Ñ. Recuperado el 11/02/2018. Disponible en: https://www.clarin.com/revista-enie/arte/territoriotrama_0_BJjpOs1LM.html

Vitale, S. (2016). Cómo es el lujo sustentable. Buenos Aires: Diario La nación. Recuperado el 11/02/2018. Disponible en: https://www.lanacion.com.ar/1899992-como-es-el-lujosustentable

Abstract: Talking about the current worldwide situation is highly contradictory. On the one hand, the massification that globalization produces is undeniable, therefore, the existing unity between the different countries and the new forms of communication and access to information make possible the instantaneous connection at the global level; while on the other hand there is a huge need for differentiation and, in this sense, the return to roots and exploration within the territory of origin have given a new sense to fashion and has given a new role to fashion designers. The search for a marked identity is generated from 
the claim of ancestral textile techniques, textile experimentation, sustainability, slow fashion and upcycling, nationalism to the surface, functionality of the hand with intelligent textiles, among other trends in the design of dress.

Keywords: fashion - trends - Clothing design - conscious fashion - sustainability - new luxury - resilience.

Resumo: Falar sobre a situação em que o mundo é atualmente é contraditório. Por um lado, a massificação que a globalização produz é inegável, portanto, a unidade existente entre os diferentes países e as novas formas de comunicação e acesso à informação possibilitam a conexão instantânea em nível global; enquanto, por outro lado, há uma enorme necessidade de diferenciação e, nesse sentido, o retorno às raízes e a exploração dentro do território de origem deram um novo sentido à moda e deram um novo papel ao designer de roupas. A busca por uma identidade marcante é gerada a partir da reivindicação de técnicas têxteis ancestrais, experimentação têxtil, sustentabilidade, slow fashion e upcycling, nacionalismo à superfície, funcionalidade da mão com tecidos inteligentes, entre outras tendências no design de vestuário.

Palavras-chave: Moda - tendências - Design de roupas - moda consciente - sustentabilidade - novo luxo - resiliência.

[Las traducciones de los abstracts fueron supervisadas por el autor de cada artículo] 



\section{Rembrandt: estética, sujeción y corporalidad}

\author{
Juan Alberto Di Loreto *
}

Resumen: La producción y el contexto del pintor holandés Rembrandt Harmenszoon van Rijn, permite un análisis de diversos cambios en las concepciones de la subjetividad y el cuerpo que se dan en el mundo europeo a comienzos del siglo XVII. A través de las llamadas lecciones de anatomía y sus autorretratos, Rembrandt da cuenta de la racionalización, la aparición del individuo y objetivación de la corporalidad: de un cuerpo unido a la comunidad en la Edad Media, a la representación en la Modernidad de un cuerpo como un objeto inerte; del sujeto comunitario a la percepción del sujeto como unidad.

Palabras clave: subjetividad - Rembrandt - Harmenszoon van Rijn - 1606-1669 - arte barroco - modernidad - estética.

[Resúmenes en inglés y portugués en la página 139]

${ }^{(*)}$ Licenciado en Ciencias de la Comunicación (UBA) y Bibliotecario (Biblioteca Nacional Mariano Moreno), ejerció como docente en Comunicación y Ciencia Política (UBA). Con el foco puesto en el cruce entre el arte, la comunicación y la filosofía colaboró en periódicos y revistas de Buenos Aires y el interior. Actualmente se desempeña como Bibliotecario en la Universidad de Palermo.

Vida, obra, sucesos, ideas: Rembrandt. Un nombre que refiere al emblemático artista barroco pero también al despertar de una época. Porque este significante, "Rembrandt", nos aparece delimitado sincrónicamente por su contemporaneidad, pero (re)significado diacrónicamente por la posteridad. Su vida, sus decisiones, su contexto, su co-texto, su forma de mirar y pintar. En definitiva: qué significó la producción de este artista, qué signos nos dejó que podemos seguir significando.

Pero hay más: el conjunto significante Rembrandt, que podemos agrupar bajo su obra pictórica, reenvía al Sujeto moderno. Así, en mayúsculas, en su sentido fuerte: Sujeto, el Yo, el Cogito cartesiano, el substrato. Porque su obra, por qué tardar en decirlo, es parte de aquel entramado que llamamos Modernidad. En palabras de Eduardo Grüner (2005, p. 17): "es parte de la memoria de la especie, todo un sistema de representaciones que implica a los sujetos sociales en sus representaciones, prácticas y supuestos ideológicos". Pero seamos sinceros, más allá de todo: esto no es más que una interpretación, una búsqueda de causas y efectos entre el relato de una vida, unas prácticas, una sociedad, lecturas filo- 
sóficas e históricas. Al fin y al cabo, un sesgo en el (infinito) entramado semiótico de las interpretaciones.

\section{Rembrandt}

Para comprender mejor la nueva representación del cuerpo humano y la construcción social de la subjetividad que se estaba realizando en el comienzo de la Modernidad a través de la obra artística de Rembrandt, es conveniente hacer una introducción biográfica al personaje, su época y su espacio; en definitiva, situarlo en un contexto determinado para ver sus posibilidades y limitaciones.

Rembrandt Harmensz van Rijn ${ }^{1}$, penúltimo de nueve hijos, nació en la ciudad de Leiden el 15 de julio de 1606, y murió en Ámsterdam en el año de 1669. Leiden, ubicada en la Holanda meridional, cosechó los frutos de una nación pujante gracias al colonialismo y el poderío marítimo, lo que tuvo por efecto "un rápido desarrollo cultural" (Rosenberg, 1987, p. 16). Leiden no sólo era un centro industrial (especializado en tela), sino que poseía una de las universidades más prestigiosas y afamadas de la época.

Sus padres eran lo que se pueden considerar burgueses acomodados o, al menos, con un buen pasar económico. Por un lado su padre, Harmen Gerritszoom, poseía un molino en las puertas de la ciudad cercano al viejo río Rhin. Por otro lado su madre, Cornelia van Suydtbroeck, descendía de una familia del patriciado urbano. Estas condiciones familiares posibilitaron que Rembrandt fuera el único de los nueve hijos que accedió a una notable educación.

En efecto, a los siete años fue enviado a la Escuela Latina (Rosenberg, 1987, p. 20) donde se instruyó en el latín (a través de la lectura de los clásicos como Cicerón o Virgilio) y el griego. En las clases de religión estudió la Biblia y aprendió la doctrina calvinista.

Así, en el próspero y pujante ambiente de la burguesía holandesa crecería el joven Rembrandt. Recordemos que Holanda junto con Inglaterra fueron las potencias que menos sintieron los efectos de la recesión económica que se produjo a fines del siglo XVI, causada básicamente por la poca disponibilidad de metales preciosos, la baja de precios y la reducción de intercambios comerciales. Esta situación tuvo como efecto la decadencia de las potencias ibéricas; en cambio, Holanda e Inglaterra comenzaron su camino hacia la hegemonía comercial mundial.

Este contexto económico de progreso, que se cristalizó definitivamente en el siglo XVIII y XIX con los logros políticos de la burguesía, ayudó a configurar los nuevos elementos que Rembrandt traería al terreno artístico. Esto es, que las nuevas representaciones que se daban en el terreno de la pintura y el dibujo fueron posibles, en parte, gracias a las concepciones más liberales que traía la burguesía respecto de la limitada Edad Media.

Pero si bien en lo profesional Rembrandt se había convertido en toda una celebridad y había creado su propia escuela artística, cuyos alumnos reproducían fielmente el estilo del maestro, en lo personal su vida era por completo desdichada.

El artista contrajo matrimonio con Saskia van Uylengurgh en 1634, joven perteneciente a las prósperas clases acomodadas. Esto permitió a Rembrandt ascender en la escala social y afianzar más su fama de pintor. Pero a la felicidad del comienzo de la relación le siguió 
la tragedia, ya que de los cuatro hijos que tuvo con Saskia sólo el último, Titus, sobrevivió a la infancia. Luego vinieron dos niñas en 1638 y 1640, ambas llamadas Cornelia, que no sobrevivieron más de un mes. Dos años más tarde en 1642, moría en Ámsterdam la propia Saskia ${ }^{2}$.

En cuanto a lo estrictamente artístico, Rembrandt es, en primer lugar, uno de los maestros del claroscuro, estilo impulsado por Caravaggio en el barroco temprano (Rosenberg, 1987 p. 308) que juega con las luces y las sombras para tratar de conseguir ciertos efectos dramáticos e inquietantes en sus pinturas y dibujos.

En segundo término, lo podemos ubicar como uno de los representantes del barroco centroeuropeo en donde se destacará, entre otras cosas, un carácter mercantil de lo artístico. Pero en contraposición al barroco cortesano, más ligado a los intereses del catolicismo romano, Rembrandt desarrollará en Holanda "un barroco más carnal" (Aulicino, 2006, párr. 4) y sobre todo, realista. Aunque el estilo de algunas de sus obras no coincidían del todo con el gusto burgués. Así es como, en ocasiones, su "naturalismo extraño era rechazado" (Aulicino, 2006, párr. 9) porque los ricos burgueses no querían ser retratados en una atmósfera enrarecida.

En tercer lugar, Rembrandt fue uno de los que más trabajó sobre el retrato de grupo, generalmente encargado por cofradías de profesionales o gremios, como sería el caso de las lecciones de anatomía que se verán más adelante. En estos retratos colectivos pintaba a un gran grupo, de parecida edad y vestido, colocados en filas para que todos puedan verse retratados puesto que compartían los gastos ${ }^{3}$.

\section{Cuerpos Medievales y Modernos}

Ahora bien, una vez situado el personaje en la dimensión histórica y estética, es pertinente ver qué concepción de la corporalidad imperaba hasta la ruptura que impuso la Modernidad y que podemos ver representada por medio de artistas de la talla de Rembrandt o Caravaggio. Ruptura que se va a manifestar en el lento pero inexorable desgarramiento del tejido social que había constituido la Edad Media.

En este sentido, hubo un tiempo en que el cuerpo era la viva expresión del pueblo. Mejor dicho, el cuerpo era inseparable de la comunidad, del mundo, del cosmos. Sin límites hacia el otro y desenfrenado en sus funciones orgánicas. El cuerpo grotesco -nos dice Le Breton citando a Mijail Bajtín- es uno abierto al mundo, es decir: "en los orificios, en las protuberancias, en todas las ramificaciones y excrecencias" (Le Breton, 2002 p. 31). Este cuerpo, que Bajtín denomina "grotesco" y que en este trabajo podemos nominar como medieval o cuerpo comunitario, "no tiene una demarcación respecto del mundo, no está encerrado, terminado ni listo, sino que se excede a sí mismo, atraviesa sus propios límites" (Le Breton, 2002 , p. 31). Todavía no estaba definido, recortado, por una matriz social constrictiva.

Este cuerpo comunitario o integrado al mundo tenía su máxima expresión en el carnaval medieval, en donde el pueblo daba rienda suelta al desparpajo en oposición a la seriedad y sobriedad impuesta por la estructura eclesiástica que colonizaba todos los ámbitos de la vida. En efecto, "en el júbilo del carnaval, por ejemplo, los cuerpos se entremezclaban sin distinciones, participan de un estado común: el de la comunidad llevado a la incandes- 
cencia" (Le Breton, 2002 p. 30). En este marco festivo era impensable una separación, en el sentido de espectáculo, todos eran parte del escenario, todos participaban, nadie miraba. Pero este tipo de prácticas sociales, que se pueden reconstruir a través de obras como la de Rabelais, hay que insertarlas en un contexto social determinado.

Primero, como se dijo, hay que pensar en un mundo dominado espiritualmente por la estructura que despliega la Iglesia Cristiana en toda la Europa Occidental, convirtiéndose en la cultura oficial de la época. En consecuencia, en segundo lugar, el cuerpo humano era -junto con todos los bienes que habitaban la existencia- una creación de Dios; lo cual le aseguraba al cuerpo un destino que sólo podía ser manipulado por la Iglesia. En tercer lugar, todavía se concebía al mundo con restos del viejo animismo. En este enfoque, la vida lo inundaba todo, ya que todavía "no se había descubierta (la) mera materia, es decir, realmente inanimada, muerta" (Jonas, 2000 p. 21). En contraposición a la Modernidad (objetivante), para el hombre anterior a la Ilustración la vida era la regla del universo y "la muerte es el enigma que mira fijamente a los ojos al hombre y contradice ese fenómeno comprendido, autoexplicativo, natural, que es la vida universal" (Jonas, 2000 p. 22).

Así, se puede apreciar como un tejido social como el medieval no pudo haber producido una mirada instrumental y calculante sobre el cuerpo como la que representará Rembrandt en el siglo XVII. Fundamentalmente, porque no pudo separar al cuerpo humano del mundo circundante, porque no pudo convertirlo en res; en definitiva, re-ificarlo o cosificarlo para transformarlo en un mero instrumento. Claro que, para que surgiera una visión semejante, debía entrar en juego en la escena social una nueva clase social con nuevos intereses y prácticas sociales.

Con el establecimiento de la burguesía y del Capitalismo como modo de producción dominante, se despliega un novedoso proceso civilizatorio que tendría como efecto retraer la corporalidad en sus funciones orgánicas, que lo limitaría como una frontera, pero pondría toda su atención en la psicología y en las buenas costumbres pero también en su disciplinamiento. Así, el cuerpo era algo que había que reprimir y contener. Según Nobert Elías, cuando el hombre deja de estar solo y crecen sus relaciones sociales, su interdependencia con los demás, "se ve obligado a organizar su comportamiento de modo cada vez más diferenciado, más regular y más estable" (Elías, 1994 p. 451). En este sentido, la corporalidad se comienza a mostrar como algo que había que dominar y ciertas reacciones empezaron a ser consideradas como irracionales o incivilizadas. Las pasiones retrocedieron ante la mirada de los otros que lo comenzaron a condicionar. A su vez, una parte importante del aplacamiento de los instintos es activada por el individuo inconscientemente. Elías denomina autocoacción a este mecanismo de control, cuya función es la regulación permanente que se le inculca al individuo desde que nace.

\section{Amanecer de una nueva estética}

“...el arte es, dentro de la cultura afirmativa, el ámbito supremo y más representativo de la cultura". (H. Marcuse, Cultura y sociedad) 
Se pasó, entonces, de un cuerpo abierto al mundo a uno cerrado sobre sí mismo. Pero en realidad, ¿qué significa esto? O mejor dicho: ¿qué relevancia puede tener este hecho a los efectos de un trabajo como el que aquí se propone?

Lo que se intenta mostrar es cómo una incipiente época (la burguesa) va a construir ciertas representaciones y uno de los que va a cristalizar estos nuevos signos no es otro que el viejo Rembrandt. El artista holandés parece convertirse en un punto en la historia del arte en donde los restos de la Edad Media buscan sobrevivir entre las nuevas "cosas del mundo" que mueven a los hombres a realizar su trabajo. Como fuente de inspiración, los motivos religiosos dan paso a los deseos propios de los individuos que quieren verse retratados, así como las nuevas profesiones y prácticas sociales.

En otras palabras, la nueva matriz social construye una estética que le es propia y que va a coincidir con las necesidades y usos de un sujeto capitalista que iba a transformar al mundo de una forma nunca antes vista. Esto va a traer como efecto que la estética "sacra" y de inspiración exclusivamente bíblica va a ir quedando relegada, puesto que el centro de la escena va a ser ocupado por el ser humano. Pero este fenómeno no va a ser exclusivo de la pintura, sino que se va a dar en otros ámbitos como en el pensamiento filosófico, por ejemplo en autores renacentistas como Tomás Moro, o en pensadores políticos como Nicolás Maquiavelo.

Estas necesidades y usos tienen que ver con que, como ya se ha sugerido, Dios y la Iglesia ya no van a constituir el centro de la vida social. Es en ese punto que las nuevas formas de socialización harán que el individuo desee verse representado en las distintas formas plásticas. Ya no es la comunidad, sino el individuo recortado y toda su geografía la que comienza a representarse. En efecto, la boca, "órgano de la avidez del contacto con los otros por medio del habla, del grito o del canto", del exceso, de la bebida y de la comida (Le Breton, 2002, p. 41), deja su lugar de privilegio al aspecto más psicológico de los retratados: la mirada. En definitiva, lo que sucede es que "la axiología corporal se modifica. Los ojos son los órganos que se benefician" con la emergencia de la nueva cultura del individuo (Le Breton, 2002, p. 30). En el caso de Rembrandt esta importancia de la mirada en general, y de los ojos en particular, se torna curiosa: si se observa detenidamente distintas obras del artista todos los ojos que tienen los personajes son los mismos. Desde Saskia, su mujer, en un retrato (Retrato de Saskia con sombrero, óleo sobre tabla, 1633) hasta la figura de Abraham en una representación de una escena bíblica (El sacrificio de Isaac, óleo sobre lienzo, 1635). Pero tampoco escapan a este rasgo particular los retratos colectivos ni los propios autorretratos de Rembrandt.

En este sentido, el de Rembrandt es un caso paradigmático, pues la realización de autorretratos recorre una parte importante de su obra. Lo que nos muestra la importancia que había adquirido como valor la propia representación, como parte del ejercicio artístico, pero también como muestra de una nueva sensibilidad singular. Es así como se ha señalado que su gran producción de autorretratos ${ }^{4}$ no es sino "su conciencia de individuo único e irrepetible y su inexorable caminar hacia la muerte" (Parrondo, 2005, p. 11). Por tanto, la visión cristiana del "más allá" y de la promesa de otra vida se quiebra por completo. El artista en general no pinta y se pinta porque tiene un lugar asegurado junto al creador, sino justamente por lo opuesto: al no tener una existencia asegurada y experimentar como hombres de carne y hueso "el sentimiento trágico de la vida" (Unamuno, 1993, p. 23) y, por 
eso mismo, lo absurdo de la existencia como diría Albert Camus ${ }^{5}$, eso es lo que lo motiva a realizar la obra. "Uno pinta y escribe porque se sabe finito, mortal y no por otra cosa". Si la existencia fuese algo completo, el arte no tendría sentido. Para qué intentar trascender si tengo la eternidad por delante.

Sin embargo, en el primer período de autorretratos de Rembrandt, lo que predomina es sobre todo una búsqueda técnica centrada en la expresión y la fisonomía, en donde no importa los temas sino el claroscuro y los estados de ánimo. Por ejemplo, el primer autorretrato que se le conoce es Autorretrato con pelo enmarañado (Óleo sobre tabla, hacia 1628), en donde la atención no está puesta tanto en su persona sino más bien en un ejercicio plástico que tiene que ver con el estudio "de la incidencia de la luz sobre un rostro visto como de improviso" (Parrondo, 2005, p. 29).

En el período de Leiden, en cambio, los temas comienzan a tomar una relevancia mayor. Por ejemplo, El pintor en su estudio (Óleo sobre tabla, 1629) se lo interpreta como un cuadro en donde Rembrandt simboliza su punto de vista sobre el trabajo constante del artista. También, apelando a retratos de artistas célebres que se hacían en el siglo XVI, Rembrandt aparece en numerosos autorretratos disfrazados o con trajes históricos (vestido de soldado o con traje de burgués o como un noble oriental).

Hacia los últimos períodos de su carrera, como en Autorretrato con bastón (Óleo sobre lienzo, 1658) y Autorretrato con paleta y pinceles (Óleo sobre lienzo, 1665), Rembrandt muestra una gran conciencia de su existencia al representar el paso del tiempo de su propio cuerpo, ahora cansado, pero también con cierto aire melancólico. Esto lo vemos en particular en la "sombra que vela la mirada del artista" (Parrondo, 2005 p. 144).

Por último, podemos concluir en este apartado que Rembrandt aparece como muestra de lo que estaba sucediendo históricamente con las representaciones que el hombre se encargaba de crear. En efecto, "el individuo deja de ser el miembro inseparable de la comunidad, del gran cuerpo social, y se vuelve un cuerpo para él solo" (Le Breton, 2002, p. 43). El hombre aislado, recortado del tejido social, es lo que toma fuerza en esta época y tiene su primer centro en el rostro del hombre, que se convierte en la marca clave de su singularidad. Es por eso que a partir del siglo XV, el retrato como forma pictórica en Europa se afianza en el arte. Así, al no tener un anclaje religioso, la obra de arte se vuelve "una celebración personal sin ninguna otra justificación" (Le Breton, 2002, p. 42).

Desde este punto de vista, "el arte por el arte por el arte" se hace posible, puesto que su derecho a existir ya no giraría en torno a Dios y sus administradores terrenales. Es por eso que, como bien lo dice Adorno, "tras haber sacudido su función cultual, (...) la autonomía exigida por el arte se alimentó de la idea de humanidad" (Adorno, 1983, p. 9).

\section{Liberación y sujeción}

"La sociedad burguesa liberó a los individuos, pero sólo en tanto personas que han de mantenerse disciplinadas"

(H. Marcuse, Cultura y sociedad). 
Pero no hay que engañarse: la autonomía (del arte) aquí no es sinónimo de liberación. Así lo confirma Adorno cuando dice que, si bien se alimenta de la idea de humanidad, esta misma idea se desmorona "en la medida en que la sociedad se fue haciendo menos humana" (Adorno, 1983 p. 9). Dicho de otro modo, el arte consigue una liberación del encierro eclesiástico, pero sólo para caer en las invisibles manos del mercado de bienes. $\mathrm{Al}$ mismo tiempo, va a ir construyendo una autonomía -como le sucede al sujeto humanode la propia comunidad que lo produce; la extensa marcha del realismo hasta lo abstracto, puesto que el divorcio con las cosas de la sociedad se va a dar fuertemente en el terreno de la referencialidad. Se abandona esa obligación de "reflejar" y estar atado al mundo para dar paso a la pura expresión del artista.

Volvamos a Rembrandt y a la corporalidad.

Una vez librado del marco cultural y cultual que dictaba la Iglesia, el arte comenzó a desplegar toda una serie de nuevas representaciones. Como se observó antes, las figuras bíblicas van dejando su lugar al sujeto (individual) que arriba con la Modernidad y el capitalismo. El arte vira hacia lo humano. Aunque se puede preguntar: ¿el arte vira hacia lo humano o es que ocurre ese movimiento contradictorio que afirmaba Adorno: liberación de la función cultual y entrada en una fase de deshumanización de la sociedad? ¿Acaso no era humana la representación con motivos religiosos?

Lo que ocurre en esta operación, en este movimiento histórico del arte es, en definitiva, una sujeción: el cuerpo de los seres humanos es capturado por las representaciones del nuevo arte burgués. Captura, ¿por qué ocurre tal operación simbólica en los albores de la Modernidad? ¿Por qué se da en ese momento y no en otro? Trasladado a la dimensión "Rembrandt", que es lo que aquí importa, se puede preguntar lo siguiente: entonces, ¿qué significa exactamente la pintura La lección de anatomía del doctor Tulp en el contexto de una reflexión como ésta?

Recorramos primero La lección de anatomía del doctor Tulp (óleo sobre lienzo, 1632), que es encargada a Rembrandt por miembros del gremio de cirujanos "que querían hacerse retratar en grupo en el contexto de una clase de anatomía" (Parrondo, 2005, p. 35). La pintura nos muestra una estética realista y racionalista en una escena donde vemos a los aprendices atentos a la operación que el doctor Nicolás Tulp, profesor de anatomía del gremio de cirujanos entre 1628 y 1653, realiza sobre un cuerpo inerme y, ahora, al servicio de las luces de la Ilustración que asomaban por esos años en toda Europa.

Pero el cuerpo sometido al ojo clínico no es un cuerpo cualquiera. Adriaan Adrianszoon, conocido como Aris Kint, no era un burgués ni un artesano, sino un vulgar ladrón. La sujeción y el estudio quirúrgico del cuerpo unen sus fuerzas y, como no podía ser de otra manera, comienzan sus indagaciones por los "descartes sociales" ${ }^{\text {. }}$ Pero esto no es una casualidad, y se lo ha interpretado de la siguiente manera: "La escena de la disección es, pues, ejercicio de jurisdicción sobre el cuerpo de Aris Kindt, acto de dominación penal y soberana que al mismo tiempo resulta ejemplar y sustantivo, simbólico y material" (Barker, 1984, p. 95).

La nueva forma cultural muestra las uñas. Los cuerpos ya no tendrán derecho a la trascendencia ni a poder descansar en paz. El cuerpo se convertirá en objeto del más extraordinario dispositivo sin el cual es imposible pensar la Modernidad: el Estado-Nación. Ya sea en el ejército, en los hospitales o las cárceles el cuerpo será un blanco susceptible de ser 
controlado, marcado, estudiado, medido, curado. En definitiva, lo que se buscaba era la docilización del cuerpo ${ }^{7}$.

Pero este sometimiento no es gratuito, puesto que ahora el cuerpo estará inmerso en un "campo político": "las relaciones de poder operan sobre él una presa inmediata; lo cercan, lo marcan, lo doman, lo someten a suplicio, lo fuerzan a unos trabajos, lo obligan a unas ceremonias, exigen de él unos signos" (Foucault, 1987, p. 32). Eso mismo le sucede a Aris Kindt, las prácticas del doctor Tulp, y del mismo Rembrandt en otro aspecto, lo someten a constituir un medio para el avance de la moderna medicina, pero, a su vez, lo obligan a significar (por última vez) bajo un "régimen de sujeción que se empieza a practicar en esta pintura" (Barker, 1984, p. 94).

La ley y la ciencia, aún muerto Aris Kindt, no lo deja tranquilo. Por eso es que la obra no celebra su cuerpo, sino el acto de conocimiento que desarrolla Tulp a su alrededor y delante de sus aprendices. Así, es como el cuadro va a representar no una anécdota histórica (la disección pública de cadáveres tan practicada por aquellos años, que era seguida por una comida), sino un "episodio cargado con la semiosis del nuevo poder" (Barker, 1984, p. 94). Y, al fin y al cabo, no asistimos a otra cosa que a la representación que una clase social realiza sobre sí misma.

Cabe agregar que, a la mirada quirúrgica y burguesa sobre la corporalidad, se estaba sumando también en tierras holandesas la mirada filosófica bajo la pluma del padre del racionalismo: René Descartes ${ }^{8}$; quien inscribe en lo corporal todos los errores e infortunios del hombre, puesto que él es -como declara en sus Meditaciones Metafísicas-primero una "cosa que piensa" más que una res extensa. Con esta visión filosófica por detrás, se deja el camino libre para hacer del cuerpo, antes que nada, una máquina para el trabajo.

Nace, entonces, una corporalidad más ligada a una sujeción que a una liberación. Porque, como ya sabemos, no hay tal libertad (absoluta) sino en formas de infinitas de alienación?

\section{La otra lección de anatomía}

La otra referencia importante que encontramos respecto de la nueva corporalidad que se estaba construyendo en las representaciones pictóricas de Rembrandt, es La lección de anatomía del doctor Deyman (óleo sobre lienzo, 1656). Pero esta obra no alcanzó la fama de La lección de anatomía del doctor Tulp. Quizás, porque un incendio destruyó parte importante del lienzo en 1723, del cual se conserva el fragmento de la parte central de la zona inferior del cuadro. Allí sólo podemos observar a Gysbrecht Calcoen, maestro del gremio de cirujanos, participando de la disección de un cadáver con la calota ${ }^{10}$ en su mano izquierda. Pero del protagonista de la pintura, el doctor Jay Deyman, sólo se puede apreciar el pecho y las manos operando sobre el cerebro del muerto, ya que su cabeza fue víctima del incendio mencionado.

Se ha señalado que lo interesante y original de esta obra es la posición del cuerpo diseccionado: se encuentra de frente a la mirada del espectador. También se lo ha visto como una cita al Cristo muerto de Andrea Magenta (Parrondo, 2005). Pero para los ojos de los habitantes del siglo XXI, esa imagen del cuerpo muerto que interpela de frente al observador no puede ser otra que la del cadáver de Ernesto "Che" Guevara. Claro que, la imagen de 
Guevara muerto en Bolivia, está rodeada para nuestra mirada cultural con los signos del arrojo y la revolución social de épocas pasadas. En el caso de la pintura de Rembrandt, lo que rodea al cuerpo es la mirada científica y de progreso de los inicios de la Modernidad.

\section{La imposibilidad}

Lejos del siglo XVII que nos trae Rembrandt con su excepcional obra, la corporalidad y la estética en la actualidad constituyen temas centrales de nuestras sociedades occidentales. Con la pérdida del Estado-Nación como articulador de nuestras vidas y, junto con esto, la destitución de los conceptos de Verdad, Progreso y Razón, los temas en el campo teórico viran hacia temas como el cuerpo y la sexualidad, la administración de la bios (la biopolítica). Cuando la Identidad no puede anclarse en ideas e ideales trascendentes (que ya no hacen ningún sentido), cuando el peligro de la disolución y de la dispersión total de las subjetividades se convierte en un signo epocal, cuando todo esto se condensa, el Cuerpo y su cuidado y su estética se convierten en el centro de nuestras vidas. En palabras de Terry Eagleton: "El sujeto posmoderno, a diferencia de su antecesor cartesiano, es uno cuyo cuerpo está integrado a su identidad" (Eagleton, 1998 p. 109). Somos el cuerpo que representamos en nuestros avatares sociales. Es decir, al derrumbarse todo a su alrededor, el sujeto contemporáneo queda desamparado y sin referencias fijas y fuertes a las que remitirse. A lo único que puede recurrir es a la inmediatez de su cuerpo, con la ilusión de poder controlar algo en un mundo tan fragmentado.

Pero la cuestión es que las representaciones estéticas del cuerpo construidas en la actualidad tienen su centro en un discurso publicitario y cuya gramática se fluidiza y transforma en las redes sociales. La liberación y la exhibición de los cuerpos no es total, ya que "si el cuerpo libidinal sirve, el trabajador, no" (Eagleton, 1998, p. 112). El eje de las representaciones parece desplazarse políticamente de la producción al placer: "Hay cuerpos mutilados en abundancia, pero pocos desnutridos" (Eagleton, 1998, p. 112). Hay una corporalidad liviana que acompaña la estética de esta era de vacío.

Ahora bien, la obra de Rembrandt nos sirve para comprender no tanto la larga marcha que ha sufrido el cuerpo como representación desde la lejana Edad Media hasta el ocaso de la Postmodernidad, sino cómo fueron los comienzos de una concepción de la corporalidad. También el artista holandés sirve de muestra para observar una etapa clave de la historia de la subjetividad: el momento en que el hombre empieza a tomarse a él mismo como tema y referencia ${ }^{11}$.

El arte de Rembrandt, entonces, parece operar como signo del cambio que estaba sucediendo con la existencia del hombre. Pero también -como veíamos en los sucesivos autorretratos del pintor- como conciencia del propio devenir del ser humano, en esa "carrera que nos precipita un poco más hacia la muerte" y en la que "el cuerpo mantiene una delantera irreparable" (Camus, 2004, p. 16). Conciencia (exasperada) que prevalece en una época como la nuestra tan empeñada (por medio de la tecnología, de la techné) en preservar del paso del tiempo lo imposible: el cuerpo propio. 


\section{Notas}

1. Literalmente: "junto al Rhin".

2. Cabe mencionar también, luego de la muerte de Saskia, las penurias económicas sufridas por el artista (entra en bancarrota) y los "escándalos morales" que lo envolvieron por el desarrollo de su vida privada.

3. En diversas ocasiones, luego de ver la obra terminada, los que pagaban por las pinturas le reclamaban al artista por ciertos detalles o por el hecho de no aparecer protagonizando la composición.

4. Exactamente se pueden contabilizar el siguiente número de autorretratos: 30 pinturas, 26 aguafuertes y 12 dibujos.

5. Dice Camus: "por una parte, lo absurdo enseña que todas las experiencias son indiferentes y, por la otra, impulsa a la mayor cantidad de experiencias" (Camus, 2004, p. 69). Una de esas experiencias, la constituye el Arte, como expresión contradictoria del ser de lo humano.

6. Recordemos que recién en esta época se comienzan a hacer disecciones de cadáveres permitidas. Años atrás estas prácticas sólo se realizaban en forma clandestina

7. Aquí, con Michel Foucault, entendemos por dócil a "un cuerpo que puede ser sometido, que puede ser utilizado, que puede ser transformado y perfeccionado" (Foucault, 1987, p 140).

8. Recordemos que cuatro años antes (1628) de que Rembrandt pintara la lección de anatomía Descartes se trasladaba a Holanda en busca de "soledad y libertad para crear" (Descartes, 2004).

9. Como alienación no entendemos algo puramente negativo, sino en el sentido ontológico como un estado del hombre. En términos fenomenológicos: no hay un sujeto con una intencionalidad vacía, sino que siempre se está intencionando algo.

10. Según el diccionario enciclopédico Larousse (Tomo II, 1983, p. 428) "Parte superior de la bóveda craneal".

11. Hoy vemos el punto culmine de este proceso en el llamado "arte confesional", en el cual se exhibe la propia intimidad con diferentes matices. Por un lado, Tracey Emin utilizó como temas su violación, sus dos abortos y el tamaño del pene de su novio entre otras cosas. Por otro lado, el argentino Guillermo Iuso hizo de su obra un registro autobiográfico como si uno leyera viejos cuadernos de apuntes escritos con Silvapen.

\section{Bibliografía}

Adorno, T. (1983). Teoría estética, Madrid: Orbis.

Aulicino, J., "Un genio de luz y sombra” en Revista ñ, número 133 del sábado 14 de abril de 2006. Recuperado de: http://edant.clarin.com/suplementos/cultura/2006/04/15/u-01176154.htm Barker, F. S. (1984). Cuerpo y temblor. Un ensayo sobre la sujeción. Buenos Aires: Edit. Per Abbat.

Camus, A. (2004). El mito de Sísifo. Buenos Aires: Editorial Losada S. A.

Eagleton, T. (1998). Las ilusiones del posmodernismo. Buenos Aires: Paidos. 
Elías, N. (1994). El proceso de la civilización. México: Fondo de Cultura Económica. Foucault, M. (1987). Vigilar y Castigar, el nacimiento de la prisión. Buenos Aires: Siglo XXI. Grüner, E. El sitio de la mirada.

Jonas, H. (2000). El principio vida. Valladolid: Trotta.

Le Breton, D. (2002). Antropología del cuerpo y modernidad. Buenos Aires: Editorial Nueva Visión.

Parrondo, J. C. (2005). “Rembrandt. Sabiduría y emoción” en Los grandes genios del arte, Tomo número 11, Rembrandt, Biblioteca del diario El Mundo de España, Unidad Editorial S. A.

Rosenberg, J. (1987). Rembrandt. Vida y obra. Madrid: Alianza.

Unamuno, M. (1993). Del sentimiento trágico de la vida. España: Editorial Planeta - De Agostini.

\begin{abstract}
The production and context of the Dutch painter Rembrandt Harmenszoon van Rijn, allows an analysis of various changes in the conceptions of subjectivity and body that occur in the European world at the beginning of the 17th century. Through the so-called anatomy lessons and his self-portraits, Rembrandt gives an account of rationalization, the appearance of the individual and objectification of corporality; from a body united to the community in the Middle Ages, to the representation in the Modernity of a body as an inert object; from the community subject to the perception of the subject as a unit.
\end{abstract}

Keywords: subjectivity - Rembrandt - Harmenszoon van Rijn - 1606-1669 - art - Baroque mod.

Resumo: A produção e o contexto do pintor holandês Rembrandt Harmenszoon van Rijn, permite uma análise de várias mudanças nas concepções de subjetividade e do corpo que ocorrem no mundo europeu no início do século XVII. Através do chamadas de lições de anatomia e seus auto-retratos, Rembrandt dá conta da racionalização, a aparência do indivíduo e a objetivação da corporeidade: de um corpo unido à comunidade na a Idade Média, à representação na Modernidade de um corpo como um objeto inerte da comunidade sujeito à percepção do sujeito como uma unidade.

Palavras chave: Subjetividade - Rembrandt - Harmenszoon van Rijn - 1606-1669 - arte barroco - modernidade - estética.

[Las traducciones de los abstracts fueron supervisadas por el autor de cada artículo] 

Fecha de recepción: abril 2019

Fecha de aceptación: octubre 2019

Versión final: marzo 2020
Nostalgia Cinematográfica

Laura Mastantuono *

Resumen: Globalmente las esferas sociales y culturales atraviesan una crisis que involucra una multiplicidad de variables. Ante la inestabilidad social, y la modificación continua de las herramientas para la producción de contenidos de las diversas áreas culturales, se observa una mirada nostálgica sobre la realización y cierta tendencia al revisionismo histórico. En el diseño y comunicación audiovisual, la inestabilidad discursiva y formal dan lugar a una búsqueda artística hacia lo analógico y estudios sobre la importancia del archivo audiovisual y el found footage; axiomáticamente se entiende éste criterio como un accionar seguro sobre lo conocido, y un intento de comprender de manera objetiva el pasado.

Palabras clave: Comunicación audiovisual - diseño de imagen y sonido - cinematografía analógica - fílmico - digital - revisionismo - cultura - discurso y forma - found footage archivos - restauración - herramientas audiovisuales.

[Resúmenes en inglés y portugués en las páginas 150-151]

(*) Licenciada en Comunicación Audiovisual (Universidad de Palermo) Trabaja de manera independiente en el área de realización audiovisual, ha sido parte de largometrajes y cortometrajes documentales y ficcionales en Argentina, Colombia y España. Los proyectos han sido seleccionados en festivales alrededor del mundo, entre ellos el Festival de Cannes. Colabora en producciones de comunicación institucional para empresas digitales, y se desempeñó como gerente de contenido y edición. Dentro del área de investigación escribe para diversos medios online en inglés y español, y trabajó, dentro de un programa de voluntariado, en el Museo del Cine de Buenos Aires, restaurando y catalogando el archivo de nitrato y acetato. Desde el año 2014 forma parte del equipo docente de la Universidad de Palermo.

\section{Paradojas de la cultura posmoderna}

De acuerdo con su concepto original, la "cultura" no debía ser una preservación del status quo sino un agente de cambio; más precisamente, un instrumento de navegación para guiar la evolución social hacia una condición humana universal. El propósito original del concepto de "cultura" no era servir como un registro de descripciones, inventarios y codificaciones de la situación imperante, sino más bien fijar una meta y una dirección para las iniciativas futuras. El nombre "cultura" fue asignado a una misión proselitista que se había 
planeado y emprendido como una serie de tentativas cuyo objeto era educar a las masas y refinar sus costumbres, para mejorar así la sociedad y conducir al "pueblo"-es decir, a quienes provenían de las "profundidades de la sociedad"hacia sus más altas cumbres (Bauman, 2013, p. 14).

Previo al siglo XX se entendía la cultura y educación cómo una parte inherente de las responsabilidades del Estado - Nación, la ilustración de la, entonces, considerada barbarie. Con el inicio de las revoluciones, de las grandes guerras y la industrialización, rápidamente el concepto de cultura se vuelca hacia su propia antítesis. Comienza con todas sus dualidades un siglo de rupturas. "En resumen, la 'cultura' dejaba de ser un estimulante para transformarse en tranquilizante, dejaba de ser el arsenal de una revolución moderna para transformarse en un depósito de productos conservantes" (Bauman, 2013, p. 16). Las esferas culturales se inclinaban a colaborar con el mantenimiento del sistema que estaba ante su fin, y daría lugar a lo que hoy se entiende como posmodernidad y su multiplicidad de paradigmas como característica. Ante este nuevo modelo la cultura deja de ser prohibitiva y/o separatista para dar lugar a un abanico de posibilidades y propuestas. La cultura forma parte del mercado y su oferta cambia constantemente al ritmo de las tendencias, modas y evolución de las diversas herramientas de producción y consumo. Lo posmoderno se caracteriza por la saturación, el auge de la información, la sociedad del consumo y comunicación masiva. Cierta apatía generalizada, una oda al individualismo, a lo efímero; la integración de un pluralismo de miradas como consecuencia de la modernización ilimitada y continúa. Surge cierta brecha en el pensamiento contemporáneo sobre las cualidades del arte y el entretenimiento desde una visión paradójica y crítica. La posmodernidad se encuentra atravesada y definida por la globalización y la disgregación de los límites. Sin embargo, en la segunda década del siglo XXI, se vuelcan hacia conceptos antiguos al mismo tiempo que otra parte de la sociedad lucha con erradicarlos. Dejando de lado un análisis político sobre la inestabilidad de la vida cotidiana, dada por un mundo en transición y una economía recesiva y fluctuante; no se puede ignorar el impacto y las preocupaciones generales sobre las presidencias de ideologías tradicionalistas, la incrementación del nacionalismo, la separación y conflicto dentro y entre Estados potencia, la crisis ambiental y agotamiento de recursos. Ante este cambio constante y la oferta desmedida, parecería que el ser humano intenta volver a lo conocido. En la posmodernidad contemporánea la negación del pasado, característico de la modernidad, se vuelve obsoleto. Se reciclan conceptos.

La modernidad de la que salimos era negadora, la supermodernidad es integradora. Ya no hay destrucción del pasado, sino su reintegración, su replanteamiento, en el marco de las lógicas modernas del mercado, el consumo y la individualidad. (...)

Cuántos trastornos invitan a examinar un poco más de cerca el régimen del tiempo social que gobierna la época. El pasado reaparece. Las inquietudes del porvenir reemplazan a la mística del progreso. El presente adquiere una importancia creciente por efecto del desarrollo de los mercados financieros, de las técnicas electrónicas de la información, de las costumbres individualistas y del tiempo libre (Lipovetsky, 2006, p. 61). 
La muerte del cine se vaticinó demasiadas veces, sus transformaciones con el sonido y el technicolor, el advenimiento de la televisión, la aparición del video, la tradición de ver cine traspasada al interior de los hogares. El cine digital. No sólo los cambios en el medio, la evolución formal y discursiva, sino también la diversificación del consumo, creó una incertidumbre, que tanto críticos cómo la industria en sí, veían como una profecía apocalíptica. El culto de lo nuevo que traía el modernismo no dejó de lado al audiovisual. Por lo que, en aproximadamente poco más de un siglo se transformó inclusive más veces que muchas de las artes que prevalecieron desde el origen de la civilización. El audiovisual además de ser parte de la esfera de las artes también lo es del mercado del entretenimiento y de su dinámica. La oferta y demanda moldea sus productos y el contenido en la multiplicidad de pantallas existentes de la posmodernidad creó nuevas exigencias. Entretenimiento y arte, dos aristas que muchos consideran contrapuestas, atraviesan la conceptualización de la evolución del audiovisual desde la pureza del celuloide a la iconosfera de la imagen magnética y electrónica.

La bisagra que comienza en 1995 con Toy Story de Lasseter como parte de ese mandato de renovación continua del mercado, tiene un fin cuando, de manera cuasi abrupta, a principios del siglo XXI se dejan de lado las prácticas cinematográficas con celuloide y se venera el nuevo medio. La digitalización del medio y del consumo acarreó en un primer momento un abanico de posibilidades para la creación, exhibición, distribución y visualización. Fue el momento de la segunda democratización del audiovisual, considerando el primero como aquel consecuente de los formatos menores del celuloide, $16 \mathrm{~mm}, 8 \mathrm{~mm}$ y super- $8 \mathrm{y}$ la masificación de la cinta magnética, el video, en las décadas del ' 80 y '90.

El cine, de ser un medio estrella y arte mayor en el universo estético del siglo, había pasado a ocupar un lugar acaso más restringido, como máquina de conocimiento -especialmente ligado a la antropología en la misma perspectiva de Morin, quien caracterizaba a su libro precisamente como "un ensayo antropológico" - y como un arte de masas, pero en crisis, vinculado a ciertas dramáticas transformaciones del hombre contemporáneo luego de los campos de exterminio, de la bomba atómica, de la devastación masiva y la amenaza pendiente de una aniquilación definitiva para la cual, en lo técnico, ya estaban dadas las condiciones. Pero, por otra parte, el cine ya no imperaba solo en el mundo de las imágenes que aparecían en pantalla. Otras imágenes, destellando más bien modestamente desde pequeñas e inestables pantallas, multiplicaban la experiencia audiovisual de modo algo incierto, pero ya evidente (Russo, 2008, p. 27).

El Mini DV, DV y los DVD, cómo intermedio accesible a las nuevas máquinas de video digital que aparecen a finales de la primera década del nuevo milenio. La instalación en la academia y prácticas profesionales de los sensores mínimos cuyos formatos son cercanos a los del 35 milímetros. El digital sigue intentando emular al celuloide mientras la viabilidad de la herramienta en conjunto con plataformas de visualización y distribución gratuitas como Youtube, Vimeo, y aquellas pagas como, Netflix o Hulu generan una explosión de contenidos y alta aceptación de las audiencias, al mismo tiempo que empresas exitosas 
y longevas declaran su quiebra; Blockbuster, cómo tantos negocios barriales de este tipo, cierra sus puertas con la desaparición del video de alquiler, Kodak se declara en bancarrota, cerrando muchas de sus fábricas donde se producía el celuloide, marcas importantes de cámaras entran en recesión. Desde una perspectiva del mercado el audiovisual parecía haber llegado a su fin como era conocido hasta ese momento.

La posmodernidad dejó de lado las estructuras para convertir las esferas culturales y sociales en redes interconectadas, la híper-conexión de la globalización saturada, la virtualidad en su máxima expresión; que paradójicamente tiene como consecuencia una apología del individualismo, exacerbado en las redes sociales. Narcisismo y nihilismo efímero e instantáneo, una temporalidad del aquí y ahora que conviven con cierta nostalgia e incertidumbre por el devenir social. El imaginario colectivo, entonces, se viste de frases acuñadas desde la antigüedad, indicios de una práctica discursiva que, si bien se desarrolla con una mirada crítica, venera los valores del pasado y de manera apocalíptica estudia el presente. Tal vez dado por la inseguridad subyacente sobre las nuevas prácticas virtuales, no tangibles, breves y fugaces, y la característica intrínseca sobre la integración de ideologías de la posmodernidad se re ven las prácticas y modas de décadas anteriores.

\section{Re visitar el pasado}

Previo a la instalación de Instagram como una de las redes sociales más utilizadas, -con su logo de cámara instantánea, una imagen de marca clara y que comunica de que se trata la misma-comienzan a surgir movimientos que rescatan las prácticas convencionales de fotografía y cinematografía. Se intensifica, al mismo tiempo que se instalan las cámaras digitales, una vuelta a lo analógico desde una perspectiva experimental. Sin embargo, por lo menos en Argentina, desde el 2010 se puede observar que la búsqueda de cámara antiguas y celuloide se generaliza y la practica aumenta a un público no especializado. Esta re-visión de la herramienta del pasado se da a nivel mundial. La lomografía, inspirada en la cámara rusa LOMO LC - A, fue fundada en 1991 por estudiantes austríacos, continúa siendo aquella que en términos generales experimenta con los resultados de acuerdo al tipo de cámara y celuloide. Lo que empieza como una sociedad de aficionados, se transforma en un movimiento a nivel mundial que rescata las cámaras manufacturadas por la empresa rusa LOMO y comienza a crear las propias. Por ejemplo, una de sus cámaras más conocidas es la que tiene cuatro objetivos, y dispara cuatros veces seguidas, resultando en un canvas de una imagen en secuencia (Ver figura 1). Además trabajan con diferentes empresas y tipos de celuloide que destacan ciertos aspectos de la imagen analógica de acuerdo a la sensibilidad de cada uno. Desde rollos de $35 \mathrm{~mm}$ nuevos que imprimen la imagen con un aspecto invernal de acuerdo a su temperatura de color, a rollos vencidos perfectos para experimentar con la química del paso del tiempo en el material fílmico. La asociación lomográfica se dedicó, en un principio a las cámaras tradicionales de $35 \mathrm{~mm}$, si bien se fueron expandiendo a una amplia gama de productos. Posteriormente, en el año 2008 se funda otro proyecto de este estilo, pero orientado a las cámaras y material fílmico instantáneo. El Impossible Proyect nace el mismo año que Polaroid anuncia su cierre y quiebra, y lo hace como respuesta a esto. No surge solo como un rescate de aficionados, sino como 


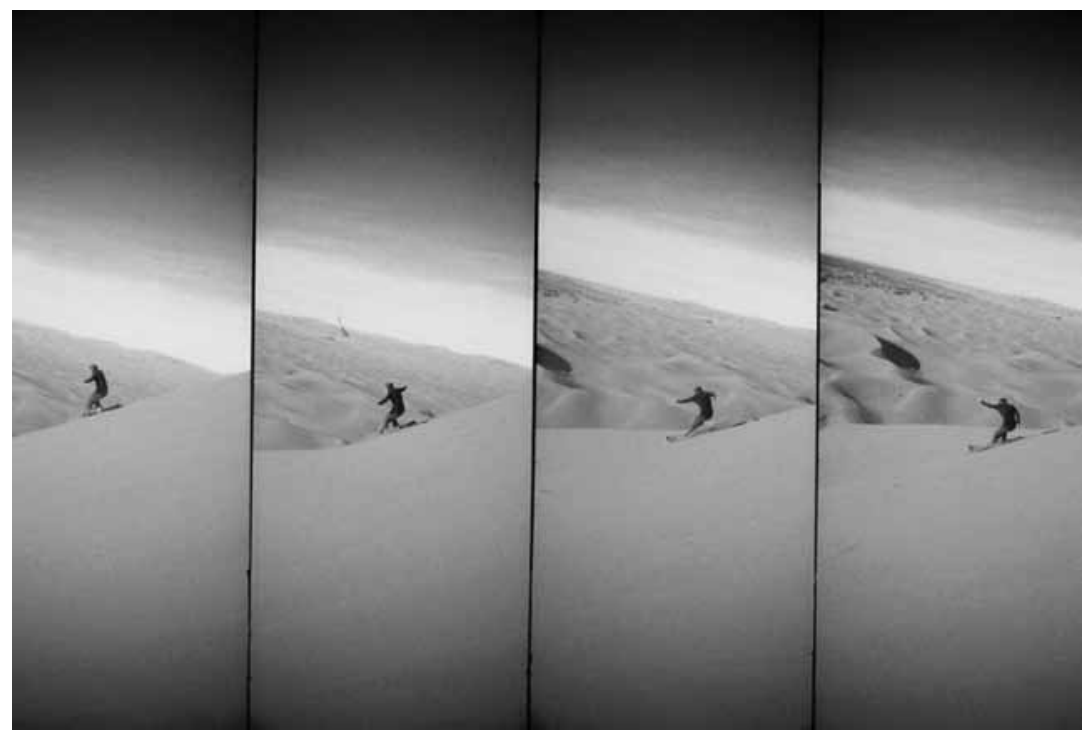

Figura 1. Imagen de la cámara supersampler. Disponible en https://shop.lomography.com/en/super sampler-rubberized-blue

un modelo de negocios. Se reabre la fábrica y se comienzan a producir cámaras y fílmico para este tipo de fotografía. Sin embargo, no es hasta el 2017 que logran tener la marca registrada y patente de la compañía original, cambiando el nombre de su proyecto por Polaroid Originals. Esta empresa respondió desde su creación a un pequeño margen del mercado, aficionado a la fotografía. Dentro de este grupo crean soluciones para cámaras antiguas, brindan un servicio técnico dejándolas listas para usar y re vender. Sin producir toda la gama de película que se hacía en un momento, creando promociones y ofertas, ofrecen una cantidad importante de opciones para volcarse a la fotografía instantánea. Este caso, resulta interesante porque no sólo han resarcido las necesidades analógicas, sino que crearon un aparato de bolsillo que funciona como un laboratorio instantáneo con formato cuadrado de polaroid para celulares inteligentes y tablets. Integraron la tecnología digital a la analógica, logrando que el público general pueda acceder a una manera de hacer tangible los momentos grabados en los celulares con un aspecto de fotografía instantánea respondiendo a las tendencias que se vuelcan a lo vintage y poseen un subtexto relacionado la calidez del pasado, la nostalgia posmoderna.

Junto a estos casos de empresas que se reintroducen en el mercado se encuentra uno de los casos más exitosos desde un punto de vista económico. El de Fujifilm. La compañía nipona se mantuvo estable creando lazos con otras empresas que satisfacían necesidades que no se vieron amenazadas por la digitalización, como Xerox, mientras que continúo manufactu- 
rando productos de fotografía instantánea. Sus ventas en esta unidad de negocios decayeron a principios de siglo, sin embargo, en el 2016 sus ganancias anuales dan cuenta sobre la creciente tendencia que se está analizando sobre la prevalencia del analógico. De acuerdo a su reporte fiscal anual el 14\% de sus ganancias provienen de la división de imagen, de los cuales el $4 \%$ es del frente digital y el $10 \%$ de los productos relacionados con la fotografía instantánea (Fujifilm Holdings Corporation, 2016). En contrapunto se encuentra el caso de Kodak, empresa que intentó sobrevivir a través de su eslogan. Previo a la digitalización los momentos solo sucedían si eran captados en fotografía y guardados para la posteridad. El famoso momento Kodak. Que luego se reinventaría en el 2010, 'el momento Kodak ocurre cuando compartes'. Las estrategias de mercadotecnia responden sin lugar a dudas a las tendencias de comportamiento del usuario y consumidor. La cultura perdió en gran medida su índole de progreso e ilustración a la que alude Bauman y dentro del concepto de modernidad líquida de este autor, no cabe duda alguna que la cultura se mercantiliza, dejando de lado una mirada inocente, de ahí se observa la integración del todo. Si existen más posibilidades de venta, de generación de productos y contenidos, mayor será la demanda. El liberalismo cultural.

No obstante, la división de fotografía de Kodak sufrió grandes pérdidas y llegó a la quiebra. Más allá de un análisis del modelo de negocio de la compañía que duró poco más de 100 años, importa su división cinematográfica. La producción de película de $35 \mathrm{~mm}$ y formatos menores.

En la actualidad Fujifilm es el único competidor de esta marca, pero la empresa norteamericana utiliza sus estrategias de comunicación abocada a la re-invención del fílmico y la elección del mismo sobre su contrapunto digital, el $4 \mathrm{~K}, 6 \mathrm{~K} \mathrm{u} 8 \mathrm{~K}$. Los grandes formatos de cinematografía digital.

Después de poco 10 años de supremacía y en cierta medida un encanto por la accesibilidad de las soluciones digitales en la industria audiovisual, la misma vuelve a su medio original. En el año 2017, de las casi 60 películas que conformaron el programa del Festival Internacional de Cannes, 15 fueron filmadas en $35 \mathrm{~mm}$ con película Kodak. (Kodak, 2017) De las 9 películas nominadas a los premios Oscar del 2018 en la terna de mejor largometraje, 4 fueron realizadas en fílmico. La nueva trilogía de Star Wars, intentando replicar la cinematografía de la trilogía original también trabajó con celuloide y objetivos antiguos, al igual que las nuevas instalación de los comics de DC, como por ejemplo La Mujer Maravilla (Jenkins, 2017). Llama la atención que en listado de productos realizados con el material fotosensible no sólo se encuentran largometrajes, pensados para ser exhibidos en la gran pantalla, sino también uno de los últimos productos de Netflix, The Cloverfield Paradox (2018). Vogue y Chanel, reconocidas marcas relacionadas con la moda, la primera una revista, la segunda diseño de prendas, perfumes y accesorios; lanzaron un video del género fashion film, Not that kind of girl (Kelly, 2017) que retrata el día de una joven en Paris. Se filmó con película kodak de $16 \mathrm{~mm}$ (Ver Figura 2) y se observa el romanticismo de París dado por la actuación de la actriz y modelo protagonista, y los colores y textura inherentes al fílmico que retratan París con una estética que remite a la Nouvelle Vague, debido a la voz en off que dialoga con la joven y devela el artificio de lo que está siendo narrado.

Se puede rastrear como causante del intento por fotografiar con una estética del pasado, en primer lugar, las emociones evocadas en el espectador, en segundo lugar, las posibili- 


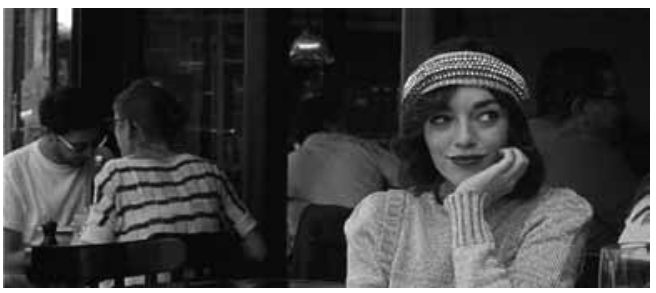

Figura 2. Fotograma del cortometraje: Not that kind of girl (Kelly, 2017).

dades técnicas propias del celuloide. Por ejemplo, la profundidad de campo lograda con esta técnica. $Y$, en tercer lugar, y posiblemente aquel que remita también a una tendencia discursiva, responde a las modas de la construcción de la imagen que se pueden observar en las redes sociales y las películas independientes. Los colores son lavados, el contraste de la imagen digital imita al del fílmico, se presenta cierta atenuación del balance de blancos. Esta se retroalimenta con los efectos proporcionados por los editores de imagen en las redes sociales, y las aplicaciones para celulares que replican las herramientas de décadas pasadas, fotos instantáneas como el caso del Instant Lab de Polaroid Originals, antes mencionado. Apps que tienen un centro de revelado y transforman la cámara del celular en una antigua automática, con los efectos propios causados en la película por la sobre exposición al sol, por nombrar uno, o aquellas que graban video imitando los efectos y sonido de una cámara de video y su reproducción en VHS.

Sobreviene una estética de la repetición desde el plano formal hacia el plano discursivo o viceversa, porque esta reincidencia o regresión a una tecnología que se creía caduca responde a cierta rebeldía sobre los avances al observar que una herramienta no suplanta a la otra. Se reitera la problemática de la integración, no solo de ideologías que se puede observar en la temática de los contenidos programados en el panorama audiovisual, sino en el cómo se realizan esos contenidos.

Un medio no reemplaza al otro, no produce el fin o la muerte como fue vaticinado, si bien por un breve lapso de tiempo pareció que lo era. Cuando la crítica y la reflexión se instala en el oficio, y se responde a las necesidades y deseos del mercado, del consumidor, la oferta arroja nuevos tipos de productos que remiten al pasado, una yuxtaposición de lo conocido con la técnica del presente cuya utilidad fue comprobable. Se desliga en parte del avance por el avance mismo. El cine traspasa los medios que lo gestaron.

El cine en un sentido amplio o expandido. Nos referimos a un medio que aparece diluido entre los nuevos medios de comunicación. Las obras audiovisuales son cada vez menos puras y en su lugar encontramos obras de carácter híbrido que exhiben la yuxtaposición mediática, esto se puede ver en imágenes fotográficas, cinematográficas, videográficas, digitales o en red; en las que es cada vez más común la desaparición de las fronteras entre géneros y estilos y la re-significación de los discursos tradicionales (entre documental y ficción, 
vanguardia y arte de masas, alta y baja tecnología, películas amateur, de arte y cine industrial, cine de atracciones - cine narrativo y la estética del clip por citar algunos ejemplos) (Noriega, 2012, p. 137).

La posmodernidad da lugar a una convivencia masiva del arte y el entretenimiento que hasta el momento había sido conceptos contrapuestos, utilizados en la experimentación y negadores el uno del otro.

\section{Re visión del pasado}

$\mathrm{Al}$ mismo tiempo que la industria del entretenimiento re visita las herramientas y discursos anteriores, componiendo contenidos totalizadores, la academia e investigación responde al material desechado e ignorado por momentos, salvo cuando era funcional a productos novedosos. El archivo era eficaz en tanto era rescatado por el valor e importancia que presenta como documento histórico. El laboratorio de Cinecolor ubicado en la localidad de Olivos, Buenos Aires, Argentina cerró sus puertas en el año 2016. Era el último laboratorio de revelado fílmico de América Latina. El predio fue donado al Estado y finalmente, luego de años de una ley que lo indicaba se fundó la Cinemateca Nacional, CINAIN, que pretende ocupar el predio de los antiguos laboratorios privados. Al mismo tiempo Kodak abre un nuevo laboratorio en Gran Bretaña. El estado, el mercado y la cultura continúan permaneciendo en una red intrínseca que responde a las necesidades de la una u la otra. CINAIN funciona en tanto existen una gran parte de la historia de la cinematografía argentina, no sólo ficcional, sino por ejemplo los centenares de latas de celuloide que perteneces a los episodios de Sucesos Argentinos, necesitan ser restaurados y digitalizados para su posteridad y exhibición. Este tipo de material, el archivo, acerca el pasado a la audiencia, no solo por las texturas del fílmico y que se observan en imagen, sino por los diálogos y utilización de la música si la hay. De alguna manera hace el pasado tangible por un breve período de tiempo, el contrato de imagen - tiempo que firman tácitamente los espectadores al acceder a este material antiguo. Sin embargo ¿Qué sucede cuando el material de archivo es utilizado en nuevos contenidos? Este al igual que el found footage es intervenido y editado junto a imágenes nuevas o a manera de collage audiovisual para crear nuevos mensajes. Noriega lo define "Como el fenómeno es todo menos homogéneo, las prácticas de found footage, en plural, plantean la convergencia de al menos tres -grandes y difusos- campos de estudio: el cine, las prácticas artísticas y el concepto de archivo" (2012, p. 136).

El contrato con la audiencia es otro, para ambos hay un público si bien uno linda con los límites de una construcción histórica con pretensión de objetividad y el otro con un estudio antropológico subjetivo del estilo de vida moderna que ha llegado a su fin. Ambos responden a una construcción histórica que ha sufrido la incertidumbre de la posmodernidad debido a los diálogos y re visión del pasado y quien cuenta los sucesos, todo entra en un cuestionamiento y juicio sobre su veracidad. Baron (2014) expresa que existe un deseo por parte de los espectadores de creer y entender que el archivo y la apropiación el archivo, brindan una autoridad para la construcción de un marco teórico sobre el documento que 
están visualizando. A la misma vez que algunos archivos fílmicos funcionan para refutar ciertos momentos o por lo menos cuestionar su veracidad, como por ejemplo la llegada del hombre a la luna.

Dentro de la clasificación de archivo, además, se encuentran las películas caseras o aquellas encontradas, realizadas por amateurs o profesionales y no pertenecen a ninguna colección. Este tipo de películas que fueron creadas pensando en un público privado, se convierten en dominio público y exhiben pequeñas micro narrativas que sirven para entender eventos y contextos pasados. Encuentra su función en las posibilidades performativas del material y la experimentación con el archivo cultural, el uso, remix, y collage de material con libertad para su uso al no tener autor. El mismo nace como recurso ante los precios del mercado del material proveniente de bancos de imágenes fijas y móviles. El video arte se re inventa con esta propuesta de archivos de dominio público que han sido trasvasados de su medio original a uno digital. Internet y las redes facilitan su distribución y accesibilidad. La apropiación, edición y re utilización de los mismos colaboran con búsquedas artísticas que intentan encontrarse al margen del mercado, idiosincráticamente o circunstancialmente.

Las relaciones que se suscitan entre un artista del found footage y el material por él apropiado no son simplemente mecánicas o programáticas, sino más bien contradictorias, se dan en un juego constante de creación y destrucción, tanto del material como de la estructura o el sentido original; en una tensión entre fascinación y rechazo por las imágenes seleccionadas o encontradas y en tensión por los niveles de develación-ocultamiento de sentido entre el original y el nuevo contexto de aparición de estas imágenes y sonidos (Noriega, 2012, p. 137).

\section{Transformación constante}

El cine fue un invento de la modernidad, una suma de técnicas para una nueva herramienta que permitiera la fotografía en movimiento. Las anécdotas dicen que sus propios supuestos creadores no le vieron sentido, ni artístico, ni comercial. Sin embargo, un siglo después el audiovisual se transformó constantemente igual que los avances tecnológicos de esta época. Su herramienta evolucionó de manera tal que la antigua era desechada y en cierta forma los beneficios de la nueva cegaban al público y al realizador, embelesados por las nuevas posibilidades de creación.

El profesor Rockwell (2017) de la Universidad de Nueva York brinda datos interesantes al discurrir sobre las motivaciones y preferencia de los estudiantes en sus cartas de aplicación para acceder a dicha escuela; aún se trabaja con fílmico. Las nuevas generaciones, las que se están formando, no desechan el fílmico, vuelven a este medio para poder aprender a dominar el oficio, y según este profesor lo prefieren por la poética que ofrece. Es decir, el grano, la textura, los diferentes valores tonales y de contraste que ofrece la película cinematográfica en sus variaciones químicas y de formato. Filmar sin saber el resultado exacto al carecer del típico visor digital integrado, trae consigo un romanticismo sobre el trabajo que está siendo realizado. La atención máxima a los detalles, a la composición, a estar listos 
en el momento indicado. Los tiempos, presupuestos y formas de trabajo varían. Sin embargo, se necesita de los laboratorios para poder revelar el material, aprender de aquellos que lo conocen, y son expertos en su manipulación, para poder digitalizarlo y trabajar su edición y posproducción en computadoras.

El digital ofrece múltiples opciones para corrección y edición en la etapa de posproducción, pero pareciera ser que el celuloide no tiene competencia. La integración de ambas maneras de trabajo funciona, para poder, así, exprimir al máximo las posibilidades de cada una para contar historias. Pareciera que el tiempo de dejar atrás medios que se consideran obsoletos ha quedado atrás y el aquí y ahora remonta a trabajar con tecnologías que se conocen y se integran con las actuales. No es el fin del cine, solo una etapa más.

\section{Bibliografía}

Bauman, Z. (2013). La cultura en el mundo de la modernidad líquida. Ciudad Autónoma de Buenos Aires: Fondo de Cultura Económica.

Fujifilm Holdings Corporation (2016). Anual Report. Recuperado el 15 de noviembre de 2017 de https://www.fujifilmholdings.com/en/investors/annual_reports/2016/pack/pdf_ TOP/Annual-Report-2016.pdf

Kelly, T. (2017). Chanel: Not that kind of girl. [Vimeo] Paris: Vogue. Disponible en https:// vimeo.com/239031722

Kodak (2017). Cannes 2017 line-up premieres 15 new films all shot on KODAK. Recuperado el 21 de noviembre de 2017 de https://www.kodak.com/us/en/motion/About/News/ Cannes_2017_line_up_premieres_15_new_films_all_shot_on_KODAK/default.htm

Kodak (2018). Shot on Film. Recuperado el 1 de febrero de 2018 de https://www.kodak. com/lk/en/motion/customers/productions/default.htm

Lipovetsky, G. y Charles, S. (2006). Los tiempos hipermodernos. Barcelona: Anagrama.

Noriega, E. (2012). Notas sobre found footage. Arte e investigación, 8. 136-139. La Plata: Facultad de Bellas Artes.

Rockwell, A. (2017). The Kodakery [Podcast] Disponible en https://soundcloud.com/thekodakery/filmmaker-and-nyu-tisch-film-professor-alexandre-rockwell

Russo, E. (2008). Lo viejo y lo nuevo ¿Qué es el cine en la era del post-cine? En La Ferla, J. (Comp.) Artes y medios audiovisuales: un estado de situación II: las prácticas mediáticas pre digitales y post analógicas. (p. 26-36) Buenos Aires: Nueva Librería.

Abstract: Globally, the social and cultural spheres are going through a crisis that involves a multiplicity of variables. In the face of social instability and the continuous modification of the tools for the production of contents from the different cultural areas, we observe a nostalgic look at the realization and a certain tendency towards historical revisionism. In audiovisual design and communication, discursive and formal instability give rise to an artistic search for analogue and studies on the importance of the audiovisual archive and 
found footage; axiomatically this criterion is understood as a safe action on the known, and an attempt to objectively understand the past.

Keywords: Audiovisual communication - image and sound design - analog film - film digital - revisionism - culture - discourse and form - found footage - archives - restoration - audiovisual tools - Identity and nationalism.

Resumo: Globalmente, as esferas social e cultural passam por uma crise que envolve uma multiplicidade de variáveis. Diante da instabilidade social e da modificação contínua das ferramentas para a produção de conteúdos das diferentes áreas culturais, observamos um olhar nostálgico sobre a realização e uma certa tendência para o revisionismo histórico. No design audiovisual e na comunicação, a instabilidade discursiva e formal dá origem a uma busca artística por analógicos e estudos sobre a importância do arquivo audiovisual e ele found footage, axiomaticamente este critério é entendido como uma ação certeza sobre o conhecido, e uma tentativa de entender objetivamente o passado.

Palavras chave: Comunicação audiovisual - imagem e design sonoro - cinematografia analógica - filme - digital - revisionismo - cultura - discurso e forma - found footage - imagens encontradas - arquivos - restauração - ferramentas audiovisuais.

[Las traducciones de los abstracts fueron supervisadas por el autor de cada artículo] 



\section{A World in Flux. Introduction}

Steven Faerm *

\begin{abstract}
The present state of the world is in flux. Globally, communities and individuals are experiencing tremendous change, instability, transition, mobility, and uncertainty. Amidst this tenuous future, how are artists, designers, and educators responding? How can we prepare and strengthen our future through pragmatic or theoretical means? What is the role of design, the designer, and design education in such pronounced states of flux? It is with this desire to examine, question, and propose new insights into the current global state of flux that we present our journal. The authors consider the contemporary landscape from diverse perspectives and offer speculations and insights in pedagogy, student development, design education, entrepreneurship, economics, design systems, globalization/localization, sustainability, commercial media, sociology, and design practice/ industry.
\end{abstract}

Keywords: design education - student development - entrepreneurship - design partnerships - internships - sustainability - design systems - globalization - localization - fashion media - diversity - consumerism - luxury

[Abstracts in spanish and portuguese on page 158]

${ }^{*}$ Steven Faerm is an Associate Professor of Fashion Design at Parsons School of Design (Program Director, BFA Fashion Design, 2007-2011). A Parsons alumnus (94') and Designer of the Year Nominee, he began teaching in 1998 while working for designers Marc Jacobs, Donna Karan, Kenneth Richard, and more. He has been recognized for his teaching by winning "The University Distinguished Teaching Award" and The School's "Teaching Excellence Award.”

Steven has created college- and pre-college programs and courses for Parsons and other leading international institutions, and has served on academic review boards for Rhode Island School of Design, Pratt Institute, Virginia Commonwealth Institute (VCU), Otis College of Art and Design, and Marist College. He has taught and lectured for institutions including Harvard University, Massachusetts Institute of Technology (MIT), Brown University, Donghua University in Shanghai, The University of Palermo (UP) in Buenos Aires, and The Spero Villioti School in South Africa. Since 2012, he has co-produced an academic journal dedicated to design education between Parsons and UP.

His publications include two books that are featured on international college-level required reading lists and available in seven languages: Fashion Design Course: Principles Practices, and Techniques and Creating a Successful Fashion Collection: Everything You Need 
to Develop a Great Line and Portfolio. He is currently writing a third book about design education and pedagogy while publishing ongoing research studies in academic journals and serving as a consultant for five publishing houses.

Areas of scholarship and research included the future of art and design education, pedagogy, and student development.

\section{Flux [fluhks] (noun)}

1. continuous change, instability, transition, mobility, passage, or movement.

We are in flux. Around the world, communities are experiencing tremendous change, transition, and instability that permeate daily life. It seems everyone shares the same growing concerns given the global scale and subsequent impact of our diverse dilemmas: Donald Trump's presidency; rising terrorism; Brexit and the European Union; conflict in the Middle East; immigration, diaspora, and rising nationalism; the growing economic divide; affordable healthcare; racial and religious tensions; environmental depletion and global warming; and many more. Our contemporary lives are one of ceaseless uncertainty, worry, and anxiety; our thoughts remain fixated on the 'what-ifs' of the globally intertwined political, social, environmental, and economic futures.

Amidst this dense 'fog' of an uncertain and tenuous future, how are artists, designers, and educators reacting and responding? How can we successfully prepare in both short- and long-term situations? How are moments of flux recorded by and reflected in the histories of art and design? Can we learn from the past to prepare and strengthen our future? In the growing tumult, what is the role of design, the designer, and design education? How can practitioners, industries, and/or design educators improve the status quo via pragmatic or theoretical means? As the philosopher Hegel famously noted, "the owl of Minerva spreads its wings only with the falling of the dusk" -we understand a historical condition just as it passes away. How will future scholars and practitioners reflect upon our current period of flux and how we, as design practitioners and design educators, navigated the volatile landscape?

Despite its unstable character, a period of flux can benefit and improve society; history suggests sudden sparks of societal upheaval can elicit profound creativity and progress. Through emotional and even physical hardships, individuals and communities imagine a better world and a better way -no matter how fantastical or mundane- to "escape" their present circumstances. A desperation can take hold from which the creative soul needs to express itself no matter the resources, the outcome, or the application. After all, in dire circumstances, what is there to lose? Throughout history, these creative movements ranged in scope and impact, and encompassed the visual, the textual, and the auditory. The Hippies, Abstract Expressionism, The Beats, The Lost Generation literary movement, Art Deco, The Dadaists, Guerilla Girls, Bauhaus, Die Brücke, Punk music, Russian Futurism, Scuola Metafisica, Experimental Music, and many other artistic movements were all spawned during or shortly after pronounced societal change. The very nature of flux "stirs the pot" and unsettles a dormant, complacent mind. 
It is with this desire to examine, question, and propose new insights into the current global state of flux that we present our journal. The authors were asked to consider the contemporary landscape(s) -including the political, social, economic, environmental, and/or cultural- for their papers. In addition, they were asked to consider how designers and/or design educators can negotiate and/or prepare for such states of pronounced flux via pragmatic or theoretical means. Collectively, the authors' papers address a wide assortment of topics including pedagogy, student development, design education, entrepreneurship, economics, design systems, globalization/localization, sustainability, commercial media, sociology, and design practice/industry.

\section{The Articles}

Steven Faerm in The School of Fashion ( $\mathrm{SoF}$ ) presents a paper that examines stress, anxiety, pedagogy, and college student development. Faerm contextualizes his essay by first discussing the wider context of the U.S. in flux. Across the country, Americans are experiencing great change and unprecedented stress levels due to factors that include political discord, widening economic disparities, increasing gun violence and other forms of terrorism, tensions between world powers, and more. These events are sensationalized and emotionalized as a ceaseless stream of negative news that, in turn, exacerbates viewers' stress and anxiety. Additionally, the extreme use of digital technology -particularly electronic messaging that never allows the user to "unplug"- further weakens emotional and physical health. These and a host of other stressors contribute to the record numbers of undergraduates seeking services for mental health issues. In response, college campuses are seeking ways to improve students' well-being. One method of support dubbed "Contemplative Pedagogy" is gaining widespread attention in higher education. These simple yet highly effective teaching methods aim to decrease stress levels, improve a sense of well-being, and increase "mindfulness" so that students feel more present in the classroom and beyond. Following the contextual overview of the nation, the campus environment, and select factors that are elevating stress levels, Faerm presents four pedagogical methods that can benefit all levels and types of students. By adopting these methods in and out of the classroom, students' emotional and cognitive development are strengthened, thus promoting long-term academic and personal success.

Thomas Werner in The School of Arts, Media, and Technology (AMT) explores the journal's theme of flux by considering how a community's ideals -namely the fashion industry's- are evolving. Werner posits, "Historically, fashion design -and the imagery that defines it- has shown us where our boundaries lie and how we alternately seek to embrace or break them. This applies not only to the garments we wear, but also to the manner in which fashion addresses the social and cultural norms of the era or country in which they are designed, presented, and advertised." Werner notes the design, presentation, and advertising of fashion has been largely homogeneous and centered around specific (often Westernized) "ideals" of body and ethnicity. However, these ideals featured in runway shows, magazine editorials, and advertisements are becoming increasingly questioned and challenged. In his paper, Werner examines this growing conversation from its nascent, his- 
torical beginnings up to select contemporary representations shown across fashion media platforms. By incorporating qualitative and quantitative data, Werner provides readers an overview of the fashion landscape and evidences the lack of varied representation -namely in ethnic representation and body diversity. Although the fashion industry's progress in this topic is slow, Werner concludes by noting there has been an increase of diverse representation in fashion media and, "In the rapidly changing commercial environment, outdated business practices must evolve to reflect the broader community."

Marie Geneviève Cyr in The School of Fashion (SoF) examines the sudden, rapid growth of China's economy -specifically, that of the apparel industry- and how the resultant hyper-consumerism that followed fostered a shifting identity among many Chinese fashion consumers. Cyr postulates that China's rapid economic boom produced "mass-confusion, enthusiasm, rebellion, romanticism, and idealism. The 1990s manufacturing industries continued to dominate the acceleration of consumerism in the $21^{\text {st }}$ century..." The country's accelerated economy and consumerism led many of the nation's emerging elite to seek vast quantities of luxury goods. The spikes in manufacturing and hyper-consumption "gave China the ultimate opportunity to create a new identity for itself while importing the 'dream' of luxury. By transferring Westernized ideas of consumption into visual symbols, production systems, and communication tools, China channeled an idealized fantasy world." While Westernized symbols and goods have been adopted, newer forms that suit local cultural contexts and aesthetics have emerged. Cyr examines the rise of consumerism, quest for individuality, social impact of giant retail spaces, luxury, authenticity, and spirituality to contribute to the study of fashion and globalization. Cyr's paper also echoes the increasing questions around the economic, social, and cultural logics related to consumption and communication of the constructed significances of fashion.

Noël Palomo-Lovinski, Associate Professor at Kent State University, and Steven Faerm in The School of Fashion (SoF) at Parsons challenge contemporary fashion practices by proposing a new system that aims to better support local communities and sustainability. Increasingly, the fashion industry is re-examining its inefficient and environmentally harmful practices. These practices are due in part to consumers' unyielding needs for instant access, constant change, and low prices -all of which increase a corporation's profits. Yet a paradox exists: How can the fashion industry decrease accelerated and destructive practices while remaining profitable? This binary relationship elicits key questions that aim for a better future. What are the possibilities of domestic apparel manufacturing that utilizes innovative production methods, communication technology, and service systems that, in turn, encourage holistic sustainable practices? What are the possibilities and needs of designers who want to take full advantage of this evolving relationship? Thus, the authors propose a Sustainable Product Service System (SPSS). Across the U.S., local hubs would create a locally considered space that promotes site-specific design, manufacturing, and retail in conjunction with a global perspective, presence, and digital distribution of ideas. The authors liken their proposed system to the local organic food movement that "encourages local organic farming, thoughtful consumption, and methods of creating more closed loop systems (such as composting). These farmers and farmers' markets encourage community participation and transparency. So too can the consumable product of clothing become locally based with greater concern for the environment and the people 
it serves." An enhanced form of design education that can train and support future SPSS entrepreneurs concludes the paper.

Anezka Sebek in The School of Arts, Media and Technology (AMT), and John Jones, Senior Vice President of Design Strategy at Fjord, present the final paper. The globally intertwined phenomena that foster the present state of flux are affecting companies that strive to innovate design, improve systems, and remain lucrative. At the same time, design education aims to provide its students with experiences both inside and outside the institution so they may gain the knowledge required in the hyper-competitive job market. These factors are leading traditional internship models to be reimagined so that students are given the most up-to-date knowledge and methodologies for a fluid and successful transition into the design industries. Sebek and Jones describe a unique internship collaboration between Parsons and the globally esteemed design consultancy Fjord. Select graduate-level students in Parsons' Design and Technology Program engage in a one-week Fjord Immersion Program. They join a Fjord team to explore the firm's design methodologies, contribute their knowledge and skills, and successfully complete a project on-site. This work at Fjord "often sits outside of direct client work and is a perfect vehicle to plug students into an intense, structured process." In their paper, the authors present six case studies of students who successfully enrolled and benefitted from the Immersion Program. A rich description of each project's design methods, project briefs, and outcome(s) are provided so that the reader gains an understanding of the students' cognitive and creative development during the collaborative experience. By participating in such innovative internship programs, students gain tangible, "real world experience" while the design firm gains access to the students' unbridled creativity that may improve and strengthen the firm's existing practices.

\section{Parsons School of Design}

As a leader in art and design education, Parsons School of Design in New York City is considering the future of the art and design education and practice through ongoing conversations and evolving academic philosophies. Parsons contains five Schools: The School of Fashion (SoF); The School of Constructed Environments (SCE); The School of Art, Design, History, and Theory (ADHT); The School of Arts, Media, and Technology (AMT); and The School of Design Strategies (SDS). Within each School, graduate and undergraduate programs house disciplines that relate to one another. For example, in AMT, the programs of Fine Arts and Illustration are contained; SCE offers graduate and undergraduate degrees in Architecture and Interior Design; and SoF offers programs in Fashion Design and Fashion Marketing. While these Schools offer students their own areas of disciplinary study, broader philosophies in art and design education are influencing programs' academic frameworks and curricula in order to contextualize each student's area of study; the importance for this breadth -and depth- has even led to the creation of a graduate-level interdisciplinary program and undergraduate course pathways that allow students to experience multiple Schools and the broader New School University offerings, thus supporting the belief that "design thinking" and cross-disciplinary partnerships may reshape design education and professional practice. 
Resumen: El estado actual del mundo está en movimiento. A nivel mundial, las comunidades y las personas están experimentando cambios tremendos, inestabilidad, transición, movilidad e incertidumbre. En medio de este tenue futuro, ¿cómo responden los artistas, los diseñadores y los educadores? Cómo podemos preparar y fortalecer nuestro futuro a través de medios pragmáticos o teóricos? ¿Cuál es el papel del diseño, el diseñador y la educación del diseño en estados de flujo tan pronunciados? Es con este deseo de examinar, cuestionar y proponer nuevos conocimientos sobre el estado actual de flujo global que presentamos a nuestra revista. Los autores consideran el paisaje contemporáneo desde perspectivas diversas y ofrecen especulaciones y perspectivas en pedagogía, desarrollo estudiantil, educación de diseño, emprendimiento, economía, sistemas de diseño, globalización / localización, sostenibilidad, medios comerciales, sociología y práctica / industria del diseño.

Palabras clave: Educación en diseño - desarrollo estudiantil - emprendimiento - asociaciones de diseño - pasantías - sostenibilidad - sistemas de diseño - globalización - localización - medios de la moda - diversidad - consumismo - lujo.

Resumo: O estado atual do mundo está em movimento. Globalmente, comunidades e pessoas estão experimentando mudanças tremendas, instabilidade, transição, mobilidade e incerteza. Em meio a esse futuro tênue, como artistas, designers e educadores respondem? Como podemos preparar e fortalecer nosso futuro através de meios pragmáticos ou teóricos? Qual é o papel da educação em design, design e design em estados de fluxo tão pronunciados? É com esse desejo que examinamos, questionamos e propomos novos conhecimentos sobre o estado atual do fluxo global que apresentamos ao nosso periódico. Os autores consideram a paisagem contemporânea a partir de perspectivas diversas e oferecem especulações e perspectivas em pedagogia, desenvolvimento de estudantes, educação de design, empreendedorismo, economia, sistemas de design, globalização / localização, sustentabilidade, mídia comercial, sociologia e prática / design.

Palavras chave: Educação em design - desenvolvimento de estudantes - empreendedorismo - associações de design - estágios - sustentabilidade - sistemas de design - globalização - localização - moda - diversidade - consumismo - luxo.

[Las traducciones de los abstracts fueron supervisadas por el autor de cada artículo] 
Fecha de recepción: abril 2019

Fecha de aceptación: octubre 2019

Versión final: marzo 2020

\section{Contemplative Pedagogy in the College Classroom: Theory, Research, and Practice for Holistic Student Development}

Steven Faerm *

\begin{abstract}
Across the U.S., college campuses are witnessing escalating numbers of undergraduates experiencing emotional challenges. Students face an increasingly unstable and uncertain world due to rising political discord, terrorism, tensions between world powers, and more. Additional factors are further impacting college students' emotional health. Research shows excessive engagement with digital technology -such as the high frequency of electronic messaging- negatively affects users' sense of well-being. The extreme volumes of texts and tweets sent and received prevent people from feeling "unplugged" and present during any given situation; multitasking has become the normative behavior for professionals and students alike. Over time, these stresses weaken students' cognitive, emotional, and physical health, and contribute to the record numbers of undergraduates seeking services for mental health issues.

In response, many U.S. colleges are adopting pedagogical techniques that target students' mental health. Dubbed "Contemplative Pedagogy," these simple yet highly effective methods aim to decrease stress levels, improve a sense of well-being, and increase "mindfulness" so that students feel more present in the classroom and beyond. By adopting these pedagogical methods, students' emotional and cognitive development is strengthened. This paper aims to provide educators with an awareness of the rising emotional challenges experienced by college students today. This paper also provides educators with practical methods for incorporating contemplative pedagogy techniques into their classrooms for students' academic and personal success.
\end{abstract}

Keywords: contemplative pedagogy - student development - pedagogy - teaching and learning - wellness - stress management.

[Abstracts in spanish and portuguese on pages 181-182]

${ }^{*}$ Steven Faerm is an Associate Professor of Fashion Design at Parsons School of Design (Program Director, BFA Fashion Design, 2007-2011). A Parsons alumnus ('94) and Designer of the Year Nominee, he began teaching in 1998 while working for designers Marc Jacobs, Donna Karan, Kenneth Richard, and more. He has been recognized for his teaching by winning "The University Distinguished Teaching Award" and The School's "Teaching Excellence Award."

Steven has created college- and pre-college programs and courses for Parsons and other leading international institutions, and has served on academic review boards for Rhode Island School of Design, Pratt Institute, Virginia Commonwealth Institute (VCU), Otis 
College of Art and Design, and Marist College. He has taught and lectured for institutions including Harvard University, Massachusetts Institute of Technology (MIT), Brown University, Donghua University in Shanghai, The University of Palermo (UP) in Buenos Aires, and The Spero Villioti School in South Africa. Since 2012, he has co-produced an academic journal dedicated to design education between Parsons and UP.

His publications include two books that are featured on international college-level required reading lists and available in seven languages: Fashion Design Course: Principles Practices, and Techniques and Creating a Successful Fashion Collection: Everything You Need to Develop a Great Line and Portfolio. He is currently writing a third book about design education and pedagogy while publishing ongoing research studies in academic journals and serving as a consultant for five publishing houses.

Areas of scholarship and research included the future of art and design education, pedagogy, and student development.

\section{Introduction}

The growing prevalence of anxiety and depression [among students] represents a substantial challenge for colleges and universities. Institutions and counseling centers will need to work together to develop and offer a continuum of options to educate and support both students seeking counseling services as well as the general student body (e.g., prevention, education, self-help, and expanded treatment capacity).

-Center for Collegiate Mental Health

The recent phenomena of increasing numbers of U.S. college students experiencing emotional challenges -such as stress, anxiety, and depression- is alarming many of the nation's institutions of higher education. These statistics are leading many college educators and administrators to examine the possible factors affecting undergraduates' emotional health and academic performance. Their goal is to address these issues for their students' successes both in college and beyond.

The possible factors are vast given the complexities of contemporary culture and society. College students -and the broader U.S. population- face a progressively unstable, tenuous, and stressful world. A national survey conducted by the American Psychological Association (2017) identified the leading causes of the sudden spike in Americans' stress levels. They include the nation's tumultuous political climate, escalating terrorism and gun violence, tensions between world powers, rising police aggression, and general concerns over personal safety and the nation's future (American Psychological Association [APA], 2017). These events are sensationalized by the constant stream of negative news that is aired across media platforms, thus permeating diverse communities and elevating stress levels on the national level. Collectively, these factors are contributing to the record numbers of undergraduates experiencing emotional challenges (Brown, 2016). 
Additional cultural factors are further compromising college students' emotional health. The ubiquitous nature of smartphones, electronic messaging, and social media are dominating most Americans' lives - particularly those of college students who cite electronic messaging as their preferred form of communication (Straumsheim, 2016). While these technologies can be beneficial to our lives, research indicates excessive engagement with digital technology negatively affects the users' overall sense of well-being (Turkle, 2015). For example, the extreme volumes of text messages sent and received have a particularly detrimental effect on users' emotional health; the constant influx of messages fosters a state of anxiety and urgency to respond, no matter the recipient's present situation and activity (Krauss Whitbourne, 2013). Consequently, multitasking has become normative behavior for many professionals and students alike, thus elevating stress levels that weaken cognitive, emotional, and physical health (Levitin, 2015). This widely practiced behavior -and its associated detriment to well-being-contributes to the increasing numbers of college students seeking services for mental health issues on U.S. campuses today (Center for Collegiate Mental Health [CCMH], 2017).

The growing numbers of students experiencing emotional challenges is alarming many colleges and universities. At Boston University alone, there was a 40 percent increase in students seeking mental health services between the academic years of 2014-2015 and 2015-2016 (Brown, 2016). Across the U.S., anxiety is the leading mental health issue facing college students, with 62 percent visiting campus health clinics listing it as a concern (CCMH, 2017). The American College Health Association's (ACHA) annual survey of 93 national institutions and nearly 48,000 undergraduates revealed one in five respondents (20.9 percent) had been diagnosed with, or treated for, anxiety -an increase of 122 percent since 2009 (9.4 percent) (ACHA, 2010; ACHA, 2017). The subsequent impact anxiety has on learning is also widespread: more than one in four respondents (26.2 percent) cited anxiety as a factor that impacted their individual academic performance (ACHA, 2017). The pronounced rise of anxiety levels among college students is especially alarming given, "anxiety and depression have shown year-over-year increases in their frequency whereas other concerns are either flat or decreasing" (CCMH, 2017, p. 9).

In response to these rising statistics, many institutions are incorporating pedagogical techniques that target students' mental health. Termed "contemplative pedagogy," the simple yet highly effective methods aim to alleviate anxiety, decrease stress levels, improve a sense of well-being, and increase "mindfulness" so that students feel more present in the classroom and beyond. Research suggests that by adopting these pedagogical methods, students' emotional and cognitive development is strengthened (Center for Teaching at Vanderbilt University, 2018). Through sustained practice, these techniques learned during the college years can continue well into adulthood for a more mindful and emotionally satisfying life.

This paper aims to provide educators, program directors, and administrators with an awareness of the rising emotional challenges experienced by college students. While there are numerous and extended factors that contribute to emotional health, the scope of this paper will address key topics that have gained increased attention and subsequent research in recent years. These topics include the unprecedented political tumult caused by the U.S. 2016 election, widespread unease about the nation's future, growing concerns for personal 
safety, increasing engagement with social media and negative news, decreasing socialization among college students, excessive use of digital technology that prevents users from feeling "unplugged", and the harmful effects of multitasking on mental health. This paper will then focus on the recent key factors in the university context that are impairing undergraduates' emotional health. In conclusion, this paper will provide educators with select practical methods for incorporating contemplative pedagogy techniques into their classrooms for students' academic and personal success. These methods include journaling, "beholding", meditation, and silent sittings.

\section{Rising Stress Levels in the U.S. and Key Contributors}

Since its inception in 2007, the annual "Stress in America" survey conducted by the American Psychological Association (APA) has revealed Americans' stress levels -consistently led by the factors of money, work, and the economy- gradually declined over the years (APA, 2017a). However, this changed in January 2017 when the survey showed a statistically significant increase in reported stress among respondents since the previous report's findings just five months earlier (APA, 2017a). This sudden rise in stress levels coincided with a particularly capricious event: the recent political tumult caused by the nation's 2016 presidential election. Caroline Vaile Wright, Director of Research and Special Projects at the Association, notes:

Americans' stress levels in January were worse than in August, in the middle of the angriest, most personal campaign in recent memory, when some believed the anxiety would abate after the election. At 57 percent, more than half of respondents said the current political climate was a very or somewhat significant source of stress (as cited in Shanker, 2017, n.p.).

The political discord has widened social divides and contributes to Americans' uncertainties about their nation's future; a full two-thirds of respondents (66 percent) reported the nation's future is a very or somewhat significant source of stress (APA, 2017a). The survey also revealed the new leading cause of stress among Americans is the nation's future (63 percent), followed by money (62 percent), work (61 percent), the current political climate (57 percent), and violence and crime (51 percent) (APA, 2017b). Stress levels are so peaked that more than half of Americans (59 percent) reported the time period to be the lowest point in the nation's history they can remember -"a feeling that spans generations, including individuals who have lived through World War II and Vietnam, the Cuban Missile Crisis, the September 11 terrorist attacks, and high-profile mass shootings" (APA, 2017b, p. 1). Personal safety is another leading concern contributing to the sudden spike in stress levels; 34 percent of respondents -the highest level since 2008 (31 percent) - are worried about personal safety (APA, 2017a). Terrorism is an especially high and widespread concern, with 60 percent of respondents listing it as their top worry in the category of personal safety (APA, 2017b). This data is particularly salient when compared to the previous year's findings of Americans concerned over terrorism (51 percent) and the ten-year average (34 
percent) (APA, 2017a). Additional areas of personal safety concerns chosen by respondents include police violence against minorities (50 percent), gun violence (55 percent), and hate crimes (52 percent). (APA, 2017b). Across the nation's communities, these widelyexperienced fears are growing, elevating anxiety and stress levels, and affecting well-being. Americans' high consumption of news sources that profile these events with increased regularity and explicit content are aggravating their stress levels (Hampton, et al., 2015). Virtually all Americans (95 percent) follow the news regularly, with approximately one in ten checking the news every hour (APA, 2017b). Social media contributes to this high exposure, with one in five Americans (20 percent) stating they check their social media accounts regularly -an increase from 17 percent in 2016 (APA, 2017b). Lynn Bufka, APA's Associate Executive Director for Practice Research and Policy, underscores the extreme volume of news consumption in today's world by asserting, "It's everywhere -newspapers, social media, even elevators have screens now that push news at you. As consumers, it can be really difficult to know when we have enough information about our world" (as cited in Boddy, 2017, n.p.).

The impact of news and social media on viewers' lives has been widely studied in recent decades. However, the rapidly increasing volume of negative news that emotionalizes and sensationalizes stories for higher ratings is gaining increased attention due to its harmful effect on viewers' mental health (Davey, 2012). Doctor Graham C.L. Davey, Professor of Psychology at The University of Sussex, asserts long-term viewing of negative news not only makes the viewer sadder and more anxious, it is also likely to exaggerate and exacerbate the viewer's personal anxieties through persistent worry (Davey, 2012). Further, in a study of media exposure to the 2013 Boston Marathon bombings, "researchers found that extensive, repeated engagement with media coverage of the bombings was associated with even more acute stress than actually witnessing the event in person" (Holman, Garfin, \& Silver, 2014).

This high exposure to negative news can also foster a decreased ability to cope with stress. Research suggests the increasing amounts of time devoted to news consumption (via televisions, computers, smartphones, and other technologies) is preventing Americans from "unplugging," thus decreasing time spent in face-to-face communication and socialization (Turkle, 2015; Brody, 2017). Doctor Harsh Trivedi, President and Chief Executive Office of Sheppard Pratt Health System, notes:

In the past, you may go out and meet with your friends and talk about something, but when you got home you'd go to sleep. The difficulty now is you can't really turn things off. We don't necessarily have downtimes to recharge and get our bearings straight again (Thompson, 2017, n.p.).

Yet, for decades, medical science research has shown positive social interaction promotes and strengthens physical and emotional health (Brody, 2017). In one longitudinal study, researchers found that people who lacked adequate social engagement were nearly three times more likely to die during the nine-year study than people with strong social ties (Berkman \& Syme, 1979). Conversely, strong social connections promote physical health. Emma Seppälä, Science Director of Stanford University's Center for Compassion and Al- 
truism Research and Education and author of The Happiness Track (2016), states strong social connection leads to a 50 percent increase in longevity, strengthens the body's immune system, and speeds recovery from disease (Seppälä, 2014). Social engagement also contributes to emotional health and general sense of well-being. Seppälä (2014) asserts:

People who feel more connected to others have lower levels of anxiety and depression. Moreover, studies show they also have higher self-esteem, greater empathy for others, are more trusting and cooperative and, as a consequence, others are more open to trusting and cooperating with them. In other words, social connectedness generates a positive feedback loop of social, emotional and physical well-being.

Unfortunately, the opposite is also true for those who lack social connectedness. Low levels of social connection are associated with declines in physical and psychological health as well as a higher likelihood for antisocial behavior that leads to further isolation. (n.p.)

The value and benefits of socialization that alleviate stress and improve well-being are highly germane to undergraduates who experience significant emotional challenges during their adjustment to college life. However, research shows socialization among college students has decreased rather than increased. The annual survey conducted by the University of California, Los Angeles' Higher Education Research Institute found that incoming students at four-year colleges and universities, "devoted half as many hours to hanging out with friends during their final year of high school as students who entered college in 1987" (Eagan, Stolzenberg, Ramirez, Aragon, Suchard, \& Hurtado, 2014). Research findings also revealed a 74 percent decrease of students spending six or more hours "partying" each week since 1987 (Eagan, et al., 2014).

These, and other recent phenomena, are contributing to the ever-rising stress levels among Americans. According to APA's survey, stress levels rose from 4.8 (August 2016) to 5.1 (January 2017) on a 10-point scale (APA, 2017a). The survey's data also reveals a 33 percent increase in the number of adults who experienced "extreme stress" in the five-month period (Welch, 2016). Statistics among college students echo these findings. When students were asked to rank their emotional health in comparison with their peers, "Nearly twelve percent rated their emotional well-being as below average, a figure that stood at three-and-a-half percent in 1985" (Eagan, et al., 2014).

The widespread increase in stress levels -and resultant decrease in well-being- is producing dire situations for many Americans. According to the National Institute for Occupational Safety and Health, stress-related ailments cost companies about $\$ 200$ billion USD per year in increased absenteeism, tardiness, and the loss of talented workers (Der Hovanesian, 2003). In certain instances, sustained levels of extreme stress can lead to debilitating anxiety, depression, mental illness, and self-harm. The nation's rising suicide rate is particularly alarming; suicide is the second leading cause of death in the U.S. for those between the ages of fifteen and thirty-four and doubled for teen girls between 2007 and 2015 alone (National Center for Injury Prevention and Control, 2017; Lewis, 2017). Between 1975 and 2015, suicides increased 26 percent for those between the ages of fif- 
teen and nineteen, with approximately 1,100 suicides per year on college campuses today (Morbidity and Mortality Weekly Report, 2017; Beresin, Schlozman, \& Abdu-Glass, 2017). Despite these alarming statistics and critical need for support systems, access to mental healthcare is worsening partly due to the national shortage of mental health professionals (Thompson, 2017). As these national statistics grow, particularly among young adults, it is incumbent upon colleges and universities to increase campus support services that aggressively target students' emotional health and well-being.

\section{The Rise of Digital Technology and Attendant Stressors}

It makes sense to wonder if the use of digital technology creates stress. There is more information flowing into people's lives now than ever -much of it distressing and challenging. There are more possibilities for interruptions and distractions. It is easier now to track what friends, frenemies, and foes are doing and to monitor raises and falls in status on a near-constant basis. [...] These technologies are said to takeover people's lives, creating time and social pressures that put people at risk for the negative physical and psychological health effects that can result from stress.

-Hampton, Rainie, Lu, Shin, \& Purcell

Digital technology is a dominant part of daily life in contemporary society and culture (Turkle, 2015). One of the most pervasive forms of technology to emerge in recent decades has been the cell phone. "Like the television in the 1950s and Internet in the 1990s, mobile telephony has emerged as one of the defining technologies of our time" (Campbell \& Park, 2008 , p. 371). The ubiquitous presence of cell phones in the U.S. is suggested by the 95 percent of Americans who own the device today, up from just 62 percent in 2002 (Anderson, 2015). Specifically, the adoption of "smartphones" by Americans has more than doubled in just five years, from 35 percent in 2011 to 77 percent in 2016 (Anderson, 2015).

The increase of cell phone ownership coincides with the spiked increase in their usage, particularly with smartphones due to these devices' advanced functionalities. Neuroscientist Daniel Levitin (2015) notes:

Our smartphones have become Swiss army knife-like appliances that include a dictionary, calculator, web browser, email, Game Boy, appointment calendar, voice recorder, guitar tuner, weather forecaster, GPS, texter, tweeter, Facebook updater, and flashlight. They're more powerful and do more things than the most advanced computer at IBM corporate headquarters 30 years ago (n.p.).

The technology offered in smartphones enable users to access the internet with great mobility, and thus serve as an access point for a wide array of important life events. For example, recent surveys among smartphone owners show 62 percent have used their phones to manage finances and receive information about health concerns, while another 18 percent have used their smartphones to submit job applications (Rainie \& Perrin, 2017). 
These, and other convenient services offered by smartphones, has led to extreme usage and subsequent dependency. A recent poll found most users check their smartphone 150 times per day -or, every six minutes-in a sixteen-hour day (Brody, 2017). Smartphone usage is especially high among teenagers; 80 percent sleep with their phones and 25 percent check their smartphone within five minutes of waking up (Turkle, 2015). Given these statistics, it is unsurprising that approximately 50 percent of adults believe their smartphone is something they can't live without (Rainie \& Perrin, 2017). Industries are responding with a range of services that include hotels and resorts that offer "tech-free" vacations for greater relaxation, and psychologists who provide treatment for cell phone addiction. Another primary reason for extreme smartphone usage in the past decade has been its technology that enables users to communicate easily and efficiently through short message service (SMS: text messaging). Between 2007 and 2017 there has been a 200 percent increase in the number of text messages sent by the average user (Statistic Brain, 2017). The volume of text messaging is notably high among young adults between the ages of eighteen and twenty-four who view email messaging as "outdated" and exchange an average of 110 text messages per day, totaling 3,200 texts per month (Levitin, 2015; Smith, 2011). Teens and young adults use text messaging more than any other age group -and use their cell phones for voice-to-voice communication less frequently than any other age group (Rainie \& Keeter, 2006; Reid \& Reid, 2007). In a recent survey of 315 students conducted by Bowling Green State University, respondents listed their primary methods of communication as texting (50.2 percent), social media (35.2 percent), email (12.1 percent), and phone calls (2.2 percent) (Straumsheim, 2016). Text messaging has become such a ubiquitously preferred method of communication among teens and young adults that Crisis hotlines have begun accepting calls from at-risk youth via texting (Levitin, 2015).

In addition to text messaging, advanced digital technology has also contributed to the excessive volume of electronic messaging (email) sent and received via computer and smartphones. According to the Radicati Group (2017), the quantity of emails sent globally in 2017 averaged 269 billion per day, an increase of 9 percent in eight years. The volume of emails experienced on a daily basis has risen dramatically in the professional sectors; in 2012, the typical business user sent and received approximately one-hundred electronic messages daily, and by the end of 2018 that number is expected to increase to 140 (Radicati, 2011; Radicati, 2014).

The excessive and constant volume of text messages and emails has led many users to feel compelled to respond no matter the situation or context. Levitin (2015) postulates:

Text messages magically appear on the screen of your phone and demand immediate attention from you. Add to that the social expectation that an unanswered text feels insulting to the sender, and you've got a recipe for addiction: you receive a text, and that activates your novelty centres. You respond and feel rewarded for having completed a task (even though that task was entirely unknown to you 15 seconds earlier) (n.p.).

According to research performed at University of California, Irvine, the average worker checks his or her email seventy-four times a day-or nine times per hour in a typical eight- 
hour workday (Evans, 2014). This inability to "turn-off" from email and text messaging is affecting nearly every facet of daily life for most Americans, as shown in a recent survey commissioned by Adobe Systems Inc. (Orlofsky, 2016). The online survey, comprised of four-hundred U.S. "white-collar" workers, found that:

- Nearly 80 percent of respondents said they look at emails before going into the office;

- Forty-five percent of eighteen to thirty-four-year-olds open emails upon waking up;

- An average of 6.3 hours is spent each workday checking emails;

- Eighty-seven percent looked at business emails outside of working hours;

- Half of the respondents monitored emails during their vacations.

Many scholars and researchers speculate the reason people aren't "unplugging” from email and text messaging and contributing to these escalating statistics is because human multitasking -dealing with more than one task at the same time- is the expected, normative behavior in the workplace, the home, and the classroom. The majority of Americans believe engagement in multiple activities in one timespan will increase productivity and allow more free-time (Cherry, 2017). This behavior is encouraged through advertising and social media that promote performing multiple activities at one time is better. For example, a recent advertorial article published in The Guardian for a new automobile featured the headline claim that "drivetime is no longer downtime" since the car's smart technology enables drivers to check their calendars and use other software applications while driving. Audiences are pressured to adopt such normative multitasking behaviors through these advertising themes since, as author Cal Newport (2016) asserts, "what makes social media insidious is that the companies that profit from your attention have succeeded with a masterful marketing coup: convincing our culture that if you don't use their products you might miss out" (n.p.).

The proclivity to multitask is also attributable to the neurochemical high it produces. Research suggests that performing multiple activities in one timespan causes the brain to release dopamine -a neurotransmitter that helps control the brain's reward and pleasure centers (Halonen, 2014). When multitasking is performed with consistency over time, a connection between the activity and pleasure is sustained to produce habitual behavior. As furthered by Levitin (2015):

Multitasking creates a dopamine-addiction feedback loop, effectively rewarding the brain for losing focus and for constantly searching for external stimulation. To make matters worse, the prefrontal cortex has a novelty bias, meaning that its attention can be easily hijacked by something new -the proverbial shiny objects we use to entice infants, puppies, and kittens. The irony here for those of us who are trying to focus amid competing activities is clear: the very brain region we need to rely on for staying on task is easily distracted. We answer the phone, look up something on the internet, check our email, send an SMS, and each of these things tweaks the novelty- seeking, reward-seeking centres of the brain, causing a burst of endogenous opioids (no wonder it feels so good!), all to the detriment of our staying on task. It is the ultimate empty-caloried brain 
candy. Instead of reaping the big rewards that come from sustained, focused effort, we instead reap empty rewards from completing a thousand little sugarcoated tasks (n.p.).

Despite these pleasurable sensations, research shows our brains are not well-suited for multitasking. Earl Miller, neuroscientist at the Massachusetts Institute of Technology (MIT) and internationally recognized expert on divided attention states the human brain is not wired to multitask well. Miller posits, "When people think they're multitasking, they're actually just switching from one task to another very rapidly. And every time they do, there's a cognitive cost in doing so" (as cited in Levitin, 2015, n.p.). The impairment of cognition during multitasking was shown in one study conducted by former professor of communication at Stanford University Clifford Nass, whose research examined the individual differences associated with multitasking. Nass' findings revealed heavy multitaskers were worse at sorting out relevant information from irrelevant details and switching from one task to another was exceedingly difficult (Ophir, Nass, \& Wagner, 2009). Furthermore, contrary to widely held beliefs, multitasking can actually reduce productivity by as much as 40 percent (Cherry, 2016).

Multitasking behavior is highly prevalent amongst undergraduates who have grown up with digital technology, particularly texting which "was a landmark in the unfolding of the multitasked life" (Turkle, 2016). As Professor of the Social Studies of Science and Technology at MIT, Sherry Turkle (2015) notes in her book Reclaiming Conversation: The Power of Talk in the Digital Age, "By 2012, nine in ten college students said that they text in class" (p. 213). It is not uncommon, then, for college students to text friends while studying, making a meal, listening to music, and searching the internet. When the student's attention is spread across multiple tasks -rather than "unitasking" on the homework itself- there are significant pitfalls. Assignments take longer to complete, thus leading to less socialization and rest; the students experience mental fatigue due to dropping in and out of the material and having to recall what was reviewed; memory is impaired due to the divided attention; and consequently, as shown in numerous studies, grades decline (Paul, 2013).

The impact multitasking can have on cognitive functioning -and students' academic success- is pronounced. Research conducted by renowned neuroscientist Russ Poldrack at Stanford University shows that "...learning information while multitasking causes the new information to go to the wrong part of the brain" (as cited in Levitin, 2015). For example, if a student studies while watching television or texting, the information from the coursework enters the striatum (a region for storing new procedures and skills and not facts and ideas) rather than the hippocampus (where it is organized in ways that make it easier to retrieve) (Levitin, 2015). Moreover, there is mounting evidence that suggests simply having the opportunity to multitask is harmful to cognitive performance. In one scenario, the distraction caused by an unread email in an inbox while trying to study can reduce a student's intelligence quotient (IQ) by ten points (Levitin, 2015). Further, studies also reveal that the cognitive losses from multitasking are even greater than those from smoking marijuana (Levitin, 2015).

Multitasking diminishes our abilities to stay mentally organized, focused, productive, and mindful. Researchers and scholars agree that if peak performance is to be achieved in and 
outside the classroom, one must work for extended periods of time on a single task free from distraction. The high level of concentration required on "unitasking" builds focus skills over time; this cultivates a deeper engagement in the work and associated tasks, thus enabling higher levels of quality in outcomes (Levitin, 2015).

\section{The University Context: College Students and Emotional Health}

For most undergraduates, the college experience is a profoundly transformative experience. This period of young adulthood requires them to grapple with personal, social, academic, and developmental challenges during a relatively short time span (Deckro, et al., 2002; Towbes \& Cohen, 1996). As undergraduates, they are required to learn new and complex material, manage increased academic workload, navigate unfamiliar social settings, and make enduring decisions for their personal and professional futures. The college experience can be volatile and filled with uncertainty as young adults also must grapple with emotional and physical maturation, increasing independence and self-reliance, and the formation of their own identities.

The stress experienced during this routine development is exponentially compounded by factors that were absent just a decade ago. Today's young adults must operate in a world that is infinitely more complex, competitive, and arduous than it was ten years ago. Statistics show the sheer quantity of students choosing to enter undergraduate programs has increase by 5.1 million since 2000 to 20.4 million in 2017 (National Center for Education Statistics, 2017). Correspondingly, acceptance rates have plummeted in the past ten years. For example, between 2007 and 2017 acceptance rates at the University of Chicago dropped 75 percent, Northwestern University 66.4 percent, Vanderbilt University 68.6 percent, the University of Pennsylvania 55.6 percent, the University of Michigan 52.2 percent, and Swarthmore College 57.5 percent (IvyWise, 2018). To gain entrance to leading schools, students must over-achieve in their high school academic performance, extracurricular activities, volunteer work, and other credentials required by college admissions committees. Consequently, students' emotional health, stress levels, and general sense of well-being are often compromised as they try to out-perform their peers in order to enter the college of their choice. A recent study published by the journal Pediatrics (2016) found a 37 percent increase in teenagers reporting a major depressive episode between 2005 and 2014 (Mojtabai, Olfson, \& Han, 2016).

Once enrolled, students face college tuition costs that have risen over 1,200 percent in just thirty-eight years (Jamrisko \& Kolet, 2014). To pay such exorbitant fees, student loan debt has reached an all-time high, with the average undergrad owing $\$ 35,000$ U.S. dollars upon graduation, thus contributing to the $\$ 1.3$ trillion U.S. dollars in national student loan debt (Sparshott, 2015; Kane, 2016). As a result, 70 to 80 percent of all U.S. college students are working jobs while enrolled, with 40 percent working at least thirty hours per week (Carnevale, Smith, Melton, \& Price, 2005). Moreover, approximately 25 percent of working learners are simultaneously employed full-time and enrolled in school full-time (Carnevale, Smith, Melton, \& Price, 2015). The plight of affording college in the $21^{\text {st }}$ century is particularly poignant when comparing generations. As Carnevale, et al. (2015) assert: 
You can't work your way through college anymore. A generation ago, students commonly saved for tuition by working summer jobs. But the cost of college now makes that impossible. A student working full-time at the federal minimum wage would earn $\$ 15,080$ annually before taxes. That isn't enough to pay tuition at most colleges, much less room and board and other expenses (p. 11).

The necessity of employment while fulfilling rigorous academic requirements contributes to the national average of students taking five years to complete their bachelor's degree rather than the traditional four (Shapiro, Dundar, Wakhungu, Yuan, \& Hwang, 2016). These factors, and a host of other increasing stressors facing undergraduates today, cause an array of debilitating physical, behavioral, and emotional effects. Physical symptoms commonly include sweating, headaches, irregular shaking or twitching, chest pain, increased blood pressure, nausea, and/or frequent sickness; behavioral symptoms may include poor work performance, changes in eating habits, irregular sleeping patterns, abnormal failures or delays in responsibilities, decreased sociability, argumentative behavior, self-harm, and/or excessive drug or alcohol usage; and emotional symptoms are often evidenced by reduced patience, restlessness, increased pessimism, anxiety, sadness, and depression (Cohen, 2018). The onslaught of these symptoms alarm undergraduates who are adjusting to a more independent and autonomous lifestyle away from parental protection and guidance, thus exacerbating the emotional challenge.

The sudden decline in college students' mental health can be seen in universities across the U.S. Research findings from the University of California, Los Angeles revealed the emotional health of its incoming students was at its lowest point in thirty years, with nearly one in ten students stating they felt frequently depressed (Eagan et al., 2014). At Boston University, the number of students seeking services for stress related issues increased sharply by 40 percent from 647 in the 2014-2015 academic year to 906 the following academic year (Brown, 2016). Unfortunately, these statistics are not an anomaly; in a recent study of 139 national institutions, the number of students seeking mental health support increased 30 percent between the academic years of 2009-10 and 2014-15, even though student enrollment grew by only 5 percent during that time (Winerman, 2017; CCMH, 2016). The majority of these students seek counseling for anxiety (61 percent), depression (49 percent), and stress (45 percent) (Winerman, 2017; CCMH, 2016).

Despite the increase of undergraduates receiving mental health support, many feel the emotional challenges are too great. Of the 31 percent of students in the U.S. that drop out of college each year, 64 percent report doing so due to mental health related reasons (Shapiro, Dundar, Huie, Wakhungu, Yuan, \& Bhimdiwali, 2017; National Alliance on Mental Illness [NAMI], 2016). The critical nature of providing these students with emotional support during an important stage of their lives is especially salient when considering 75 percent of all mental health conditions begin before the age of twenty-four, and as many as one in five students experiences a mental health issue while in college (NAMI, 2016). Not all stress is negative, however. Research has documented well the beneficial effects moderate stress levels can have on brain performance (Sanders, 2013). As Associate Professor Daniella Kaufer of the University of California, Berkley notes in her studies of the biology of stress, these levels can heighten alertness, improve performance, and boost 
memory (as cited in Jaret, 2015). However, extreme levels of stress adversely impact neurological performance and can impair judgement, concentration, and memory (Shapiro, Brown, \& Astin, 2008; Anderson, Birnie, Koblesky, Romig-Martin, \& Radley, 2014). In one study, college students volunteered to receive injections that raised their cortisol levels (the "stress hormone") before memorizing select information. In mild to moderate levels, the cortisol helped them remember the information when tested on it two days later. However, extreme cortisol levels impaired the students' memory (Goleman, 2006). Heightened, chronic stress elevates the glucocorticoid stress hormones that suppress the production of new neurons in the hippocampus where memory and emotions are associated (Sanders, 2013). This results in impaired memory and over time, particularly with excessive stress caused by life events, hippocampal shrinkage (Greenberg, 2012).

The rising levels of stress among college students -caused by factors that include the increasingly unstable world, the inability to "unplug" from technology and social media, and ongoing multitasking behavior- are compromising college students' emotional, physical, and cognitive development. As a result, unprecedented numbers of U.S. college students are seeking mental health services for depression, anxiety, burnout, and more. As these numbers continue to grow annually and overwhelm staffing and campus resources, colleges are examining new forms of emotional support they may offer their students, including those situated in the classroom setting that target students more broadly.

\section{Contemplative Pedagogy: Aims and Benefits}

If we knew that particular and readily available activities would increase concentration, learning, wellbeing, and social and emotional growth and catalyze transformative learning, we would be cheating our students to exclude it.

- Tobin Hart

The high levels of acute stress increasingly experienced by undergraduates is leading many U.S. colleges and universities to develop supportive initiatives that can be broadly and easily accessed by students. One of these initiatives, termed "contemplative pedagogy," promotes well-being within the classroom and beyond. As denoted by its Latin root contemplari (to observe, consider, or gaze attentively), contemplative pedagogy fosters a deeper sense of mindfulness and presence that complements traditional education. Tobin Hart (2004), professor of psychology at the University of West Georgia and author of The Secret Spiritual World of Children (2003), notes:

Inviting the contemplative simply includes the natural human capacity for knowing through silence, looking inward, pondering deeply, beholding, witnessing the contents of our consciousness, and so forth. These approaches cultivate an inner technology of knowing and thereby a technology of learning and pedagogy... (pp. 29-30). 
Contemplative pedagogy is "designed to quiet and shift the habitual chatter of the mind to [enable] a capacity for deepened awareness, concentration, and insight" (Hart, 2004, p. 29). The pedagogy acts as an antidote to our hyper-accelerated, fragmented, and multitasking world in which students operate moments before entering the classroom. When teachers and students engage with these contemplative practices -such as guided meditation, journaling, silent sittings, deep listening, exercises with the body, and freewritingthe body is "quieted," the mind becomes more focused, and a greater sense of the "here and now" develops in the student. Deeper learning ensues since:

What we know of effective learning is that the predominant factor is not merely time on task; it is the quality of attention brought to that task. If our attention is somewhere else, we may have little capacity to be present. Paradoxically, we may need to not do for a few minutes to be more available for doing the task at hand (Hart, 2004, p. 35).

Contemplative practices -particularly when performed before and/or during class sessions- grant students this mental pause to refocus their attention for better learning. Research suggests a wide array of mental and physical health benefits result from contemplative practice; these range from those that are experienced suddenly and temporally, to those that build and strengthen over time. Hart (2004) posits:

Among the main state effects (immediate changes) of meditation are physiological relaxation and slowed metabolism, a heightened self-awareness, and feeling of calm. Among the main trait effects (changes that endure over time) are improved concentration, empathy, perceptual acuity, a drop in anxiety and stress symptoms, and more effective performance in a broad range of domains from sports and academic test taking to creativity (p. 31).

Whether their subsequent effects are short- or long-term, contemplative practices have been proven to significantly lower anxiety and stress levels. Thus, students maintain focus and orient attention, and process information more quickly and accurately (Shapiro, Brown, \& Astin, 2008). When practiced and sustained over time, these methods improve the student's overall college experience through cognitive and academic performance, management of academic stress, and a greater sense of well-being (Shapiro, Brown, \& Astin, 2008; Hart, 2004).

Across research studies, students who engaged in contemplative pedagogy frequently commented on the personal benefits they received, including improved academic performance and reduced stress levels. These practices also improve the community at large and the relationships between its members. As Hayes (2004) notes:

My students over the past two years have talked about the way these mindfulness exercises help to foster an atmosphere of respect. They often note how these practices have effectively brought the class together as a whole. When courses actively create a respectful environment, students learn to listen, write, 
and argue persuasively from a position of civility, which helps them to become principled citizens. Perhaps most significantly, contemplative practice fosters development of what Martin Buber called "I-Thou" relationships, where other people, events, and things are treated as subjects and not merely as objects for use or enjoyment. Jon Kabat-Zinn remarked during the conference that most of us live, most of the time, in a narrow band of being where we are surrounded by "I," "me," and "mine." We suffer from this narrow focus. How, he asked, can we get more real? As teachers, how can we ignite passion in our students for this kind of presence, this "be-ing" in their own lives? This is precisely the work of contemplative pedagogy: it is about waking up and being present to our lives -here and now (p. 9).

Teachers also receive significant benefits through contemplative pedagogy. The practice takes them out of their specialties and research activities, and allows them to refocus their attention on their students and teaching practice. This mental pause provides a critical reflective period during which the educator may question the implications of their research, what they're studying, and their teaching. When the practice is sustained by the teacher, contemplative pedagogy promotes compassion, empathy, and deeper connections with his or her students. The role of the educator becomes enhanced, not merely as a "content provider" but as a mentor who can provide academic content in a more personal and impactful manner.

Due to these benefits, contemplative pedagogy is gaining nationwide attention. A growing number of leading colleges and universities -including Bowdoin College, the University of Virginia, the University of Michigan, and Bryn Mawr College- have adopted contemplative pedagogy to support their undergraduates' and faculty members' academic and personal success. In addition to college-led initiatives, several national organizations promote contemplative practices by offering online literature, training sessions, and additional forms of support for educators. For example, since 1997 the Center for Contemplative Mind in Society, in collaboration with the American Council of Learned Societies, has awarded approximately 150 fellowships to professors in 100 institutions so they may develop curricula that integrates contemplative practices into classroom teaching (The Center for Contemplative Mind in Society [CCMS], 2015).

\section{Contemplative Pedagogy: Select Practices}

The following are examples of ways of incorporating mindfulness and contemplative practice into the classroom.

\section{Journaling}

Journaling can occur at any point during a class session. When performed before the session begins, students empty their minds of distracting thoughts. They may also use the time to develop questions and insights before class begins. If journaling is performed as a brief pause during the session, students may reflect on the class thus far, list questions 
and contributions they wish to give, and/or write any personal thoughts that are causing stress or anxiety. When performed at end of class, journaling prompts students to reflect on the class session, summarize key points, and create a schedule for their upcoming week. To begin this activity, students are asked to sit upright and take a series of slow, deep breaths for three minutes. They are told to relax their bodies, close their eyes, and feel the gentle pull of gravity in their seated position. This process centers the individual. Once they feel centered, students spend five minutes writing down whatever is on their minds in a "stream of consciousness." The teacher may suggest questions or topics: What happened during your commute to class? What was said last night between you and your partner or friend? How are you feeling about an upcoming exam?

The goal is to empty the mind of these stressors by releasing them onto paper. As students empty their minds of these worries and see their stress on paper, they will more fully understand what really matters and where they are emotionally. Journaling visualizes one's stress rather than keeping it as an abstract, fearful concept. It's not uncommon for a mind full of abstract ideas to waste emotional energy trying to organize them throughout the day, and this creates unnecessary distraction, confusion, anxiety, and stress.

\section{Beholding}

Beholding exercises enhance -and may even alter- one of the primary ways through which we engage with the world: sight (CCMS, 2015). In its most basic form, beholding asks participants to prolong their attentiveness on a single object. For students, this slow and deliberate concentration hones the ability to focus during extended periods, elevates awareness and perception, increases sensitivity, and instills a greater feeling of presence. Beholding illustrates the idea that our immediate, hurried perceptions can be superficial and possibly erroneous. In taking the necessary time to carefully and thoroughly examine a subject, students are able to fully comprehend the subject at hand and develop advanced insights and ideas, thus achieving optimal learning.

To perform this exercise, students stand in front of an artwork, a plant, or anything else that is visually calming and appealing for them. They are asked to look at it directly, confront it "face-to-face," and if possible, hold it in their hands and try to really gauge and feel its grand scale or be drawn into the intimacy of its smallness. The teacher guides the students by asking them to pay attention to every detail and let their eyes "caress" the shape and surface. Students are posed questions to heighten observation and a sense of wonder: What do you see? What do you notice as you linger with the object? What moves you? How are you feeling right now, as you deepen your observation? Beholding works in direct contrast to the usual two-second walk-by experience that characterizes our daily lives (CCMS 2015). Beholding asks participants to dissect and analyze what they're seeing. It creates a deeper form of encounter while teaching the skills of mindfulness and focus in our multitasking, distracted, stressed-out world.

It is important that students refrain from performing research on the chosen object before or during the activity. This allows them to form their own, unbiased observations and associations with the object -and a more sensitive understanding of themselves through their own thoughts and feelings. Beholding can lead to particularly rewarding results if students return to the same object each week; through repeated viewing, the students' 
wandering attention is brought back to the same object again and again. Their initial expression of apathy for the object may suddenly turn into feelings of reverence and love. Although the object does not change, the participants frequently notice changes in themselves (CCMS, 2015).

\section{Guided Meditation on a Raisin}

Though seemingly outlandish, this exercise is one of the most effective to develop a more focused, mindful, and less stressed self. In a quiet space, the student silently contemplates a single raisin (or other fruit) for a full five minutes. Each student holds one in his or her hand and looks at it.

To guide the contemplation, the facilitator poses a series of questions and actions: "What do you notice?", "Take a closer look to see, touch, and smell the unique form, texture, and aroma", and "Form your ideas slowly and gradually." Finally, each student is asked to taste, chew, and swallow their raisin. During this slow, deliberate process, the facilitator encourages students to, "Focus on this one simple act, moment-by-moment" and "The greater attention you give, the more your focus will strengthen over time for a deeper self-awareness and enhanced learning experience." This meditation exercise, when performed with regularity, allows students to become more accustomed to slowing down and focusing on details, thereby elevating their quality of life while decreasing their stress. The resultant improvement of the student's academic performance is direct; the ability to sustain focus and closely examine subject matter aids comprehension and strengthens cognitive development.

Another form of this exercise asks students to look at a familiar place or person as if it were the very first time. They mindfully note ever detail they see so that their consciousness, attention span, and ability to focus on one element strengthens. Paired with journaling, this can be an intense and powerful exercise.

\section{Silent Sittings Before and After Work}

Gurleen Grenwal, associate professor and teacher of mindfulness in the University of South Florida describes this contemplative practice well. She states:

In each class we have silent sittings, quieting the mind via the breath, with basic instructions to observe the flow of thoughts/reactions from a nonjudgmental space - a practice crucial in developing acceptance, tolerance, and compassion for oneself and others. I like to begin class with five to ten minutes of mindfulness that very gradually increases as the semester proceeds (as cited in Barbezat \& Bush, 2014).

To perform this meditation, students simply sit in their chairs with their spines erect and their bodies relaxed. Eyes are then closed. Using a Tibetan singing bowl or similar sound -which can easily be found through various phone apps-students follow the ebbing of the sound as it dies out into a prolonged silence. The facilitator tells students, "As you rest in that silence, thoughts may enter your mind. Simply observe them, along with any bodily sensations that occur. If your mind returns to distracting thoughts, deliberately and mind- 
fully focus on your breath and let go of the thoughts, as if they were clouds floating by on a sunny day." The participants' slow, deep breathing is their anchor during the period of silent rest. The meditation ends when the student's breathing and heart rate are decreased, and his or her body feels fully relaxed. Once this state is reached, the student may open his or her eyes slowly, and take one final deep inhale and exhale.

\section{Conclusion}

Across the U.S., college campuses are witnessing escalating numbers of undergraduates experiencing emotional challenges. Students face an increasingly unstable and uncertain world due to rising political discord, terrorism, tensions between world powers, and more. Additional factors are impacting college students' emotional health. Research shows excessive engagement with digital technology -such as the high frequency of electronic messaging- negatively affects users' sense of well-being. Over time, these stresses weaken students' cognitive, emotional, and physical health, and contribute to the record numbers of undergraduates seeking services for mental health issues. It is incumbent upon U.S. higher education to increase support systems that target this growing crisis.

Contemplative pedagogy is one form of support that is being adopted by U.S. higher education. This is due in part to its practical approach that can be easily and effectively provided to all students. Through sustained practice, these pedagogical methods focus attention, diminish stress and anxiety, improve mental and physical health, strengthen memory, and increase creativity. These, in turn, can improve cognitive development while elevating one's quality of life. As Haynes (2004) notes, when people perform such exercises they "develop new techniques of awareness; they learn to refine their perceptual and observational skills; and they are encouraged to take chances and to foster attitudes such as curiosity and wonder rather than cynicism about the world in which we live" (pp. 8-9). Our hyper-accelerated and all-consuming world requires us to relearn how to slow down and become more present. In doing so, we will have a significantly better quality of life, feel more connected with those around us, and gain a deeper understanding for what truly matters most in our lives.

\section{References}

American College Health Association. (2009). American College Health Association-National College Health Assessment II: Reference Group Executive Summary Fall 2009. Linthicum, MD: American College Health Association. Retrieved from http://www.acha-ncha.org/ docs/ACHA-NCHA_reference_group_executivesummary_fall2009.pdf

American College Health Association. (2017). American College Health Association-National College Health Assessment II: Reference Group Undergraduate Executive Summary Spring 2017. Hanover, MD: American College Health Association. Retrieved from http://www. acha-ncha.org/docs/NCHA-II_SPRING_2017_UNDERGRADUATE_REFERENCE_ GROUP_EXECUTIVE_SUMMARY.pdf 
American Psychological Association. (2017a). Stress in America: Coping with Change. Stress in America Survey. Retrieved from https://www.apa.org/news/press/releases/stress/2016/ coping-with-change.pdf

American Psychological Association. (2017b). Stress in America: The State of Our Nation. Retrieved from http://www.apa.org/news/press/releases/stress/2017/state-nation.pdf

Anderson, M. (2015, October 29). Technology device ownership: 2015. Pew Research Center. Retrieved from http:/www.pewinternet.org/2015/10/29/technology-device-ownership-2015/

Anderson, R., Birnie, A.K., Koblesky, N.K., Romig-Martin, S.A., \& Radley, J.J. (2014). Adrenocortical status predicts the degree of age-related deficits in prefrontal structural plasticity and working memory. Journal of Neuroscience 18, 34(25). Retrieved from http:// www.jneurosci.org/content/34/25/8387

Barbezat, D.P. \& Bush, M. (2014). Contemplative practices in higher education: Powerful methods to transform teaching and learning. San Francisco: Jossey-Bass.

Beresin, G., Schlozman, S., \& Abdu-Glass, E. (2017). The college mental health crisis: A call for cultural change-Part 1. Massachusetts General Hospital Clay Center. Retrieve from https://www.mghclaycenter.org/parenting-concerns/college-suicide/

Berkman, L. \& Syme, S.L. (1979). Social networks, host resistance, and mortality: A nineyear follow-up study of Almeda County residents. American Journal of Epidemiology, 109(2), 186-204.

Boddy, J. (2017). Feeling way more stressed out? You're not alone. National Public Radio. Retrieved from https://www.npr.org/sections/health-shots/2017/02/15/515366975/ feeling-way-more-stressed-out-youre-not-alone

Brody, J. (2017, June 12). Social interaction is critical for mental and physical health. The New York Times. Retrieved from https://www.nytimes.com/2017/06/12/well/live/havingfriends-is-good-for-you.html

Brown, J. (2016, October 1). A growing challenge: More students seeking help -a look behind the numbers. Boston University Today. Retrieved from http://www.bu.edu/today/2016/ mental-health-college-students/

Campbell, S. W., \& Park, Y. J. (2008). Social implications of mobile telephony: The rise of personal communication society. Sociology Compass, 2(2), 371-387.

Carnevale, A., Smith, N., Melton, M., \& Price, E.W. (2015). Learning while earning: The new normal. Georgetown University Center on Education and the Workforce. Retrieved from https://cew.georgetown.edu/wp-content/uploads/Working-Learners-Report.pdf

Center for Collegiate Mental Health. (2017, January). 2016 Annual Report. University Park, PA: Pennsylvania State University. Retrieved from https://sites.psu.edu/ccmh/ files/2017/01/2016-Annual-Report-FINAL_2016_01_09-1gc2hj6.pdf

Center for Collegiate Mental Health. (2018, January). 2017 Annual Report. University Park, PA: Pennsylvania State University. Retrieved from https://sites.psu.edu/ccmh/files/ 2018/01/2017_CCMH_Report-1r3iri4.pdf

The Center for Contemplative Mind in Society. (2015). Retrieved from http://www.con templativemind.org/about

Center for Teaching. (2018). Mindfulness in the classroom. Vanderbilt University. Retrieved from https://s3.amazonaws.com/vu-wp0/wp-content/uploads/sites/59/2010/ 06/02133835/mindfulness.pdf 
Cherry, K. (2017, September 27). Multitasking: Bad for your productivity and brain health. Very Well. Retrieved from https://www.verywell.com/multitasking-2795003

Cohen, M. (2018). Student guide to surviving stress and anxiety in college and beyond. Learn Psychology. Retrieved from https://www.learnpsychology.org/student-stress-anxiety-guide/

Darling-Hammond, L. (2010). The flat world and education: How America's commitment to equity will determine our future. New York: Teachers College Press.

Davey, G.C.L. (2012, June 19). The psychological effects of tv news. Psychology Today. Retrieved from https://www.psychologytoday.com/blog/why-we-worry/201206/thepsychological-effects-tv-news

Deckro, G. R., Ballinger, K. M., Hoyt, M., Wilcher, M., Dusek, J., Myers, P., Greenberg, B., Rosenthal, D.S., \& Benson, H. (2002). The evaluation of a mind/body intervention to reduce psychological distress and perceived stress in college students. Journal of American College Health, 50, 281-287.

Der Hovanesian, M. (2003). Zen and the art of corporate productivity. Bloomberg. Retrieved from https:/www.bloomberg.com/news/articles/2003-07-27/zen-and-the-artof-corporate-productivity

Eagan, K., Stolzenberg, E. B., Ramirez, J. J., Aragon, M. C., Suchard, M. R., \& Hurtado, S. (2014). The American freshman: National norms fall 2014. Los Angeles: Higher Education Research Institute, University of California, Los Angeles.

Evans, L. (2014, September 24). You aren't imagining it: Email is making you more stressed out. Fast Company. Retrieved from https://www.fastcompany.com/3036061/the-futureof-work/you-arent-imagining-it-email-is-making-you-more-stressed-out

Goleman, D. (2006). Social intelligence: The new science of human relationships. New York: Bantam Books.

Greenberg, M. (2012). How to prevent stress from shrinking your brain. Psychology Today. Retrieved from https://www.psychologytoday.com/blog/the-mindful-self-express/ 201208/how-prevent-stress-shrinking-your-brain

Halonen, L. (2014, May). Why do you find it so hard to not multitask? Hint: Successful multitasking tricks your brain to release happy hormones. Psychology Today. Retrieved from https://www.psychologytoday.com/blog/the-path-passionate-happiness/201405/ why-do-you-find-it-so-hard-not-multitask

Hampton, K., Rainie, L., Lu, W., Shin, I., \& Purcell, K. (2015, January 15). Psychological stress and social media use. Pew Research Center. Retrieved from http://www.pewinternet. org/2015/01/15/psychological-stress-and-social-media-use-2/

Hart, T. (2003). The secret spiritual world of children. San Francisco, CA: New World Library. Hart, T. (2004, January). Opening the contemplative mind in the classroom. Journal of Transformative Education, (2)1. Retrieved from http://sites.middlebury.edu/mindfulness/ files/2016/03/jj2_Hart-2004-Opening-the-Contemplative-Mind-in-the-Classroom.pdf

Haynes, D. (2004). Contemplative practice and the education of the whole person. ARTS: The Arts in Religious and Theological Studies, 16, 8-10. Retrieved from http://deborahjhaynes. com/images/uploads/pdfs/Education_of_the_Whole_Person.pdf

Holman, E.A., Garfin, D.R., \& Silver, R.C. (2014). Media's role in broadcasting acute stress following the Boston Marathon bombings. Proceedings of the National Academy of Sciences, 111(1), 93-98. 
IvyWise. (2018). Admissions statistics. Retrieved from https://www.ivywise.com/ivywiseknowledgebase/admission-statistics/

Jamrisko, M. \& Kolet, I. (2014, August 18). College tuition costs soar: Chart of the day. Bloomberg. Retrieved from http://www.bloomberg.com/news/articles/2014-08-18/ college-tuition-costs-soar-chart-of-the-day

Jaret, P. (2015, October 20). The surprising benefits of stress: A UC Berkeley researcher is discovering the differences between good and bad stress. Greater Good Science Center at University of California, Berkley. Retrieved from https://greatergood.berkeley.edu/article/ item/the_surprising_benefits_of_stress

Kane, L. (2016, January 12). Student loan debt in the US has topped $\$ 1.3$ trillion. Business Insider. Retrieved from http://www.businessinsider.com/student-loan-debt-state-ofthe-union-2016-1

Krauss Whitbourne, S. (2013, October). Is texting stressing you out? Keep the social strains of social messaging from getting to you with 5 easy tips. Psychology Today. Retrieved from https://www.psychologytoday.com/blog/fulfillment-any-age/201310/is-textingstressing-you-out

Levitin, D. (2015). Why the modern world is bad for your brain. The Guardian. Retrieved from: https://www.theguardian.com/science/2015/jan/18/modern-world-bad-for-braindaniel-j-levitin-organized-mind-information-overload

Lewis, R. (2017). Suicide rate for teen girls hits 40-year high. Time. Retrieved from http:// time.com/4887282/teen-suicide-rate-cdc/

Mojtabai, R., Olfson, M., \& Han, B. (2016, November). National trends in the prevalence and treatment of depression in adolescents and young adults. Pediatrics. Retrieved from http://pediatrics.aappublications.org/content/early/2016/11/10/peds.2016-1878

Morbidity and Mortality Weekly Report. (2017). QuickStats: Suicide rates for teens aged 1519 years, by sex - United States, 1975-2015. (CDCP Publication No. 66). Atlanta, GA: U.S. Government Printing Office. Retrieved from https://www.cdc.gov/mmwr/volumes/66/ wr/mm6630a6.htm\#suggestedcitation

National Alliance on Mental Illness and The Jed Foundation. (2016). Starting the conversation: College and your mental health. Retrieved from https://nami.org/collegeguide/ download

National Center for Injury Prevention and Control. (2017). Suicide: Facts at a glance 2015. (CDCP Publication). Atlanta, GA: U.S. Government Printing Office. Retrieved from https://www.cdc.gov/violenceprevention/pdf/suicide-datasheet-a.pdf

Newport, C. (2016). Deep work: Rules for focused success in a distracted world. New York: Grand Central Publishing. Retrieved from http://www.achcoop.ca/Deep\%20 Work/\#calibre_link-32

Novotney, A. (2014). Students under pressure. Monitor on Psychology, 45(8), 36.

Ophir, E., Nass, C., \& Wagner, A. D. (2009). Cognitive control in media multitaskers. Proceedings of: The National Academy of Sciences for the United States of America. Retrieved from http://www.pnas.org/content/106/37/15583

Orlofsky, S. (2016, May 13). U.S. workers spend 6.3 hours a day checking email: Survey. The Huffington Post. Retrieved from http://www.huffingtonpost.com/entry/check-workemail-hours-survey_us_55ddd168e4b0a40aa3ace672 
Paul, A. M. (2013, May 3). You'll never learn! Students can't resist multitasking, and it's impairing their memory. Slate. Retrieved from http://www.slate.com/articles/health_and_ science/science/2013/05/multitasking_while_studying_divided_attention_and_techno logical_gadgets.html

Radicati, S. (Ed.). (2011). Email statistics report, 2011-2015. The Radicati Group, Inc. Retrieved from http://www.radicati.com/wp/wp-content/uploads/2011/05/Email-StatisticsReport-2011-2015-Executive-Summary.pdf

Radicati, S. (Ed.) (2014). Email Statistics Report, 2014-2018. The Radicati Group, Inc. Retrieved from http://www.radicati.com/wp/wp-content/uploads/2014/01/Email-StatisticsReport-2014-2018-Executive-Summary.pdf

Rainie, L. \& Keeter, S. (2006, April). Americans and their cell phones. Pew Research Center. Retrieved from http://www.pewinternet.org/files/old-media//Files/Reports/2006/PIP_ Cell_phone_study.pdf.pdf

Rainie, L. \& Perrin, A. (2017, June). 10 facts about smartphones as the iPhone turns 10. Pew Research Center. Retrieved from http://www.pewresearch.org/fact-tank/2017/06/28/10facts-about-smartphones/

Reid, D.J. \& Reid, F.J.M. (2007). Text or talk? Social anxiety, loneliness, and divergent preferences for cell phone use. CyberPsychology \& Behavior, 10(3), 424-435. Retrieved from https://www.liebertpub.com/doi/pdf/10.1089/cpb.2006.9936

Sanders, R. (2013). Researchers find out why some stress is good for you. University of California, Berkley News. Retrieved from http://news.berkeley.edu/2013/04/16/researchersfind-out-why-some-stress-is-good-for-you/

Seppälä, E. (2014). Connectedness \& health: The science of social connection. Retrieved from https://emmaseppala.com/connect-thrive-infographic/

Seppälä, E. (2016). The Happiness Track: How to Apply the Science of Happiness to Accelerate Your Success. San Francisco: HarperOne.

Shanker, D. (2017). Americans just broke the psychologists' stress record. Bloomberg. Retrieved from https://www.bloomberg.com/news/articles/2017-02-15/americans-justbroke-the-psychologists-stress-record

Shapiro, D, Dundar, A., Huie, F., Wakhungu, P.K., Yuan, X., Nathan, A. \& Bhimdiwali, A. (2017, December). Completing college: A national view of student completion rates - Fall 2011 Cohort. Herndon, VA: National Student Clearinghouse Research Center.

Shapiro, D., Dundar, A., Wakhungu, P.K., Yuan, X., Nathan, A, \& Hwang, Y. (2016, September). Time to degree: A national view of the time enrolled and elapsed for associate and bachelor's degree earners. Herndon, VA: National Student Clearinghouse Research Center.

Shaprio, S. L., Brown, K. W., \& Astin, J. A. (2008). Toward the integration of meditation into higher education: A review of research. Center for Contemplative Mind in Society. Retrieved from http://www.contemplativemind.org/files/MedandHigherEd.pdf

Smith, A. (2011, September 19). Americans and text messaging. Pew Research Center. Retrieved from http://www.pewinternet.org/2011/09/19/americans-and-text-messaging/

Sparshott, J. (2015, May 8). Congratulations, Class of 2015. You're the most indebted ever (for now). The Wall Street Journal. Retrieved from http://blogs.wsj.com/economics/ 2015/05/08/congratulations-class-of-2015-youre-the-most-indebted-ever-for-now/ 
Straumsheim, C. (2016, March 2). Read and unread. Inside Higher Ed. Retrieved from https://www.insidehighered.com/news/2016/03/02/study-explores-impact-social-mediatexting-email-use

Towbes, L. C., \& Cohen, L. H. (1996). Chronic stress in the lives of college students: Scale development and prospective prediction of distress. Journal of Youth and Adolescence, 25, 199-217.

Turkle, S. (2016). Reclaiming conversation: The power of talk in a digital age. New York: Penguin Books.

U.S. Department of Education, National Center for Education Statistics. (2017). The Condition of Education 2017. Retrieved from https://nces.ed.gov/fastfacts/display.asp?id=569

Welch, A. (2016, March 10). Why so many Americans are feeling more stressed out. CBS News. Retrieved from http://www.cbsnews.com/news/stress-levels-in-the-u-s-continueto-increase/

Whitty, M.T. \& Young, G. (2016). Cyberspace: The Study of Individuals, Society and Digital Technologies. Hoboken, NJ: Wiley Publishing.

Winerman, L. (2017, September). By the numbers: Stress on campus. American Psychological Association, (48)8, 88.

Resumen: En los EE. UU., los campus universitarios son testigos de un número cada vez mayor de graduados con problemas emocionales. Los estudiantes se enfrentan a un mundo cada vez más inestable e incierto debido a la creciente discordia política, el terrorismo, las tensiones entre las potencias mundiales, y más. Factores adicionales están afectando aún más la salud emocional de los estudiantes universitarios. Las investigaciones muestran que el compromiso excesivo con la tecnología digital -como la alta frecuencia de los mensajes electrónicos- afecta negativamente la sensación de bienestar de los usuarios. Los volúmenes extremos de textos y tweets enviados y recibidos evitan que la gente se sienta "desconectada" y presente durante cualquier situación dada; la multitarea se ha convertido en un comportamiento normativo, tanto para profesionales como para estudiantes. Con el tiempo, estas tensiones debilitan el pensamiento cognitivo y emocional, así como la salud física, y contribuyen al número récord de estudiantes de pregrado que buscan servicios por problemas de salud mental. En respuesta a toda esta problemática, muchas universidades de EE. UU. están adoptando técnicas pedagógicas dirigidas a la salud mental de los estudiantes. Conocida como "Pedagogía Contemplativa", estos métodos simples pero altamente efectivos apuntan a disminuir los niveles de estrés, mejorar la sensación de bienestar y aumentar la "atención plena" para que los estudiantes se sientan más presentes en el aula. Al adoptar estos métodos pedagógicos, el desarrollo emocional y cognitivo de los estudiantes se fortalece. Este documento tiene como objetivo proporcionar a los educadores una conciencia de los crecientes desafíos emocionales experimentado por estudiantes universitarios y también proporciona a los educadores métodos prácticos para incorporar técnicas de pedagogía contemplativa en sus aulas para el éxito académico y personal de los estudiantes. 
Palabras clave: Pedagogía contemplativa - desarrollo del estudiante - pedagogía - enseñanza y aprendizaje - bienestar - manejo del estrés.

Resumo: Nos Estados Unidos, os campi universitários estão testemunhando um número crescente de graduados com problemas emocionais. Os estudantes enfrentam um mundo cada vez mais instável e incerto devido à crescente discórdia política, terrorismo, tensões entre as potências mundiais e muito mais. Fatores adicionais estão afetando ainda mais a saúde emocional dos estudantes universitários. Pesquisas mostram que o comprometimento excessivo com a tecnologia digital, como a alta frequência de mensagens eletrônicas, afeta negativamente a sensação de bem-estar dos usuários. Os volumes extremos de textos e tweets enviados e recebidos impedem que as pessoas se sintam "desconectadas" e presentes durante qualquer situação; A multitarefa tornou-se um comportamento normativo, tanto para profissionais quanto para estudantes. Com o tempo, essas tensões enfraquecem o pensamento cognitivo e emocional, bem como a saúde física, e contribuem para o número recorde de estudantes de graduação que procuram serviços para problemas de saúde mental. Em resposta a toda essa problemática, muitas universidades de EE. UU, eles estão adotando técnicas pedagógicas voltadas para a saúde mental dos estudantes. Conhecida como "Pedagogia Contemplativa", esses métodos simples, mas altamente eficazes, visam reduzir os níveis de estresse, melhorar a sensação de bem-estar e aumentar a "atenção plena" para que os alunos se sintam mais presentes na sala de aula. Ao adotar esses métodos pedagógicos, o desenvolvimento emocional e cognitivo dos estudantes é fortalecido. Este documento visa proporcionar aos educadores uma consciência dos desafios emocionais crescentes experimentados por estudantes universitários e também fornece educadores com métodos práticos para incorporar técnicas de pedagogia contemplativa em suas salas de aula para o sucesso acadêmico e pessoal dos alunos.

Palavras chave: Pedagogia contemplativa - desenvolvimento do aluno - pedagogia - ensino e aprendizagem - bem-estar - gestão do stress.

[Las traducciones de los abstracts fueron supervisadas por el autor de cada artículo] 


\section{Preconceptions of the Ideal: Ethnic and Physical Diversity Fashion}

Thomas Werner *

\begin{abstract}
As we see a rise in the conversation regarding diversity across social media, the fashion industry is simultaneously driving a discourse around inclusion and the preconceived ideas of the "ideal" and body diversity. What has been a predominantly Western European and American response will be examined via current advertising campaigns and runway shows hosted by established fashion companies, (e.g. Gucci, Max Mara, Bottega Veneta, Aerie, Rio Uribe, and others) providing context for the socio-cultural evolution within the fashion industry.
\end{abstract}

Keywords: Diversity - Fashion Campaigns - Cultural - Cross-Cultural - Advertising Campaigns - Media - Commercial Media - Social Awareness - Mono-ethnic.

[Abstracts in spanish and portuguese on page 193]

(*) Thomas Werner is the author of the book The Fashion Image for Bloomsbury Press, London, and an Editor at Large for IRKmagazine, a Paris based fashion and culture magazine and web site. An Assistant Professor and past Photography Program Director at Parsons School of Design in New York, Thomas currently lectures internationally on topics of photography, fashion, education, and contemporary professional practices. He is also the former owner of Thomas Werner Gallery in Manhattan's Chelsea Art District, and recently lead a team developing a media and literacy web site and resource center in five languages, Spanish, French, Russian, Arabic and English for the United Nations Alliance of Civilizations/UNESCO. Werner has worked with the Department of State on cultural projects in Russia, and been a photography consultant for $\mathrm{COACH}$ and Rodale Publishing, among others. He has been a recurrent instructor at the United Nations Education First Summer School, and is presenting workshops on effective message development and visual communication on an international basis.

Over the last 12 years his research work has been Russia centric spending an average of 40 days a year there partnering with 32 cultural, educational, and governmental organizations to develop projects in 29 cities. The focus has been the introduction of contemporary education methodologies, and the development of creative cultures within the country. Russian partners have included; The State Hermitage Museum, the National Center of Contemporary Art, Perm Regional Government, The Moscow Biennale for Young Art, National Centre of Photography for the Russian Federation, The Central State Archive of Film, Photographic and Phonographic Documents, The Pro Arte Foundation, and others. He has curated exhibitions in the United States and abroad, including seven co-curated 
exhibitions at the State Hermitage Museum in Saint Petersburg, Russia. His private collection of Russian photographs and artifacts, have been exhibited internationally.

\section{Introduction}

Historically, fashion design -and the imagery that defines it- has shown us where our boundaries lie and how we alternately seek to embrace or break them. This applies not only to the garments we wear, but also to the manner in which fashion addresses the social and cultural norms of the era or country in which they are designed, presented, and advertised. As noted by Contributing Editor to Vogue Camilla Nickerson, in the motion picture In Vogue, "Fashion to me is a reflection of culture. It is not just about whether everyone's wearing a trench coat, it's a report on the world at large" (as cite in Bailey\& Barbato, 2012). According to the illustrations in the Western European and American fashion magazines and the runways prior to 1959, the world of fashion was solely Caucasian. Additionally, although the body types shown in fashion have ranged dramatically from the early $1900 \mathrm{~s}$ to present, a broader inclusion of body diversity is new to both the Western European and American fashion industries.

The recent study "Comparative Analysis of Media's Portrayal on Ethnicity and Diversity for Fashion Magazine Covers" held at Illinois Sate University investigated how fashion magazine covers portray American beauty ideals with regards to ethnic diversity and thinness in fashion magazines. Content analysis was conducted using 60 covers collected from American Vogue and 60 covers from Gentleman's Quarterly (GQ) over the past six decades, beginning with February 1957. Results showed that of the 78 female models depicted on the Vogue covers, a mere 5.13 percent were Black, while 94.87 percent of the models were Caucasian. The Gentleman's Quarterly covers featured a total of 63 male models of whom 88.88\% were Caucasian, 9.52 percent African American, and 1.60 percent Latino. A total of 12 female models (6.5\%) portrayed on the Gentleman's Quarterly covers were categorized as Caucasian. Overall, the male models in Gentleman's Quarterly represented more ethnicities than female models in both Vogue and Gentleman's Quarterly combined (Lauf, Willer, Wetzel, Campbell, \& Yu, n.d.).

The study suggests the statistical representation of non-Caucasians in fashion media does not reflect the statistics of the nation's population. When compared to the 2016 U.S. Census estimate that showed 76.9 percent of the US population was represented as Caucasian, 13.3 percent Black or African American, 1.3 percent American Indian, 5.7 percent Asian, and 17.6 percent Hispanic, we see the quantities of minorities underrepresented on the covers of American Vogue and Gentleman's Quarterly. It is important to note the 1960 U.S. Census -the first Census to include forms sent by mail (and therefore more accurate than previous accountings)- found 88.6 percent of the U.S. population was represented as Caucasian, 10.5 percent Black or African American, .3 percent American Indian, .5 percent Asian and Pacific Islander, and 3.2 percent Hispanic (U.S. Census Bureau, 1960). The Illinois State study does not take this variance into account; though when doing so, we still find a large disparity between minority populations and their representation on these magazines' covers. 
Given the Western fashion industry's “ideal” woman has been predominantly Caucasian, it is not surprising that the first non-Caucasian model did not grace the cover a major American fashion magazine until 1959 when Portuguese-American model China Machado appeared on the cover of the February issue of Harper's Bazaar. Interviewed in 2012, Machado spoke of her childhood in Shanghai, "We [non-whites] had no images. We had nothing that told us we were nice-looking. Nothing. So, I didn't think of myself as goodlooking at all. It never occurred to me" (as cited in Hoskins, 2014, p. 129). It wasn't until 1965 that Donyale Luna was featured as the first Black model on the cover of a major American fashion magazine when Harper's Bazaar Editor Nancy White featured an illustration of Luna on the January edition. Luna was quickly offered a one-year contract with the magazine, and in 1965 she was featured in a ground-breaking 6-page spread photographed by Richard Avedon (Arogundade, 2012). This was followed by Luna's appearance as the first black model on cover of British Vogue in March of 1966, and a biographic article in Time Magazine's April $1^{\text {st }}$ issue in 1966. Yet, despite these breakthroughs and the multi-cultural dialog of acceptance being promoted by the counterculture movement -as embodied in Coca Cola's groundbreaking "I'd Like To Teach The World To Sing" television advertising campaign in 1971 that featured ethnically diverse young people from around the world- the fashion runways continued to be dominated by Caucasian models.

The brief but acclaimed exception was in 1973 when "The Battle of Versailles" runway competition pitted five prominent American designers (Halston, Oscar de la Renta, Bill Blass, Anne Klein, and Stephen Burrows) against five of the most internationally esteemed French designers (Yves Saint Laurent, Hubert de Givenchy, Emanuel Ungaro, Pierre Cardin, and Marc Bohan of Christian Dior). This was a ground-breaking event for the American designers who had long been considered "second tier" up until that time; however, the American designers stole the show and left with a new-found respect amongst international fashion industry pundits. The event was particularly notable for the ethnic diversity of the fashion models. The American designers brought thirty-six models with them, eleven of whom were black -a relatively high number at the time. Their appearance on the runway at Versailles was a reflection of what was occurring politically and socially in terms of American race relations at home (Bateman2015).

Though symbolic of the Civil Rights Movement and the effort to create a society that was more inclusive, "The Battle of Versailles" was more spectacle than social change, and the inclusion of minority models post-Versailles remained inconsistent. In August of 1974, Beverly Johnson became the first black model to appear on the cover of American Vogue, with the covers of French Elle, Vogue Italia, and other publications and runways to follow. Throughout the late the 1970s Johnson, Iman, and Pat Cleveland appeared in a number of publications, though they were the exception rather than the rule. Vogue Paris continued to be dominated by Caucasian models until as late as 1988 when Yves Saint Laurent threatened to sever ties with the magazine unless Naomi Campbell was put on its cover (Hoskins, 2014).

The 1990s saw the emergence of hip hop and its influence on fashion and the broader cultural landscape. With his oversized preppy style, designer Tommy Hilfiger's fashions became a fixture in hip hop culture with Black artists like Snoop Dogg, Puffy, L'il Kim, and Usher wearing his clothes, and singer Aaliyah featured in his campaigns. Hilfiger recalls: 
In the late 1980s/early 1990s, my clothes were adopted by the music stars of that time -the rappers. They took the preppy style on board, but exaggerated it by blowing up the logo and wearing their chinos two sizes bigger (...). Snoop Doggy Dog appeared on Saturday Night Live wearing an oversized sweater of mine, again helping create a cult following for my label. I was even mentioned in some of the rappers' songs, which is a great honour for me (as cited in The Irish Times, 2000).

Hip hop "opened the door" for Black rap artists to appear in Hilfiger's advertisements. Black-owned companies, such as Damon John's FUBU (or, "For Us, By Us"), also featured rap music artists including LL Cool J along with minority-centric groups of young people in their campaigns, thus helping to diversify ethnic representation in the fashion design and editorial fields. Kimora Lee Simmons, former wife of rap singer Russell Simmons, has been a leading supporter of diversity on the runway. Of all the Fall 2017 runway shows held in New York, London, Paris or Milan that included at least one non-Caucasian model, both Kimora Lee Simmons and Kayne West's brand "Yeezy" ranked in the top 5 for featuring racial diversity among their models (Safronova, 2017). In another breakthrough for the runway, Max Mara's Fall 2017 runway show featured the model Halima Aden in a hijab, further contributing another step towards diversification.

Despite these advances, there are still challenges in terms of promoting racial diversity in the fashion industry. Many established, progressive brands continue to underrepresent diversity among their runway and/or editorial models. For example, the Italian house Prada did not feature a Black model in its advertising campaigns for 19 years until Malaika Firth was cast in 2013. Before this, the last Black model to be featured in a Prada campaign was Naomi Campbell in 1994, the year Firth was born. Following her appointment in 2009, Céline's Creative Director Phoebe Philo didn't use any Black models in the company's runway shows until Spring/Summer 2014 (Stoppard, 2016).

These brands are not an anomaly. Every season, the fashion blog Jezebel calculates the percentage of Caucasian models -compared to non-Caucasian models-featured on the runways of New York Fashion Week. In Fall of 2013, the statistics listed by Jezebel were: 79.98\% white, $8.08 \%$ Black, $8.1 \%$ Asian, 3.19\% Latina. That same season, the demographics of the four major fashion week runways (New York, London, Milan, and Paris), featured close to 88\% Caucasian models (Padula, 2015). While the statistics for the Fall $2013 \mathrm{New}$ York runways moved closer to the demographics reported in the U.S. 2016 Census, there were still disparities when it came to Black, and particularly Latina, models. Asian models were over-represented when compared to the U.S. 2016 Census, though still substantively underrepresented when viewed as a percentage of the population internationally. Underrepresentation of non-Caucasian populations on the runway increases substantially when all four major fashion centers (New York, Paris, London and Milan) are considered. This underrepresentation is being increasingly addressed. In her article, "Whitewashed Runways: Employment Discrimination in the Fashion Modeling Industry," Vanessa Padula (2015) states: 
Some believe that there are economic reasons behind the industry's discriminatory casting practices. While 'it used to be about fashion,' it has turned into being 'about business.' This argument is based on the idea that models of color are not hired more because 'black don't sell.' The more prevalent argument, however, appears to be that in fashion, race is viewed as any other aesthetic feature, such as hair and eye color. For example, when Alber Elbaz, a designer for Lanvin, presented five black women walking down the runway together as the finale for his show, it was described as 'purely aesthetic' (n.p.).

Fashion models Naomi Campbell and Iman, together with campaigner Bethann Hardison, disagreed with the aesthetic argument for predominantly Caucasian advertising and runways, as they wrote in an open letter to designers in September 2013: "No matter the intention, the result is racism" (as cite in Hoskins, 2014, p. 134).

\section{The 2017 Season on the Runway}

The Fall of 2017 provided substantial improvement in terms of ethnicity on the runway, particularly in the three European fashion centers (Paris, Milan, and London). Each fashion season, theFashionSpot creates theFashionSpot Runway Diversity Report that provides the ethnic breakdown for each designer's runway, as well as the overall numbers for each city and the fashion shows as a whole. Recently, the report (2017) stated:

[For the] Fall 2017 season, we examined 241 shows and 7,035 model castings from New York, London, Paris and Milan. According to our data, more women of color walked the runway than ever before. For all four cities combined, 72.1 percent of the models cast were white and 27.9 percent were women of color. This represents a 2.5-point increase over the 25.4 percent nonwhite models we reported for Spring 2017. For reference, Fall and Spring 2016's runways were 24.7 and 22.4 percent nonwhite, respectively (n.p.).

The report also stated that Paris, London, and Milan all saw their most diverse fashion season ever, with New York still presenting the most diverse runways with 31.5 percent models who were non-Caucasian, just .4 percentage points below its most diverse season in Fall 2016. Moreover, for the first time, every runway show in Manhattan included at least one non-Caucasian model. London was second with 27.5 percent, a 4.9 percent increase over Spring 2017. London was followed by Paris and Milan with 25.9 and 23.8 percent respectively; though lagging in diversity, both cities have seen annual improvements since Spring 2015.

While there are significant inequities in terms of racial diversity, a number of brands are promoting diversity. During Paris Fashion Week in 2016, Balmain stood out as an example of a fashion brand that embraced its global audience as each model was of a different in heritage and ethnicity (Stoppard, 2016). During the Fall 2017 fashion shows, the most progressive designers included Rio Uribe who featured 87 percent models of color on the 
runway, Chromat (77 percent), Kimora Lee Simmons (75 percent -down from 85 percent in Spring 2017), and Kanye West (74 percent -down from 97 percent last season and 100 percent the prior season). Conversely, some designers continue to show predominantly Caucasian models. These designers and houses include Lavin where 15 percent of the models on the runway were non-Caucasian, and at Balenciaga (26 percent). Undercover, Trussardi and Junya Watanabe presented entirely Caucasian shows, while Comme des Garcons, Chocheng and Wuachob each cast just one non-Caucasian model (theFashionSpot, 2017).

The men's wear collections added another dimension of diversity to the runway with older models featured in a number of fashion shows - a still rare occurrence in women's wear (Stoppard, 2016). That said, there were Spring 2016 runways that featured women in their thirties and above. For example, in New York, the fashion house Eckhaus Latta featured art adviser Thea Westreich and television producer Susan Fales-Hill; designer Tracy Reese included artist Susan Cianciolo and 1990s iconic fashion model Coco Mitchell; designer Son Jung Wan featured 1960s "supermodel" Pat Cleveland; and J. Crew's fashion show featured staff, family, and friends that represented a large span of age groups. In Italy, Lauren Hutton modeled for the house Bottega Veneta, yet Parisian designers did not participate in this trend (Tai, 2016). This was a small but important step towards true diversity during fashion week.

\section{The 2017 Season in Advertising Campaigns}

Over the last two years, a number of leading fashion brands have made an effort to diversify the fashion models used in their advertising campaigns -though at times with mixed response. For example, Gucci featured (as part of the brand's 2017 pre-fall campaign) a series of Instagram videos in which it asked Black models, "What does it mean to have soul?". The campaign, titled "Soul Scene," was photographed to look like a late 1960's or early 1970's block party. This was a step forward for Gucci whose past campaigns had featured predominantly Caucasian models. Yet, questions regarding its authenticity were raised by some. As R. Eric Thomas (2017) notes in The New York Times:

While the campaign purports to celebrate black soul, it smacks of performance rather than genuine homage. Is it offensive? Not really. Is it appropriation? Well, there's the rub. It would be if the ads included the culture. Instead, Gucci presents a reverent, painstakingly-recreated facsimile of a culture. More than anything, the campaign is about the look (n.p.).

Several fashion brands have also supported ethnic diversity in their recent advertising campaigns. Designer Brandon Maxwell featured Black model Jourdan Dunn and her son in his Spring/Summer 2018 advertising campaign and has featured diverse models since his brand's first campaign in Fall of 2016. Acne Studios' Fall 2017 campaign -featuring Kordale Lewis and Kaleb Anthony, a gay Black couple, and the gentlemen's four children- was considered by many to be history-making as they became the first Black LGBT 
(Lesbian, Gay, Bisexual, and Transgender) family to represent a "high-fashion" European clothing line (Payne, 2017).

These, and other advertising campaigns, contribute towards the growing diversification of models' ethnicities within the fashion industry. This is suggested by theFashionSpot's 2017 Diversity Report -a review of 187 advertisements and 487 castings- that showed an overall increase in diversity in the advertising campaigns that exceeded the gains on the runway. The study notes 30.4 percent of the models featured in advertising campaigns were nonCaucasian, almost double the 15.3 percent featured in Spring of 2015. This represented the highest total recorded and a 5.9 percent increase over Spring 2017 (Tai, 2017).

\section{Women's Body Diversity}

Ethnicity was not the only area in which the fashion industry expanded models' diversification over the past two seasons; plus-size models increased their presence on the runway -yet seem to have plateaued in terms of advertising campaigns. Valeriya Safrona (2017), writer for The New York Times stated in her article "Diversity, of All Kinds, Is on the Rise at Fashion Shows," thirty plus-size models walked the runways that season, up from sixteen last season and six the season before, though most of the appearances were in New York. Ashley Graham -who is becoming something of a "supermodel," with history-making appearances on the covers of the Sports Illustrated Swimsuit Issue, British Vogue and American Vogue- became the first plus-size model to walk in a Michael Kors show, though she was also the only plus-size model in the show (Safronova, 2017). TheFashionSpot's Diversity Report noted the 2017 fashion season was something of a watershed moment for the fashion industry; yet, in the print advertising domain, plus-size women accounted for just 10 of the 457 model castings -or, 2.2 percent, a 0.1-point dip from the Spring 2017 campaign season. The low number of plus-size castings demonstrates that fashion designers still have a long way to go in terms of inclusion (Tai, 2017).

However, there were positive signs in commercial advertising that went beyond the few, popular models like Ashley Graham. The lingerie and intimate apparel brand Aerie has consistently used models of various races and body types in its print and video advertising. The company's recent advertising campaign featured a diverse group of models (dubbed the “@aerieReal Role Models") including singer/songwriter Rachel Platten, actress Yara Shahidi, gold medal winning gymnast Aly Raisman, and body positive activist Iskra Lawrence. This is a notable example of a fashion company that has placed positive body image at the core of its brand identity. Additional examples of advertising campaigns featuring body diversity include plus-size model Candice Huffine appearing in bikini advertisements for Violeta by Mango, and models Philomena Kwao and 56-year-old Nicola Griffin, joining Ashley Graham in a 2016 campaign for Swimsuitsforall. In addition to being socially responsible, the inclusion of plus-size models is a good business decision for many designers. According to The NPD Group, a New York-based market research company, annual U.S. sales of women's plus-size apparel (sizes 14 and higher) rose by 17 percent to $\$ 20.4$ billion in 2016, from $\$ 17.4$ billion in 2013. During that time, overall apparel sales increased by just 7 percent (The Fashion Law, 2017). 


\section{Men's Body Diversity}

Men faced similar issues regarding physical diversity on the runway and in fashion advertising campaigns. In his article "Expanding the Male Ideal: The Need for Diversity in Men's Fashion Advertisements," Ben Barry (2014) describes the two body types that have dominated men's fashion over the past thirty-five years. Barry's research found that male models in men's magazines depict a relatively uniform hegemonic, muscular body type and that the presence of muscular male models has increased over time in popular men's magazines. However, the idealized male body has evolved in the fashion industry. When designer Hedi Slimane introduced a skinny male silhouette for Dior Homme with great fanfare in 2000, a new male body standard emerged. This slimmer body gained tremendous attention and widespread appeal, thus prompting the Rootstein male mannequin -the fashion industry's "golden standard"- to shrink from a 42-inch chest and 33-inch waist in 1967 to a 35-inch chest and 27-inch waist in 2010. The garment sample size for male models also decreased from an Italian suit size 50 (U.S. 40) in the 1990s to a size 46 (U.S. 36) today (Barry, 2014). This has provided two rather unattainable physical choices for the majority of men. As note earlier, there may be greater age diversity on the men's runways, but this area of the industry lags behind women's wear in terms of diverse physical representation. Overall, there has been minimal dialog regarding ethnic or physical diversity in men's fashion. At this point in time, the conversation surrounding women has yet to expand to men.

\section{Legal Changes}

Concerns regarding the homogeneous, and at times, unhealthy body types represented on the fashion runway have also caught the attention of government officials. In 2017, France passed a law requiring models to provide a doctor's certificate attesting to their overall physical health, with special regard to their age and body mass index (BMI), a measure of weight in relation to height. Employers breaking this law could face fines of up to 75,000 Euros $(\mathfrak{E} 63,500 ; \$ 82,000)$ and up to six months in jail. The French Ministry of Health has stated the aim is to fight eating disorders and inaccessible ideals of beauty (BBC News, 2017). Eleven years earlier, Spain passed a law banning models with a body mass lower than 18; the United Nations recommends a body mass of between 18.5 and 25 for healthy individuals (BBC News, 2006). The year 2006 also saw Italy ban female models with a BMI of less than 18.5. Other legislation enacted by government officials included a minimum age limit of 16 for models and a ban on using cosmetics to achieve an 'anorexic look' with dark shadows under the eyes (McMahon, 2006). In the U.S., The Council of Fashion Designers of America (CFDA) has opted instead for voluntary measures that put the focus on nutritional and emotional counseling. According to CFDA President Diane von Furstenberg, some models have been "red-flagged" and removed from the runway to focus on eating and living well (as cited in Critchell, 2010).

The concerns regarding body representation and good health have not ended on the runway. In October of 2017 France enacted a law that requires all commercial photos that have been digitally altered to make a model's body appear thinner or thicker to bear the 
warning "photographie retouchée" (retouched photograph). Those who do not comply with this law face a fine of at least $\$ 44,000$ USD, or 30 percent of advertising costs. According to Delphine Perez, writing for Le Parisien, Marisol Touraine, France's former health minister, got the ball rolling on the idea of the law and explained, "It is necessary to act on body image in society to avoid the promotion of inaccessible beauty ideals and prevent anorexia among young people" (as cited in Yee, 2017).

One of the problems models face is a lack of legal protection. In most countries, models are considered independent contractors -and this comes with certain implications. In the U.S., each state has a different common law standard for distinguishing independent contractors from employees, and models in the U.S. are still considered independent contractors, having "commission-based contracts" with their agencies. Under Title VII, an employer cannot discriminate against an employee based on religion, sex, national origin, race, or color. Discriminatory practices covered by the statute include: refusing to hire or promote an employee; firing an employee; or segregating or classifying an employee based on any of the attributes listed above. In order for an employee to establish a case of employment discrimination under Title VII, they must provide evidence that the classification was a "motivating factor" in a decision made by their employer that adversely affected them. In the case of fashion models, the model would have to demonstrate that the color of his/her skin motivated the casting director or designer to not hire them.

In this context, it is important to consider the argument that designers and casting directors engage in artistic expression when casting models for their fashion shows and campaigns. In deciding which models to cast, many designers and casting directors strive to captivate the creative vision that inspired the fashion collection. Thus, a model may not be hired because she is not what the designer "aesthetically and artistically" envisioned. Although this First Amendment claim may disparately affect non-Caucasian over Caucasian models, it appears that some courts would agree with protecting this type of artistic expression. The Supreme Court concluded that the motion picture industry is afforded a similar protection under the First Amendment. It is possible many fashion designers use similar reasoning to argue that it is their First Amendment right to cast the models they wish for their fashion shows and/or advertising campaigns (Padula, 2015).

\section{Conclusion}

The increasing demand and necessity for ethnic, age-based, and body diversity on the runway and in advertising is changing the manner in which fashion designers and brands cast and produce fashion shows and advertising campaigns. These changes to the existing fashion system are essential, not only in terms of meeting societal demand, but also to address the promotion of unhealthy body types. In the rapidly changing commercial environment, outdated business practices must evolve to reflect the broader community. Although the 2016 and 2017 runway shows and advertising campaigns showed marked improvements in showcasing diversity, deficiencies remain. However, if the recent fashion seasons suggest an ongoing increase of diversity in the fashion industry -particularly in 
the U.S. and specifically New York- fashion companies and advertising agencies will better reflect the demographics of their potential clientele and the countries in which they reside.

\section{References}

Arogundade, B. (2012, November 11). The tragic tale of Donyale Luna. The Telegraph Media Group. Retrieved from http://fashion.telegraph.co.uk/news-features/TMG9658276/ The-tragic-tale-of-Donyale-Luna.html

BBC News. (2006, September 13). Madrid bans waifs from catwalks. The British Broadcasting Corporation. Retrieved from news.bbc.co.uk/2/hi/ $5341202 . s t m$

BBC News. (2017, May 6). France bans extremely thin models. The British Broadcasting Corporation. Retrieved from http://www.bbc.com/news/world-europe-39821036

Bailey, F. \& Barbato, R. (Producers \& Directors). (2012). In Vogue: The editor's eye [Motion picture]. U.S.A.: Home Box Office Documentary Films.

Barry, B. (2014). Expanding the male ideal: The need for diversity in men's fashion advertisements. Critical Studies in Men's Fashion, 1(3). Bristol, UK: Intellect Ltd.

Bateman, K. (2015, July 2015). Versailles 1973: How one show changed American fashion history. Harper's Bazaar. Retrieved from https://www.harpersbazaar.com/fashion/design ers/a11385/versailles-french-american-fashion-show/

Critchell, S. (2010, February 13). Would older models quell too-skinny debate? The Boston Globe. Retrieved from http://archive.boston.com/lifestyle/fashion/articles/2010/02/10/ would_older_models_quell_too_skinny_debate/

Hoskins, T.E. (2014). Stitched up: The anti-capitalist book of fashion book. London, UK: Pluto Press.

The Irish Times. (2000, August 14). Say goodbye to hip-hop, it's time to get hip. The Irish Times. Retrieve from https://www.irishtimes.com/say-goodbye-to-hip-hop-it-s-timeto-get-hip-1.302650? mode=print\&ot=example.AjaxPageLayout.ot

Lauf, A., Willer, M., Wetzel, S., Campbell, J., Yu, U.J. (PDF document). Comparative analysis of media's portrayal on ethnicity and diversity for fashion magazine covers. Retrieved from https://www.audielauf.com/uploads/4/9/8/5/49858745/2017_aafcs_ethnic_diver sity_and_thinness_in_fashion_magaine_covers_2_.pdf

McMahon, B. (2006, December 2). Catwalk ban on the skinny model in Italy. The Guardian. Retrieved from https://www.theguardian.com/world/2006/dec/03/italy.barbaramcmahon

Padula, V. (2015). Whitewashed runways: Employment discrimination in the fashion modeling industry. Berkeley Journal of African American Law and Policy, 17(1). Retrieved from https://scholarship.law.berkeley.edu/cgi/viewcontent.cgi?article $=1177 \&$ context $=$ bjalp

Payne, T. (2017, August 18). Acne Studios campaign celebrates gay, Black dads. Teen Vogue. Retrieved from https://www.teenvogue.com/story/gay-black-dads-acne-studios-campaign

Safronova, V. (2017, March 16). Diversity, of all kinds, is on the rise at fashion shows. The New York Times. Retrieved from https://www.nytimes.com/2017/03/16/fashion/newyork-fashion-week-2017-diversity.html

Stoppard, L. (2016, July 26). How diversity changed fashion. ELLE. Retrieved from http:// www.elleuk.com/fashion/trends/longform/a31200/diversity-in-fashion/ 
Tai, C. (2016, October 14). Report: The Spring 2017 Runways Were the Most Diverse in History - sort of. theFashionSpot. Retrieved from http://www.thefashionspot.com/runway -news/717823-diversity-report-spring-2017-runways/

Tai, C. (2017, August 29). Diversity report: The Fall 2017 ads were more inclusive than the runways for the first time ever. theFashionSpot. Retrieved from http://www.thefashionspot. com/runway-news/762095-diversity-report-fall-2017-ad-campaigns/

The Fashion Law. (2017, February 28). Is the fashion industry actually starting to celebrate body diversity? The Fashion Law. Retrieved from http://www.thefashionlaw.com/home/ is-the-fashion-industry-actually-starting-to-celebrate-body-diversity

theFashionSpot. (2017, March 16). Report: Fall 2017 was a banner season for runway diversity, especially in New York. TotallyHer Media. Retrieved from http://www.thefashionspot. com/runway-news/740117-runway-diversity-report-fall-2017/

Thomas, R. E. (2017, April 17). Gucci's diversity drag. The New York Times. Retrieved from https://www.nytimes.com/2017/04/17/fashion/gucci-black-models-diversity.html

Lee, B. Y. (2017, October 1). New French law requires label for digitally altered photos of models. Forbes. Retrieved from https://www.forbes.com/sites/brucelee/2017/10/01/ new-french-law-requires-label-for-digitally-altered-photos-of-models/\#19c3ecaele0e

Resumen: A medida que aumenta la discusión con respecto a la diversidad a través de las redes sociales, la industria de la moda está impulsando simultáneamente un discurso sobre la inclusión y las ideas preconcebidas de lo "ideal" y la diversidad corporal. Lo que ha sido una respuesta predominantemente de Europa occidental y Estados Unidos, se examinará a través de campañas de publicidad actuales y desfiles organizados por compañías de moda establecidas (por ejemplo, Gucci, Max Mara, Bottega Veneta, Aerie, Rio Uribe y otros) que proporcionan contexto para la evolución sociocultural en la industria de la moda.

Palabras clave: Diversidad - Campañas de moda - Cultural - Transcultural - Campañas publicitarias - Medios - Medios comerciales - Conciencia social - Monoétnico.

Resumo: À medida que a discussão sobre a diversidade aumenta através das redes sociais, a indústria da moda está dirigindo simultaneamente um discurso sobre inclusão e idéias preconcebidas da diversidade "ideal" e corporal. O que tem sido uma resposta predominantemente da Europa Ocidental e dos Estados Unidos, será examinado por meio de campanhas publicitárias e desfiles organizados por empresas de moda estabelecidas (por exemplo, Gucci, Max Mara, Bottega Veneta, Aerie, Rio Uribe e outras). que fornecem contexto para a evolução sociocultural na indústria da moda.

Palavras-chave: Diversidade - Campanhas de moda - Cultural - Cross-cultural - Campanhas publicitárias - Mídia - Mídia comercial - Consciência social - Mono-étnica.

[Las traducciones de los abstracts fueron supervisadas por el autor de cada artículo] 

Fecha de recepción: abril 2019

Fecha de aceptación: octubre 2019

Versión final: marzo 2020
China: Hyper-Consumerism, Abstract Identity

Marie Genevieve Cyr *

\begin{abstract}
Is the 21st century the Chinese century? Westernization has changed nearly all facets of life in China, except for politics (Wu, 2009). This has created mass-confusion, enthusiasm, rebellion, romanticism, and idealism. The 1990s manufacturing industries continued to dominate the acceleration of consumerism in the $21^{\text {st }}$ century and created, more than ever, a bizarrely giant, abstract world of identity that is self-created and sustained.

This paper examines the politics of abstract desire, hyper-consumerism, and the notion of fantasy in the Chinese fashion industry. Today, hundreds of giant "hyper-malls" found all over China are connected to the distribution of fake "stuff." These commercial emblems have become an integral part of China's visual and social landscape. The marketplace of fake goods using Western brand images (e.g. logos) has grown for centuries to become an abstract superstructure of falsely branded lifestyles and design integrity. The global rise of hyper-consumerism gave China the ultimate opportunity to create a new identity for itself while importing the dream of luxury: The Buying Power.

This paper focuses on abstracting the notion of hyper-consumerism and interrogating the relationship between visual advertisement, its materiality, and its representation in the global marketplace. How does advertising contribute to the production of consumer goods? Can we create a cyclical vision for new materials? How is the value of luxury created, displaced, transformed, and consumed through space and time?
\end{abstract}

Keywords: Luxury - Identity - Exclusivity - Authenticity - Fake - Spirituality - Consumption - Hyper consumption - Malls.

[Abstracts in spanish and portuguese on pages 211-212]

(*) Marie Geneviève Cyr is an Assistant Professor in the BFA Fashion Design program at Parsons School of Design. She has an MA in Visual Culture/Fashion Theory from New York University, a BA in Design and Applied Arts from the Edinburgh College of Art and a degree in Fashion Design from the College Marie-Victorin. Marie Genevieve Cyr was then nominated in 2009, for a Genie Award by the Academy of Canadian Cinema and Television for "Best Costume Design" for the feature film Who is KK Downey? Her work has been exhibited internationally, and focused sculptural forms that examine emotions, history, and materiality. As an educator, Marie Geneviève values the importance of developing research methods that drive innovative cross-disciplinary design practice via $2 \mathrm{D}$ and $3 \mathrm{D}$ investigation. She pushes the students to develop their own personal intellectual expression through unique non-linear approaches. Her research explores the intersections 
between national, rural and urban identities, examining the politics of abstract desire, hyper-realistic landscape, and the notion of fantasy.

\section{Introduction}

Is the $21^{\text {st }}$ Century the Chinese century? Westernization has changed nearly all facets of life in China, except for politics (Wu, 2009). This has created widespread confusion, enthusiasm, rebellion, romanticism, and idealism. The 1990s' manufacturing industries continued to dominate the acceleration of consumerism in the $21^{\text {st }}$ Century. The rise of hyper-consumerism gave China the ultimate opportunity to create a new identity for itself while importing the "dream" of luxury. By transferring Westernized ideas of consumption into visual symbols, production systems, and communication tools, China channeled an idealized fantasy world.

This paper focuses on the notion of hyper-consumerism. By examining the rise of consumerism, quest for individuality, social impact of giant retail spaces, luxury, authenticity, and spirituality, this dissertation challenges the recent changes in the study of fashion and globalization. It underlines recent questions related to economic, social, and cultural logics related to consumption and communication of the constructed significances of fashion.

\section{Context}

Since China opened its doors to the world in 1979, businesses grew rapidly and took a high position into fierce global competitive spaces. In the $20^{\text {th }}$ Century, vast quantities of the Chinese workforce went from being farmers to steel workers to business professionals. The economic growth in China is very significant to all industries. According to its culture and history, China has always encouraged an idea or an object to be spread among people of all classes. Based on this belief, one can argue that popularization of fashion to the masses is a positive cultural advancement for the East.

In the 1980s, the rise of television, print, and other media sources as a means of communication greatly contributed to the commercialization of fashion. The growth of television played a particularly important role in forging a path to the rise of the fashion "copies" or "inspiration." Television programs shown in Japan and Hong Kong provided fashion inspirations for the Chinese to copy. Hong Kong served as both a conduit and a filter of Western fashions and values to China, thus promoting Western television and movie stars to be slowly copied on the mainland. The popularity of fashion inspired by television programs also had an impact on early fashion marketing in China. Private merchants marketed products reflecting the popular television characters even if their merchandise had little connection to the original styles. Wu (2009) notes that the "so-called socialist merchants of the time learned not only how to make money with fashion but also the value of celebrity marketing" (p. 24).

Chinese fashion agents understood very early that importing fashion media icons into the image production of a "dream" was very valuable. As such, members of the music, 
television, and movie scenes have acted as role models and authorities for young consumers. For example, among the most famous musicians were Taiwanese pop singers Deng Lijun and Teresa Teng; the 1980s boy band "Little Tigers"; the 1990s group of male singers known as "Four Heavenly Kings" from Hong Kong; Canto-pop singer Faye Wong; and the South Korean boy band known as "H.O.T." Moving forward, in 2017, Angelica Cheung (2014), Editor-in-Chief of Vogue China and former investment banker, discussed methods of reaching the youth through celebrities on social platforms. Most of the Chinese millennials, due to the one child policy, grew up in wealthier families. As adults, they now "consume for the sake of consuming, without any purpose" (Cheung, 2014). Brands using celebrities as a vehicle to popularize products are reaching fans around the globe and promote these high levels of "blind" hyper-consumption.

Fashion Print media blossomed in the 1980s. Magazines such as Qingnian yidai (the young generation), Zhongguo funv (women of china), Shizhuang (fashion), Xiandai Fuzhuang (modern dress and dress making), and Zhongguo fuzhuang (China garment) led the way to this new industry and high levels of consumption. Many of these magazines included practical patterns and sewing instructions. Some of the television stations in the 1980s also offered long-distance dressmaking lessons to their fashion-hungry audiences. $\mathrm{Wu}$ (2009) notes that "starting in the winter of 1981, a Shanghai television station began airing a popular tailoring program that featured famous master tailors giving lessons on pattern making, the calculation of material usage, and other tailoring techniques" ( $\mathrm{p}$. 26). The Chinese understood decades ago that technology, and the creation of on-air and online education service system, was the future of education. Online education was originally created to accommodate and extend education to people in rural areas but has now evolved into a billion dollars industry attracting millions of online viewers across China. The relationship between fashion design and its manufacturing was symbiotic from its early development. Factories were designing garments and selling them directly to customers and buyers. Several large factories funded fashion exhibitions for their designers and sent their work overseas to international trade shows and competitions ( $\mathrm{Wu}, 2009)$. The creative system, being closely linked to the production system, also gave new opportunities for female factory workers to become "supermodels." Wu (2009) found that "these models modeled only part-time and returned to their factory posts after shows. Their training encompassed not only fitness, body movement, and make up techniques, but also sewing. They were called shizhuang yanyuan (fashion actors)" (Wu, 2009, p. 158). This influenced the implantation of new degree programs across China. Suzhou Institute of Silk Technology established China's first modeling degree program in 1989 and the Chongqing Institute of Engineering, in southwest China, announced in September 2017, an "internet celebrity” program for students who want to be live-streaming stars (Zhen, 2017).

Although the Chinese print media was becoming influential, Western ideas and imagery were still used to promote fashion ideals. For example, in the 1980s, the creative teams of Chinse magazines often used Caucasian models with blond hair and blue eyes. Today, this image is still used in China to promote a certain aesthetic; recently, at The New Century Global Center in Chengdu, a giant monitor above an artificial pool of water screened a Victoria Secret runway show featuring a performance by Taylor Swift. This display both supported and represented the escapism via vacation and a Western concert experience. 


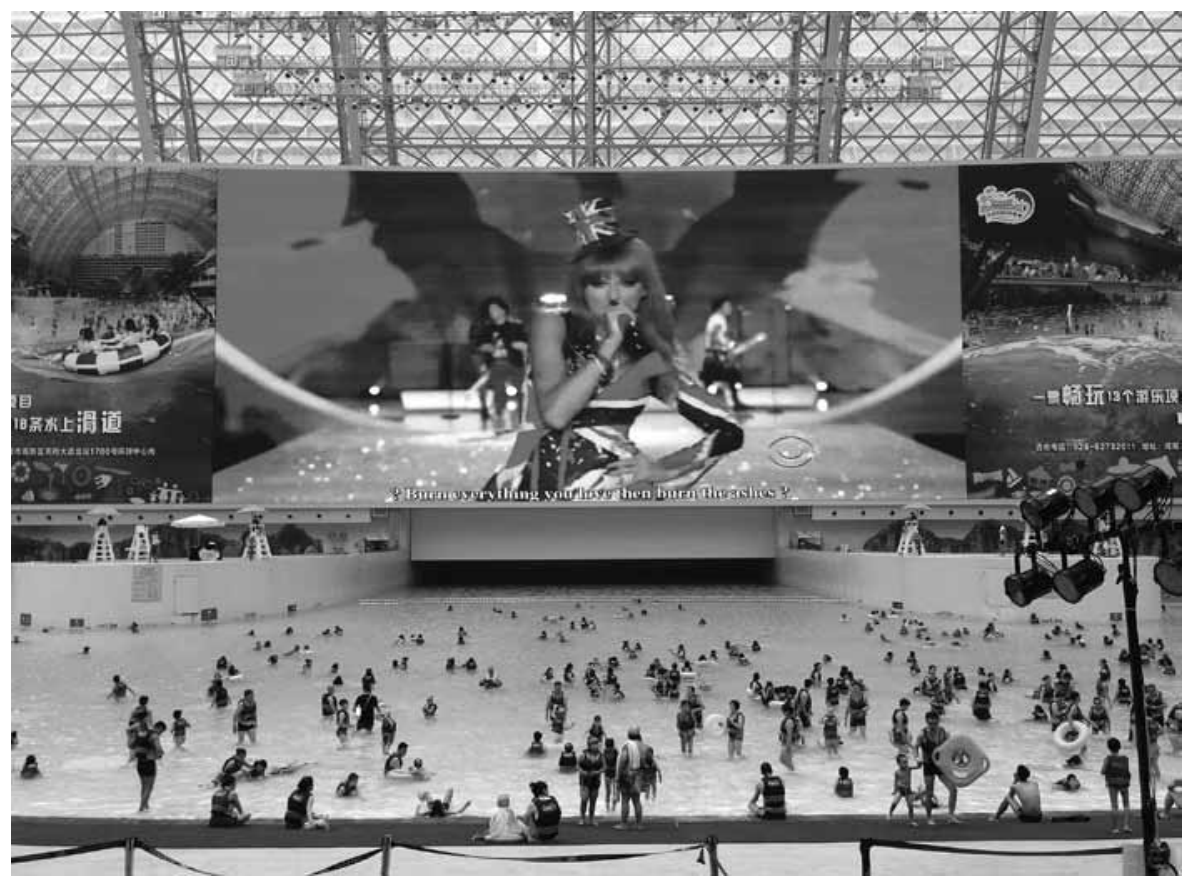

Figure 1. New Global Center, Taylor Swift, August 2016. Photo credits: Joseph Jagos.

In the early 1990s, the traditionally discreet Chinese population suddenly became outspoken through "cultural" t-shirts (Wu, 2009). Printed Chinese characters featured messages such as: "Only my mom is best in this world", "My future is not a dream", and "A peaceful life for all good people". Other t-shirts were more rebellious and conveyed messages such as, "I only follow my feelings" and "Getting rich is all there is." As this fashion trend began to turn into a broader national trend, the government issued "emergency regulations" and formally banned the manufacture and sale of "unhealthy" cultural shirts in Beijing. The news promoted mottos such as "Study hard and make daily progress" and "I must train myself for the construction of the motherland" (Wu, 2009). In January 2018, China announced the ban of hip-hop culture and tattoos from all media sources (Pasha-Robinson, 2018). Gao Changli, the publicity department director at the State Administration of Press, Publication, Radio, Film and Television of the People's Republic of China promoted regulations such as "Absolutely do not use actors who are tasteless, vulgar and obscene. Absolutely do not use actors whose ideological level is low and have no class. Absolutely do not use actors with stains, scandals and problematic moral integrity" (as cited in PashaRobinson, 2018). 
China aims to promote a positive and healthy image on all media platforms. Since the Cultural Revolution, the Chinese have been developing strong new values and embracing individuality of contemporary culture in an attempt to have a rapport with the outside world. While contemporary advancements are made towards culture, the Chinese government at large still attempts to administer and regulate what's distributed.

\section{Luxury: Object / Experience}

Hyper-consumption is often defined as the extreme maximalist consumption of goods/ commodities for non-functional purposes. Also attached to hyper-consumption is the significant pressure to consume those goods in order to shape one's identity. Can one shape identity without consumption? Luxury, capitalism, advertisement, exclusivity, and authenticity are important social agents to the consumptions of objects and experiences. Advertised goods, travels, and market landscapes form universal codes of luxury that contribute to the representation of "high" status in society.

Every culture has its own definitions of luxury. In China, luxury in the Han Dictionary is defined as something that is the opposite of daily necessity; luxury often refers to consumption that is related to entertainment and decoration. The Chinese MBA Database defines luxury from the economic perspective: as a product that has the highest value or quality based on seven traits. These traits include the material is special and the product is scarce; a symbol of wealth; looks like the nicest; shows the owner's personality; exclusiveness; a sense of distance; and very high emotional value. The Merriam-Webster Dictionary's (2016) definition of the word luxury is "a condition of abundance or great ease and comfort or a sumptuous environment; something adding to pleasure or comfort but not absolutely necessary." The French dictionary Larousse (2018) describes luxury as something slightly different:

Something that is expensive, refined, sumptuous; an environment consisting of expensive objects; expensive and refined way of life or pleasure relatively expensive that is offered without any real need, a great abundance of something (n.p.).

In Latin, there are two similar words with overlapping meanings: luxus, meaning "luxury" or "excess," and luxuria, which meant "rankness" or "offensiveness." By the Elizabethan period, it was associated with adultery, as in Shakespeare's line "she knows the heat of a luxurious bed." Eventually, the word came to refer to a sumptuous environment. Luxure referred to unrestrained sexual pursuits and became a synonym of lasciviousness or wantonness and is associated with words like debauchery and perversity. The etymology course of luxury started with the physical, but then drifted to the material. However, pleasures of the senses were nevertheless always at the root of how we understand the word. Recent research performed by Agility Research \& Strategy, one of the top luxury research firms in Asia, found that Chinese consumers opt for luxury goods over travel. Amrita Banta (2017), Managing Director, notes: 
Different reports and articles have stated that consumers, especially millennials, are spending more on leisure travel, preferring intangible experiences over material goods like handbags, jewelry, or watches as they believe that traveling gives them a more lasting memory and greater happiness. While this may be true in some markets, it is not entirely true in others (n.p.).

The results from the company's 2017/18 "Affluent Insights Luxury Study," which interviewed 3,000 affluent individuals across Asia, found the Chinese story is a little different from other nations in the area. Affluent Chinese consumers are, in fact, spending vast sums of money on personal luxury goods. Their total spending on personal luxury goods (fashion, jewelry, and watches) is $34 \%$, a significantly high margin. In descending order, they found that Chinese spend most of their money on the luxuries of jewelry (12\%), travel $(11 \%)$, clothing $(9 \%)$, watches $(8 \%)$, and entertainment $(6 \%)$, with a very low percentage representing alcohol, gym memberships, and spa visits (Banta, 2017).

In Asia, the concept of "luxury" is still mostly embedded in objects or goods. Banta's (2017) research found that "throughout early historic periods, the Chinese have shown their conspicuous display of wealth and power through material objects. Most notably through the use of gold, ornate jade, and gilded objects" (n.p.). Today, luxury goods are conspicuously displayed at social gatherings, business meetings, and even a date. To the Chinese, luxury still revolves around identity and status symbols.

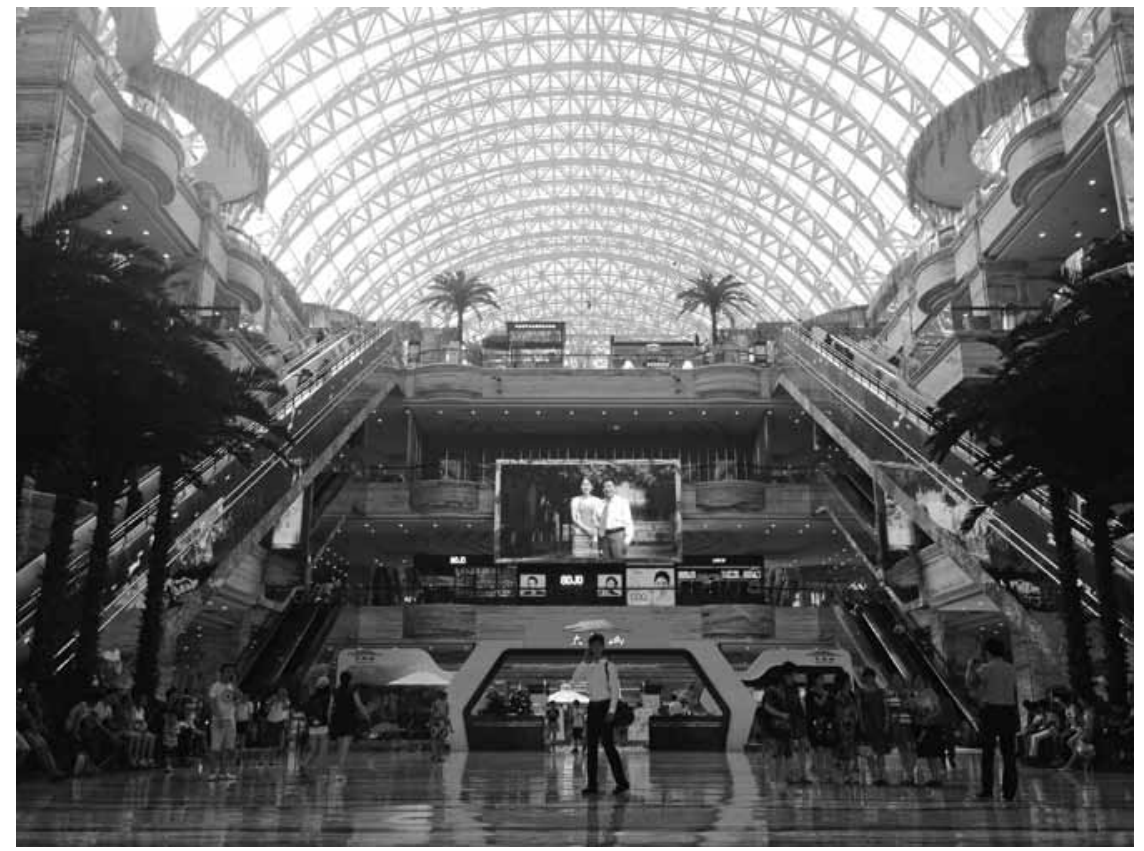

Figure 2. New Century Global Center, Luxury Mall Interior. Chengdu 2016. Photo credits: Joseph Jagos. 
Luxury is often associated with the quest for exclusivity and authenticity. When it is exclusive, luxury becomes a symbol for success. Scheppe (2015) explains that "luxury consumption is the consumption of the feeling of having excluded others [...] and of being able to warm oneself in the agreeable sensation of their admiring envy. It is nothing other than the enjoyment of total separation" (p. 75). Can luxury goods, when serially- and mass-produced, provide a sense of uniqueness to the consumer? Simmel (1957) proposed that "a product has the less soul, the more people participate in its manufacture." Designers are too often considered modern-day gods \& celebrities. The myth of creation by a single person is rooted in the history of religion. Art or craft can be created and produced by a one single person with low technological processes. However, most objects of massconsumption are made through a production flow system that engages dozens, hundreds, or thousands of individuals. Is design less valued when it is mass-produced?

Wang (2013) described authenticity as a salient imperative of identity making that involves strategic, complex processes of semiotic maneuvering that orients towards multiscalar, polycentric systems of norm. In the creators' quests to offer authentic design and identity, they can be viewed as lacking credibility the more aware they become of their outward intentions towards a larger audience. Using brand status to display authenticity often negates credibility. Baudrillard (1968) understood that "the [f] antasy of authenticity is sublime, and it is always located somewhere short of reality (sub limina)" (p. 84). Nothing is ever authentic; the idea of authenticity is an elevated emotion of the purity.

When advertising authenticity, a brand cloaks itself with an "authentic" sense of values marketed to a public's collective identity -and fuels the need for individuality. Guy Debord (1967) describes advertisement as a mise-en-scene in which all are participants are in a perpetual campaign of self-endorsement. Despite the "search for individual," one is constantly in flux and looking for approbation, for collective enviness in the fashion context. Consumers need validation, a sense of collective emotions and personal feeling of higher spirituality or "exclusivity."

In The System of Objects, Baudrillard (1968) also compared advertisement to "a show, a game [...] where an idea (object or experience) is being sold to the world" (p. 187). Advertisement constitutes a useless and unnecessary universe. As stated by Baudrillard (1968), "It contributes nothing to production or to the direct practical application of things, yet it plays an integral part in the system of objects" (p. 178). Advertisement is necessary to create fashion meanings because clothing as material has no meaning. Similarly, Sheppe (2015) believed that "the material constitution of the products is irrelevant" (p. 92) and "the production of a product has become the production of the communication of the product" (p. 90). Thus, in the current global marketplace, the fashion image (or, more broadly, the communication of goods) has become more important than the physical applications of design on the object itself.

\section{Malls: Dream of Consumption}

Hyper-consumption structures, such as malls, demonstrate the power of the manufacturing industries in China. Despite the large amount of abandoned commercial retail spaces, 
China continues to invest in bigger, grander environments for consumption. Some of the largest buildings in the world are located in China. Chinese investors spend tremendous sums of money on erecting giant retail complexes for shopping and entertainment. For example, The New Century Global Center, developed by billionaire Deng Hong's Entertainment and Travel Group based in Chengdu, was created to be less about material consumption and more about experiences. The Center is a place to meet friends, go to video arcades, see a movie, eat, swim, skate, and sing karaoke. The giant space also offers offices, conference rooms, a university complex, two commercial centers, hotels, an IMAX cinema, a Mediterranean-styled "Village", a pirate ship, a church, and a skating rink. The Center's premier feature is a water park named "Paradise Island Water Park" that contains a 5,000 $\mathrm{m}^{2}$ (54,000 square feet) artificial beach where a giant 150 by $40 \mathrm{~m}(490$ by $130 \mathrm{ft})$ screen forms an artificial horizon to replicate sunrises and sunsets. At night, a stage extends out over the pool for concerts. The New Century Global Center is ranked as the number-one building with the largest floor area in the world, containing 1,760, $000 \mathrm{~m}^{2}(18,900,000$ square feet) of floor space, followed by Dubai International Airport's Terminal Three.

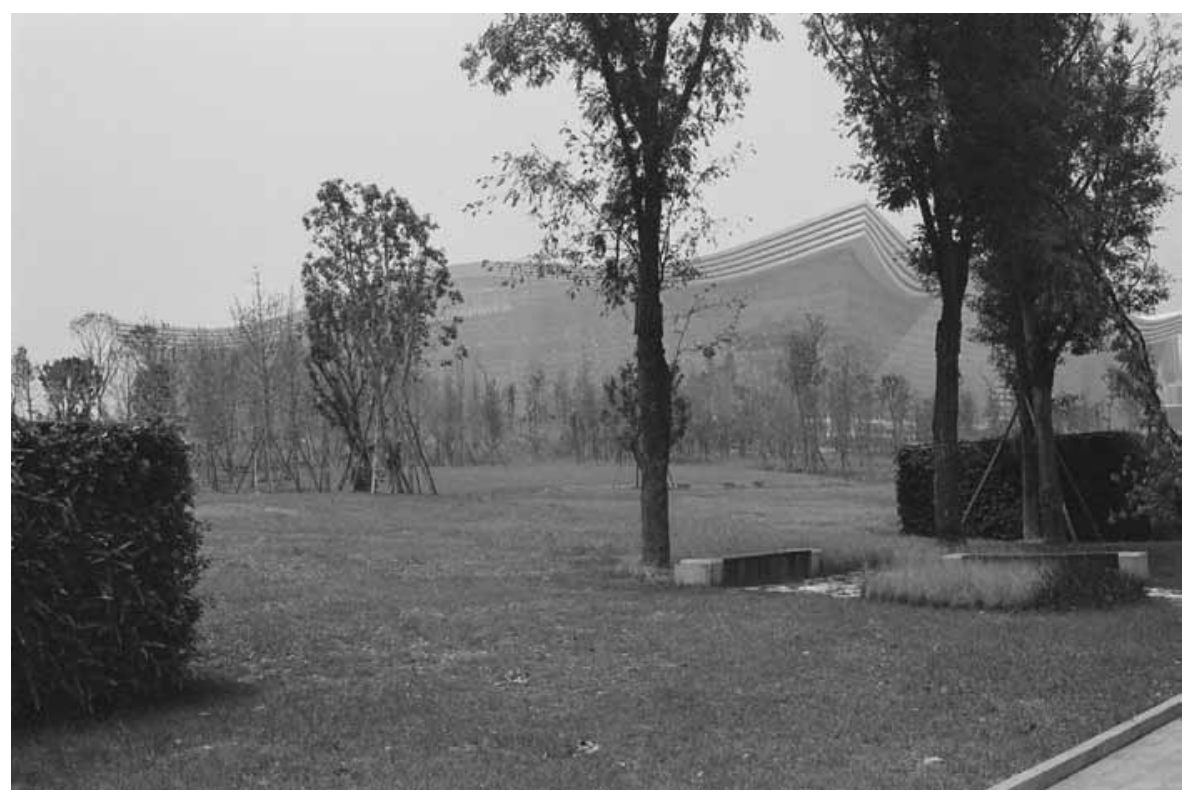

Figure 3. New Century Global Center, Exterior Landscape, Chengdu, August 2016. Photo credits: Joseph Jagos

The slogan of The New Century Global Center is "The One of Everything" (Beam, 2013), thus underscoring its maximalist approach to a maximalist structure. Christopher Beam (2013) wrote for New Republic magazine that "the slogan also nods to the pop-Buddhist 
concept that everything in the universe is one, but with a commercial twist" (n.p.). It seems shoppers can find virtually any object from different market categories and price levels. While China has developed highly unique physical shopping experiences, the nation's business owners have simultaneously created several forms of condensed digital and mobile commerce that are available no matter the shopper's location. For example, consumers can access mobile commerce via WeChat (a social media, communication, and payment platform) even at the smallest farmer booth in the countryside. In contrast to the East, payment options are being created in the West, but consumers are still apprehensive to participate.

\section{Fake}

Today, hundreds of giant hyper-malls all over China are connected to the distribution of fake "stuff." These commercial emblems have become an integral part of China's visual and social landscape. The quantities of fake goods using Western brand images (e.g. logos, symbols, and language) has grown for centuries to become an abstract superstructure of falsely branded lifestyles and design integrity. For example, in a Beijing mall where all garments are sold for less than $\$ 50$ USD each, the decor consists of crystal chandeliers, shiny marble, and mirrors; these overt indications of luxury are important to social status -and shoppers. The aesthetic of the store's environment is of high interest in the context of this research because it lends a form of prestige and exclusivity to the fake goods.

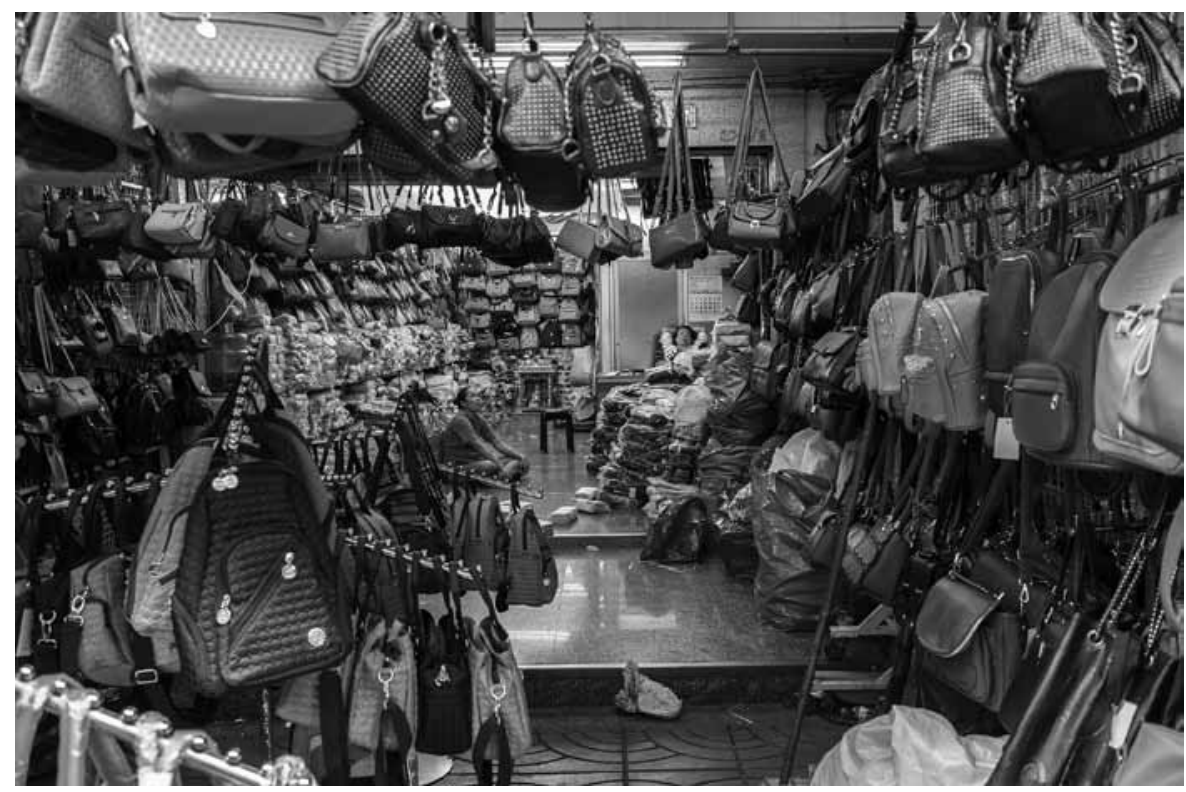

Figure 4. Boredom. Guangzhou, China July 2017. Photo Credits: Marie Genevieve Cyr. 
China's history of replicas has naturally been labeled "imitation" and "knock-offs." The frequently busy and chaotic distribution in China creates a perfect commercial environment for fake goods. With Western designers outsourcing the production of their luxury goods in China, they are losing control over their own supply chains. Legal enforcement of intellectual property rights is growing in the country, but it is still very unrefined and unregulated. Moreover, copying becomes easier due to the designs themselves. For example, ready-towear for mass-production and consumption focuses on basic silhouettes that use various textiles and colors. The simplification of garments' shapes, details, and fabrications make it easy for the development of knock-offs by merely applying a logo. The brand names or logos are subtly disfigured or roughly abstracted at the forefront of production in an attempt to prevent any infringement of copyright. By keeping the process basic and repetitive for factory workers, China has been able to rapidly reproduce the Western massproduction aesthetic.

With the sophistication of the production system, one can recreate an almost exact visual replica of a luxury product. Crewe (2017) tells us,

The emergence of high quality 'super fakes' whose inauthentic assembly is discernible only to the well-trained eye, is damaging the values that are fundamental to the perception of luxury designer brands. The copy, they argue, represents an inferior craft, a failure of creativity.

Fake brands are, after all, "inauthentic only in the eyes of certain people and only in certain moments or contexts" (Craciun, 2014, p. 70). Only through knowledge of the craft can one identify inauthentic products from luxury goods. However, if the products in question are not related to luxury, the low-quality goods still exist as a product of use but not of quality.

Many questions arise due to these factors. Is luxury truly relevant given this ease of abstracting comparable manufacturing methods and materials? Most consumers who buy fake luxury goods don't even know the brand's name, its history, and/or its provenance. How is the value of luxury created, displaced, transformed, and consumed through space and time? How can one convince a consumer audience that real luxury investment can prolong the lifespan of an object through quality and culturally stand the visual test of an aesthetic timeline?

\section{Branding Cultural Experiences}

In China, businesses are not only producing and selling fake goods but also "fake experience." Many abstracted commercial endeavors have surfaced in the past twenty years, from Shenzhen' "Splendid China Park" that offers tourists the experience of a traditional Chinese folk village, to Shenzhen's "Window to the World," where visitors can have their photo taken with all the top iconic monuments in the world including the Eiffel Tower and The Louvre Museum. The New South China Mall in Guangdong, formerly the largest in China, is divided into replicas of popular European cities such as Venice and Amster- 
dam. More or less interested in history, concept, material, and social context of the monuments, the consumers "consume" the image and experience.

When related to experience, where is the line that defines counterfeit or illegal copy? China has developed malls, parks, and architecture that duplicates foreign cultures, environments, and monuments. Is this copying and/or counterfeit? These questions are also relevant in the fashion design context. For instance, the acclaimed fashion house Vetements sews together deconstructed garments made by other fashion brands into a single garment. These garments are then presented as Vetements' own designs. For many, this creative process blurs the line between humor and counterfeit. It also raises significant questions around authenticity, originality, and legality. Is a deconstructed Gucci skirt that is resewn to an Adidas skirt considered a fake? Why is Vetements' appropriation of other fashion brands seen as "cool" and not counterfeit? Is reconstruction -or recontextualization- considered original design? Is it only about logo? Where is the line?

The same can be said about luxury advertisement imagery. On Instagram, many accounts are creating and posting their own advert images from European fashion houses without consent from the designer and/or brand. This is taken further by the owner of the Instagram account “@hey_reilly” who combines current or vintage images that represent the banality of life with the luxury brand logos of Balenciaga, Acne, Celine, Fendi, and more. The account owner's work, in effect, creates a form of advertisement for the brands. Given the popularity of this particular Instagram account, important questions arise: Is it worthwhile for the fashion houses to fight the use of their logs? Or, should the brands use it to their advantage by embracing it as a form of promotion and advertising?

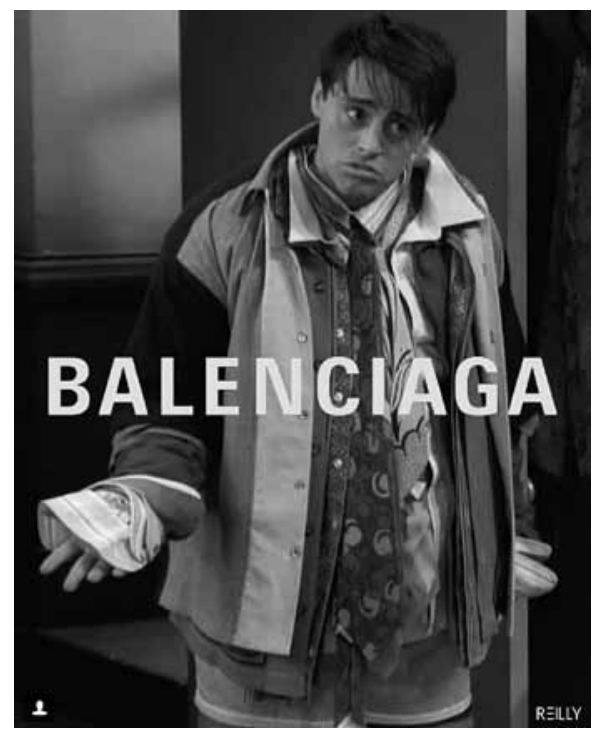

Figure 5.Balenciaga by @hey_reilly

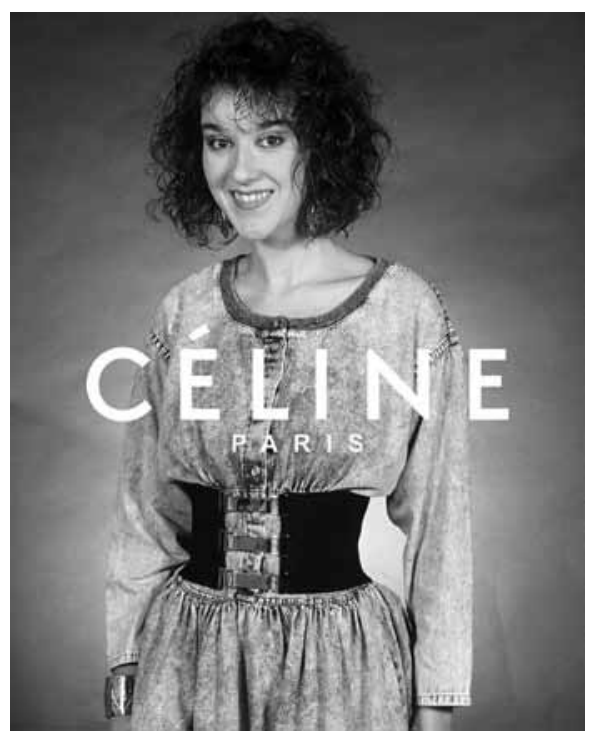

Figure6.Celine by @hey_reilly 


\section{Spirituality}

The ritual of consumption and its social agenda are in constant flux. Douglas and Isherwood (1979) believed that a ritual process' main function consists of gaining meaning from an ongoing change of events. The constant social movements act as a vehicle for capitalism -extracting popular concepts into brand messaging. In one of his most important writings, Guy Debord (1967) found:

Capitalist production has unified space, which is no longer bounded by external societies. This unification is at the same time an extensive and intensive process of banalization. The accumulation of commodities produced in mass for the abstract space of the market, which had to break down all regional and legal barriers and all the corporative restrictions of the Middle Ages that preserved the quality of craft production, also had to destroy the autonomy and quality of places. This power of homogenization is the heavy artillery which brought down all Chinese walls (p. 165).

In his book Supermarket of the Dead: Burnt Offerings in China and the Cult of Globalized Consumption (2016), Friederike Assandri looks at the history of traditional burnt paper offerings in relation to brand status and spirituality; by all appearance, symbolic consumption overlays physical conception. The first records of burnt offerings were made in the form of fake paper money. In modern times, money is still seen as a means to achieving happiness. Scheppe (2016) outlined that "the world of the dead in Chinese popular belief not only continues the earthly materialism of money-regulated economy identified with the concept of happiness: it invests in it with the heavenly sanctification of eternity" (p. 13). The current conception and materialization of wealth is transferred through generations by burning "chic" and fashionable goods replicated in paper to honor one's ancestors. In this spiritual context, authenticity of the artefact is not important. Rather, the representation of things is more valuable. Scheppe (2016) asserts:

Since freed from the obstacle of the unaffordable prices of real equivalent, this symbolic contrivance of objects which people desire and wish to possess expresses, in a spiritual game, the most intimate nature of yearning for commodities, the presence of this demand in material form is a highly informative diagnostic index. A cataloguing of the range of goods destined for the world of the spirits is tantamount to a cartography of the subjectivity portraying itself in its consumer wants. It is a cultural manifestation of something that would otherwise remain concealed (p. 67).

Luxury artefacts are symbols of status beyond physical life. As noted by Scheppe (2016):

The act of burning the paper replicas of money and goods transfers the objects, in the very moment in which they crumble to ashes and go up in smoke, into a world beyond the terrestrial world, where they are placed at the disposal of the 
chaotic pandemonium of ancestors, spirits, and gods that need to be appeased, serving to feed them and meet their needs so that they may be favorably disposed or their hardships assuaged (p. 57).

Scheppe (2016) reminded the reader that "Confucius recommended the sacrifice of representations of things rather than the things themselves as an acknowledgement of the essential difference in the needs of the incorporeal beings" (p. 57). The fact that they are "devoid of usefulness is why it is fitted to the religious practice and the transfer to another world" (Scheppe, 2016, p. 57). Thus, the logo became emblem of holiness.

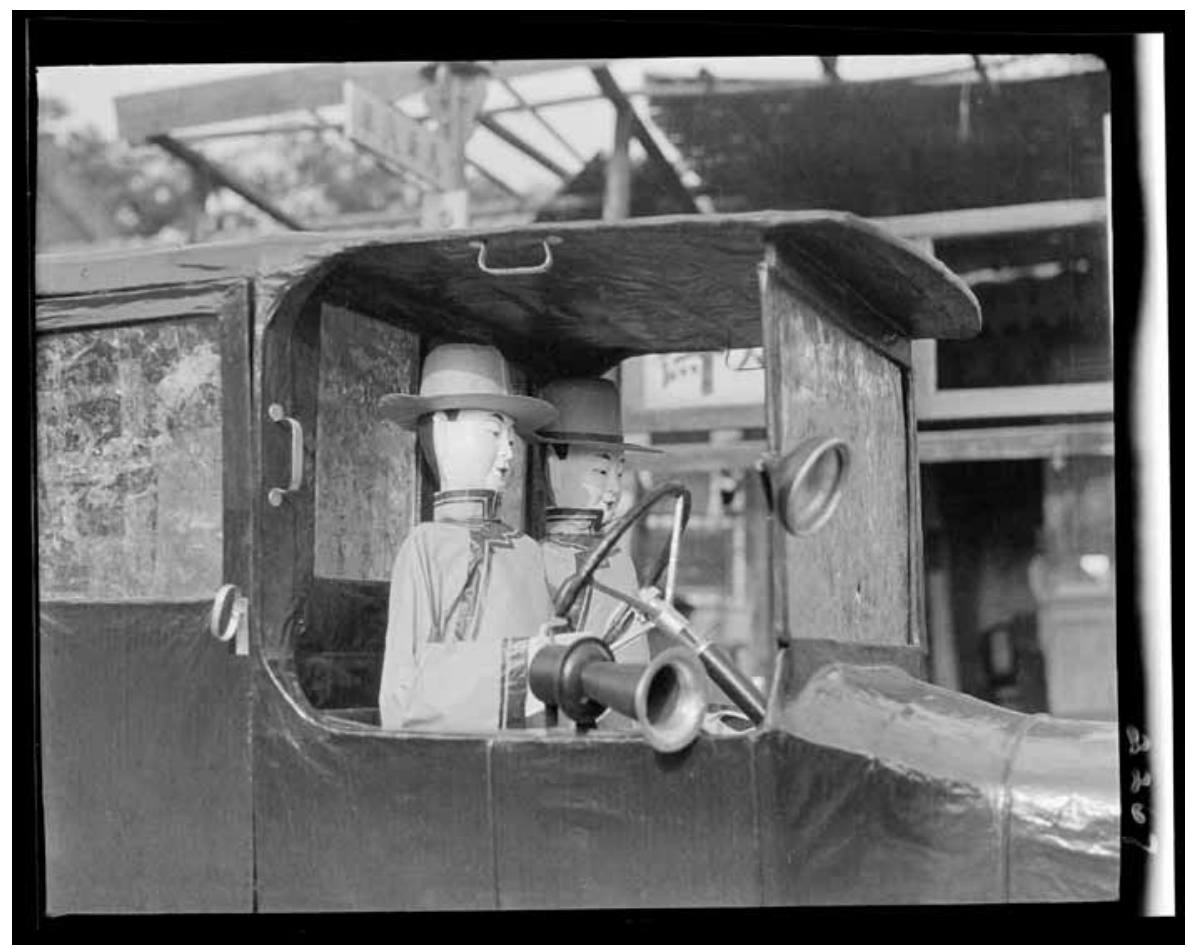

Figure 7. Funeral car, chauffeurs. Photo credits: Sidney Gamble, 1924-27.

In China, one can find life-size 3D paper replicas of luxury goods such as Gucci bags, Prada shoes, Chanel eyewear, Apple computers, and credit cards to be used as burnt offerings. The type of luxury object being represented -and their scale- has had few limits throughout history. In the 1920s, the American photographer Sidney Gamble documented Chinese funerals featuring life-sized models of American cars with two chauffeurs. The paper 
replicas represented the highest monetary investment beside a home, thus symbolizing the power and wealth of its religious devotees making the offering.

Is selling paper copies of luxury goods considered infringement? Luxury brands have hired teams of experts and government officials to fight the production and selling of counterfeit goods around the world. But what about paper non-functional copies? In April 2016, Hong Kong shop owners were surprised to be accused of selling counterfeit Gucci goods. In the article, "Dead Serious: Gucci Warns Afterlife Paper Offering Shops Over Copyright" published by the Hong Kong Free Press, a store owner stated, "I am neither the manufacturer nor the supplier, why are they picking on me?" (Lin, 2016, n.p.). The store owner added that she did not recognize that her paper products resembled Gucci's as she has never owned anything from the luxury brand. Other store owners stated, "We are burning it, not selling it. These products are offerings for the dead, not the living, how are we violating copyright?" (n.p.). These practices raise many questions regarding the symbol of Western luxury and its impact on Eastern spiritual rituals.

\section{Conclusion}

Luxury has become mainstreamed and normalized -or so it appears. It is no longer considered impressive and exclusive to own a Prada bag or Gucci sunglasses. Marketing and branding have built social and human connections to material objects -in this case, clothing. Personal identity has become more complex with various means of communications. In our contemporary society, many people possess multiple identities that they construct, collage, and display in various forms. Clothing is arguably the most valued identity shaper as it is strongly connected to human emotions. The rise of hyper-consumerism gave China the ultimate opportunity to create a new identity for itself through consumption. Following the accumulation of Western social symbols, China is redefining its design aesthetic through heritage and innovation. This clash of visual references has created new markets, discovered new talents, created an obsession with "coolness," and developed large-scale fan databases via social media.

In the constantly evolving fashion industry, one can only question and re-assess the meaning of fashion and its role in society. Given the hyper-accelerated growth of the global market, how can fashion be created for eternity? Or even for a 10-year period? According to famed architect Rem Koolhaas (2013), "There is no future anymore. Everything happens now and if it doesn't you're too late." Nothing is made to last for eternity anymore. Many consumers that live in first-world societies are accustomed to the idea that clothes last a short time before they are to be discarded, thus prompting a culture of "pret-a-jeter" (made to throw away). If we only value visual representation as a society -as opposed to materiality- can designers create garment-image only? The notion of a fashion "collection" loses value as it is of less importance.

This research has shown that people are attracted to the brand experience perhaps more than the object itself. Thus, designers must strive to create new experiences for their consumers since the aura of an experience cannot be counterfeited. Consumers can pay to have a Gucci experience without consuming Gucci garments. The runway show can be 
replicated but the brand experiences that include a discussion, concert, exhibition, or performance cannot be authentically replicated. Will a virtual reality Gucci experience travel to the afterlife? A consumer's environment will become his/her sought after identity.

Author's Note: Hyper-consumerism is being investigated through a series of photographs and creative prototypes -in collaboration with Lamar Billboard Company's Recycling Program - contributing to the creation of new aesthetics and new materials for fashion. Through discussion, writing, and travel with artist and photographer Joseph Jagos, this current research project also investigates hyper-consumerism via the fabrication of industrial items/objects and a series of photo essays. The production of these artefacts involves the materials from industrial advertising processes -such as billboards and banners that feature digitally manipulated imagery. The relationship between advertisement, landscape, and material consumption is depicted in a series of photographs where consumption agents engaging in an over-charged retail or ritualistic space with garments, stuffed, piled, wrapped, and discarded.

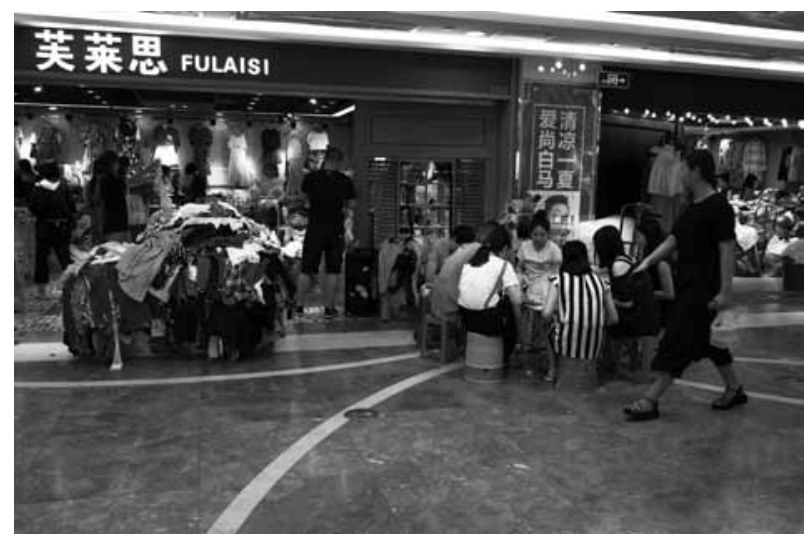

Figure 8 .

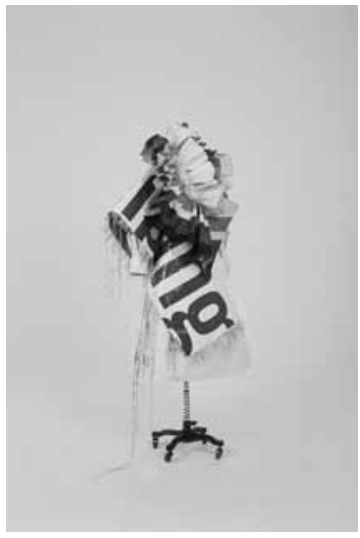

Figure 9.

Figure 8. Counterfeit Mall. Guangzhou, China, July 2017. Photo credits: Marie Genevieve Cyr. Figure 9. Prototype in collaboration with Lamar by Marie Genevieve Cyr, photo by Joseph Jagos.

\section{References}

AFP. (2016, May 6). Gucci apologises over Hong Kong funeral fakes row. Hong Kong Free Press. Retrieved from https://www.hongkongfp.com/2016/05/06/gucci-apologises-hongkong-funeral-fakes-row/ 
Amed, I. (2014, May 5). Building Vogue China. The Business of Fashion. Retrieved from https://www.businessoffashion.com/articles/global-currents/building-vogue-china

Assandri, F. (2015). Supermarket of the dead: Burnt offerings in China \& the cult of globalized consumption. W. Scheppe (Ed.). Cologne: Walther König.

Bain, M. (2017, June 4). The meteoric rise of Chinese consumerism will reshape the world, and maybe even destroy it. QUARTZ. Retrieved from https://qz.com/994345/the-meteoric -rise-of-chinese-consumerism-will-reshape-the-world-and-maybe-even-destroy-it/

Banta, A. (2017, November 10). Why Chinese consumers opt for luxury goods over travel experiences. Luxury Society. Retrieved from https://www.luxurysociety.com/en/articles /2017/11/do-consumers-prefer-luxury-goods-or-travel-experiences/

Baudrillard, J. (1968). The system of objects. Paris, France: Editions Gallimard.

Beam, C. (November 6). One man, 1.7 million square meters. New Republic. Retrieved from https://newrepublic.com/article/115463/worlds-largest-building-area-chinas-newcentury-global-center

Craciun, M. (2013). Material culture and authenticity: Fake branded fashion in Europe. London, UK: Bloomsbury Academic.

Crewe, L. (2017). The geographies of fashion: Consumption, space, and value. London, UK: Bloomsbury Press.

Cheung, A. (2017, February 12). How to reach the elusive Chinese millennial? [interview with Amed, I.] The Business of Fashion. Retrieved from https:/www.youtube.com/ watch?v=lOuRlamvjpo and https://www.businessoffashion.com/articles/voices-video/ angelica-cheung-how-to-reach-the-elusive-chinese-millennial-consumer

Debord, G. (1967/1994). Society of the spectacle. (D. Nocholson-Smith, Trans.). London: Zone Books.

Douglas, M. \& Isherwood, B. (1979). The world of goods: Towards an anthropology of consumption. London: Allen Lane.

Foucault, M. (1988). Technologies of the self: A seminar with Michel Foucault (1st ed.). L. H. Martin \& H. Gutman (Eds.). Boston, MA: University of Massachusetts Press.

Fernandes, C. (2014, December 7). The history of knockoffs in China. Conquer China. Retrieved from http://www.conquer-china.com/land-knockoffs-can-china-innovate/

Gruendl, H. \& EOOS. (2007). The death of fashion: The passage rite of fashion in the show window. New York, NY: Springer Vienna Architecture.

Jolas, M. (1958/1994). The poetics of space: The classic look at how we experience intimate places. (G. Bachelard, Trans.). Boston, MA: Beacon Press.

Julier, G. (2017). Economies of design. London, UK: Sage.

Koolhass R. \& Hoster, H. (2013). Junkspace with running room. London, UK: Notting Hill Editions.

Larousse. (2018). Paris, France: Larousse Incorporated. Retrieved from www.larousse.fr

Lin, G. (2016, April 28). Dead serious: Gucci warns afterlife paper offering shops over copyright. Hong Kong Free Press. Retrieved from https://www.hongkongfp.com/2016/04/28/ dead-serious-gucci-warns-afterlife-offering-shops-over-copyright/

The Merriam-Webster Dictionary New Edition. (2016). Springfield, MA: Merriam-Webster Incorporated. 
Pasha-Robinson, L. (2018, January 23). China bans hip-hop culture and tattoos from all media sources. Independent. Retrieved from http://www.independent.co.uk/news/world/ asia/china-hip-hop-ban-tattoos-media-tv-newspapers-radio-film-a8174501.html

Rearick, L. (2018, January 24). China bans hip-hop culture, tattoos from television. Teen Vogue. Retrieved from https://www.teenvogue.com/story/china-bans-hip-hop-culturetattoos-tv

Simmel, G. (1957). Fashion. The American Journal of Sociology, 62(6), 541-558.

Simpson, C. (2017, September 28). Luxury back in Vogue as China's middle class women lead the way. The Business of Fashion. Retrieved from https://www.businessoffashion.com/ar ticles/news-analysis/luxury-back-in-vogue-as-chinas-middle-class-women-lead-the-way

Tsui, C. (2016, September 1). Top fashion schools in China: Pushing forward despite philosophical divide. The Business of Fashion. Retrieved from https://www.businessoffashion. com/articles/education/top-fashion-schools-in-china-2

Van Bogaert, P., Zoeteman, M., \& Coppens, C. (Eds.). (2017). Eternal erasure - on fashion matters. Berlin: Sternberg Press.

Wang, X. (2015). Inauthentic authenticity: Semiotic design and globalization in the margins of China. Semiotica, 203, 227-248.

Wu, J. (2009). Chinese fashion: From Mao to now. Oxford, UK: Berg Publishers.

Zhen, L. (2017, September 21). Fame academy, the Chinese college offering classes in how to become an internet celebrity. South China Morning Post. Retrieved from http://www. scmp.com/news/china/society/article/2112252/fame-academy-chinese-college-offeringclasses-how-become-internet

Resumen: Es el siglo 21 el siglo chino? La occidentalización ha cambiado casi todas las facetas de la vida en China, a excepción de la política (Wu, 2009). Esto ha creado confusión masiva, entusiasmo, rebelión, romanticismo e idealismo. Las industrias manufactureras de la década de 1990 continuaron dominando la aceleración del consumismo en el siglo XXI y crearon, más que nunca, un mundo de identidad extrañamente gigante y abstracto que se auto creó y se mantuvo. Este artículo examina la política del deseo abstracto, el hiper consumismo y la noción de fantasía en la industria de la moda china. Hoy, cientos de "hipermercados" gigantes que se encuentran en toda China están dedicados a la distribución de "cosas" falsas. Estos emblemas comerciales se han convertido en una parte integral del paisaje visual y social de China. El mercado de productos falsificados que utilizan imágenes de marcas occidentales (ej., logotipos) ha crecido durante siglos hasta convertirse en una gran estructura abstracta de estilos de vida con marcas falsas y diseño integral. El aumento global del hiperconsumo le dio a China la última oportunidad de crear una nueva identidad para sí misma mientras se importa el sueño del lujo: The Buying Power. Este documento se centra en abstraer la noción de hiperconsumismo e interrogar la relación entre la publicidad visual, su materialidad y su representación en el mercado global. ¿Cómo contribuye la publicidad a la producción de bienes de consumo? ¿Podemos crear una visión cíclica de nuevos materiales? ¿Cómo se crea, se desplaza, se transforma y se consume el valor del lujo a través del espacio y el tiempo? 
Palabras clave: Lujo - Identidad - Exclusividad - Autenticidad - Falsificación - Espiritualidad - Consumo - Hiperactividad - Centros comerciales.

Resumo: O século 21 é o século chinês? A ocidentalização mudou quase todas as facetas da vida na China, com exceção da política (Wu, 2009). Isso criou uma enorme confusão, entusiasmo, rebelião, romantismo e idealismo. As indústrias manufatureiras da década de 1990 continuaram a dominar a aceleração do consumismo no século 21 e criaram, mais do que nunca, um mundo de identidade estranhamente gigante e abstrata que foi criado e mantido por si mesmo. Este artigo examina a política do desejo abstrato, o hiper consumismo e a noção de fantasia na indústria da moda chinesa. Hoje, centenas de "hipermercados" gigantes localizados em toda a China se dedicam à distribuição de "coisas" falsas. Estes emblemas comerciais tornaram-se parte integrante da paisagem visual e social da China. O mercado de produtos falsificados que usam imagens de marcas ocidentais (por exemplo, logotipos) cresceu ao longo dos séculos para se tornar uma grande estrutura abstrata de estilos de vida com marcas falsas e design integral. O aumento global do hiperconsumo deu à China a última chance de criar uma nova identidade para si, enquanto importava o sonho do luxo: The Buying Power. Este documento concentra-se em abstrair a noção de hiperconsumismo e questionar a relação entre publicidade visual, sua materialidade e sua representação no mercado global. Como a publicidade contribui para a produção de bens de consumo? Podemos criar uma visão cíclica de novos materiais? Como o valor do luxo é criado, movido, transformado e consumido através do espaço e do tempo?

Palavras chave: Luxo - Identidade - Exclusividade - Autenticidade - Falsificação - Espiritualidade - Consumo - Hiperatividade - Shopping centers.

[Las traducciones de los abstracts fueron supervisadas por el autor de cada artículo] 
Fecha de recepción: abril 2019

Fecha de aceptación: octubre 2019

Versión final: marzo 2020

\section{Changing the Rules of the Game: Sustainable Product Service Systems and Manufacturing in the Fashion Industry}

Noël Palomo-Lovinski ${ }^{\star}$ and Steven Faerm ${ }^{\star *}$

\begin{abstract}
The fashion industry is based on a bygone era in which time is linear and place is specific. This lack of relevancy results in global apparel production that is increasingly inefficient and destructive. The harmful practices of fashion manufacturing industry are no longer permissible in an age that has the knowledge capacity and technological innovations to avoid environmental damage and human inequalities. The deleterious manufacturing practices performed in developing countries contribute to the industry being under continued scrutiny, yet intensifying expectations for fast-paced delivery are at the root of these harmful practices. There is a tacit acknowledgement among fashion industry pundits that historical examples of manufacturing and commerce in the United States do not meet the demands of a society accustomed to instant access, constant change, and low prices. These slower and more traditional models of manufacturing and commerce will increasingly impede profitability in the contemporary marketplace as environmental and social issues continue.

Thus, the fashion industry is in a state flux. Simultaneously, it must decrease destructive practices within the life cycle of clothing while remaining financially sustainable. This binary relationship elicits key questions that can help direct the industry toward a better future. What are the possibilities of domestic apparel manufacturing that utilizes innovative production methods, communication technology, and service systems that, in turn, encourage holistic, sustainable practices? What are the possibilities for and needs of designers who want to take full advantage of an evolving relationship between consumers and designers? In this study, particular attention is paid to new systems of production and distribution that will change the role of fashion designers for the future.
\end{abstract}

Key words: sustainability - fashion design - product service systems - manufacturing technology.

[Abstracts in spanish and portuguese on pages 225-226]

${ }^{(*)}$ Noël Palomo-Lovinski is an Associate Professor at Kent State University in Ohio. She received her B.F.A. in Fashion Design from Parsons School of Design, M.A. in Visual Culture from New York University, and M.F.A. in Textiles from Kent State University. Noël's research focus concerns design responsibility and sustainable practice, future needs of fashion design education, and the relationship between culture and design. 
${ }^{(*)}$ Steven Faerm is an Associate Professor of Fashion Design at Parsons School of Design (Program Director, BFA Fashion Design, 2007-2011). A Parsons alumnus (94') and Designer of the Year Nominee, he began teaching in 1998 while working for designers such as Marc Jacobs, Donna Karan, and Kenneth Richard. He has been recognized for his teaching by winning "The University Distinguished Teaching Award" and The School's "Teaching Excellence Award."

Steven has created college- and pre-college programs and courses for Parsons and other leading international institutions, and has served on academic review boards for Rhode Island School of Design, Pratt Institute, Virginia Commonwealth Institute (VCU), Otis College of Art and Design, and Marist College. He has taught and lectured for institutions including Harvard University, Massachusetts Institute of Technology (MIT), Brown University, Donghua University in Shanghai, The University of Palermo (UP) in Buenos Aires, and The Spero Villioti School in South Africa. Since 2012, he has co-produced an academic journal dedicated to design education between Parsons and UP.

His publications include two books that are featured on international college-level required reading lists and available in seven languages: Fashion Design Course: Principles Practices, and Techniques and Creating a Successful Fashion Collection: Everything You Need to Develop a Great Line and Portfolio. He is currently writing a third book about design education and pedagogy while publishing ongoing research studies in academic journals and serving as a consultant for five publishing houses.

Areas of scholarship and research included the future of art and design education, pedagogy, and student development.

\section{Introduction}

Another example of our intellectual difficulty in thinking simultaneously about continuity and discontinuity, local and global, place and non-place, emerges in art and artistic creation in general. If the relation between artistic creation and our history is difficult to pin down these days, it is precisely because time is accelerating and, as if it were, evading us, and because the overlaying of temporal language by special language, the primacy of code, which prescribes behavior, over the symbolic, which constructs relations, shapes the conditions of artistic creation.

—Marc Augé, 2008, XVII

Our conceptions of time and place have been irrevocably changed by technology, yet the international fashion industry's practices remain steadfast and unadjusted to these new models. In today's global marketplace, many first-world consumers can buy any product they want, when they want it, how they want it, from virtually any source and location in the world, all for a relatively low retail cost. The antiquated and slower-paced methods and processes of domestic manufacturing that were prevalent in the nineteenth and twentieth centuries have been replaced with a crisscrossing global network of highly accelerated 
manufacturing that demands more and more materials that, in turn, rapidly deplete the earth of its resources. These environmental demands simultaneously strain an immense workforce that makes, distributes, and transports vast quantities of manufactured goods all over the globe -often under limited worker's rights, unethical business practices, and dangerous factory conditions (Fletcher, 2008).

The result is a hyper-accelerated manufacturing and distribution system that creates and seeks to satiate the consumer's unquenchable and rapacious desire for novelty. Yet, the consumer's sense of novelty is fleeting and vague, thus encouraging a nefarious cycle of increased acceleration that further escalates environmental damage and broadens the divide between the "haves" and the "have-nots." A concerted effort has been made by those concerned with this growing environmental and ethical dilemma to find solutions that promote a sustainable fashion industry and a flourishing economy -but not at the expense of the larger ecosystem or society itself.

Possible solutions may come in the form of Product Service Systems (PSS) that take advantage of locality and promotes opportunities for an extended relationship between the consumer, the product, and -in select systems models- the designer. PSS may gain appeal and subsequent implementation due to several factors that include mounting interest in domestic apparel manufacturing (Lee, Levy, Fen, \& Yap, 2015), production machinery innovations that encourage small batch production, and the ubiquitous nature of communication technology that enables garment production from seemingly anywhere in the world. This proposed network of an apparel design, production, manufacturing, retail, and disposal system would create an alternative to the fashion industry's current practices that undermine efforts in sustainability, while leveraging the geography and human capital of the U.S.

This paper discusses global and local manufacturing as it relates to the current and evolving fashion industry. A literature review of current PSS models is provided and followed by the authors' proposal for Sustainable PSS (SPSS) that enhances the PSS model. This paper offers a speculative SPSS construct as a reproducible closed-loop scenario that takes advantage of time and place as contextualized within a global society dominated by technology.

\section{Global and Local Manufacturing}

Throughout the twentieth century, most of what Americans wore was made in the U.S. (Novellino, 2015). Legislation - such as the North American Free Trade Agreement (NAFTA) - erased import duties, and by the 1990s, less than 3 percent of the clothing worn in the United States was American-made (Clifford, 2013; Novellino, 2015). To remain competitive, U.S. retailers relocated their manufacturing overseas where labor was less expensive and environmental protection and human rights laws were lax. Retailers were then able to offer cheaper clothing, resulting in higher sales volumes and accelerated manufacturing that met inflated demand (Kunz \& Garner, 2011).

After the shift to overseas manufacturing, access to extensive fashion imagery on Internet search engines worldwide has permanently sped up the rate of visual consumption. This imagery, accessible around the world, creates a heightened awareness and subsequent 
demand for fashion from viewers. This has led to unprecedented rates of consumption that retailers respond to with great zeal. Fast-fashion retailers, including Zara, Hennes \& Mauritz (H\&M), and Forever 21, use "just-in-time" or "postponement manufacturing" practices (Christopher, 2000), as well as "on-the-floor" and social-media sales intelligence that mitigates the impact of the shifting balance of price-versus-style demands (Chaudhry \& Hodge, 2012; Christopher, 2000). Additionally, these retailers stimulate consumption by using short runs to engender a sense of scarcity and "grab it while you can" consumer psychology. For example, Zara delivers a new shipment of merchandise every two weeks, thus increasing sell rates, decreasing overstocks, and forcing sale prices (Christopher, 2000). Many industry researchers and analysts predict the acceleration of the fashion cycle will only increase, and that customers will expect increased customization (Amed, Berg, Brantberg, Hedrich, Leon, \& Young, 2016). Simultaneously, as these fast-fashion retailers and manufacturers compete to be faster in style turnover, they must also lower prices to stay competitive. Consumers now pay less for more clothing (Kunz \& Garner, 2011). This fact alone suggests a finite time period before costs outweigh financial returns (Joy, Sherry, Venkatesh, Wang, \& Chan, 2012; Jung \& Jin, 2014) and, indeed, in 2016 the fashion industry suffered another year of slight sales growth, slowing to a mere 2 to 3 percent (Amed et al., 2016).

Unmitigated consumption, driven by style websites, blogs, and the very nature of fastfashion apparel itself, increasingly calls into question what we have traditionally seen as trends. Trends have always marked time in fashion (e.g. flappers in the 1920s and the miniskirt in the 1960s), yet as the Internet catalogues an infinite simulacrum of fashion images, time is rendered irrelevant. Similarly, place -or time as it relates to place- is no longer meaningful since international fashion brands are required to concurrently create items for diverse international marketplaces. Design houses routinely feature a range of fabrics to service all seasons in all parts of the globe, within one collection or seasonal delivery. All fashion companies -from those in the high luxury markets to the most inexpensive fast-fashion retailers- have unmitigated expectations of constant, fast-paced aesthetic changes. This "break-neck" pace of the global fashion industry promotes subjective obsolescence and decreases the probability of true innovation beyond its most basic form. Several initiatives and trends fomenting within the cultural zeitgeist point to new opportunities for change (Soper, 2008; Shah, 2013). Traditional paradigms -such as those of the automobile industry- have shifted, allowing specific innovations or workload allocation to diffuse to local sites rather than a single manufacturing center (Florida, 2002). Food retail shops or restaurants selling produce from international, national, and local sources satisfy local tastes, and offset overhead costs and supply needs while lessening their carbon footprint. Local products inspiring deep loyalty and pride within the U.S. can be seen in the ascendance of craft beer within the American market. Nielsen, the global measurement and data analytics company, states the "dollar sales growth in the craft realm ranged between just over 15\% to just over 18\% from 2013 through early 2016, well above the $1.3 \%-3.5 \%$ posted by the overall beer category (excluding flavored malt beverages, ciders and seltzers)" (Nielsen, n.p.).

The slogan "Buy Local" initially may have referred to locally produced food or handmade products, but is now used for clothing and fashion products as well. Web directories and 
services, such as Maker's Row, connect local manufacturing or production services with entrepreneurial designers. Several incubation and accelerator programs promote new approaches to retail, start-ups, and artisanal product manufacturing. Many easily accessed documentaries and books also highlight the environmental and social concerns associated with the fashion industry. Consumers, therefore, are increasingly being asked to consider the ethics of purchasing, and the implications of unmitigated consumerism of fast-fashion apparel made in environmentally and/or socially harmful conditions (Soper, 2008; Fletcher, 2008).

\section{Need for Change}

The global fashion industry is ever changing, due to increasing environmental and social issues. These issues are, in turn, coupled with decreasing profitability. This combination creates opportunities for a reimagined set of best practices. Advances in communication, information, and manufacturing technologies have facilitated a change in the geography of production (Labrianidis, Kalantaridis, \& Dunford 2011) from the U.S. outward. Centralized manufacturing and trade from one, singular urban center -as was the case of New York City's Garment District- is no longer useful due to its relative unprofitability.

Global fashion capitals, such as New York, Milan, or Paris, are no longer the monoliths of design. Traditionally, creative resources -such as visual imagery- have been found almost exclusively in physical locations, such as museums, galleries, and shops. Now, online resources such as Google, Pinterest, and YouTube are free and accessible to anyone, located virtually anywhere on Earth. These Internet-based fashion hubs offer audiences tremendous opportunities to find inspiration. They enable creative individuals around the world to inspire others and instigate new trends. There are now viable opportunities to offer a wider spectrum of choice, both to those working in the fashion industry and to the consumers who buy from it.

The need for greater efficiency and agility is a compelling argument (Hagerty \& Magnier, 2015) for the development of more efficient systems of design, production, distribution, and disposal. A company's economic longevity is intricately tied to its ability to facilitate consistent change in products and processes, and generate new opportunities based on constant communications with their customers (Florida 2002). These demands of efficiency dictate a revaluation of traditional practices in the fashion industry that increasingly strain the environment.

One example of the inefficient practices that concurrently result in environmental damage is that of cotton production in Texas. The U.S. state is the leading cotton-producing state in the nation and the global market, having produced 16 million bales of cotton in 2014 (Novellino, 2015). Despite this rich, local resource, the U.S. ships most of its cotton overseas to be made into textiles, apparel, and other products. The goods are shipped back to the U.S. for Americans to purchase. Once these products are discarded, most of goods that are not discarded as trash are shipped to developing countries as second-hand clothing (Fletcher, 2008). Throughout the current set of supply chain practices, efficiency and agility are increasingly harder to achieve, due in part to the mammoth scale of the industry 
and its hyper-accelerated speed that prioritizes output and delivery over best sustainable practices and waste reduction. This realization has inspired many to consider alternative ways of doing business.

\section{Product Service Systems}

Product Service Systems (PSS) are an extension of service and potential contact beyond a product's point of sale. PSS as a business concept has been around since the 1990s. Since then, PSS has had increasing applications within the fashion industry (Cheschin, 2013; Vezzoli, Chechin, Diehl \& Kohtala, 2015). PSS is closely connected to increased attention to the user experience and creative narrative of a brand in support of differentiation within the competitive product market (Jacob \& Ulaga, 2008). It has been pointed out that PSS does not guarantee sustainable practice and, in fact, has the potential to exacerbate the very issues around sustainability (Rexfelt \& Hiort af Ornäs, 2009; Ceschin, 2013).

The Sustainable Product Service Systems (SPSS) that have thus far been proposed have focused on renting, redesign or alterations, co-design, and wardrobe consultation as well as "take back" disposal (Armstrong et al., 2014; Gelbmann \& Hammerl, 2015). However, initial consumer perceptions and receptivity investigations into SPSS suggest that many consumers are hesitant to adopt SPSS due to perceived decreases in usability, or an increase of costs, and a sense of unfamiliarity with how any of these services might work within the supply chain (Armstrong, Niinimäki, Kujala, Karell, \& Lang, 2014; Vezzoli et al., 2015). As SPSS becomes a greater part of the market, and with a significant increase in its available advantages, this hesitation is expected to lessen. There is also strong evidence that there are many internal barriers within existing companies to SPSS, since it means financial investment in major reorganizations of production, distribution, and disposal systems, as well as requiring a shift in mindset among market participants (Martinez, Bastl, Kingston, \& Evans, 2009; Vezzoli et al., 2015). The authors believe the proposed SPSS offers a distinct advantage to the next generation of designers, retailers, and the fashion industry.

\section{Sustainable Product Service System Proposal}

A primary objective of SPSS would be to reduce the extent of carbon footprint produced through the manufacturing and distribution of products. To achieve this, an SPSS would require several geographically dispersed hubs, or outposts, most likely in larger cities for ideal operation. These hubs would feature design departments, production rooms, manufacturing, retail, and "take-back centers" that would enable a closed-loop system within the market. Through SPSS, market participants would have a greater sense of connection between consumer, designer, and manufacturer (Vezzoli et al., 2015). Further, an SPSS that is specific to the community or region would encourage trust due to the greater sense of transparency, access, and collaboration it provides consumers. The local SPSS will also be an essential part of sustainable consumption behavior since tangible environmental damage or social malfeasance is harder to ignore, as was recently shown through a study 
conducted in New Zealand (Lee, Levy, Fen \& Yap, 2015). It is essential however that the cost associated with any SPSS would not be prohibitive and would rely on alternative or different modes of production.

Mudambi (2008) notes that vertical integration of manufacturing processes within one locality is a crucial attribute for market participants to gain future competitive advantages. Currently, local small businesses, which usually have a slower rate of fashion production, cannot take advantage of the larger resource savings resulting from the economies of scale inherent in SPSS (Jung \& Jin, 2014). This concept can be illustrated with the example of a proposed SPSS structure that spans several U.S. states, supports the macro-acquisition of goods related to scale, and additionally enables interaction on a micro-level with consumers and communities. In such an SPSS structure, greige (undyed) fabric, equipment, machines, and other overhead costs would be consolidated to achieve greater savings and efficiencies due to economies of scale. Each hub would interact as links in the web of a national brand, yet serve as local, individualized places.

The SPSS focus on dispersing apparel production would also benefit external and supporting businesses within each included community. Evidence suggests that the advancement and economic sustainability of any community is predicated on new businesses or high-tech industry fostering industrial linkages with both business markets and government, and alternative business structures within a larger infrastructure (Glasmeier, 1988). As an example of these types of linkages, McRobbie (2013) cites government initiatives in Berlin which provide training and education around product creation to underrepresented and migrant populations. As a result, these workers became productive members of society while also supporting burgeoning fashion enterprises which contribute to Berlin's overall economy. A strong, viable community and economy demands environmentally and socially sustainable best practices that must be fundamentally inherent in any new fashion business (Fiksel, 2003). The essential factor in a future sustainable fashion system is that those very same populations that have traditionally worked in low-wage or dangerous conditions would be able to take on greater responsibilities, with a wider set of creative contributions, and with increased wages.

\section{Design}

Designer expectations and requirements are quickly changing to reflect the fluctuating apparel market. The role of the fashion designer as an "all-knowing style dictator" no longer works in an age predicated on constant change, simultaneous trends, and increasingly discerning consumers (Craik, 2009; Partington, 2014). Retailers rely on surveys and data-mining sources to accurately gauge what is important to consumers (Meyer, 2001). This data should be fully utilized to implement initiatives which would attract and incentivize consumers while simultaneously supporting specific sustainability issues that fashion companies believe are strategically important for future success. Meyer (2001) suggests that sustainable fashion is not evaluated solely on its environmental impact by most consumers, but rather on durability, look, and price. It is essential, then, that the industry create sustainable environmental and social actions in conjunction with economic sustainability to achieve success in this new world. 
To best incorporate the needs and constraints of designing within a sustainable paradigm, designers must specialize in one of two streams of production. For example, a proposed SPSS could feature a group of designers that would create small-batch collections based on the needs and wants of existing customers through the local retail outlet. These designers would also help propagate creative style directives inspired by aesthetic or cultural research. These designers would target the wide range of age, socio-economic, and cultural requirements, as well as the physical environment of the specific locality in which they work. The retail and take-back centers would provide useful and immediate information to design and production. Cross-pollination between departments or activity fields may be improved due to linked specializations, such as design with marketing or sales and after-sales services (Mudambi, 2008).

In conjunction with this first group of designers, a second group's primary objective would be responsible for designing clothing returned to the take-back center. This clothing would only be from the company group to ensure sustainable fibers and recyclable color and finishes, as well as quality of fibers and workmanship. Each returned garment would be evaluated for recyclability, with gently used or newly mended clothing resold. Clothing with a major flaw prohibiting resale would be disassembled or re-utilized for an upcycled garment. For those garments beyond repair or already upcycled, the fiber would be shredded or composted. Additionally, this second group of designers would interact with the communities offering upcycling services, in which consumers could actively participate. A consumer could make an appointment with a designer, allowing extended use of garments due to alterations instigated by the customer.

\section{Production}

The fast fashion retailer Zara has become the gold standard of fashion businesses; 85 percent of Zara merchandise is sold at full price, while the industry standard is generally 60 to 70 percent $(\mathrm{Lu}, 2014)$. Upwards of 60 percent of Zara clothing is made near company headquarters in Spain, utilizing highly automated factories (Christopher, 2000). Zara has become the foremost example of how technology can positively affect the future of the fashion industry. Digitization of the supply chain increases efficiency, lowers procurement costs, and allows for greater connection and customization (Amed et al., 2016). Commonly used materials are tracked, and fabrics are held in greige so that looks can quickly change based on fluctuating consumer interest (Christopher, 2000). Generic shapes are held in postponement until specific style details are known, allowing for increased mass customization and a nod to momentary trends.

Improved cost efficiency and responsiveness to consumer needs opens a revaluation of production. Amed et al. (2016) suggest that an increase in mechanization and technological advancements is the only way to successfully create a sustainable (environmentally, economically, and socially) manufacturing system. Within the localized scenario proposed here, small-batch, mechanized manufacturing would accommodate controlled cycle acceleration and any specific customer needs, while emphasizing a local and sustainable practice. Product would be carefully evaluated and considered to ensure products are made for specific consumer needs. 


\section{Educational Needs in Support of SPSS}

As the fashion industry is being forced to meet the new construct of declining natural resources, increasing environmental pollution and climate change, as well as an increased interest in accountability by customers, so too must higher education in fashion programs consider how best to meet the challenges of the twenty-first century (Wolf \& Rhee, 2009). Traditional design programs rooted in Bauhaus ideologies must give way to advanced curricula that promotes a greater understanding of the interconnectivity design plays in the world. Lydia Matthews, Professor of Visual Culture at Parsons School of Design, describes this new direction by stating:

[Designers] recognize that they need to have an understanding of world systems, whether they're economic, social, ethnographic, or cultural. At the same time, social scientists (...) are beginning to understand that the systems they work with are in fact designed and that there's a fundamental need to communicate visually and materially across cultures and in a globalized condition (Agid, 2008, p. 13).

To support this need -particularly in context of SPSSs- new initiatives in design education must increasingly prioritize curricula that prepare students for their new role - from one who is a "style dictator" to one that works collaboratively in cross-disciplinary teams. Disciplinary overlaps and adjacencies will allow students to better understand how their practice and skillsets situate themselves within a broader context. Simultaneously, the approach will also allow the designer to interface with new methodologies that may then be synthesized with their own specific approaches. A more porous relationship with other fields must occur in order for students to look beyond the traditional "silo" of fashion design. As Zimmerman (2003) notes:

While design research comes in many forms, ranging from quantitative market research to personal interviews, experimental design analysis and qualitative research, it also represents a willingness to look beyond the immediate concern of crafting a project, as well as an openness to integrating new insights into the design process itself (p. 25).

Thus, the design and business students who have traditionally worked in different spaces -the literal and the figural- must coalesce if the fashion industry is to develop and implement successful SPSSs. The design students will come to understand marketing, consumer relations, and business systems. The business students will gain insights into fashion-specific design processes, sustainability in the garment-making context, and required resources. This shared understanding of the other's discipline, and attendant problems that need solutions, will generate more thoughtful proposals for increasingly successful outcomes.

The authors believe a key principle in this educational model that supports SPSSs will be curricula that teaches students the vital, participatory role consumers can play. In our 
over-abundant and hyper-accelerated world, consumer behaviors have changed exponentially. The over-abundance of the marketplace requires designers to discover the emotional needs of their audience, rather than solely the material needs that have been met, and even over-met (Pink, 2005). Given the increasingly active role the consumer plays -and the decreased role the designer plays as "design dictator"- it is essential for students to be taught how to actively listen and absorb information from their audience while also providing leadership around design problems.

Design education must therefore instill a new series of attributes in students that move well beyond technical acumen and aesthetics. These traits include a consistent openness to design thinking and strategy, and the ability to rely on fundamentally shifting constraints, opportunities, and solutions due to developments in technology and sustainable practices (Wolf \& Rhee, 2009). Students and professionals will have to "comprehend both the problem and the context of the problem and how to design or create solutions that are efficiently and aesthetically desirable for the community" (Van Zandt, 2011, n.p.). There will be a new generation of graduates who possess broader interdisciplinary knowledge with which they can "understand the socio-cultural, political and commercial implications that design can have in the society, and not only the immediate aesthetic, functional and/or structural applications of design" (Muratovski, 2010, p. 385).

\section{Conclusion}

The prescient vision of the fashion industry is shaped by the duality of clear social and environmental harm with the capacity of innovation, change, and motivation to design a better world. This paper considers ways that could engage communities to consider clothing production much like food consumption. The slow food movement encourages local organic farming, thoughtful consumption, and methods of creating more closed loop systems (such as composting). These farmers and farmers' markets encourage community participation and transparency. So too can the consumable product of clothing become locally based with greater concern for the environment and the people it serves.

The proposed Sustainable Product Service System would create a locally considered space that promotes site-specific design, manufacturing, and retail in conjunction with a global perspective, presence, and digital distribution of ideas. The capability of creating such a system is possible; the technology is present and the business systems currently employed are successful. As such, the authors' proposal is an amalgamation of existing concepts and practices that are brought together for a more efficient and beneficial purpose. Supply chain resources would be consolidated for more efficient distribution using the same postponement policies used by Zara. Digital and technological applications within the supply chain would allow a considered approach to individual sales as well as a continued connection to any specific consumer. This proposal seeks to be a part of the community, generating local economies and tailored products that better target and meet consumers' needs. Transparency, education, and interaction would enable designers, manufacturers, and retailers to not only encourage consumers to be more thoughtful consumers, but to also have a better idea of what consumers truly want. Thus, the authors' proposal is part 
of a widespread desire to ameliorate the destructive practices of the fashion industry while continuing a profitable and thriving industry.

\section{Resources}

Agid. S. (2008, fall). Re: Imagining Parsons--How Parsons' new academic structure is shaping design education in the 21st century. Re:D, 26(2), 10-15.

Amed,I., Berg, A., Brantberg,L., Hedrich, S., Leon, J., \& Young, R. (2016). The state of fashion. The Business of Fashion. Retrieved from https://www.businessoffashion.com/ site/uploads/2016/11/The_State_of_Fashion_2017.pdf

Armstrong, C., Niinimaki, K., Kujala, S., Karell, E., \& Lang, C. (2014). Sustainable product service systems for clothing: Exploring consumer perceptions of consumption alternatives. Journal of Cleaner Production, 97, 30-39.

Augé, M. (2008), Non-places: An introduction to supermodernity, New York: Verso.

Ceschin, F. (2013). Critical factors for implementing and diffusing sustainable product service systems: Insights from innovation studies and company's experiences. Journal of Cleaner Production, 45, 74-88.

Chaudhry, H. \& Hodge, G. (2012). Postponement and supply chain structure: Cases from the textile and apparel industry. Journal of Fashion Marketing and Management, 16(1), 64-80.

Clifford, S. (2013, September 19). U.S. textile plants return with floors largely empty of people. The New York Times. Retrieved from www.nytimes.com/2013/09/20/business/ us-textile-factories-return.html?

Christopher, M. (2000). The agile supply chain: Competing in volatile markets. Industrial Marketing and Management, 29, 37-44.

Craik, J. (2009). Fashion: The key concepts, New York: Berg.

Fiksel, J. (2003). Designing resilient, sustainable systems. Environmental Science \& Technology, 37(23), 5330-5339.

Fletcher, K. (2008). Sustainable fashion and textiles: Design journeys. London: Earthscan.

Florida, R. (2002). The learning region. In Gertler, M.S. \& Wolfe, D. (Eds.), Innovation and social learning: Institutional adaption in an era of technological change. New York: Palgrave MacMillan.

Gelbmann, U. \& Hammerl, B. (2015). Integrative re-use systems as innovative business models for devising sustainable product-service-systems. Journal for Cleaner Production, 97, 50-60.

Glasmeier, A. (1988). Factors governing the development of high tech industry agglomerations: A tale of three cities. Regional Studies, 22.4, 287-301.

Jacob, F. \& Ulaga, W. (2008). The transition from product to service in business markets: An agenda for academic inquiry. Industrial Marketing Management, 37, 247-253.

Hagerty, J. \& Magnier, M. (2015, January 13). Companies tiptoe back towards 'made in the USA. The Wall Street Journal. Retrieved from www.wsj.com/articles/companies

Joy, A. Sherry, J., Venkatesh, A., \& Chan, R. (2012). Fast fashion, sustainability, and the ethical appeal of luxury brands. Fashion Theory, 16(3), 273-296. 
Jung, S. \& Jin, B. (2014). A theoretical investigation of slow fashion: Sustainable future of the apparel industry. International Journal of Consumer Studies, 38, 510-519.

Kunz G. \& Garner, M. (2011). Going global: The textile and apparel industry (2 ${ }^{\text {nd }}$ Ed.). New York: Fairchild.

Labrianidis, L., Kalantaridis, C., \& Dunford, M. (2011). Delocalization of economic activity: Agents, places, and industries. Regional Studies, 45.2, 147-151.

Lee, C.K.C., Levy, D.S., \& Yap, C. S. F. (2015). How does the theory of consumption values contribute to place, identity, and sustainable production? International Journal of Consumer Studies, 39, 597-607.

Lu,C. (2014). Zara supply chain analysis: The secret behind Zara's retail success. Retrieved from www.tradegecko.com/blog

Martinez, V., Bastl, M., Kingston, J., \& Evans, S. (2009). Challenges in transforming manufacturing organizations into product service providers. Journal of Manufacturing Technology Management, (21)4, 449-469.

McRobbie, A. (2013). Fashion matters Berlin; City-spaces, women's working lives, new social enterprise? Cultural Studies, 27(6), 982-1010.

Meyer, A. (2001). What's in it for the customers? Successfully marketing green clothes. Business Strategy and the Environment, 10, 317-330.

Mudambi, R. (2008). Location, control, and innovation in knowledge intensive industries. Journal of Economic Geography, 8, 699-725.

Muratovski, M. (2010). Design and design research: The conflict between the principles in design education and practices in industry. Design Principles and Practices: An International Journal, 4(2), 377-386.

The Neilsen Company. (2017, May 15). The state of the U.S. beer market. Retrieved from http:// www.nielsen.com/us/en/insights/reports/2017/the-state-of-the-us-beer-market.html

Novellino, T. (2015, July 2). Made in the USA clothing: Rare but worth it. New York Business Journal. Retrieved from www.bizjournals.com/newyork/.../made-in-the-usa-clothingrare-but-worth-it.html

Partington, A. (2014). Class, clothes, and co-creativity. Clothing Cultures, 1(1),7-21.

Pink, D.H. (2005). A Whole new mind: Why right-brainers will rule the future. New York: Riverhead Books.

Rexfelt, O. \& Hiort af Ornäs, V. (2009). Consumer acceptance of product service systems: Designing for relative advantages and uncertainty reductions. Journal of Manufacturing Technology Management, (20)5, 674-699.

Shah, D. (2013). Happy-nomics. In Brand, J. \& Vos, M. (Eds.), A fashion odyssey: Progress in fashion and sustainability. Arnhem, The Netherlands: ArtEZ Press.

Soper, K. (2008). Alternative hedonism, cultural theory and the role of the aesthetic revisioning. Cultural Studies, 22(5), 567-587.

Van Zandt, D. (2011). Inaugural address. Retrieved from http://www.newschool.edu/leader ship/president/installation/

Vezzoli, C., Ceschin, F., Diehl, J.C. \& Kohtala, C. (2015). New design challenges to widely implement sustainable product service systems. Journal of Cleaner Production, 97, 1-12.

Wolff, L. \& Rhee, J. (2009, May). Is design the new liberal arts? Re:D (Regarding Design),(26)6, 9-13. 
Zimmerman, E. (2003). Creating a culture of design research: methods and perspective. B. Laurel (Ed.). Cambridge: MIT Press

Resumen: La industria de la moda se basa en una época pasada en la que el tiempo era lineal y el lugar específico. Esta falta de relevancia da como resultado una producción global de vestimenta que es cada vez más ineficiente y destructiva. Las prácticas nocivas de la industria de fabricación de moda no son permisibles en una época que tiene la capacidad de conocimiento y las innovaciones tecnológicas para evitar el daño ambiental y las desigualdades humanas. Las prácticas de fabricación perjudiciales realizadas en los países en desarrollo contribuyen a que la industria siga bajo un escrutinio continuo, pero la intensificación de las expectativas de una entrega rápida está en la raíz de estas prácticas dañinas. Existe un reconocimiento tácito entre los expertos de la industria de la moda, donde los ejemplos históricos de fabricación y comercio en los Estados Unidos no satisfacen las demandas de una sociedad acostumbrada al acceso instantáneo, el cambio constante y los precios bajos. Estos modelos más lentos y tradicionales de fabricación y comercio complicarán cada vez más la rentabilidad en el mercado contemporáneo y ambiental, haciendo que los problemas sociales continúen. Por lo tanto, la industria de la moda está en un estado de cambio. Simultáneamente, deben disminuir las prácticas destructivas dentro del ciclo de vida de la vestimenta sin dejar de ser financieramente sostenible. Esta relación binaria provoca preguntas clave que pueden ayudar a dirigir la industria hacia un futuro mejor. ¿Cuáles son las posibilidades de la fabricación de ropa nacional que utiliza métodos de producción innovadores, tecnología de comunicación y sistemas de servicio que, a su vez, fomentan prácticas holísticas y sostenibles? ¿Cuáles son las posibilidades y las necesidades de los diseñadores que desean aprovechar al máximo una relación en crecimiento entre consumidores y diseñadores? En este estudio, se presta especial atención a los nuevos sistemas de producción y distribución que cambiarán el papel de los diseñadores de moda para el futuro.

Palabras clave: Sostenibilidad - diseño de moda - sistemas de servicio de productos - fabricación - tecnología.

Resumo: A indústria da moda é baseada em uma época passada em que o tempo era linear e o local específico. Essa falta de relevância resulta em uma produção global de roupas cada vez mais ineficiente e destrutiva. As práticas danosas da indústria de confecção da moda não são permissíveis em um tempo que tenha a capacidade de conhecimento $\mathrm{e}$ inovações tecnológicas para evitar danos ambientais e desigualdades humanas. Práticas de fabricação prejudiciais nos países em desenvolvimento contribuem para o contínuo escrutínio da indústria, mas a intensificação das expectativas de entrega rápida está na raiz dessas práticas prejudiciais. Há um reconhecimento tácito entre os especialistas da indústria da moda, onde exemplos históricos de manufatura e comércio nos Estados Unidos não atendem às demandas de uma sociedade acostumada ao acesso instantâneo, às constantes mudanças e aos baixos preços. Esses modelos mais lentos e tradicionais de fa- 
bricação e comércio complicarão cada vez mais a lucratividade no mercado contemporâneo e ambiental, fazendo com que os problemas sociais continuem. Portanto, a indústria da moda está em estado de mudança. Simultaneamente, as práticas destrutivas dentro do ciclo de vida das roupas devem diminuir, permanecendo financeiramente sustentáveis. Esse relacionamento binário levanta questões-chave que podem ajudar a liderar a indústria em direção a um futuro melhor. Quais são as possibilidades de fabricação de vestuário nacional que utiliza métodos de produção inovadores, tecnologia de comunicação e sistemas de serviços que, por sua vez, promovem práticas holísticas e sustentáveis? Quais são as possibilidades e necessidades de designers que desejam aproveitar ao máximo um relacionamento crescente entre consumidores e designers? Neste estudo, atenção especial é dada aos novos sistemas de produção e distribuição que mudarão o papel dos designers de moda para o futuro.

Palavras chave: Sustentabilidade - design de moda - sistemas de serviços de produtos fabricação - tecnologia.

[Las traducciones de los abstracts fueron supervisadas por el autor de cada artículo] 
Fecha de recepción: abril 2019

Fecha de aceptación: octubre 2019

Versión final: marzo 2020
Immersion in the Workplace: A Unique Model for Students to Engage in Real-World Service Design

Anezka Sebek * and John Jones **

\begin{abstract}
Since 2015, Fjord and Parsons School of Design have been collaborating to create a mutually beneficial alternative to internships by immersing Design and Technology graduate students in the one-week Fjord Immersive Design Studies. The Design Studies at Fjord operate outside of direct client work and are a perfect vehicle to engage students in structured human-centered design research.

The mission of the Fjord/Parsons Immersion Program is to influence the future of design, to shape future designers, and to propel Fjord's service design innovation. For the Parsons students, the experience as contributing members of a service design team is an unusual benefit. While traditional months-long internship programs can sometimes be a strain on company resources or an unproductive learning experience for students, the Fjord/ Parsons Immersion Program is an excellent alternative training opportunity to engage students in meaningful work to achieve valuable research in human-centered service design for Fjord. This paper discusses six cases of Parsons graduate students who benefitted from the program.
\end{abstract}

Keywords: rethinking internships - design practice - design research - design thinking design study - service design.

[Abstract in spanish and portuguese on pages 244-245]

(*) Anezka Sebek, Ph.D. Associate Professor of Media Design Parsons School of Design. Anezka Sebek designs curricula in the BFA/MFA Design and Technology Programs and teaches in studio and thesis courses. Her current research includes the pedagogical implications of emerging immersive media such as virtual, augmented and mixed reality. Before teaching full-time, her extensive career in the film industry included projects for television, advertising, documentaries, and feature films. She was a visual effects and computer animation producer for technologically complex projects that combined live-action with digital effects. She has written, produced, and directed music videos, narrative shorts, and documentaries. Ms. Sebek served on juries for Association for Computing Machinery Siggraph Electronic and Animation Theater and Ars Electronica (Linz, Austria). The PostCity Ars Electronica Festival Expanded Animation Panel (2015) invited her to speak about education and the changing fields of new media and animation. In February of 2017, she curated the New School Nth Degree Series Immersive Storytelling Symposium. In January of 2018, she traveled with Sven Travis, Director of the MFA DT Program and 28 students, 
to The India Institute of Technology in Gandhinagar, India to participate in Design for a Billion, a two-week study that explored complex design problems and their possible solutions in a rapidly developing nation. Her Ph.D. in Sociology (2016) dissertation, Family Homelessness in the Small City is an ethnographic qualitative methods study of the social strata and bureaucracies that control the lack of affordable housing and living-wage jobs in post-industrial Northeast American cities.

${ }^{(*)}$ John Jones, Senior Vice President and Design Strategy Lead at Fjord, New York. John Jones is SVP Design Strategy at Fjord, collaborating with global Fjord studios on futurefocused methods and services, executive-level creative and strategic leadership, designing new processes and products that span mobile, web, social and physical spaces. He and Roman Kalantari founded the Fjord Makeshop, and the Design Studies Process. The Makeshop is a focused, tactile process, co-creating with clients to physically build services and quickly learn from experimentation to help the service evolve with deeper understanding. Fjord Design Studies is a continuous Design Exploration process. In an effort to sustain innovation, this process identifies human-centered Design Study themes to explore. By focusing on behavior, interaction with devices, environments and human needs we are able to uncover unexpected new service models. The Makeshop "build to think" iterative design process has resulted in hundreds of innovations for clients and many 'firsts' in Times Square, retail spaces, and mobile platforms. Previously, John was SVP, Executive Creative Director at R/GA where he founded R/GA's Global Retail and Digital Environments practice and the R/GA LAB, an exploration and workshop space dedicated to consumer insights and new methods of interaction for in-store, mobile, online and branded environments.

\section{Introduction}

The authors of this article knew each other as faculty in the Master of Fine Arts [MFA] in Design and Technology Program at Parsons School of Design, a college within The New School University. A few years ago, John Jones, Senior Vice President of Design Strategy at Fjord, attended one of Anezka Sebek's studio critiques at Parsons. One student was a very capable thinker and creator; his rough prototypes were imaginative, yet he never fully realized his projects and often abandoned his ideas. Anezka had noticed a similar lack of students' self-confidence in their creative process and their lack of understanding of the progression from ideation and prototyping to fully realized work. At their monthly breakfast, Anezka asked John about internship opportunities at Fjord so that the students in the MFA program could be exposed to a professional studio where ideation, prototyping, and implementation were a daily routine. However, John expressed his frustrations with interns who need too much nurturing for the short time, and the limited attention they have away from school, thus hampering the effective use of their talents. At the same time, he saw an opportunity to include students in Fjord's week-long Design Studies. Instead of a long-term internship, the Fjord/Parsons Immersion Week gives a Parsons student the opportunity to participate in the Design Study as a full-time member of a Fjord creative team. 
Most internships are exploitative or, at best, give students only a tiny glimpse into the world of work that is awaiting them. During the last economic recession in the U.S., internships exploited students more and more, and this added to the lack of integration of new talent in the workplace (Perlin, 2012). The economic crisis and attendant employment downturn are over, yet even in this historical moment of nearly full employment in the U.S., professional studios continue to acquire unpaid interns so the company can gain research and exploration at little to no cost. This use of unpaid interns for the studios' creative teams creates tension and contradiction. The student-interns offer their free time and creativity (receiving minimal personal benefit) while the studio exploits the relationship by using interns' work in the research and exploration for new ideas -and fiscal gain. This contradiction is called "organizational ambidexterity" in the management literature. As Andriopolous and Lewis (2010) note:

Companies frequently attempt to gain a competitive advantage in their market through innovation, yet this critical factor is often elusive. Obtaining innovation requires both exploration to tap new opportunities and exploitation to enhance existing capabilities (p. 104).

John Jones, as Design Strategy Lead, and Roman Kalantari, as Senior Design Director at Fjord, created an opportunity for employees to explore by performing ongoing research and experimentation in a process they call Design Studies. At the end of every week, Fjord runs a Design Clinic where designers come together to present and learn from each other and industry thought-leaders. At the Design Clinic, creatives also present findings from that particular week's Design Studies. Fjord's homegrown design research time thus seemed like a natural opportunity for "exploiting" Parsons' graduate students who could add to Fjord's exploration aims. The students benefit by participating as fully recognized contributors to the creative team while providing their services at no cost. According to Roman, "This has become a way to tap into the skills and enthusiasm of design students to focus on unsolved problems in [service] design. Fjord [in turn] gets quite a bit of value out of this great program." To be clear, the student's time is transformed into a learning opportunity rather than an exploitation of his or her eagerness to enter the industry.

Parsons and Fjord began the pilot study program with the student John and Anezka identified during Anezka's studio critique. The experiment was productive for Fjord as well as for the student (see Student A's Case); The Immersion Program has continued ever since. For each program, Anezka selects students well in advance of the week's start date. In Anezka's role as an Associate Professor of Media Design in the MFA Design and Technology Program at Parsons, she has contact with a community of over 160 graduate students from which she can draw candidates. Always on the lookout for the next Immersion Week candidate, she might see a student's work in a critique, or the student will come to her for career or study advice. She bases her selection of the student on a wide and intuitive set of criteria of need, demonstrated talent, imagination, high degree of persistence, and collaborative spirit. The winter, spring, and summer breaks in the graduate school calendar are the perfect timeframe for giving one student, one week at a time, the opportunity to participate in the Fjord studio's mutual exchange of teaching and learning. 
The six case studies presented here are the first candidates in the Parsons/Fjord program since its inception in 2015. We anonymized students' identities at their request. Parsons and Fjord signed mutual non-disclosure agreements. The chosen Fjord Design Study theme is outside of paid client work, so it does not mandate a tangible product or outcome. Fjord and Parsons can share the resulting work and insights, thus exercising the paradoxical and "ambidextrous exploitation and exploration" model for the benefit of the company as well as for the student.

\section{Fjord and Parsons Background}

Fjord, founded in 2001 by Olof Schybergson, Mark Curtis, and Mike Beeston, aims to be a global leader in service design innovation. In 2013, Accenture PLC acquired Fjord and its design services in strategy, consulting, digital, technology, and operations of approximately 435,000 employees worldwide and $\$ 34.9$ billion USD in revenue. Service design evaluates the entire consumer experience and looks to improve the quality of that experience, or to create a new service. Service design uses methods and tools derived from different disciplines, ranging from ethnography to information, and management science to interaction design. The company often addresses design problems categorized as "wicked" by Rittel and Webber (1973) because they are grounded in cultural and social human conditions. To report on these difficult to solve business problems that seek a wide range of solutions, Fjord maintains a constant online blog presence, as well as a Twitter account and additional forms of social media.

The Fjord/Parsons collaboration is ideal. Parsons School of Design, established over one hundred years ago, is one of the colleges within The New School University. The School maintains a Paris campus, partners with several academic institutions around the world, and offers curricula that prioritizes global thinking, research, and experimentation. This academic approach meshes well with Fjord's global expanse and ongoing research and quest for innovation. The opportunity for Parsons students to engage as professional studio creatives, even for one week, also adheres to the School's goal of producing highly prepared graduates. The pursuit of design process innovation is also part of the college's curriculum. Within Parsons' Design and Technology MFA Program, established in 1997, the curricula address the challenges of designing for new tools in the context of rapidly emerging electronically networked technologies, and their effects on life on the planet. The cases presented here focus on process and findings for both Fjord and Parsons, thereby showcasing the nature of the Fjord/Parsons collaboration.

\section{The Fjord Design Studies Process and Methods}

Similar to the design thinking process codified by Tom and David Kelley at Stanford University's Design School in the early 1990s, a design study at the Fjord office begins by exploring a specific human-centered theme. For the Fjord team, the reason for the term "study" is to avoid the common industry discussions of "failing fast." If explorations are viewed 
as a "study" there is no need to fail at all. Examples of Fjord Design Studies include zero user interface (designing user interactions without screens), designing for relationships, extending community interactions, and data privacy. The week-long exploration focuses on defining hypotheses and experiments. It includes field interviews and observations in the target community, as well as the hands-on prototyping of ideas in the Fjord Makeshop. The week culminates in a presentation of these findings at the Fjord Design Clinic on Fridays. Fjord identifies the human-centered themes for the creative team and the student to explore. In Design Studies, the research is about human behavior as it applies to interaction with devices, environments, and human needs. The company looks to uncover new interactions and expectations for what it calls "Living Services," or "next wave design where experiences evolve and sculpt around unique human needs." The hands-on Design Studies processes create what Fjord aims to be a "habit of invention." The aim is to identify areas of interest, conduct research, prototype, observe, field test, and document the entire process which then becomes the raw materials for designing new "Living Services."

Fjord Design Studies have resulted in compelling points of view such as extending communities, guidelines for wearables, gesture interactions, invisible user interface, voice control, data visualization, and a collection of patent pending innovations. The Design Clinic is the Friday forum for continuous work, where the studio's designers share new techniques. Fjord also invites guest speakers so they, too, may share new techniques and insights with the Fjord staff. Because the company is always evolving, its Design Studies continue as new needs and technologies emerge. Active documentation of the process in the form of a short description of findings lays the groundwork for new services. Not all of the work performed is purely speculative however; Fjord Design Studies, with Parsons students, have advanced to patents and final product prototypes.

\section{Fjord's Makeshop}

The unique studio environment at Fjord includes a dedicated workshop space that facilitates co-creation with clients to develop innovative products and services. The proprietary Makeshop "build to think" process encourages a hands-on creative process, research, and field-testing to deepen the exploration of new ideas and services. Engaging in physical exploration is critical to the design process. The Makeshop allows creatives from all disciplines to collaborate in an open-ended physical exploration that leads to key insights about behavior and services.

\section{MAKESHOP INGREDIENTS}

\begin{tabular}{|c|c|c|}
\hline SPACE \& MATERIALS & PROCESS & DESIGN STUDIES \\
\hline $\begin{array}{l}\text { DEDICATED SPACE } \\
\text { LOW FIDEUTY MATERIALS } \\
\text { ACCESSIBLE TO ALL }\end{array}$ & $\begin{array}{l}\text { BUILD TO THINK } \\
\text { OPEN-ENOED EXPLORATION } \\
\text { OPEN TO ALL DISCIPUNES }\end{array}$ & $\begin{array}{c}\text { FOSTER GOOD HABITS } \\
\text { CREATE NEW TYPES OF PROJECTS \& } \\
\text { WORK } \\
\text { PARTNER WITH DESIGN PROGRAMS } \\
\text { GLOBALIY }\end{array}$ \\
\hline
\end{tabular}


Following the Immersion Week research and observation in the field, all of the Parsons students cited the Makeshop as a place that is essential to fully experimenting with making their ideas into rough three-dimensional prototypes. The Makeshop process is critical for exploration and process since Fjord has found most people associate sketching with finished, beautiful art. The Makeshop introduces easily malleable materials of foam, cardboard, and tape, and this severs the notion of creating something fully finished. The materials alone prevent the prototype from becoming overly "precious" and completed. Rather, the process opens up the playful exploration of ideas in prototypical form. The Makeshop materials are unthreatening but allow for rapid development. The progression from what can be considered "low fidelity" to more evolved materials offers ideators a lowstakes opportunity at exploration.

In the Fjord Makeshop, one of the goals is the rapid progress of service concepts: building things to think through problems with a focus on designing for human needs and behavior. The team attempts to remove blockages for advancement in the project. Fjord Design Studies consider "technology last." Thus, the team makes software or hardware platform suggestions only when there is full, initial understanding of human behaviors and needs.

\section{PROGRESSION OF MATERIALS}

\begin{tabular}{|c|c|c|c|}
\hline LOW FIDEUTY & MEDIUM FIDEUTY & HIGH FIDEUTY & PRODUCT LEVEL \\
\hline PAPER & SKETCHUI ON DEVICES & $\begin{array}{l}\text { DESIGNED UION } \\
\text { DEVICES }\end{array}$ & $\begin{array}{l}\text { FUNCTIONAL UI ON } \\
\text { DEVICES }\end{array}$ \\
\hline CLAY & CUT FOAM MOCKUPS & CUT FOAM MOCKUPS & 300 PARTY \\
\hline $\begin{array}{l}\text { BALSA WOOD } \\
\text { LINOLEUM }\end{array}$ & $\begin{array}{l}\text { MACHINED MDF OR } \\
\text { WAX }\end{array}$ & $\begin{array}{l}\text { MACHINED METAL AND } \\
\text { ACRYLIC }\end{array}$ & $\begin{array}{l}\text { FABRICATION } \\
\text { CUSTOM ELECTRONICS }\end{array}$ \\
\hline pre & $\begin{array}{l}\text { THERMOFOORMED } \\
\text { PLASTICS }\end{array}$ & CUSTOM ELECTRONICS & $\begin{array}{l}\text { FUNCTIONAL } \\
\text { SOFTWARE }\end{array}$ \\
\hline PROXY DEVICES & BASIC ELECTRONICS & BASIC SOFTWARE & \\
\hline
\end{tabular}

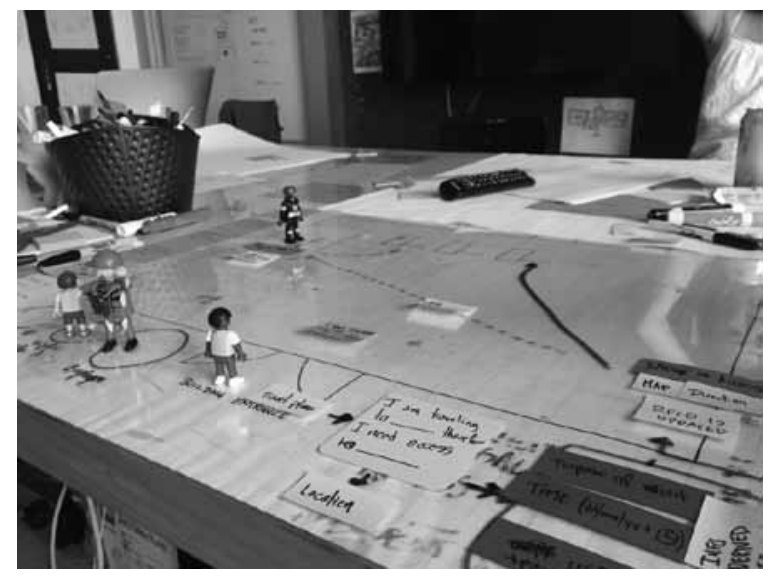




\section{The Use of "Bench Time" for Innovation}

Fjord uses Design Studies to perform further service design research of problems that clients may not ask to be solved, and for which there would otherwise be no resources or designers assigned. To explore new ideas, John and Roman request the participation of Fjord designers who are between projects (or, waiting "on the bench" for assignment to their next job). Design Studies are a great way for a creative team to learn new problemsolving processes. The result of leveraging this "bench" or "idle" time is that many creatives feel like they do more service design in a week of Design Studies; the Design Study experience challenges them to look at human behavior in ways that may be unexpected, and at a much faster pace than typical client-based work. This time-pressured process helps designers become more effective idea generators and problem solvers.

At the beginning of the Fjord/Parsons Immersion Week Program, it was a challenge to get a Fjord creative team assigned. However, in the second year of the program, the company created a training accounting code for the Design Study. Operationally, this allowed creatives to bill their study as training, thus leveraging their time "on the bench." When the opportunity to use a Parsons student arises, the appropriate Fjord creatives are booked in advance. This ensures there is a complete creative team well suited for the Parsons Study theme.

Every quarter, the Design Study outcomes, surprises, and human behavioral insights are collected in one-page Design Study summaries. Creative teams use these findings and outcomes in the problems they encounter in paid work, thus channeling idle, or "bench time," into exploration and future client-based work. Conversations with clients facilitate the use of Design Study insights to create further research problems to explore. John also distributes outcomes to the Fjord and Accenture teams outside of the New York Studio so they can put the team members to work on paying projects.

\section{The Parsons/Fjord Immersion Week}

\section{The First Friday}

The student participates in a Fjord Design Clinic. Fjord is a learning organization, and the Design Clinic every Friday is an opportunity to teach/learn a skill, or to host guest speakers who engage the studio in workshop activities. The student meets the two- or threeperson team they will be working with during the Immersion Week.

\section{Monday - Tuesday}

Research on the theme begins with desk (online, library) research that then extends outside of the studio to research in the field amongst a target population. Often, the team will create questionnaires or other activities for the larger studio or target audience to explore.

\section{Wednesday - Thursday}

Makeshop: The team develops several iterations of physical prototypes to explore ideas revealed in the research activities and discussions. 


\section{Friday}

At the Friday Design Clinic, the Parsons student discusses his/her background and graduate research, and what he/she learned during the Immersion Week at Fjord. Fjord uses these findings for the advancement of the creative process at the studio as it participates in teaching design and finding new talent. Several of the students ended their work in the Design Study with a Friday Design Clinic workshop in order to further explore the results of the week's Design Study Theme.

\section{Student Meeting and Selecting the Theme}

After a meeting with the new student candidate, Fjord selects a theme they are interested in exploring. Often, the student's background (or skillset) guides or inspires the selection of the theme. The Design Study themes are often, but not always, a reflection of what the student might be researching in their graduate school projects. These range from how people feel about the use of drones in public space, to fundamental studies of communication without screens, to designing for empathy, or generalized client challenges Fjordians may encounter from previous projects or studies. What Fjord needs from the week is new insights into human behavior that can then drive service design for a variety of applications with diverse clients.

At the first Friday Clinic, the student expects a design brief. Roman believes that people become stuck in research, and this may inhibit the use of their intuition and the imagination that is necessary for innovation. The student does not receive the theme assignment until Monday, so he/she goes home "empty-handed," a bit confused, but excited after the Friday Clinic.

The Friday Design Clinic is often unrelated to the theme the student will be working on, but it serves as the beginning of a dialogue about the week's theme. The student is asked, "What did you take away from that Design Clinic?" The answer provides some insight for a theme selection. It is important to find out what the student thinks the week is going to be about. The Fjord team then likes to be sure it is not quite what the student expected. As John states, "Whatever they thought it was on day one, over the course of the week, it's not what they thought."

\section{Redirection and "Storming"}

The Immersion Program's teaching style simulates real-world production where the needs and wants of a client may constantly shift. Part of the Design Study process is to disrupt expectations purposefully and to continuously stimulate the creative process. Thus, the aim is for participants to generate as many alternatives, combinations, and new questions as possible, just as designers are encouraged to do during classic brainstorming sessions (Osborne, 1963). John and Roman agree that the final goal of the Design Study is to produce new and surprising insights about human behavior. 
To meet these goals, and thereby please the people at Fjord, the students often assume they need to invent something brilliant and new. However, although sometimes the finding(s) may seem trivial and small to the student, it is the insight surprise that John and Roman are actually seeking. Students need to be able to hypothesize, reflect, make, notice, and report the findings from the study, as Donald Schön teaches us. The practice of experimentation is one of constant recursion and iteration. Schön (1983) notes:

The situation talks back, the practitioner listens; and as [s/he] appreciates what $[\mathrm{s} / \mathrm{he}]$ hears, $[\mathrm{s} / \mathrm{he}]$ reframes the situation once again. [S/he] describes as "continual self-frustration," [s/he] sets a restructured problem of interpretation which guides his [or her] further inquiry. In this reflective conversation, the practitioner's effort to solve the reframed problem yields new discoveries, which call for new reflection-in-action. The process spirals through stages of appreciation, action, and re-appreciation (p. 132).

To facilitate this process of staying loose and messy -yet reflective in the process- "freak out," or panic moments about the object of the design study are created. As soon as the student and the creative team gets comfortable, the team is re-directed. John and Roman have found that the process of constant redirection to encourage new ways of looking at a problem stimulates imaginative and creative thinking. It prevents the team from getting "precious" about the solution they have created, and this allows for the continuous evolution of the processes and ideas. A successful Design Study week produces behavioral findings that further the Fjord company aims of service design innovation.

\section{Six Immersion Candidates and their Projects:}

A. Graphic designer, but someone who is interested in pushing drone technology and a variety of concept and research methods. Project: Human interaction with drones: identifying specific behaviors, concerns and human reactions to awareness of drones and design of drone devices

B. An experienced international commercial director who embarked upon an MFA in DT to understand the U.S. market and also hone his skills as a creative in the four semesters. Project: Designing for Empathy: Focus on understanding and communicating wheelchair user experience to non-wheelchair users

C. Our youngest immersion candidate, yet someone who is a thinker and creator in a varied set of directions from narrative, design process, education, and industry. Project: Personal Privacy: defining our relationship with privacy and identifying ways people might be more likely to give up private information

Continue $>$ 
D. A mature industry systems analyst and experienced manager of software and data projects in collaborative settings. Project: Communicating Personality: finding simple combinations of words and pictures, which can be absorbed in a glance and help us communicate personality - going beyond the bio description and photo

E. Branding professional with little experience in a formal design process. Leadership qualities and the ability to present complex research and prototype ideas. Candidate E was the first, second year student we selected for the program. We originally decided that first year students would be ideal because we expected that the Fjord Immersion Program would prepare them for the design and creative processes during their thesis development. This candidate did not come to Anezka's attention until the second year of their graduate studies. Fjord ultimately hired this candidate as a full-time employee. Project: Identifying behavior in physical spaces: logging behavior of people in specific spaces and identifying the right types of concepts to guide them to experiences

F. An experienced graphic and web designer. Project: How can we create a visual experience that tells this story in a three-panel system and allows the user to engage with the product?

\section{Outcomes of Parsons/Fjord Design Studies}

Being the first student in the Immersion Program was a challenge for Student A. Student A had a background in graphic design and undertook graduate studies in the Design and Technology Program to increase his skills in programming and overall knowledge of emerging media. His interest in experimenting with people's attitudes toward drone technologies became the theme of his week at Fjord. In the service design industry, it is more important to focus on behavior and attitudes than the technological invention itself. For Student A, The Immersion Program was an opportunity to provide himself with "a greater understanding of interaction design and the drone industry, but also an understanding of the ability to answer critical questions through an accelerated and collaborative process."

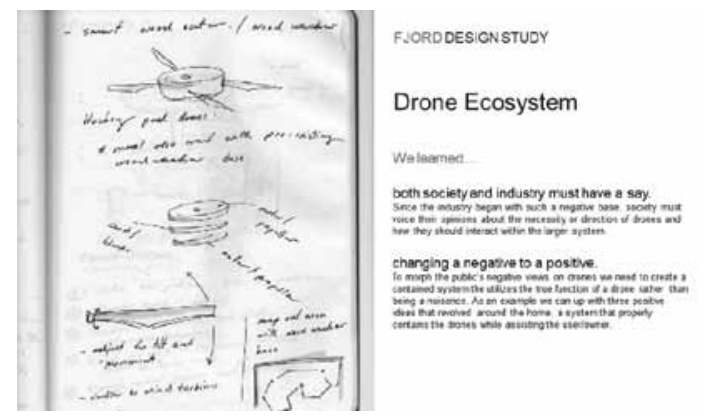


Student A used universal research methods and the Fjord creative team's content mapping process. He first created and tested a survey with a wide range of people to understand views on the military, commercial, and personal drones along with predictions of drone use in the future. However, the constant redirection for Student A was to keep people's attitudes in the center of his study, rather than his fascination and love of the drone technology. Here, he reports on his findings:

First, with the excessive use of drones during wartime efforts, people associate these machines/vehicles with killing. Second, even with drones becoming more popular in the public's eye, there is a still a level of being uncomfortable and annoyed by a drone's presence. This level of annoyance could be caused by noise, privacy or even physical damage. Lastly, $47 \%$ of people still believe drones are negative and predict a higher usage in public spaces in the near future. These results and patterns were used to create actionable insights that validated assumptions and questions. I began questioning what the projected trends of drones would become, and how people could begin to interact with them in a more civilized and positive way. I wanted to engage people in the conversation. I wanted people to walk away with a basic understanding of drones and how they can and will affect our lives in the future. The immersion and final findings presentation was the perfect platform to develop and begin the conversation.

The success of Student A opened the door for more students to participate in the Program. The range of graduate students in the Immersion Program has offered different levels of successful outcomes.

Student B was an industry professional who had embarked on a graduate degree in the Design and Technology Program to broaden his understanding of the global industry, and to experience production and education in the U.S. The assignment for Student B arose out of a project Fjord had already assigned as a Design Study topic. He describes his experience:

When I started, the wheelchair project was a simple [virtual reality] exercise [for the Design Study] but I thought it was very promising. I used my one week to help the project reach its potential. Above all, it required an insight to go beyond a trivial experience and become a service idea and experience with human impact. Our research showed that unpleasant first day challenges in wheelchairs would be a good problem to tackle with the tools at hand. This quickly led us to the idea of a Wheelchair Training Program - a simulator offering a safe way to engage with a complex new environment and serving as a way to understand the new obstacles and issues. Along with the concept, I proposed some prototypes for the [user interface] and the simulation. We tried to make sure it didn't feel like a game; we did not want to create a superficial or insensitive experience. 


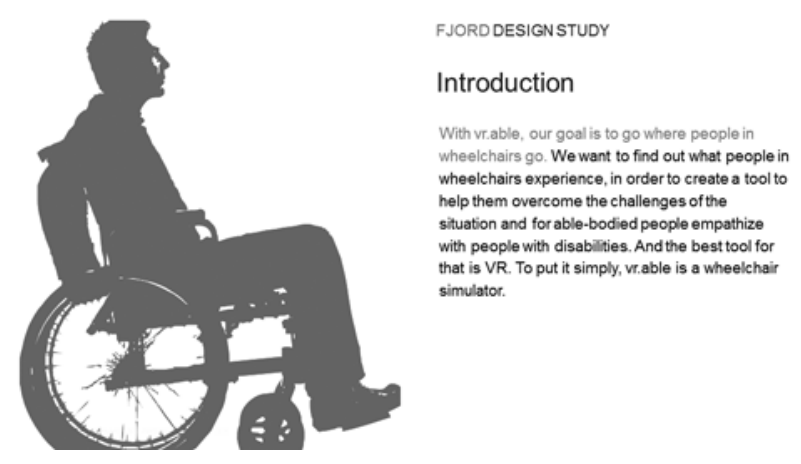

For Fjord, Student B was (thus far) the most fully formed as a collaborator in the Design Study week. Student B immediately started to develop more detailed explorations. Fjord's teaching process was less about fundamental design thinking exercises and more about pushing Student B to gain insights more quickly. Student B may have gotten less out of the immersion process, but the study had great success and subsequent traction. Although Fjord was already looking at a virtual reality experience of the use of wheelchairs in urban space, Student B brought his own, unique approach to it and pushed the project further. Following this Design Study, many Fjord design teams worked on the virtual reality wheelchair project, partly because there was a lot of interest in the virtual reality wheelchair study already. As a result, the studio team produced a full-fledged prototype. Student $\mathrm{C}$ was one of the youngest, but nevertheless an ambitious Design and Technology graduate student; she had received a full scholarship and ultimately became the valedictorian of the MFA in Design and Technology Program's graduating class. She tells the story of her experience in the Fjord/Parsons Immersion Program:

The first couple of days, I spent my time ideating with Roman and John thinking about different ways to explore consumer notions of privacy and security. We were trying to understand the nuances about how consumers felt when sharing their sensitive information. In the first two days, we created a hierarchy of sensitive information. The test was simple: in exchange for varying levels of information, we'd give users a nice glass of lemonade; a larger size for more information. If consumers were willing to share extra-sensitive information, like a thumbprint, we'd give them a cookie. We designed the test on Wednesday, conducted the test on a busy street corner on Thursday, and analyzed the results of the test in a Friday workshop. 


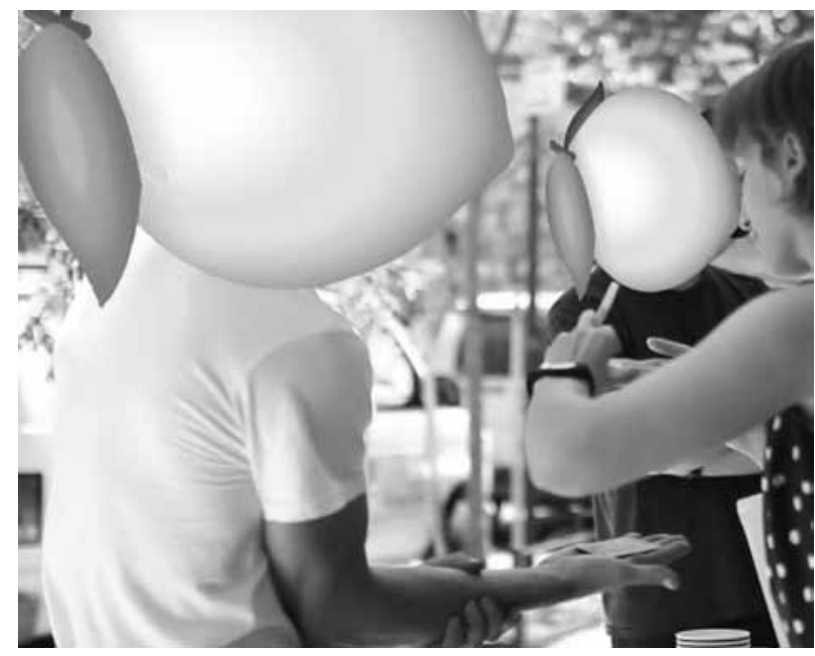

Data Privacy Lemonade Stand

Student $\mathrm{C}$ had many ideas from the start, and even had a structure for how she wanted to put it together. John challenged her initial ideas and framework by providing the Design Study questions, "How do people value their privacy?" and "How would you explore it?" This study raised compelling insights and questions. For example, once the value of our personal/private data is established, should there be an opportunity to create a personal economy out of the data? John postulates that people should sell their own data, rather than allow Facebook to have it and sell it, without any form of return to the creator(s). What would the structure of a personal economy look like? Instead of presenting a formal report of findings at the study's conclusion on Friday, this Design Study team organized a workshop with studio creatives to build on the idea further. This was a strong and difficult brief, yet the Fjord creative team and Student $\mathrm{C}$ worked well together, and Fjordians are still praising this Design Study today.

Because of the pre-interviews and multiple design studies in progress, some of the student and team matches were particularly successful. For example, Student $\mathrm{C}$ had already done quite a bit of research about the topic of data privacy before Anezka selected her for the study. She had already been analyzing a range of privacy policies and this previous work created an excellent fit with the Fjord team, thus deepening the student's learning and overall experience.

The next candidate, Student E, had experience in branding design. As opposed to the students that preceded her, Anezka made the decision to expose her to the experience near the end of her graduate studies. What set this student apart immediately was her ability to prototype in the Makeshop -and that she was someone who is not afraid to experiment. The Design Study question for Student E was to analyze traffic and people's activities in a specific space. What are people doing there? Without mounting cameras for tracking peo- 
ple in space, Student E came up with a method of mapping people in the space by hand: a paper-based "heat-map" that showed where people were dwelling or standing. This technique is what Student E learned from William Whyte's Social Life of Small Urban Spaces (1980). The Design and Technology graduate students often use this tool to analyze urban (exterior) space. Student E spent a lot of time performing the analysis before developing the concepts that she and the team thought would help activate the space in a different way. The Design Study then asked, "What should the people do in the space?" For example, if people walking by a coffee shop need to have awareness about something, should the coffee shop employees wear a t-shirt with an imprinted message? What do people do while sitting at the tables? What about the people who work in the space all day?

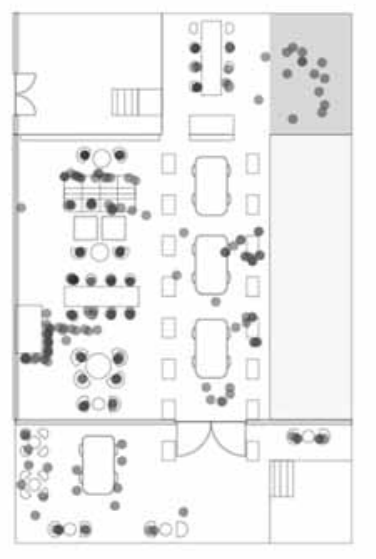

\title{
EVIDENCE
}

\author{
$45-50 \% \quad 31 \%$ \\ Were there for coffee $\quad$ Spent $<5$ minutes \\ $17 \% \quad 26 \%$ \\ Came in to explore Say longer than 1 hour
}

Student $\mathrm{E}$ began the challenge by talking to the people in the space. The whole team then came up with base-level behavioral insights. The student then mocked up the concepts such as the signage on the tables to show what was happening in the space and signage in the window that created awareness; she designed the messaging that would go into the space. The space owners (who were unaware of their customers' behaviors) were presented with the study's findings and incorporated them into their business.

Student E's unafraid and proactive spirit made a big difference in the work she performed. Roman remarked:

This is a quality that we look for in all of our designers. At Fjord, every product is different. Every business, every scenario, everything is different, and I think there should be a fearlessness to jump right in there and get into it. I think people who have that [quality] thrive particularly well in this Immersion Program. It is not necessarily a requirement to do good work in the structure, but the 
people who really shine have that [drive]. There are other people who are a bit slower to come to it, who are a little more nervous about it, or have discomfort with it. Others ease into it and do some amazing work. Certainly, in the oneweek format, the less time you spend easing in, the better.

Soon after Student E completed her graduate studies in the Design and Technology Program, Fjord hired her. Speaking with Student E recently, she said that working at Fjord for one week doesn't "hold a candle" to what she currently experiences and knows about service design as a full-time designer with Fjord. Student E did not know which aspect of the industry she wanted to work in and it was fortunate that the Immersion Program at Fjord coincided with the completion of her graduate studies at Parsons.

\section{Design Studies as Learning/Teaching Environment}

While these examples of participants' work yielded results that were productive for the Fjord creative team and for the students, Student D provided much more of an opportunity for the Design Studies process to become a teaching experiment. Student D was an experienced business consultant looking to expand her creative technology skills through the MFA in Design and Technology Program. The chosen theme for the student's Design Study was "communicating personality."

Student D initial assumptions about the topic were limiting, so Roman gently encouraged Student D into exploring the ideas of personality more closely. The lesson she learned was that design is about problem solving. The Design Study team experimented by enacting a scenario as a study of personality, and by playing with improvisational interactions to make people become more present to a situation. Through the experimentation, Student $\mathrm{D}$ and her team discovered people can be slowed down to concentrate more in the moment if they are presented with words and pictures that don't match (rather than words and pictures do match). The student's own assessment of the process did not reflect that she necessarily understood the value of the subtle outcomes of these experiments. John believes that the best outcome of Student D's Design Study is that it provided a good foundation for future studies, thus providing Fjord with valuable research questions. As Student D noted:

My project was a huge, huge topic, but the beauty of the way [John and Roman] work is that we always regrouped multiple times to look at what I had accomplished during the day and approach the question/topic/project with curiosity and new eyes. We redefined the question constantly and we made the material useful and the work meaningful. Nothing was discarded as a waste of time. It was all usable.

Roman kept asking me the hard questions and pushing me further. I trusted him and appreciated him absolutely. The principles I learned from Roman and John were the positive outcomes more so than any answers I got from the 
project. The time I spent talking to Roman and John about their work, their approach, the way they think, what they do, how they handle "failure," what they are looking for, how to stay open, how to stay curious, how not to be too precious about your ideas. Their wisdom and experience were very inspiring. All of that was more valuable to me than the actual results of my project.

Student F, a graphic designer, was placed in a study that was already in progress. The study's aim was to work on a methodology of a three-frame storyboard structure and to extend the work that Student $\mathrm{E}$ and the creative team had begun. It is apparent from Student F's comments that she was more in a position of observing a process that was already in place, rather than being a fully contributing member of the team. However, she felt the observation process was a beneficial and positive outcome. Although Fjord gave her less agency to control the process than other Immersion Week students, the company's team felt she still learned a lot from what may have seemed to be a chaotic process. Student $F$ felt the same and stated:

The goal for the week was to tell the story of one of the designer's products -a scarf- and how it would be distributed to benefit an organization. For our first prototype, we worked on how we would tell the story through text and images that were displayed vertically or horizontally. We user-tested to see which images and what amount of text told the story, and to which layout people gravitated. For our second prototype, we set up a display with a body form wearing the scarf and images and set we selected. For our third prototype, we created a display at the entrance of the firm and asked individuals to test out the display with three design options with different interactions. We followed up with questions to find out which design was the simplest and told our story.

On my last day, we did user tests on a different floor [of the building under study] with people who were unfamiliar with the project, and we received additional feedback. We were successful in user testing the display, communicating the story behind the scarf and the level of engagement.

The positive outcome was working with a collaborative team. There was a level of freedom to user test to make sure we were on the right track. There was no one saying, "We do it this way" or "We don't do that." The feedback we received from the user testers provided us with interesting and unexpected information. I was able to see user testing implemented and its benefits. 
(1) What orientation of the imagestell the story.
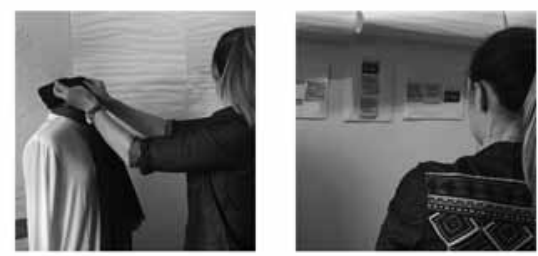

We warted to know the following:

What series of images are they drawn to first? Does the uses stan from the len and go to the rige? Recreate the story?

Explain why did they place the images vertically or horizontally
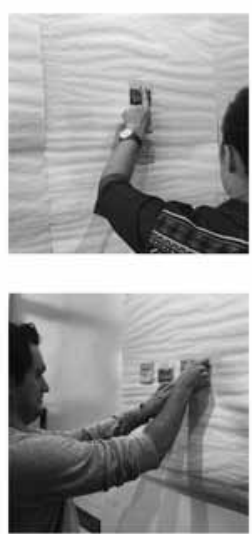

\section{Conclusion}

The Design Study Immersion Week projects are primarily centered on the opportunities created for Fjord as a learning company and for Parsons students in the Design and Technology MFA Program to gain professional service design experience. The contradiction and paradox that comes with the need for ambidexterity in Fjord's exploitative and exploration endeavors that propel the company further revealed itself as a great opportunity for Parsons students as they learn about the research and prototyping processes in a service design company. The short timeline and use of behavioral exploration research areas outside of client work simplify the engagement for the company as it removes potential confidentiality issues. These weekly design project challenges also encourage teams to think outside the day-to-day studio interactions and find new ways to explore. Placing Parsons students into this open exploration brings fresh thinking to the Fjord team members and allows the student to see more established service design methods. It also grants the student an opportunity to quickly connect with a working design team, which is often difficult to do in longer internship programs.

For Fjord, the benefits of Design Studies are clear. There are new insights attached to existing and emerging human behaviors that promote positive change. These insights become rationale for the ways Fjord designs new products and services for clients, thereby creating an opportunity for Fjord to turn employee's "bench" or idle time into paid services. Engaging students in the process ensures Fjord applies fresh methods and thinking. Reciprocally, the students benefit from immersion in a professional setting where they can experience the full spectrum of service design and human-centered research processes; these range from asking provocative questions, to developing prototypes and experiments, 
to performing user-tests, to gaining insights that generate new knowledge about human behavior.

At Parsons, the future "dream" for this immersion process would be for the Design and Technology graduate students to have four or five of these experiences with different companies in a variety of industries. The Immersion Program experiences are valuable as a way to learn and teach from research studies that then can become the currency of an innovation company.

\section{References}

Andriopoulos, C., \& Lewis, M. W. (2010). Managing innovation paradoxes: Ambidexterity lessons from leading product design companies. Long Range Planning, 43, 104-122. Atlanta, GA: Elsevier Publishing.

Hao, K. (2017). Designers at Fjord built a vr system that teaches first time wheelchair users. Retrieved from http://designers-at-fjord-built-a-vr-system-that-teaches-first-timewheelchair-users-how-to-navigate-city-environments/

Jensen, S., Kalantari, R., \& Venstad, G. (2016). Fjord makeshop owls creating community. Retrieved from https://www.fjordnet.com/conversations/fjord-makeshop-owls-creatingcommunity-in-a-global-workplace/

Kelley, T., \& Littman, J. (2006, 2008). The ten faces of innovation: Strategies for heightening creativity. New York: Crown Publishing Group.

Osborne, A. F. (1979). Applied imagination: Principles and procedures of creative problem solving (3rd ed.). New York: Charles Scribner's Sons.

Perlin, R. (2012). Intern nation: How to earn nothing and learn little in the new brave economy. Brooklyn, New York: Verso Books.

Schön, D. (1982/83). The reflective practitioner: How professionals think in action. New York: Basic Books.

Webber, R., \& Webber, M. (1973). Dilemmas in a general theory of planning. Working Papers Urban and Regional Development. Berkeley, CA: University of California, Berkeley. Whyte, W. (1980). The social life of small urban spaces. New York: Project for Public Spaces, Inc.

Resumen: Desde 2015, Fjord and Parsons School of Design han estado colaborando para crear una alternativa mutuamente beneficiosa para el sistema de pasantías, al sumergir a los estudiantes de posgrado en Diseño y Tecnología en los Estudios de Diseño Inmersivo de Fjord, durante una semana. Los Estudios de Diseño en Fjord operan desde el trabajo directo con el cliente y son un vehículo perfecto para involucrar a los estudiantes en la investigación de diseño estructurado, centrado en el ser humano. La misión del programa de inmersión Fjord / Parsons es influir en el futuro del diseño, dar forma a los futuros diseñadores y propulsar la innovación en el diseño de servicios de Fjord. Para los estudiantes de Parsons, la experiencia como miembros contribuyentes de un equipo de diseño de servicios es un beneficio inusual. Mientras que los programas de pasantías tradicionales 
de meses pueden ser una carga para los recursos de la compañía o una experiencia de aprendizaje improductiva para los estudiantes, el Programa de inmersión Fjord / Parsons es una excelente oportunidad y una alternativa de capacitación para involucrar a los estudiantes en un trabajo significativo, logrando así una investigación valiosa de diseño para Fjord. Este documento analiza seis casos de estudiantes graduados de Parsons que se beneficiaron con este programa.

Palabras clave: Repensando pasantías - práctica de diseño - investigación de diseño - pensamiento de diseño - estudio de diseño - diseño de servicios.

Resumo: Desde 2015, a Fjord e a Parsons School of Design têm colaborado para criar uma alternativa mutuamente benéfica ao sistema de estágio, ao imergir estudantes de pós-graduação em Design e Tecnologia nos Immersive Design Studios da Fjord por uma semana. Os Estudos de Design no Fjord operam a partir do trabalho direto com o cliente e são um veículo perfeito para envolver os alunos em pesquisas de design estruturado, centradas no ser humano. A missão do programa de imersão Fjord / Parsons é influenciar o futuro do design, moldar futuros designers e impulsionar a inovação no projeto dos serviços da Fjord. Para os alunos da Parsons, a experiência como membros contribuintes de uma equipe de design de serviço é um benefício incomum. Embora os programas tradicionais de estágio de meses possam ser um fardo para os recursos da empresa ou uma experiência de aprendizado improdutiva para os alunos, o Programa de Imersão Fjord / Parsons é uma excelente oportunidade e um treinamento alternativo para envolver os alunos. em um trabalho significativo, conseguindo assim uma valiosa pesquisa de design para a Fjord. Este documento analisa seis casos de estudantes de pós-graduação da Parsons que se beneficiaram deste programa.

Palavras chave: Repensar estágios - prática de design - pesquisa de design - design thinking - estudo de design - design de serviços.

[Las traducciones de los abstracts fueron supervisadas por el autor de cada artículo] 



\section{Currículum Vitae completo de los autores Full versión of author's biographies \\ Presentados por orden alfabético Presented in alphabetical order}

María Florencia Bertuzzi. Diseñadora Textil y de Indumentaria (UP, 2012). Desde el año 2013 se desempeña como docente universitaria (UP y UNNOBA). Cursó el Programa de Formación y Capacitación Docente (UP). Actualmente se encuentra cursando un Posgrado de Especialización en Docencia Universitaria (Unnoba). Participa como coordinadora de una feria de diseño en Junín, Buenos Aires y se encuentra desarrollando un proyecto de lencería de diseño independiente.

Mercedes Buey Fernández. Diseñadora Industrial (UP). Profesora de la Universidad de Palermo en el Área de Diseño de Objetos y Productos de la Facultad de Diseño y Comunicación desde 2012. A lo largo de su trayectoria se desempeñó como diseñadora senior y semi senior en diferentes empresas.

Desde 2012 es socia gerente, diseñadora y fundadora de Estudio De Raíz S.R.L. y Yerba Mate Mathienzo, fue docente evaluadora de Proyectos de Graduación; es especialista en Gestión de Diseño (UBA) y asistente externa en el área de estudios ergonómicos y capacitaciones de diferentes empresas.

Marie Geneviève Cyr is an Assistant Professor in the BFA Fashion Design program at Parsons School of Design. She has an MA in Visual Culture/Fashion Theory from New York University, a BA in Design and Applied Arts from the Edinburgh College of Art and a degree in Fashion Design from the College Marie-Victorin. Marie Genevieve Cyr was then nominated in 2009, for a Genie Award by the Academy of Canadian Cinema and Television for "Best Costume Design" for the feature film, "Who is KK Downey?". Her work has been exhibited internationally, and focused sculptural forms that examine emotions, history, and materiality. As an educator, Marie Geneviève values the importance of developing research methods that drive innovative cross-disciplinary design practice via $2 \mathrm{D}$ and $3 \mathrm{D}$ investigation. She pushes the students to develop their own personal intellectual expression through unique non-linear approaches. Her research explores the intersections between national, rural and urban identities, examining the politics of abstract desire, hyper-realistic landscape, and the notion of fantasy.

Juan Alberto Di Loreto. Licenciado en Ciencias de la Comunicación (UBA) y Bibliotecario (Biblioteca Nacional Mariano Moreno), ejerció como docente en Comunicación y Ciencia Política (UBA). Con el foco puesto en el cruce entre el arte, la comunicación y la filosofía colaboró en periódicos y revistas de Buenos Aires y el interior. Actualmente se desempeña como Bibliotecario en la Universidad de Palermo. 
Claudio Eiriz. Músico, Psicopedagogo, Licenciado y Profesor en Ciencias de la Educación (UNLZ), Posgraduado en Semiología de la Música (UBA). Áreas de interés: Análisis de las relaciones entre la imagen y el sonido; Aculogía; Didáctica de la Música y Semio-Epistemología. Profesor de la Facultad de Diseño y Comunicación de la Universidad de Palermo, de la Facultad de Psicología de la Universidad Abierta Interamericana, de la Facultad de Psicología de la Universidad de Buenos Aires y de la Facultad de Kinesiología y Fisioterapia de la Universidad Juan Agustín Maza de Mendoza.

Daniela Escobar. Diseñadora Textil y de indumentaria (UP, 2011). Asesora de imagen personal y corporativa (COE, 2009). Cursó el Programa de Formación y Capacitación Docente (UP, 2014). Profesora de la Universidad de Palermo en el Área de Moda y Tendencias de la facultad de Diseño y Comunicación.

Desde el año 2011 se desempeña como diseñadora de indumentaria y modelista independiente. Participa activamente del diseño de vestuario para cortos independientes.

Actualmente dirige su propia marca de Diseño de Alta Costura. Forma parte del Equipo de Evaluación de Proyectos de Graduación y el Cuerpo Académico de Tutorías de la facultad de Diseño y Comunicación de la Universidad de Palermo.

Steven Faerm is an Associate Professor of Fashion Design at Parsons School of Design (Program Director, BFA Fashion Design, 2007-2011). A Parsons alumnus (94') and Designer of the Year Nominee, he began teaching in 1998 while working for designers such as Marc Jacobs, Donna Karan, and Kenneth Richard. He has been recognized for his teaching by winning "The University Distinguished Teaching Award" and The School's “Teaching Excellence Award."

Steven has created college- and pre-college programs and courses for Parsons and other leading international institutions, and has served on academic review boards for Rhode Island School of Design, Pratt Institute, Virginia Commonwealth Institute (VCU), Otis College of Art and Design, and Marist College. He has taught and lectured for institutions including Harvard University, Massachusetts Institute of Technology (MIT), Brown University, Donghua University in Shanghai, The University of Palermo (UP) in Buenos Aires, and The Spero Villioti School in South Africa. Since 2012, he has co-produced an academic journal dedicated to design education between Parsons and UP.

His publications include two books that are featured on international college-level required reading lists and available in seven languages: Fashion Design Course: Principles Practices, and Techniques and Creating a Successful Fashion Collection: Everything You Need to Develop a Great Line and Portfolio. He is currently writing a third book about design education and pedagogy while publishing ongoing research studies in academic journals and serving as a consultant for five publishing houses.

Areas of scholarship and research included the future of art and design education, pedagogy, and student development.

Verónica Fiorini. Magister en Diseño Comunicacional (DICOM) de la FADU UBA. Diseñadora de Indumentaria (UBA). Especialista en Gestión Estratégica de Diseño - Gerenciamiento de Proyecto y de Diseño Comunicacional. Magister en curso de la maestría 
DICOM (UBA). Profesora de la Universidad de Palermo en el Área de Moda y Tendencia en la Facultad de Diseño y Comunicación. Actualmente trabaja como diseñadora en su propia marca. Tiene varias publiciaciones: "Del diseño al producto", capítulo del libro Desing de Moda, diversos olhares; "Diseño de indumentaria, aspectos conceptuales y metodológicos. Armado de colección" en Cuadernos de Cátedra FADU-UBA 2009; "Acerca del Método" en Revista Contextos de la UBA; entre otros.

Ver desfiles de la Cátedra de Verónica Fiorini en Moda en Palermo.

Pertenece a la Facultad de Diseño y Comunicación desde el año 2011.

Carmen Inés Galbusera Testa. Arquitecta Universidad de Belgrano 1980. Docente CBCFADU-UBA 1985/actualidad. Docente Facultad Diseño y Comunicación Universidad de Palermo 2003/actualidad. Especialista en Docencia Universitaria FADU-UBA 2017. Especialista en Gestión Ambiental Metropolitana GAM-FADU-UBA 2015. Maestranda GAMFADU-UBA. Investigadora PUC-FADU-UBA 2016/actualidad.

Ximena González Eliçabe. Diseñadora Textil (UBA). Artista e investigadora de las tradiciones textiles americanas.. Es Profesora de la Universidad de Palermo en el Departamento de Diseño de Modas de la Facultad de Diseño y Comunicación. Es consultora y capacitadora en temas de diseño y artesanía, trabajando en programas de instituciones públicas como el Ministerio de Turismo de la Nación, el Consejo Federal de Inversiones y otras. Realizó exposiciones y obtuvo diversos premios y menciones. Es directora académica del Centro de Estudios Latinoamericanos La Abadía, Bs. As. Curó la muestra "Ponchos en el Bicentenario", en el Museo de Arte Popular José Hernández, Bs. As. Es Directora de contenidos de ArgentinaXplora.com. En su actividad en la Universidad de Palermo publicó: "Arte, Diseño y artesanía. La metáfora textil como signo de identidad (2005), "Experimentación, innovación, ciencia y diseño" (2006), Diseño, educación y preservación del patrimonio cultural (2006), "Introspección, el cuerpo" (2009). "Arte Textil y Tradición en la Prov. de Catamarca, Noroeste argentino" (2012). "Arte sartorial, de lo ritual a lo cotidiano" (2013), "El Tiempo y la materia, atributos del nuevo lujo" (2016).

John Jones, Design Strategy Lead Fjord, New York. John Jones believes in the power of simplicity. He is passionate about understanding complex systems and working with clients to bring out the simple solution inside. As SVP Design Strategy at Fjord, John helps clients engage audiences in new ways with services that span mobile, web and physical spaces. John has a 20-year history creating award-winning digital products and experiences for some of the world's best-known brands. Past and current projects span multiple outlets and consumer-driven arenas, including retail, digital, mobile, games, e-commerce and outdoor. Previously, John was SVP, Executive Creative Director at R/GA where he founded R/GA's Global Retail and Digital Environments practice and the R/GA LAB, an exploration and workshop space dedicated to consumer insights and new methods of interaction for in-store, mobile, online and branded environments. The lab "build to think" iterative design process resulted in hundreds of innovations for clients and many 'firsts' in Times Square, retail spaces and mobile platforms. His work has been featured in many industry publications and has won almost every major design award. He is a frequent speaker on 
panels and industry events and has taught in the graduate design and technology department at the Parsons School of Design in New York City.

María del Mar Ketlun. Diseñadora Gráfica (UBA) Facultad de Arquitectura, Diseño y Urbanismo. Docente en Medios Expresivos. Cátedra Feller (UBA) Facultad de Arquitectura, Diseño y Urbanismo. Miembro del equipo de Evaluación de Proyectos de Graduación de la Facultad de Diseño y Comunicación (UP). Docente en Introducción al Lenguaje Visual I en la Facultad de Diseño y Comunicación (UP). Profesora de la Universidad de Palermo en el Área de Diseño Visual en la Facultad de Diseño y Comunicación. Fundó y trabajó en Universal Brands y Oh! que Agencia como Directora Online y Directora de Arte. Trabajó en otros estudios y agencias como directora de arte y creativa. Dictó clases en otras instituciones.

Victoria Martinez Azaro. Graduada en la Universidad de Auckland, Nueva Zelanda con una Maestría en Bellas Artes; Licenciatura en Bellas Artes con especialización en Diseño de Indumentaria, Whitecliffe College of Art and Design, Nueva Zelanda; Certificado en Comunicación en Moda, London College of Fashion, Inglaterra. Docente en el Departamento de Diseño de Moda en la carrera de grado y Maestría, Whitecliffe College of Art and Design, Nueva Zelanda. A lo largo de su trayectoria se desempeñó como artista plástica en el área de moda y textiles, trabajo como diseñadora, compradora de indumentaria, jefa de prensa y productora de moda en diferentes empresas en Argentina y en Nueva Zelanda.

Laura Mastantuono. Licenciada en Comunicación Audiovisual (Universidad de Palermo) Trabaja de manera independiente en el área de realización audiovisual, ha sido parte de largometrajes y cortometrajes documentales y ficcionales en Argentina, Colombia y España. Los proyectos han sido seleccionados en festivales alrededor del mundo, entre ellos el Festival de Cannes. Colabora en producciones de comunicación institucional para empresas digitales, y se desempeñó como gerente de contenido y edición. Dentro del área de investigación escribe para diversos medios online en inglés y español, y trabajó, dentro de un programa de voluntariado, en el Museo del Cine de Buenos Aires, restaurando y catalogando el archivo de nitrato y acetato. Desde el año 2014 forma parte del equipo docente de la Universidad de Palermo.

Noël Palomo-Lovinski is an Associate Professor at Kent State University in Ohio. She received her B.F.A. in Fashion Design from Parsons School of Design, M.A. in Visual Culture from New York University, and M.F.A. in Textiles from Kent State University. Noël's research focus concerns design responsibility and sustainable practice, future needs of fashion design education, and the relationship between culture and design.

Anezka Sebek, Ph.D. Associate Professor of Media Design Parsons School of Design. Anezka designs curricula in BFA/MFA Design and Technology Programs in virtual, augmented and mixed reality technologies, as well as teaching in studio and thesis courses. Before teaching full-time, her extensive career in the film industry includes projects for television, advertising, documentaries and feature films. She was best known as visual effects and computer animation producer for technologically complex projects that combined live- 
action with digital effects. She has written, produced, and directed music videos, narrative shorts, and documentaries. Ms. Sebek served on juries for Association for Computing Machinery Siggraph Electronic and Animation Theater and Ars Electronica (Linz, Austria). She was invited to speak at the Post-City Ars Electronica Festival Expanded Animation Panel (2015) about the changing field of new media and animation technologies. She recently curated the New School Nth Degree series Immersive Storytelling Symposium (February 2017). Her Ph.D. in Sociology (2016) dissertation, Family Homelessness in the Small City (2016), is an ethnographic qualitative methods study of the social strata and bureaucracies that control the lack of affordable housing and living-wage jobs in postindustrial Northeast American cities.

Marcia Veneziani. Doctora en Comunicación Social y Licenciada en Publicidad (USAL). Profesora de la Universidad de Palermo en el Área de Investigación y Producción de la Facultad de Diseño y Comunicación. Es autora de los libros La Imagen de la Moda, y Moda, Economía y Sociedad. Además de escribir numerosos ensayos sobre comunicación, ha coordinado publicaciones académicas internacionales con la Universidad de Palermo y la Università di Bologna, y Parsons The New School for Design, entre otras. Especialista en temas de comportamiento de Moda y Consumo. Miembro del Comité Editorial de la Revista ZoneModa Journal, dedicada a los estudios de moda en Italia, Universitá di Bologna, Italia, desde julio de 2013. Directora de las Jornadas de Moda y Pensamiento: "Hipermoda”. Fundación Ortega y Gasset Argentina (2015) y miembro del staff del Centro de Estudios Latinoamericanos La Abadía y del Centro de Diplomacia Karina Vilella. Ha sido Profesora Titular en la Maestría en Comercialización y Comunicación Publicitaria de la Universidad del Salvador. También se desempeñó en importantes agencias de publicidad, organizaciones educativas y ha colaborado con diversos medios de comunicación y prensa en temas que tratan sobre su especialidad. Pertenece a la Facultad de Diseño y Comunicación desde el año 2009. Forma parte del Cuerpo Académico del Doctorado en Diseño, de la Maestría en Gestión del Diseño y del Equipo de Evaluación de Proyectos de Graduación. Miembro del Plenario de la Comisión de Posgrado DC. Dirige la Línea de Investigación Nuevos Paradigmas en la Enseñanza de la Moda y el Diseño.

Thomas Werner is the author of the upcoming book The Fashion Image for Bloomsbury Press, London (Jan 2018), and an Editor at Large for IRKmagazine, a Paris based fashion and culture magazine and web site. An Assistant Professor and past Photography Program Director at Parsons School of Design in New York, Thomas currently lectures internationally on topics of photography, fashion, education, and contemporary professional practices. He is also the former owner of Thomas Werner Gallery in Manhattan's Chelsea Art District, and recently lead a team developing a media and literacy web site and resource center in five languages, Spanish, French, Russian, Arabic and English for the United Nations Alliance of Civilizations/UNESCO. Werner has worked with the Department of State on cultural projects in Russia, and been a photography consultant for $\mathrm{COACH}$ and Rodale Publishing, among others. He has been a recurrent instructor at the United Nations Education First Summer School, and is presenting workshops on effective message development and visual communication on an international basis. 
Over the last 10 years his research work has been Russia centric spending an average of 70 days a year there partnering with 32 cultural, educational, and governmental organizations to develop projects in 29 cities. The focus has been the introduction of contemporary education methodologies, and the development of creative cultures within the country. Russian partners have included; The State Hermitage Museum, the National Center of Contemporary Art, Perm Regional Government, The Moscow Biennale for Young Art, National Centre of Photography for the Russian Federation, The Central State Archive of Film, Photographic and Phonographic Documents, The Pro Arte Foundation, and others. He has curated exhibitions in the United States and abroad, including seven co-curated exhibitions at the State Hermitage Museum in Saint Petersburg, Russia. His private collection of Russian photographs and artifacts, have been exhibited internationally. 


\section{Publicaciones del Centro de Estudios en Diseño y Comunicación}

El Centro de Estudios en Diseño y Comunicación de la Facultad de Diseño y Comunicación de la Universidad de Palermo desarrolla una amplia política editorial que incluye las siguientes publicaciones académicas de carácter periódico:

\section{- Cuadernos del Centro de Estudios en Diseño y Comunicación [Ensayos]}

Es una publicación periódica que reúne papers, ensayos y estudios sobre tendencias, problemáticas profesionales, tecnologías y enfoques epistemológicos en los campos del Diseño y la Comunicación.

Se publican de dos a cuatro números anuales con una tirada de 500 ejemplares que se distribuyen en forma gratuita.

Esta línea se edita desde el año 2000 en forma ininterrumpida, recibiendo colaboraciones remuneradas, dentro de las distintas temáticas.

La publicación tiene el número ISSN 1668.0227 de inscripción en el CAICYT-CONICET y tiene un Comité de Arbitraje.

- Creación y Producción en Diseño y Comunicación [Trabajos de estudiantes y egresados] Es una línea de publicación periódica del Centro de Producción de la Facultad. Su objetivo es reunir los trabajos significativos de estudiantes y egresados de las diferentes carreras. Las producciones (teórico, visual, proyectual, experimental y otros) se originan partiendo de recopilaciones bibliográficas, catálogos, guías, entre otros soportes.

La política editorial refleja los estándares de calidad del desarrollo de la currícula, evidenciando la diversidad de abordajes temáticos y metodológicos realizados por estudiantes y egresados, con la dirección y supervisión de los docentes de la Facultad.

Los trabajos son seleccionados por el claustro académico y evaluados para su publicación por el Comité de Arbitraje de la Serie.

Esta línea se edita desde el año 2004 en forma ininterrumpida, recibiendo colaboraciones para su publicación. El número de inscripción en el CAICYT-CONICET es el ISSN 16685229 y tiene Comité de Arbitraje.

\section{- Escritos en la Facultad}

Es una publicación periódica que reúne documentación institucional (guías, reglamentos, propuestas), producciones significativas de estudiantes (trabajos prácticos, resúmenes de trabajos finales de grado, concursos) y producciones pedagógicas de profesores (guías de trabajo, recopilaciones, propuestas académicas).

Se publican de cuatro a ocho números anuales con una tirada variable de 100 a 500 ejemplares de acuerdo a su utilización. 
Esta serie se edita desde el año 2005 en forma ininterrumpida, su distribución es gratuita y recibe colaboraciones para su publicación. La misma tiene el número ISSN 1669-2306 de inscripción en el CAICYT-CONICET.

\section{- Reflexión Académica en Diseño y Comunicación}

Las Jornadas de Reflexión Académica son organizadas por la Facultad de Diseño y Comunicación desde el año 1993 y configuran el plan académico de la Facultad colaborando con su proyecto educativo a futuro. Estos encuentros se destinan al análisis, intercambio de experiencias y actualización de propuestas académicas y pedagógicas en torno a las disciplinas del diseño y la comunicación. Todos los docentes de la Facultad participan a través de sus ponencias, las cuales son editadas en el libro Reflexión Académica en Diseño y Comunicación, una publicación académica centrada en cuestiones de enseñanza-aprendizaje en los campos del diseño y las comunicaciones. La publicación (ISSN 1668-1673) se edita anualmente desde el 2000 con una tirada de 1000 ejemplares que se distribuyen en forma gratuita.

\section{- Actas de Diseño}

Actas de Diseño es una publicación semestral de la Facultad de Diseño y Comunicación, que reúne ponencias realizadas por académicos y profesionales nacionales y extranjeros. La publicación se organiza cada año en torno a la temática convocante del Encuentro Latinoamericano de Diseño, cuya primera edición fue en Agosto 2006. Cabe destacar que la Facultad ha sido la coordinadora del Foro de Escuelas de Diseño Latinoamericano y la sede inaugural ha sido Buenos Aires en el año 2006.

La publicación tiene el Número ISSN 1850-2032 de inscripción y tiene comité de arbitraje.

A continuación se detallan las ediciones históricas de la serie Cuadernos del Centro de Estudios en Diseño y Comunicación:

\section{Cuadernos del Centro de Estudios de Diseño y Comunicación [ ISSN 1668-0227 ]}

$>$ Cuadernos del Centro de Estudios en Diseño y Comunicación. [Ensayos]: Cine e historia. Representaciones fílmicas en un mundo globalizado. Zulema Marzorati y Mercedes Pombo: Prefacio | Eje 1: Etnicidades en la pantalla: Tzvi Tal: Brechas y etnicidad. Personajes judíos violentos en películas de Argentina, Uruguay y Venezuela I Alejandra F. Rodríguez: ¿Dónde está el sujeto?: problemas de representación de los pueblos originarios en el cine | Eje 2: Construyendo la historia: Mónica Gruber: Medios y poder: 1984 | Adriana A. Stagnaro: Lo imaginario y lo maravilloso de Internet. Una aproximación antropológica I Zulema Marzorati y Mercedes Pombo: Humanismo y solidaridad en El puerto (Kaurismäki, Finlandia/Francia/ Alemania, 2011) | Eje 3: Cine, historia y memoria: María Elena Stella: Holocausto y memoria en los tiempos de la globalización. Representaciones en el cine alemán | Claudia Bossay P.: Libertadores; bicentenarios de las independencias en el cine I Marta N. R. Casale: La imagen faltante, de Rithy Panh, testigo y cineasta. El genocidio en primera persona. (2019). Buenos Aires: Universidad de Palermo, Facultad de Diseño y Comunicación, Centro de Estudios en Diseño y Comunicación. Vol. 77, diciembre. Con Arbitraje. 
$>$ Cuadernos del Centro de Estudios en Diseño y Comunicación. [Ensayos]: Moda, Diseño y Sociedad. Laura Zambrini: Prólogo | Carlos Roberto Oliveira de Araújo: Metamorfose Corporal na Moda e no Carnaval I Analía Faccia: Discursos sobre el cuerpo, vestimenta y desigualdad de género I Griselda Flesler: Marcas de género en el diseño tipográfico de revistas de moda | Jorge Leite Jr:: Sexo, género y ropas I Nancy de P. Moretti: La construcción del lenguaje gráfico en el diseño de moda y la transformación del cuerpo femenino I María Eugenia Correa: Diseño y sustentabilidad. Un nuevo escenario posible en el campo de la moda | Gabriela Poltronieri Lenzi: O chapéu: Uma ferramenta para a identidade e a responsabilidade social no câncer de mama | Taña Escobar Guanoluisa y Silvana Amoroso Peralta: El giro humanista del sistema de la moda I Suzana Avelar: La moda contemporánea en Brasil: para escapar del Siglo XX | Daniela Lucena y Gisela Laboureau: Vestimentas indisciplinadas en la escena contracultural de los años 80 | Paula Miguel: Más allá del autor. La construcción pública del diseño de indumentaria en Argentina | Gianne Maria Montedônio Chagastelles: Arte y Costumbres: Los pliegues azules en los vestidos de vinilo de Laura Lima (1990-2010) I Patricia Reinheimer: Tecendo um mundo de diferenças. (2019). Buenos Aires: Universidad de Palermo, Facultad de Diseño y Comunicación, Centro de Estudios en Diseño y Comunicación. Vol. 76, diciembre. Con Arbitraje.

$>$ Cuadernos del Centro de Estudios en Diseño y Comunicación. [Ensayos]: Arte y Comunicación: Experiencias estéticas y el flujo del tiempo. N. Aguerre y M. Boivent: Prólogo I V. Capasso: Nuevas tramas socio-espaciales después de la inundación en la ciudad de La Plata: un análisis de experiencias artísticas y memoria colectiva I J. Cisneros: Operaciones de montaje y reescritura como huellas del tiempo en "Diagonal Cero" I V. de la Cruz Lichet: Hacia una taxonomía de la Memoria. Prácticas artísticas colombianas en torno a la reconstitución de hechos históricos I A.del P. Forero Hurtado, Y.A. Orozco y L.C. Rodríguez Páez: El presente y el irremediable pasado. La reconstrucción de lo público desde la música rap de la Alianza Urbana en Quibdó-Chocó, Colombia | F. Fajole: Mirtha Dermisache: La otredad de la escritura I E. García Aranguren: Vanguardias artísticas y videojuegos: retomar el pasado para el mercado futuro I L. Garaglia: "Cómo hacer palabras con cosas" | L. Gómez: El cine y esos pueblitos: Mediaciones culturales de la memoria nacional | B. Gustavino: Vanguardias, dependencia cultural y periodizaciones en lucha. La historización del arte argentino de los años '60 | F. Jaubet: Poesía de lo real en "Historia de un Clan" de Luis Ortega | C. Juárez y J. Lamilla: Prácticas sonoras desbordantes. El surgimiento del ciclo Experimenta97 en Buenos Aires I I. Mihal y M. Matarrese: Diversidad cultural y pueblos indígenas: una mirada sobre las TIC | C.D.Paz: De esta suerte se gobierna la mayor parte. La jefatura indígena examinada desde la intencionalidad performativa de la escritura etnológica de la Compañía de Jesús I M.E. Torres: Tiempos de Amor | C.Vallina y C. Vallina: Imagen y Memoria. (2019). Buenos Aires: Universidad de Palermo, Facultad de Diseño y Comunicación, Centro de Estudios en Diseño y Comunicación. Vol. 75, diciembre. Con Arbitraje.

$>$ Cuadernos del Centro de Estudios en Diseño y Comunicación. [Ensayos]: Artes Dibujadas: cartografías y escenas de la Historieta, el Humor Gráfico y la Animación. Laura Vazquez: Prólogo I Mara Burkart: La Guerra de Malvinas según las Caricaturas de Hermenegildo Sábat en Clarín I Laura Caraballo: La parodia y la sátira en la historieta 
transpositiva de Alberto Breccia | Alice Favaro: La "Beya" durmiente: entre reescritura y transposición I Amadeo Gandolfo: La historia interminable: Langostino y Mangucho y Meneca en Patoruzito (1945-1950) I Sebastian Gago: Desovillando tramas culturales: un mapeo de la circulación y el consumo de las historietas Nippur de Lagash y El Eternauta I Jozefh Queiroz: La crónica-historieta en Macanudo, de Liniers I Marilda Lopes Pinheiro Queluz: Logotipo ou quadrinho? As animadas aventuras de Don Quixote nas capas de Ângelo Agostini I Analia Lorena Meo: Anime y consumo en Argentina en las páginas de Clarín, La Nación y Página 12 (1997-2001) I Ana Pedrazzini y Nora Scheuer: Sobre la relación verbal-visual en el humor gráfico y sus recursos I Paulo Ramos: O enigma do número dois: os limites da tira em ambientes digitais I Roberto Elísio dos Santos: O Brasil através das histórias em quadrinhos de humor I Facundo Saxe: Jago de Ralf König: historieta sexo-disidente o cómo volver porno y queer a Shakespeare I Pablo Turnes: Breccia Negro: el testimonio de un autor I Laura Vazquez y Pablo Turnes: Contar desde los fragmentos. Rupturas, memoria y lenguaje en dos casos de la historieta argentina contemporánea | Aníbal Villordo: La imagen intolerable: Intensidad estética y violencia en el cómic de superhéroes I Máximo Eseverri: Víctor Iturralde Rúa y la especificidad de lo infantil. Un primerísimo primer acercamiento. (2019). Buenos Aires: Universidad de Palermo, Facultad de Diseño y Comunicación, Centro de Estudios en Diseño y Comunicación. Vol. 74, septiembre. Con Arbitraje.

> Cuadernos del Centro de Estudios en Diseño y Comunicación. [Ensayos]: Diseño en Perspectiva - Diseño para la transición. Primera Sección. D. V. Di Bella: Prólogo de la Primera Sección | T. Irwin: Prefacio Diseño para la Transición | D. Lockton and S. Candy: Un vocabulario para las visiones del diseño para las transiciones | G. Kossoff: Localismo cosmopolita: la red planetaria de la vida cotidiana dentro de lo local I A. İ. Gaziulusoy: Postales desde los límites: hacia los futuros del diseño para las transiciones sostenibles I C. Tonkinwise: (Des)órdenes del diseño: sistemas de mediación de nivel en el diseño para la transición | I. Mulder, T. Jaskiewicz and N. Morelli: Sobre la ciudadanía digital y los datos como un nuevo campo común: ¿Podemos diseñar un nuevo movimiento? | P. Scupelli: Enseñanza del diseño para la transición: un estudio de caso sobre Design Agility, Design Ethos y Dexign Futures | J. Boehnert: Diseño para la transición y pensamiento ecológico | T. Irwin: El enfoque emergente del diseño para la transición | T. Costa Gomez: Proyectos de transición en curso: una perspectiva del sur I S. Hamilton: Palabras en acción: Creando y haciendo el diseño para la transición en Ojai, California, un caso de estudio I Ch. L. Dahle: Diseñar para las transiciones: abordar el problema de la pesca excesiva en el mundo I S. Rohrbach and M. Steenson: Diseño para la transición: enseñanza y aprendizaje | M. A. Mages and D. Onafuwa: Opacidad, transición e investigación en diseño. (2019). Buenos Aires: Universidad de Palermo, Facultad de Diseño y Comunicación, Centro de Estudios en Diseño y Comunicación. Vol. 73, julio. Con Arbitraje.

$>$ Cuadernos del Centro de Estudios en Diseño y Comunicación. [Ensayos]: Convergencia pedagógica-digital: libros, lecturas y diseño. Ivana Mihal: Prólogo. Narrativa transmedia. Convergencia pedagógica-digital: libros, lecturas y diseño | Natalia Aguerre: Arte y Medios: Narrativa transmedia y el translector | Francisco Albarello: El lector en la encrucijada: la 
lectura/navegación en las pantallas digitales | María del Carmen Rosas Franco: Nuevos soportes, nuevos modos de leer. La narrativa en la Literatura infantil y juvenil digital | Florencia Lila Sorrentino: Instantáneas: la lectura en los tiempos que corren | Gustavo Bombini: Didáctica de la lectura y la escritura y multimodalidad | Mariana Landau: Los discursos sobre tecnologías y educación en la esfera pública | Mónica Pini: Políticas de alfabetización digital. Educación e inclusión | Lia Calabre: Planos de livro e leitura em tempos da cultura digital | Ana Ligia Medeiros y Gilda Olinto: O impacto da tecnologia de informação e comunicação nas bibliotecas públicas: envolvimento comunitário, criatividade e inovação | Eduardo Pereyra: Juventudes y TIC: Estados locales frente al abordaje de la promoción de la lectura | Daniela Szpilbarg: Configuraciones emergentes de circulación y lectura en el entorno digital: el caso de Bajalibros.com. (2019). Buenos Aires: Universidad de Palermo, Facultad de Diseño y Comunicación, Centro de Estudios en Diseño y Comunicación. Vol. 72, mayo. Con Arbitraje.

$>$ Cuadernos del Centro de Estudios en Diseño y Comunicación. [Ensayos]: Cruces entre Cultura y Diseño: repensando el diseño de los procesos culturales y los abordajes culturales del diseño. Karen Avenburg y Marina Matarrese: Introducción. Cruces entre Cultura y Diseño: repensando el diseño de los procesos culturales y los abordajes culturales del diseño | Ivana Mihal: Estéticas, lecturas e industria del libro: el caso de los e-books | Laura Ferreño y María Laura Giménez: Desafíos actuales de las políticas culturales. Análisis de caso en el Municipio de Avellaneda | Silvia Benza: El Distrito de Diseño en la Ciudad de Buenos Aires: una mirada desde los usos de la cultura en contextos globales y locales | Natalia Aguerre: Las performances musicales en las misiones jesuitas de guaraníes | Julieta Infantino: Arte y Transformación social. El aporte de artistas (circenses) en el diseño de políticas culturales urbanas | Verónica Griselda Talellis, Elsa Alicia Martínez, Karen Avenburg y Alina Cibea: Investigación y gestión cultural: diseñando articulaciones | Verónica Paiva y Alejo García de la Cárcova: Wright Mills y su crítica al diseño de segunda posguerra. Los aportes de la sociología al mundo del diseño | Laura Zambrini: Diseño e indumentaria: una mirada histórica sobre la estética de las identidades de género | Bárbara Guershman: Marcas de shopping o de diseñador. Los procesos de adscripción en la moda. (2019). Buenos Aires: Universidad de Palermo, Facultad de Diseño y Comunicación, Centro de Estudios en Diseño y Comunicación. Vol. 71, marzo. Con Arbitraje.

$>$ Cuadernos del Centro de Estudios en Diseño y Comunicación. [Ensayos]: Materialidad difusa.Prácticas de diseño y tendencias. Daniel Wolf: Prólogo de la Universidad de Palermo | Jorge Pokropek y Ana Cravino: Algunas precisiones sobre la borrosa noción de "Materia" para el diseño interior | Leila Lemgruber Queiroz: Desmaterialización e inmaterialidad en el contexto contemporáneo del Diseño | Maximiliano Zito: La sustentabilidad de Internet de las Cosas | Gabriela Nuri Barón: La des-materialización de productos tangibles en una perspectiva de sustentabilidad | Marina Andrea Baima: El proceso de diseño desde la génesis de los materiales | Marinella Ferrara and Valentina Rognoli: Introduction by the School of Design of Politecnico di Milano | Marinella Ferrara and Anna Cecilia Russo: The Italian Design Approach to Materials between tangible and intangible meanings | Linda Worbin: Designing for a start; irreversible dynamic textile patterns | Zurich Manuel 
Kretzer: Educating smart materials | Murat Bengisu: Biomimetic materials and design | Valentina Rognoli and Camilo Ayala Garcia: Material activism. New hybrid scenarios between design and technology | Giulia Gerosa and Laura Daglio: Diffuse materiality in public spaces between expressiveness and performance | Giovanni Maria Conti: Material for knitwear: a new contemporary design scenario | Giulio Ceppi: Slow+Design as sustainable sensoriality: an innovative approch aimed to explore the new relationships among design, innovation and sustainability. (2018). Buenos Aires: Universidad de Palermo, Facultad de Diseño y Comunicación, Centro de Estudios en Diseño y Comunicación. Vol. 70, diciembre. Con Arbitraje.

$>$ Cuadernos del Centro de Estudios en Diseño y Comunicación. [Ensayos]:Presente y futuro del diseño latino. María Verónica Barzola: Prólogo de la Universidad de Palermo | Rita Ribeiro: Prólogo da Universidade do Estado de Minas Gerais. FILOSOFÍA DEL DISEÑO Y CONTEXTO SOCIAL: Jorge Gaitto | María Verónica Barzola | Celso Carnos Scaletsky, Chiara Del Gaudio, Filipe Campelo Xavier da Costa, Gerry Derksen, Guilherme Corrêa Meyer, Juan de la Rosa, Piotr Michura y Stan Ruecker | Anderson Antonio Horta. EL DISEÑO COMO AGENTE DE TRANSFORMACIÓN SOCIAL: María Ledesma | Silvia Sasaoka, Giselle Marques Leite, Mônica Cristina de Moura y Luís Carlos Paschoarelli | Caroline Salvan Pagnan y Artur Caron Mottin | Simone Abreu | Zulma Buendía De Viana | Elisangela Batista. EL DISEÑO COMO FACTOR DE DESARROLLO ECONÓMICO: María del Rosario Bernatene y Guillermo Juan Canale | Liliana Durán Bobadilla y Luis Daniel Mancipe Lopez | Ana Urroz-Osés | Camilo de Lelis Belchior. FORMACIÓN PARA EL DISEÑO SOCIAL: Rita Aparecida da Conceição Ribeiro | Cristian Antoine, Santiago Aránguiz y Carolina Montt | Polyana Ferreira Lira da Cruz y Wellington Gomes de Medeiro | Carlos Henrique Xerfan do Amaral, André Ribeiro de Oliveira y Sandra Maria Nunes Vivone | Ana Beatriz Pereira de Andrade y Henrique Perazzi de Aquino. (2018). Buenos Aires: Universidad de Palermo, Facultad de Diseño y Comunicación, Centro de Estudios en Diseño y Comunicación. Vol. 69, septiembre. Con Arbitraje.

$>$ Cuadernos del Centro de Estudios en Diseño y Comunicación. [Ensayos]: Cine e Historia. Pluralidad de voces y miradas sobre el autoritarismo y el totalitarismo. Zulema Marzorati y Mercedes Pombo: Prólogo | Rodolfo Battagliese: Poder estatal y dominación de género: sus representaciones en La linterna roja (China, 1991) de Zhang Yimou | Lizel Tornay: Representaciones de mujeres en el cine de realizadoras feministas durante los períodos posdictatoriales. España y Argentina | Zulema Marzorati y Mercedes Pombo: El fascismo en la pantalla: Vincere (Italia, Bellochio, 2009) | Victoria Alvarez: Cine, represión y género en la transición democrática. Un análisis de La noche de los lápices | Tzvi Tal: La estética del trauma y el discurso de la memoria: personajes infantiles ante el terror estatal en Infancia clandestina (Ávila, Argentina, 2011) | Moira Cristiá: Frente el autoritarismo,la creación. La experiencia de AIDA y su relectura en el film El Exilio de Gardel (Fernando Solanas, Francia / Argentina, 1985) | Sonia Sasiain: El lugar del Estado en la representación de la vivienda popular: desde la construcción de la opinión pública hacia la censura | Mónica Gruber: Medios y poder: 1984. (2018). Buenos Aires: Universidad de Palermo, Facultad de Diseño y Comunicación, Centro de Estudios en Diseño y Comunicación. Vol. 68, julio. Con Arbitraje. 
$>$ Cuadernos del Centro de Estudios en Diseño y Comunicación. [Ensayos]: La dimensión ideológica de la enseñanza del diseño. Cecilia Mazzeo: Prólogo. La dimensión ideológica de la enseñanza del diseño | Constanza Necuzzi: Educación, enseñanza y didáctica en la contemporaneidad | Inés Olmedo: La Dirección de Arte en el cine, desafíos disciplinares y pedagógicos | Beatriz Galán: Reconstruyendo el entramado de una sociedad creativa. Estrategias para la formación de diseñadores en contextos de complejidad | Clara Ben Altabef: Intenciones para una didáctica proyectual. Caso: asignatura Proyecto y Forma en la FAU-UNT | Diego Giovanni Bermúdez Aguirre: El estado de posibilidad de la Historia del Diseño | María Ledesma: Luces y sombras en la enseñanza del Diseño. Una reflexión sobre su transformación en saber universitario | Ana Cravino: Enseñar Diseño: La emergencia de la teoría | Mabel Amanda López: Modos de decir y modos de ser: palabra e ideología en el taller de diseño | Ana María Romano: La construcción de la cosmovisión durante la enseñanza. (2018). Buenos Aires: Universidad de Palermo, Facultad de Diseño y Comunicación, Centro de Estudios en Diseño y Comunicación. Vol. 67, mayo. Con Arbitraje.

$>$ Cuadernos del Centro de Estudios en Diseño y Comunicación. [Ensayos]: Componentes del diseño audiovisual experimental. Gonzalo Aranda Toro y Alejandra Niedermaier: Prólogo | Alejandra Niedermaier: Introducción | María José Alcalde: Reflexión acerca del ejercicio audiovisual como medio de expresión del diseño gráfico experimental | Eugenia Álvarez Saavedra: El diseño en las representaciones audiovisuales de la etnia Mapuche | Laura Bertolotto Navarrete y Katherine Hetz Rodríguez: Reflexión respecto de la conexión entre la disciplina del diseño y la audiovisual, como factor estratégico de desarrollo | José Luis Cancio: Cerebus, un modelo de edición independiente | Rosa Chalkho: La música cinematográfica y la construcción del sentido en el film | Antonieta Clunes: Experimentación con medios análogos y su aplicación como recurso audiovisual, reflejo de un contexto latinoamericano | Daniela V. Di Bella: Ex Obra, la rematerialización de la imagen en movimiento | Pamela Petruska Gatica Ramírez: Ver y sentir (pantallas). Diseño, dispositivos y emoción | Ricardo Pérez Rivera: Acerca del método de la observación y algunos alcances al estudio experimental para la construcción de imágenes | Juan Manuel Pérez: Sobre subjetividades en la educación visual contemporánea: algunos componentes | Eduardo A. Russo: Aspectos intermediales de la enseñanza audiovisual. Un abordaje transversal, entre el cine y los nuevos medios | Gisela Massara, Camila Sabeckis y Eleonora Vallazza: Tendencias en el Cine Expandido Contemporáneo. (2018). Buenos Aires: Universidad de Palermo, Facultad de Diseño y Comunicación, Centro de Estudios en Diseño y Comunicación. Vol. 66, marzo. Con Arbitraje.

$>$ Cuadernos del Centro de Estudios en Diseño y Comunicación. [Ensayos]: Maestría en Diseño de la Universidad de Palermo [Catálogo de Tesis. 5a Edición. Ciclo 2014-2015]. (2017). Buenos Aires: Universidad de Palermo, Facultad de Diseño y Comunicación, Centro de Estudios en Diseño y Comunicación. Vol. 65, diciembre. Con Arbitraje.

$>$ Cuadernos del Centro de Estudios en Diseño y Comunicación. [Ensayos]: Los procesos emergentes en la enseñanza y la práctica del diseño. M. Veneziani: Prólogo $\mid$ M. Veneziani: Moda y comida: Una alianza que predice hechos económicos | M. Buey Fernández: 
Involúcrame y entenderé | F. Bertuzzi y D. Escobar: El espíritu emprendedor. Un acercamiento al diseño independiente de moda y las oportunidades de crecimiento comercial en el contexto actual argentino | X. González Eliçabe: Arte popular y diseño: los atributos de un nuevo lujo | C. Eiriz: Creación y operaciones de transformación. Aportes para una retórica del diseño | P.M. Doria: Desafío creativo cooperativo | V. Fiorini: Nuevos escenarios de las prácticas del diseño de indumentaria en Latinoamérica. Conceptos, metodologías e innovación productiva en el marco de la contemporaneidad | R. Aras: Los nuevos aprendizajes del sujeto digital | L. Mastantuono: Tendencias hacia un cine medioambiental. Concientización de una producción y diseño sustentable | D. Di Bella: El cuerpo como territorio | V. Stefanini: La mirada propia. El autorretrato en la fotografía contemporánea | S. Faerm: Introducción | A. Fry, R. Alexander, and S. Ladhib: Los emprendimientos en Diseño en la economía post-recesión: Parson`s E Lab, la Incubadora de Negocios de Diseño | S. Faerm: Desarrollando un nuevo valor en diseño; del "qué" al "cómo" | A. Kurennaya: Moda como práctica, Moda como proceso: los principios del lenguaje como marco para entender el proceso de diseño | L. Beltran-Rubio: Colombia for Export: Johanna Ortiz, Pepa Pombo y la recreación de la identidad cultural para el mercado global de la moda | A. Fry, G. Goretti, S. Ladhib, E. Cianfanelli, and C. Overby: "Artesanías de avanzada" integradas con el saber hacer; el papel del valor intangible y el rol central del artesano en el artesanato de alta gama del siglo $21 \mid$ T. Werner and S. Faerm: El uso de medios comerciales para involucrar e impactar de manera positiva en las comunidades. (2017). Buenos Aires: Universidad de Palermo, Facultad de Diseño y Comunicación, Centro de Estudios en Diseño y Comunicación. Vol. 64, septiembre. Con Arbitraje.

$>$ Cuadernos del Centro de Estudios en Diseño y Comunicación. [Ensayos]: Programa de Investigación de la Facultad de Diseño y Comunicación [Catálogo de Investigaciones. $1^{\text {a }}$ Edición. Ciclo 2007-2015). Investigaciones (abstracts) organizadas por campos temáticos: a. Empresas y marcas | b. Medios y estrategias de comunicación |c. Nuevas tecnologías |d. Nuevos profesionales $\mid$ e. Diseño y producción de objetos, espacios e imágenes $\mid$ f. Pedagogía del diseño y las comunicaciones $\mid$ g. Historia y tendencia. Selección de Investigaciones (completas): Patricia Dosio: Detección y abordaje de problemas o tendencias actuales en el arte y el diseño | Débora Belmes: Nuevas herramientas de la comunicación. Un estudio acerca del amor, la amistad, la educación y el trabajo en jóvenes universitarios | Eleonora Vallaza: El Found Footage como práctica del video-arte argentino de la última década | Andrés Olaizola: Alfabetización académica en entornos digitales | Marina Mendoza: Hacia la construcción de una ciudadanía mediática. Reflexiones sobre la influencia de las políticas neoliberales en la configuración de la comunicación pública argentina | Valeria Stefanini: Los modos de representación del cuerpo en la fotografía de moda. Producciones fotográficas de la Revista Catalogue. (2017). Buenos Aires: Universidad de Palermo, Facultad de Diseño y Comunicación, Centro de Estudios en Diseño y Comunicación. Vol. 63, julio. Con Arbitraje.

$>$ Cuadernos del Centro de Estudios en Diseño y Comunicación. [Ensayos]: Cine documental. Fernando Mazás: Prólogo | Igor Dimitri Gonçalves: Werner Herzog, documentales de viaje: Fata Morgana, La Soufrière, A la espera de una catástrofe inevitable, Wodaabe, Pastores del sol, Jag Mandir | Nerea González: La doble lectura de Canciones para 
después de una guerra explicada desde el marco teórico de las problemáticas del documental | Lucía Levis Bilsky: De artistas, consumidores y críticos: dinámicas del cambio, el gusto y la distinción en el campo artístico actual. Jean-Luc Godard y su Adiós al Lenguaje | Claudia Martins: Péter Forgács: imágenes de familia y la memoria del Holocausto | Fernando Mazás: Edificio Master: la tecnología audiovisual como escritura étnica | Carlos Gustavo Motta: La antropología visual | Gonzalo Murúa Losada: Por un cuarto cine, el webdoc en la era de las narraciones digitales | Antonio Romero Zurita: El cine intelectual de Fernando Birri. Antecedentes a la conformación del Documental Militante en Argentina | Maria A. Sifontes: El acto performático como expresión del pensamiento en obras realizadas por artistas venezolanos. (2017). Buenos Aires: Universidad de Palermo, Facultad de Diseño y Comunicación, Centro de Estudios en Diseño y Comunicación. Vol. 62, mayo. Con Arbitraje.

> Cuadernos del Centro de Estudios en Diseño y Comunicación. [Ensayos]: Imágenes/ escrituras: trazos reversibles. Laura Ruiz y Marcos Zangrandi: Presentación. El lazo imagen/escritura en los nexos de la cultura contemporánea. 1. Blogs/escrituras. Diego Vigna: Lo narrado en imágenes (o las imágenes narradas). Ficciones, pruebas, trazos y fotografías en las publicaciones de los escritores en blogs | Mariana Catalin: Daniel Link y la televisión: ensayos entre la clase y la cualificación. 2. Cine/escrituras. Vanina Escales: El ensayo a la búsqueda de la imagen | Diego A. Moreiras: Dimensiones de una masacre en la escuela: traducción intersemiótica en We need to talk about Kevin | Nicolás Suárez: Pueblo, comunidad y mito en Juan Moreira de Leonardo Favio y en Facundo. La sombra del Tigre de Nicolás Sarquís | Marcos Zangrandi: Antín / Cortázar: cruces y destiempos entre la escritura y el cine. 3. Imágenes/escrituras. Álvaro Fernández Bravo: Imágenes, trauma, memoria: miradas del pasado reciente en obras de Patricio Guzmán, Adriana Lestido y Gustavo Germano | Laura Ruiz: Bronce y sueños, los gitanos. Nomadismo, identidades por exclusión y otredad negativa en Jorge Nedich y Josef Koudelka | Santiago Ruiz y Ximena Triquell: Imágenes y palabras en la lucha por imposición de sentidos: la imagen como generadora de relatos. (2017). Buenos Aires: Universidad de Palermo, Facultad de Diseño y Comunicación, Centro de Estudios en Diseño y Comunicación. Vol. 61, marzo. Con Arbitraje.

$>$ Cuadernos del Centro de Estudios en Diseño y Comunicación. [Ensayos]: Lecturas y poéticas del arte latinoamericano: apropiaciones, rupturas y continuidades. María Gabriela Figueroa: Prólogo | Cecilia Iida: El arte local en el contexto global | Silvia Dolinko: Lecturas sobre el grabado en la Argentina a mediados del siglo XX | Ana Hib: Repertorio de artistas mujeres en la historiografía canónica del arte argentino: un panorama de encuentros y desencuentros | Cecilia Marina Slaby: Mito y banalización: el arte precolombino en el arte actual. La obra de Rimer Cardillo y su apropiación de la iconografía prehispánica | Lucía Acosta: Jorge Prelorán: las voces que aún podemos escuchar | Luz Horne: Un paisaje nuevo de lo posible. Hacia una conceptualización de la "ficción documental" a partir de Fotografías, de Andrés Di Tella | María Cristina Rossi: Redes latinoamericanas de arte constructivo | Florencia Garramuño: Todos somos antropófagos. Sobrevivencias de una vocación internacionalista en la cultura brasileña | Jazmín Adler: Artes electrónicas en Argentina. En busca del eslabón perdido. (2016). Buenos Aires: Universidad de Palermo, Facultad de Diseño y Comunicación, Centro de Estudios en Diseño y Comunicación. Vol. 60, diciembre. Con Arbitraje. 
$>$ Cuadernos del Centro de Estudios en Diseño y Comunicación. [Ensayos]: La experiencia fotográfica en diálogo con las experiencias del mundo. Alejandra Niedermaier: Prólogo | François Soulages: Geoestética de idas-vueltas (a modo de introducción) | Eric Bonnet: Partir y volver. Cuba, tierra natal de Wifredo Lam y Ana Mendieta | María Aurelia Di Berardino: Lo que oculta una frontera: el para qué escindir la ciencia del arte | Alejandro Erbetta: La experiencia migratoria como posibilidad de creación | Raquel Fonseca: En la frontera de las imágenes de una inmigración en doble sentido; ida y vuelta | Denise Labraga: Fronteras blandas. Posibilidades de representación del horror | Alejandra Niedermaier: La imagen síntoma: construcciones estéticas del yo | Pedro San Ginés Aguilar: Hijo de la migración | Silvia Solas: Fronteras artísticas: sentidos y sinsentidos de lo visual | François Soulages: Las fronteras \& el ida-vuelta | Joaquim Viana: Las transformaciones diagramáticas: imágenes y fronteras efímeras. (2016). Buenos Aires: Universidad de Palermo, Facultad de Diseño y Comunicación, Centro de Estudios en Diseño y Comunicación. Vol. 59, septiembre. Con Arbitraje.

$>$ Cuadernos del Centro de Estudios en Diseño y Comunicación. [Ensayos]: Cine y Moda. P. Doria: Prólogo Universidad de Palermo | M. Carlos: Moda en cine: signos y simbolismos | D. Ceccato: Cortos de moda, un género en auge | P. Doria: Brillos y utopías |V. Fiorini: Moda, cuerpo y cine |C. Garizoain: De la pasarela al cine, del cine a la pasarela. El vestuario y la moda en el cine argentino hoy $\mid$ M. Orta: Moda fantástica | S. Roffe: Vestuario de cine: El relator silencioso | M. Veneziani: Moda y cine: entre el relato y el ropaje | L. Acar: La seducción del cuerpo vestido en La fuente de las mujeres | F. di Cola: Moda y autenticidad histórica en el cine: nuevos ecos de la escuela viscontina $\mid \mathrm{E}$. Monteiro: El amor, los cuerpos y las ropas en Michael Haneke | D. Trindade: Vestes del tiempo: telas, movimientos e intervalos en la película Lavoura Arcaica | N. Villaça: Almodóvar: Cineasta y diseñador | F. Mazás: El cine come metalenguaje. Haciendo visible el código de la moda | Cuerpo, Arte y Diseño. P. Doria: Prólogo Universidad de Palermo | S. Cornejo y P. Estebecorena: Cuerpo, imagen e identidad. Relación (im)perfecta | D. Ceccato: Cuerpos encriptadas: Entre el ser real e irreal | L. Garabieta: Cuerpo y tiempo | G. Gómez del Río: Nuevos soportes, nuevos cuerpos | M. Matarrese: Cestería pilagá: una aproximación desde la estética al cuerpo | C. Puppo: El arte de diseñar nuestro cuerpo | S. Roffe: Ingeniería y arquitectura de la Moda: El cuerpo rediseñado | L. Ruiz: Imágenes de la otredad. Arte, política y cuerpos residuales en Daniel Santoro | V. Suárez: Cuerpos: utopías de lo real | S. Avelar: El futuro de la moda: una discusión posible | S. M. Costa, Esteban F. Tuesta \& S. A. Costa: Residuos agro-industriales utilizados como materiasprimas en estudios de desarrollo de fibras textiles | F. Dantas Mendes: El Diseño como estrategia de Postponement en la MVM Manufactura del Vestuario de la Moda | B. Ferreira Pires: Cuerpo trazado. Contexturas orgánicas e inorgánicas | C. R. Garcia Vicentini: El lugar de la creatividad en el desarrollo de productos de moda contemporáneos. (2016). Buenos Aires: Universidad de Palermo, Facultad de Diseño y Comunicación, Centro de Estudios en Diseño y Comunicación. Vol. 58, julio. Con Arbitraje.

$>$ Cuadernos del Centro de Estudios en Diseño y Comunicación. [Ensayos]: Moda en el siglo XX: una mirada desde las artes, los medios y la tecnología. Matilde Carlos: Prólogo | 
Melisa Perez y Perez: Las asociaciones entre el arte y la moda en el siglo XX | Mónica Silvia Incorvaia: La fotografía en la moda. Entre la seducción y el encanto | Gladys Mercado: Vestuario: entre el cine y la moda | Gabriela Gómez del Río: Fotolectos: cuando la imagen se vuelve espacio. Estudio de caso Para Ti Colecciones | Valeria Tuozzo: La moda en las sociedades modernas | Esteban Maioli: Moda, cuerpo e industria. Una revisión sobre la industria de la moda, el uso generalizado de TICs y la Tercera Revolución Industrial Informacional | Las Pymes y el mundo de la comunicación y los negocios. Patricia Iurcovich: Prólogo | Liliana Devoto: La sustentabilidad en las pymes, ¿es posible? | Sonia Grotz: Cómo transformar un sueño en un proyecto | María A. Rosa Dominici: La importancia del coaching en las PYMES como factor estratégico de cambio | Victoria Mejuto: La creación de diseño y marca en las Pymes | Diana Silveira: Las pymes argentinas: realidades y perspectivas | Christian Javier Klyver: Las Redes Sociales y las PyMES. Una relación productiva | Silvia Martinica: El maltrato psicológico en la empresa | Debora Shapira: La sucesión en las PYMES, el factor gerenciamiento. (2016). Buenos Aires: Universidad de Palermo, Facultad de Diseño y Comunicación, Centro de Estudios en Diseño y Comunicación. Vol. 57, marzo. Con Arbitraje.

$>$ Cuadernos del Centro de Estudios en Diseño y Comunicación. [Ensayos]: Pedagogías y poéticas de la imagen. Julio César Goyes Narváez y Alejandra Niedermaier: Prólogo | Vanessa Brasil Campos Rodríguez: Una mirada al borde del precipicio. La fascinación por lo siniestro en el espectáculo de lo real (reality show) | Mônica Ferreira Mayrink: La escuela en escena: las películas como signos mediadores de la formación crítico-reflexiva de profesores | Jesús González Requena: De los textos yoicos a los textos simbólicos | Julio César Goyes Narváez: Audiovisualidad y subjetividad. Del icono a la imagen fílmica Alejandro Jaramillo Hoyos: Poética de la imagen - imagen poética | Leopoldo Lituma Agüero: Imagen, memoria y Nación. La historia del Perú en sus imágenes primigenias | Luis Martín Arias: ¿Qué queremos decir cuando decimos “imagen”? Una aproximación desde la teoría de las funciones del lenguaje | Luis Eduardo Motta R.: La imagen y su función didáctica en la educación artística | Alejandra Niedermaier: Cuando me asalta el miedo, creo una imagen | Eduardo A. Russo: Dinámicas de pantalla, prácticas postespectatoriales y pedagogías de lo audiovisual | Viviana Suarez: Interferencias. Notas sobre el taller como territorio, la regla como posibilidad, la obra como médium | Lorenzo Javier Torres Hortelano: Aproximación a un modelo de representación virtual lúdico (MRVL). Virtual Self, narcisismo y ausencia de sentido. (2016). Buenos Aires: Universidad de Palermo, Facultad de Diseño y Comunicación, Centro de Estudios en Diseño y Comunicación. Vol. 56, marzo. Con Arbitraje.

> Cuadernos del Centro de Estudios en Diseño y Comunicación. [Ensayos]: Maestría en Diseño de la Universidad de Palermo [Catálogo de Tesis. $4^{a}$ Edición. Ciclo 2012-2013]. Tesis recomendada para su publicación: Mariluz Sarmiento: La relación entre la biónica y el diseño para los criterios de forma y función. (2015). Buenos Aires: Universidad de Palermo, Facultad de Diseño y Comunicación, Centro de Estudios en Diseño y Comunicación. Vol. 55, septiembre. Con Arbitraje. 
$>$ Cuadernos del Centro de Estudios en Diseño y Comunicación. [Ensayos]: Reflexiones sobre la imagen: un grito interminable e infinito. Jorge Couto: Prólogo | Joaquín Linne y Diego Basile: Adolescentes y redes sociales online. El photo sharing como motor de la sociabilidad | María José Bórquez: El Photoshop en guerra: algo más que un retoque cosmético | Virginia E. Zuleta: Una apertura de Pina. Algunas reflexiones en torno al documental de Wim Wenders | Lorena Steinberg: El funcionamiento indicial de la imagen en el nuevo cine documental latinoamericano | Fernando Mazás: Apuntes sobre el rol del audiovisual en una genealogía materialista de la representación | Florencia Larralde Armas: Las fotos sacadas de la ESMA por Victor Basterra en el Museo de Arte y Memoria de La Plata: el lugar de la imagen en los trabajos de la memoria de la última dictadura militar argentina | Tomás Frère Affanni: La imagen y la música. Apuntes a partir de El artista | Mariana Bavoleo: El Fileteado Porteño: motivos decorativos en el margen de la comunicación publicitaria | Mariela Acevedo: Una reflexión sobre los aportes de la Epistemología Feminista al campo de los estudios comunicacionales | Daniela Ceccato: Los blogs de moda como creadores de modelos estéticos | Natalia Garrido: Imagen digital y sitios de redes sociales en internet: ¿más allá de espectacularización de la vida cotidiana? | Eugenia Verónica Negreira: El color en la imagen: una relación del pasado - presente y futuro | Ayelén Zaretti: Cuerpos publicitarios: cuerpos de diseño. Las imágenes del cuerpo en el discurso publicitario de la televisión. Un análisis discursivo | Jorge Couto: La "belleza” im-posible visual/digital de las tapas de las revistas. Aportes de la biopolítica para entender su u-topia. (2015). Buenos Aires: Universidad de Palermo, Facultad de Diseño y Comunicación, Centro de Estudios en Diseño y Comunicación. Vol. 54, septiembre. Con Arbitraje.

$>$ Cuadernos del Centro de Estudios en Diseño y Comunicación. [Ensayos]: Interpretando el pensamiento de diseño del siglo XXI. Marisa Cuervo: Prólogo | Marcia Veneziani: Introducción Universidad de Palermo. Tendencias opuestas | Leandro Allochis: La mirada lúcida. Desafíos en la producción y recepción de imágenes en la comunicación contemporánea | Teresita Bonafina: Lo austero. ¿ Un estilo de vida o una tendencia en la moda? | Florencia Bustingorry: Moda y distinción social. Reflexiones en torno a los sentidos atribuidos a la moda | Carlos Caram: Pedagogía del diseño: el proyecto del proyecto | Patricia M. Doria: Poética, e inspiración en Diseño de Indumentaria | Verónica Fiorini: Tendencias de consumo, innovación e identidad en la moda: Transformaciones en la enseñanza del diseño latinoamericano | Paola Gallarato: Buscando el vacío. Reflexiones entre líneas sobre la forma del espacio | Andrea Pol: Brand 2020. El futuro de las marcas | José E. Putruele y Marcia C. Veneziani: Sustentabilidad, diseño y reciclaje | Valeria Stefanini: La puesta en escena. Arte y representación | Steven Faerm: Introducción Parsons The New School for Design. Nuevos mundos extremos | David Caroll: El innovador transgresor: ser un explorador de Google Glass | Aaron Fry y Steven Faerm: Consumismo en los Estados Unidos de la post-recesión: la influencia de lo "Barato y Chic" en la percepción sobre la desigualdad de ingresos | Steven Faerm: Construyendo las mejores prácticas en la enseñanza del diseño de moda: sentido, preparación e impacto | Robert Kirkbride: Aguas arriba/Aguas Abajo | Jeffrey Lieber: Aprender haciendo | Karinna Nobbs y Gretchen Harnick: Un estudio exploratorio sobre el servicio al cliente 
en la moda. (2015). Buenos Aires: Universidad de Palermo, Facultad de Diseño y Comunicación, Centro de Estudios en Diseño y Comunicación. Vol. 53, julio. Con Arbitraje.

$>$ Cuadernos del Centro de Estudios en Diseño y Comunicación. [Ensayos]: Cincuenta años de soledad. Aspectos y reflexiones sobre el universo del video arte. E. Vallazza: Prólogo | S. Torrente Prieto: La sutura de lo ausente. El espec-tador como actor en el videoarte | G. Galuppo: Frente al vacío cuerpos, espacios y gestos en el videoarte $\mid \mathrm{C}$. Sabeckis: El videoarte y su relación con las vanguardias históricas y cinematográficas | J. P. Lattanzi: La crisis de las grandes narrativas del arte en el audiovisual latinoamericano: apuntes sobre el cine experimental latinoamericano en las décadas de 1960 y 1970 | N. Sorrivas: El videoarte como herramienta pedagógica | M. Cantú: Archivos y video: no lo hemos comprendido todo | E. Vallazza: El video arte y la ausencia de un campo cultural específico como respuesta a su hibridación artística $\mid D$. Foresta: Los comienzos del videoarte (entrevista) | G. Ignoto: Borrado | J-P Fargier: Grand Canal \& Mon Gil! | R. Skryzak: Las ensoñaciones de un videasta solitario | G. Kortsarz: El sol en mi cabeza | La identidad nacional. Representaciones culturales en Argentina y Serbia. $Z$. Marzorati y B. Pantović: Prólogo | A. Mardikian: Múltiples identidades narrativas en el espacio teatral | D. Radojičić: Identidad cultural. La película etnográfica en Serbia $\mid$ M. Pombo: La fotografía argentina contemporánea. Una mirada hacia las comunidades indígenas | T. Tal: El Kruce de los Andes: memoria de San Martín y discurso político en Revolución (Ipiña, 2010) | B. Pantović: Serbia en imágenes: mensajes visuales de un país | V. Trifunović y J. Diković: La transformación post-socialista y la cultura popular: reflejo de la transición en series televisivas de Serbia | S. Sasiain: Espacios que educan: tres momentos en la historia de la educación en Argentina $\mid$ M. E. Stella: A un cuarto de siglo, reflexiones sobre el Juicio a las Juntas Militares en Argentina | A. Stagnaro: Representaciones culturales e identitarias en cambio: habitus científico y políticas públicas en ciencia y tecnología en la Argentina | A. Pavićević: El Ángel Blanco. Desde Heraldo de la Resurrección hasta Portador de Fortuna. Comercialización del Arte Religioso en la Serbia post-comunista $\mid$ M. Stefanović Banović: Ejemplos del uso de los símbolos cristianos en la vida cotidiana en Serbia (2015). Buenos Aires: Universidad de Palermo, Facultad de Diseño y Comunicación, Centro de Estudios en Diseño y Comunicación. Vol. 52, mayo. Con Arbitraje.

$>$ Cuadernos del Centro de Estudios en Diseño y Comunicación. [Ensayos]: Diseño de arte Tecnológico. Alejandra Niedermaier: Prólogo. Apartado: Acerca de FASE: Marcela Andino: Diseño de políticas culturales | Pelusa Borthwick: Nuestra inserción en la cadena de producción nacional | Patricia Moreira: FASE La necesidad del encuentro | Graciela Taquini: Textos curatoriales de los últimos cinco años de FASE. Apartado: Acerca de la esencia y el diseño del arte tecnológico. Rodrigo Alonso: Introducción a las instalaciones interactivas | Emiliano Causa: Cuerpo, Movimiento y Algoritmo | Rosa Chalhko: Entre al álbum y el MP3: variaciones en las tecnologías y las escuchas sociales | Alejandra Marinaro y Romina Flores: Objetos de frontera y arte tecnológico | Enrique Rivera Gallardo: El Virus de la Destrucción, o la defensa de lo inútil | Mariela Yeregui: Encrucijadas de las artes electrónicas en la aporía arte/investigación | Jorge Zuzulich: ¿Qué nos dice una 
obra de arte electrónico? Este cuaderno acompaña a FASE 6.0/2014. Tesis recomendada para su publicación. Valeria de Montserrat Gil Cruz: Gráficos animados en diarios digitales de México. Cápsulas informativas, participativas y de carácter lúdico. (2015). Buenos Aires: Universidad de Palermo, Facultad de Diseño y Comunicación, Centro de Estudios en Diseño y Comunicación. Vol. 51, marzo. Con Arbitraje.

$>$ Cuadernos del Centro de Estudios en Diseño y Comunicación. [Ensayos]: Diseños escénicos innovadores en puestas contemporáneas. Catalina Julia Artesi: Prólogo | Andrea Pontoriero: Vida líquida, teatro y narración en las propuestas escénicas de Mariano Pensotti | Estela Castronuovo: Lote 77 de Marcelo Mininno: el trabajoso oficio de narrar una identidad | Catalina Julia Artesi: Representaciones expandidas en puestas actuales | Ezequiel Lozano: La intermedialidad en el centro de las propuestas escénicas de Diego Casado Rubio | Marcelo Velázquez: Mediatización y diferencia. La búsqueda de la forma para una puesta en escena de Acreedores de Strindberg | Distribución cultural. Yanina Leandra: Prólogo | Andrea Hanna: El rol del productor en el teatro independiente. La producción es ejecutiva y algo más... | Roberto Perinelli: Teatro: de Independiente a Alternativo. Una síntesis del camino del Teatro Independiente argentino hacia la condición de alternativo y otras cuestiones inevitables | Leila Barenboim: Gestión Cultural 3.0 | Rosalía Celentano: Ámbito público, ámbito privado, ámbito independiente, fronteras desplazadas en el teatro de la Ciudad de Buenos Aires | Yoska Lazaro: La resignificación del término "producto" en el ámbito cultural | Tesis recomendada para su publicación: Rosa Judith Chalkho. Diseño sonoro y producción de sentido: la significación de los sonidos en los lenguajes audiovisuales (2014). Buenos Aires: Universidad de Palermo, Facultad de Diseño y Comunicación, Centro de Estudios en Diseño y Comunicación. Vol. 50, diciembre. Con Arbitraje.

$>$ Cuadernos del Centro de Estudios en Diseño y Comunicación. [Ensayos]: El Diseño en foco: modelos y reflexiones sobre el campo disciplinar y la enseñanza del diseño en América Latina. María Elena Onofre: Prólogo | Sandra Navarrete: Abstracción y expresión. Una reflexión de base filosófica sobre los procesos de diseño | Octavio Mercado G: Notas para un diseño negativo. Arte y política en el proceso de conformación del campo del Diseño Gráfico | Denise Dantas: Diseño centrado en el sujeto: una visión holística del diseño rumbo a la responsabilidad social | Sandra Navarrete: Diseño paramétrico. El gran desafío del siglo XXI | Deyanira Bedolla Pereda y Aarón José Caballero Quiroz: La imagen emotiva como lenguaje de la creatividad e innovación | María González de Cossío y Nora A. Morales Zaragoza: El pensamiento proyectual sistémico y su integración en el aula | Luis Rodríguez Morales: Hacia un diseño integral | Gloria Angélica Martínez de la Peña: La investigación y el diagnóstico de proyectos de diseño| María Isabel Martínez Galindo y Nora A. Morales Zaragoza: Imaginando otras formas de leer. La era de la sociedad imaginante | Paula Visoná y Giulio Palmitessa: Metodologías del diseño en la promoción de aprendizaje organizacional. El proyecto Melissa Academy | Leandro Brizuela: El diseño de packaging y su contribución al desarrollo de pequeños y medianos emprendimientos | Dolores Delucchi: El Diseño y su incidencia en la industria del juguete argentino | Pablo Capurro: Sin nadie en el medio. El papel de internet como 
intermediario en las industrias culturales y en la educación | Fabio Parode e Ione Bentz: El desarrollo sustentable en Brasil: cultura, medio ambiente y diseño. (2014). Buenos Aires: Universidad de Palermo, Facultad de Diseño y Comunicación, Centro de Estudios en Diseño y Comunicación. Vol. 49, septiembre. Con Arbitraje.

$>$ Cuadernos del Centro de Estudios en Diseño y Comunicación. [Ensayos]: Los enfoques multidisciplinarios del sistema de la moda. Marisa Cuervo: Prólogo | Marcia Veneziani: Introducción Universidad de Palermo. El enfoque multidisciplinario: un desafío pedagógico en la enseñanza de la moda y el diseño | Leandro Allochis: De New York a Buenos Aires y del Hip Hop a la Cumbia Villera. El protagonismo de la imagen en los procesos de transculturación | Patricia Doria: Sobre la Enseñanza del Diseño de Indumentaria. El desafío creativo (enseñanza del método) | Ximena González Eliçabe: Arte sartorial. De lo ritual a lo cotidiano | Sofía Marré: El asociativismo en las empresas de diseño de indumentaria de autor en Argentina | Laureano Mon: Los caminos de la innovación en la Argentina | Marcia Veneziani: Costumbres, dinero y códigos culturales: conceptos inseparables para la enseñanza del sistema de la moda | Maximiliano Zito: La ética del diseño sustentable. Steven Faerm: Introducción Parsons The New School for Design. Industria y Academia | Lauren Downing Peters: ¿Moda o vestido? Aspectos Pedagógicos en la teoría de la moda | Steven Faerm: Del aula al salón de diseño: La experiencia transicional del graduado en diseño de indumentaria | Aaron Fry, Steven Faerm y Reina Arakji: Realizando el sueño del nuevo graduado: construyendo el éxito sostenible de negocios en pequeña escala | Robert Kirkbride: Velos y veladuras | Melinda Wax: Meditaciones sobre una simple puntada. (2014). Buenos Aires: Universidad de Palermo, Facultad de Diseño y Comunicación, Centro de Estudios en Diseño y Comunicación. Vol. 48, junio. Con Arbitraje.

$>$ Cuadernos del Centro de Estudios en Diseño y Comunicación. [Ensayos]: Tejiendo identidades latinoamericanas. Marcia Veneziani: Prólogo | Manuel Carballo: Identidades: construcción y cambio | Roberto Aras: "Ortega, profeta del destino latinoamericano: la identidad como 'autenticidad'” | Marisa García: Latinoamérica según Latinoamérica | Leandro Allochis: La fotografía invisible. Identidad y tapas de revistas femeninas en la Argentina | Valeria Stefanini Zavallo: Pararse derechita. El cuerpo y la pose en la fotografía de moda. Un análisis de producciones fotográficas de la revista Catalogue | Marcia Veneziani: Diseñar a partir de la identidad. Entre el molde y el espejo | Paola de la Sotta Lazzerini - Osvaldo Muñoz Peralta: La intención de diseño. El caso del Artilugio Chilote | Ximena González Eliçabe: Arte textil y tradición en la Provincia de Catamarca, noroeste argentino | Lida Eugenia Lora Gómez - Diana Carolina Aconcha Díaz: FIBRARTE | Marina Porrúa: Claves de identidad del programa Identidades Productivas | Marina Porrúa: Diseño con identidad local. Territorio y cultura, como eje para el desarrollo y la sustentabilidad | Georgina Colzani: Entramado: moda y diseño en Latinoamérica | Andrea Melenje Argote: Itinerario: Diseño Gráfico, Cultura Visual e identidades locales | Nicolás García Recoaro: Las cholas y su mundo de polleras. (2014). Buenos Aires: Universidad de Palermo, Facultad de Diseño y Comunicación, Centro de Estudios en Diseño y Comunicación. Vol. 47, marzo. Con Arbitraje. 
$>$ Cuadernos del Centro de Estudios en Diseño y Comunicación. [Ensayos]: Maestría en Diseño de la Universidad de Palermo [Catálogo de Tesis. 3a Edición. Ciclo 2010-2011]. Tesis recomendada para su publicación: Yina Lissete Santisteban Balaguera: La influencia de los materiales en el significado de la joya. (2013). Buenos Aires: Universidad de Palermo, Facultad de Diseño y Comunicación, Centro de Estudios en Diseño y Comunicación. Vol. 46, diciembre. Con Arbitraje.

$>$ Cuadernos del Centro de Estudios en Diseño y Comunicación. [Ensayos]: Transformaciones en la comunicación, el arte y la cultura a partir del desarrollo y consolidación de nuevas tecnologías. T. Domenech: Prólogo | J. P. Lattanzi: ¿El poder de las nuevas tecnologías o las nuevas tecnologías y el poder? | G. Massara: Arte y nuevas tecnologías, lo experimental en el bioarte $\mid$ E. Vallazza: Nuevas tecnologías, arte y activismo político |C. Sabeckis: El séptimo arte en la era de la revolución tecnológica | V. Levato: Redes sociales, lenguaje y tecnología Facebook. The 4th Estate Media? | M. Damoni: Democracia y mass media... ¿ ¿mayor calidad de la información? | N. Rivero: La literatura en su época de reproductibilidad digital $\mid \mathrm{M}$. de la P. Garberoglio: Literatura y nuevas tecnologías. Cambios en las nociones de lectura y escritura a partir de los weblogs $\mid \mathrm{T}$. Domenech: Políticas culturales y nuevas tecnologías - Aportes interdisciplinares en Diseño y Comunicación desde el marketing, los negocios y la administración. S. G. González: Prólogo A. Bur: Marketing sustentable. Utilización del marketing sustentable en la industria textil y de la indumentaria $\mid$ A. Bur: Moda, estilo y ciclo de vida de los productos de la industria textil | S. Cabrera: La fidelización del cliente en negocios de restauración | S. Cabrera: Marketing gastronómico. La experiencia de convertir el momento del consumo en un recuerdo memorable $\mid$ C. R. Cerezo: De la Auditoría Contable a la Auditoría de las Comunicaciones | D. Elstein: La importancia de la motivación económica | S. G. González: La reputación como ventaja competitiva sostenible | E. Lissi: Primero la estrategia, luego el marketing. ¿Cómo conseguir recursos en las ONGs? | E. Llamas: La naturaleza estratégica del proceso de branding | D. A. Ontiveros: Retail marketing: el punto de venta, un medio poderoso $\mid$ A. Prats: La importancia de la comunicación en el marketing interno. (2013). Buenos Aires: Universidad de Palermo, Facultad de Diseño y Comunicación, Centro de Estudios en Diseño y Comunicación. Vol. 45, septiembre. Con Arbitraje.

$>$ Cuadernos del Centro de Estudios en Diseño y Comunicación. [Ensayos]: Moda y Arte. Marcia Veneziani: Prólogo Universidad de Palermo | Felisa Pinto: Fusión Arte y Moda | Diana Avellaneda: De perfumes que brillan y joyas que huelen. Objetos de la moda y talismanes de la fe | Diego Guerra y Marcelo Marino: Historias de familia. Retrato, indumentaria y moda en la construcción de la identidad a través de la colección Carlos Fernández y Fernández del Museo Fernández Blanco, 1870-1915 | Roberto E. Aras: Arte y moda: ¿fusión o encuentro? Reflexiones filosóficas | Marcia Veneziani: Moda y Arte en el diseño de autor argentino | Laureano Mon: Diseño en Argentina. "Hacia la construcción de nuevos paradigmas" | Victoria Lescano: Baño, De Loof y Romero, tres revolucionarios de la moda y el arte en Buenos Aires | Valeria Stefanini Zavallo: Para hablar de mí. La apropiación que el arte hace de la moda para abordar el problema de la identidad 
de género | María Valeria Tuozzo y Paula López: Moda y Arte. Campos en intersección | Maria Giuseppina Muzzarelli: Prólogo Università di Bologna | Maria Giuseppina Muzzarelli: El binomio arte y moda: etapas de un proceso histórico | Simona Segre Reinach: Renacimiento y naturalización del gusto. Una paradoja de la moda italiana | Federica Muzzarelli: La aventura de la fotografía como arte de la moda | Elisa Tosi Brandi: El arte en el proceso creativo de la moda: algunas consideraciones a partir de un caso de estudio | Nicoletta Giusti: Art works: organizar el trabajo creativo en la moda y en el arte Antonella Mascio: La moda como forma de valorización de las series de televisión. (2013). Buenos Aires: Universidad de Palermo, Facultad de Diseño y Comunicación, Centro de Estudios en Diseño y Comunicación. Vol. 44, junio. Con Arbitraje.

$>$ Cuadernos del Centro de Estudios en Diseño y Comunicación. [Ensayos]: Acerca de la subjetividad contemporánea: evidencias y reflexiones. Alejandra Niedermaier - Viviana Polo Flórez: Prólogo | Raúl Horacio Lamas: La Phantasía estructurante del pensamiento y de la subjetividad | Alejandra Niedermaier: La distribución de lo inteligible y lo sensible hoy | Susana Pérez Tort: Poéticas visuales mediadas por la tecnología. La necesaria opacidad | Alberto Carlos Romero Moscoso: Subjetividades inestables | Norberto Salerno: ¿Qué tienen de nuevo las nuevas subjetividades? | Magalí Turkenich - Patricia Flores: Principales aportes de la perspectiva de género para el estudio social y reflexivo de la ciencia, la tecnología y la innovación | Gustavo Adolfo Aragón Holguín: Consideración de la escritura narrativa como indagación de sí mismo | Cayetano José Cruz García: Idear la forma. Capacitación creativa | Daniela V. Di Bella: Aspectos inquietantes de la era de la subjetividad: lo deseable y lo posible | Paola Galvis Pedroza: Del universo simbólico al arte como terapia. Un camino de descubrimientos | Julio César Goyes Narváez: El sujeto en la experiencia de lo real | Sylvia Valdés: Subjetividad, creatividad y acción colectiva | Elizabeth Vejarano Soto: La poética de la forma. Fronteras desdibujadas entre el cuerpo, la palabra y la cosa | Eduardo Vigovsky: Los aportes de la creatividad ante la dificultad reflexiva del estudiante universitario | Julián Humberto Arias: Desarrollo humano: un lugar epistémico | Lucía Basterrechea: Subjetividad en la didáctica de las carreras proyectuales. Grupos de aprendizaje; evaluación | Tatiana Cuéllar Torres: Cartografía del papel de los artefactos en la subjetividad infantil. Un caso sobre la implementación de artefactos en educación de la primera infancia| Rosmery Dussán Aguirre: El Diseño de experiencias significativas en entornos de aprendizaje | Orfa Garzón Rayo: Apuntes iniciales para pensar-se la subjetividad que se expresa en los procesos de docencia en la educación superior | Alfredo Gutiérrez Borrero: Rapsodia para los sujetos por sí-mismos. Hacia una sociedad de localización participante | Viviana Polo Florez: Habitancia y comunidades de sentido. Complejidad humana y educación. Consideraciones acerca del acto educativo en Diseño. (2013). Buenos Aires: Universidad de Palermo, Facultad de Diseño y Comunicación, Centro de Estudios en Diseño y Comunicación. Vol. 43, marzo. Con Arbitraje.

$>$ Cuadernos del Centro de Estudios en Diseño y Comunicación. [Ensayos]: Perspectivas sobre moda, tendencias, comunicación, consumo, diseño, arte, ciencia y tecnología. Marcia Veneziani: Prólogo| Laureano Mon: Industrias Creativas de Diseño de Indumen- 
taria de Autor. Diagnóstico y desafíos a 10 años del surgimiento del fenómeno en Argentina | Marina Pérez Zelaschi: Observatorio de tendencias | Sofía Marré: La propiedad intelectual y el diseño de indumentaria de autor | Diana Avellaneda: Telas con efectos mágicos: iconografía en las distintas culturas. Entre el arte, la moda y la comunicación | Silvina Rival: Tiempos modernos. Entre lo moderno y lo arcaico: el cine de Jia Zhang-ke y Hong Sang-soo | Cristina Amalia López: Moda, Diseño, Técnica y Arte reunidos en el concepto del buen vestir. La esencia del oficio y el lenguaje de las formas estéticas del arte sartorial y su aporte a la cultura y el consumo del diseño | Patricia Doria: Consideraciones sobre moda, estilo y tendencias | Gustavo A. Valdés de León: Filosofía desde el placard. Modernidad, moda e ideología | Mario Quintili: Nanociencia y Nanotecnología... un mundo pequeño | Diana Pagano: Las tecnologías de la felicidad privada. Una problemática tan vieja como la modernidad | Elena Onofre: Al compás de la revolución Interactiva. Un mundo de conexiones | Roberto Aras: Principios para una ética de la ficción televisiva | Valeria Stefanini Zavallo: El uso del cuerpo en las revistas de moda | Andrea Pol: La marca: un signo de identificación visual y auditivo sinérgico. (2012). Buenos Aires: Universidad de Palermo, Facultad de Diseño y Comunicación, Centro de Estudios en Diseño y Comunicación. Vol. 42, septiembre. Con Arbitraje.

$>$ Cuadernos del Centro de Estudios en Diseño y Comunicación. [Ensayos]: Arte, Diseño y medias tecnológicas. Rosa Chalkho: Hacia una proyectualidad crítica. [Prólogo] | Florencia Battiti: El arte ante las paradojas de la representación | Mariano Dagatti: El voyeurismo virtual. Aportes a un estudio de la intimidad | Claudio Eiriz: El oído tiene razones que la física no conoce. (De la falla técnica a la ruptura ontológica) | María Cecilia Guerra Lage: Redes imaginarias y ciudades globales. El caso del stencil en Buenos Aires (2000-2007) | Mónica Jacobo: Videojuegos y arte. Primeras manifestaciones de Game Art en Argentina | Jorge Kleiman: Automatismo \& Imago. Aportes a la Investigación de la Imagen Inconsciente en las Artes Plásticas | Gustavo Kortsarz: La duchampizzación del arte | María Ledesma: Enunciación de la letra. Un ejercicio entre Occidente y Oriente | José Llano: La notación del intérprete. La construcción de un paisaje cultural a modo de huella material sobre Valparaíso | Carmelo Saitta: La banda sonora, su unidad de sentido | Sylvia Valdés: Poéticas de la imagen digital. (2012) Buenos Aires: Universidad de Palermo, Facultad de Diseño y Comunicación, Centro de Estudios en Diseño y Comunicación. Vol. 41, junio. Con Arbitraje.

$>$ Cuadernos del Centro de Estudios en Diseño y Comunicación. [Ensayos]: Relaciones Públicas al sur de Latinoamerica II. Una mirada regional de los nuevos escenarios y desafíos de la comunicación. Marisa Cuervo: Prólogo | Claudia Gil Cubillos: Presentación | Fernando Caniza: Lo público y lo privado en las Relaciones Públicas. Cómo pensar la identidad y pertenencia del alumno en estos ámbitos para comprender mejor su desempeño académico y su inserción profesional | Gustavo Cóppola: Gestión del Riesgo Comunicacional. Puesta en práctica | Maria Aparecida Ferrari: Comunicación y Cultura: análisis de la realidad de las Relaciones Públicas en organizaciones chilenas y brasileñas | Constanza Hormazábal: Reputación y manejo de Crisis: Caso empresas de telefonía móvil, luego del 27F en Chile | Patricia Iurcovich: La Pequeña y Mediana 
empresa y la función de la comunicación | Carina Mazzola: Repensar la comunicación en las organizaciones. Del pensamiento en línea hacia una mirada sobre la complejidad de las prácticas comunicacionales | André Menanteau: Transparencia y comunicación financiera | Edison Otero: Tecnología y organizaciones: de la comprensión a la intervención | Gabriela Pagani: ¿Se puede ser una empresa socialmente responsable sin comunicar? | Julio Reyes: Las Cuatro Dimensiones de la Comunicación Interna. (2012) Buenos Aires: Universidad de Palermo, Facultad de Diseño y Comunicación, Centro de Estudios en Diseño y Comunicación. Vol. 40, abril. Con Arbitraje.

$>$ Cuadernos del Centro de Estudios en Diseño y Comunicación. [Ensayos]: Alquimia de lenguajes: alfabetización, enunciación y comunicación. Alejandra Niedermaier: Prólogo | Eje: La alfabetización de las distintas disciplinas. Beatriz Robles. Bernardo Suárez. Claudio Eiriz. Gustavo A. Valdés de León. Mara Steiner. Hugo Salas. Fernando Luis Rolando Badell. María Torre. Daniel Tubío | Eje: Vasos comunicantes. Norberto Salerno. Viviana Suárez. Laura Gutman. Graciela Taquini. Alejandra Niedermaier | Eje: Nuevos modos de circulación, nuevos modos de comunicación. Débora Belmes. Verónica Devalle. Mercedes Pombo. Eduardo Russo. Verónica Joly. (2012) Buenos Aires: Universidad de Palermo, Facultad de Diseño y Comunicación, Centro de Estudios en Diseño y Comunicación. Vol. 39, marzo. Con Arbitraje.

$>$ Cuadernos del Centro de Estudios en Diseño y Comunicación. [Ensayos]: Maestría en Diseño de la Universidad de Palermo [Catálogo de Tesis. 2a Edición. Ciclo 2008-2009]. Tesis recomendada para su publicación: Paola Andrea Castillo Beltrán: Criterios transdiciplinares para el diseño de objetos lúdico-didácticos. (2011) Buenos Aires: Universidad de Palermo, Facultad de Diseño y Comunicación, Centro de Estudios en Diseño y Comunicación. Vol. 38, diciembre. Con Arbitraje.

$>$ Cuadernos del Centro de Estudios en Diseño y Comunicación. [Ensayos]: El Diseño de Interiores en la Historia. Roberto Céspedes: El Diseño de Interiores en la Historia. Andrea Peresan Martínez: Antigüedad. Alberto Martín Isidoro: Bizancio. Alejandra Palermo: Alta Edad Media: Románico. Alicia Dios: Baja Edad Media: Gótico. Ana Cravino: Renacimiento, Manierismo, Barroco. Clelia Mirna Domoñi: Iberoamericano Colonial. Gabriela Garófalo: Siglo XIX. Mercedes Pombo: Siglo XX. Maestría en Diseño de la Universidad de Palermo. Tesis recomendada para su publicación. Mauricio León Rincón: El relato de ciencia ficción como herramienta para el diseño industrial. (2011) Buenos Aires: Universidad de Palermo, Facultad de Diseño y Comunicación, Centro de Estudios en Diseño y Comunicación. Vol. 37, septiembre. Con Arbitraje.

$>$ Cuadernos del Centro de Estudios en Diseño y Comunicación. [Ensayos]: Picas (2011) Buenos Aires: Universidad de Palermo, Facultad de Diseño y Comunicación, Centro de Estudios en Diseño y Comunicación. Vol. 36, junio. Con Arbitraje.

$>$ Cuadernos del Centro de Estudios en Diseño y Comunicación. [Ensayos]: Relaciones Públicas, nuevos paradigmas ¿más dudas que certezas? Paola Lattuada: Relaciones 
Públicas, nuevos paradigmas ¿más dudas que certezas? Fernando Arango: Comunicaciones corporativas. Damián Martínez Lahitou: Brand PR: comunicaciones de marca. Manuel Montaner Rodríguez: La gestión de las PR a través de Twitter. Orlando Daniel Di Pino: Avanza la tecnología, que se salve el contenido! Lucas Lanza y Natalia Fidel: Política 2.0 y la comunicación en tiempos modernos. Daniel Néstor Yasky: Los públicos de las comunicaciones financieras. Investor relations \& financial communications. Andrea Paula Lojo: Los públicos internos en la construcción de la imagen corporativa. Gustavo Adrián Pedace: Las Relaciones Públicas y la mentira: ¿inseparables? Gabriel Pablo Stortini: La ética en las Relaciones Públicas. Gerardo Sanguine: Las prácticas profesionales en la carrera de Relaciones Públicas. Paola Lattuada: Comunicación Sustentable: la posibilidad de construir sentido con otros. Adriana Lauro: RSE - Comunicación para el Desarrollo Sostenible en una empresa de servicio básico y social: Caso Aysa. (2011) Buenos Aires: Universidad de Palermo, Facultad de Diseño y Comunicación, Centro de Estudios en Diseño y Comunicación. Vol. 35, marzo. Con Arbitraje.

$>$ Cuadernos del Centro de Estudios en Diseño y Comunicación. [Ensayos]: La utilización de clásicos en la puesta en escena. Catalina Artesi: Tensión entre los ejes de lo clásico y lo contemporáneo en dos versiones escénicas de directores argentinos. Andrés Olaizola: La Celestina en la versión de Daniel Suárez Marzal: apuntes sobre su puesta en escena. María Laura Pereyra: Antígona, desde el teatro clásico al Derecho Puro - Perspectivas de la enseñanza a través del método del case study. María Laura Ríos: Manifiesto de Niños, o la escenificación de la violencia. Mariano Saba: Pelayo y el gran teatro del canon: los condicionamientos críticos de Unamuno dramaturgo según su recepción en América Latina. Propuestas de abordaje frente a las problemáticas de la diversidad. Nuevas estrategias en educación superior, desarrollo turístico y comunicación. Florencia Bustingorry: Sin barreras lingüísticas en el aula. La universidad argentina como escenario del multiculturalismo. Diego Navarro: Turismo: portal de la diversidad cultural. El turismo receptivo como espacio para el encuentro multicultural. Virginia Pineau: La Educación Superior como un espacio de construcción del Patrimonio Cultural. Una forma de entender la diversidad. Irene Scaletzky: La construcción del espacio académico: ciencia y diversidad. Maestría en Diseño de la Universidad de Palermo. Tesis recomendada para su publicación. Yaffa Nahir I. Gómez Barrera: La Cultura del Diseño, estrategia para la generación de valor e innovación en la PyMe del Área Metropolitana del Centro Occidente, Colombia. (2010) Buenos Aires: Universidad de Palermo, Facultad de Diseño y Comunicación, Centro de Estudios en Diseño y Comunicación. Vol. 34, diciembre. Con Arbitraje.

$>$ Cuadernos del Centro de Estudios en Diseño y Comunicación. [Ensayos]: Relaciones Públicas, al sur de Latinoamérica. Paola Lattuada: Relaciones Públicas, al sur de Latinoamérica. Daniel Scheinsohn: Comunicación Estratégica ${ }^{\circledR}$. María Isabel Muñoz Antonin: Reputación corporativa: Trustmark y activo de comportamientos adquisitivos futuros. Bernardo García: Tendencias y desafíos de las marcas globales. Nuevas expectativas sobre el rol del comunicador corporativo. Claudia Gil Cubillos: Comunicadores corporativos: desafíos de una formación profesional por competencias en la era global. Marce- 
lino Garay Madariaga: Comunicación y liderazgo: sin comunicación no hay líder. Jairo Ortiz Gonzales: El rol del comunicador en la era digital. Alberto Arébalos: Las nuevas relaciones con los medios. En un mundo de comunicaciones directas, ¿es necesario hacer media relations? Enrique Correa Ríos: Comunicación y lobby. Guillermo Holzmann: Comunicación política y calidad democrática en Latinoamérica. Paola Lattuada: RSE y RRPP: ¿un mismo ADN? Equipo de Comunicaciones Corporativas de MasterCard para la región de Latinoamérica y el Caribe: RSE - Caso líder en consumo inteligente. (2010) Buenos Aires: Universidad de Palermo, Facultad de Diseño y Comunicación, Centro de Estudios en Diseño y Comunicación. Vol. 33, agosto. Con Arbitraje.

$>$ Cuadernos del Centro de Estudios en Diseño y Comunicación. [Ensayos]: txts. (2010) Buenos Aires: Universidad de Palermo, Facultad de Diseño y Comunicación, Centro de Estudios en Diseño y Comunicación. Vol. 32, mayo. Con Arbitraje.

$>$ Cuadernos del Centro de Estudios en Diseño y Comunicación. [Ensayos]: Maestría en Diseño de la Universidad de Palermo [Catálogo de Tesis. $1^{a}$ Edición. Ciclo 2004-2007]. Tesis recomendada para su publicación: Nancy Viviana Reinhardt: Infografía Didáctica: producción interdisciplinaria de infografías didácticas para la diversidad cultural. (2010) Buenos Aires: Universidad de Palermo, Facultad de Diseño y Comunicación, Centro de Estudios en Diseño y Comunicación. Vol. 31, abril. Con Arbitraje.

$>$ Cuadernos del Centro de Estudios en Diseño y Comunicación. [Ensayos]: El paisaje como referente de diseño. Jimena Martignoni: El paisaje como referente de diseño. Carlos Coccia: Escenografía. Teatro. Paisaje. Cristina Felsenhardt: Arquitectura. Paisaje. Graciela Novoa: Historia. Marcas a través del tiempo. Paisaje. Andrea Saltzman: Cuerpo. Vestido. Paisaje. Sandra Siviero: Antropología. Pueblos. Paisaje. Felipe Uribe de Bedout: Mobiliario Urbano. Espacio Público. Ciudad - Paisaje. Paisaje Urbe. Patricia Noemí Casco y Edgardo M. Ruiz: Introducción Paisaje Urbe. Manifiesto: Red Argentina del Paisaje. Lorena C. Allemanni: Acciones sobre el principal recurso turístico de Villa Gesell "la playa". Gabriela Benito: Paisaje como recurso ambiental. Gabriel Burgueño: El paisaje natural en el diseño de espacios verdes. Patricia Noemí Casco: Paisaje compartido. Paisaje como recurso. Fabio Márquez: Diseño participativo de espacios verdes públicos. Sebastián Miguel: Proyecto social en áreas marginales de la ciudad. Eduardo Otaviani: El espacio público, sostén de las relaciones sociales. Blanca Rotundo y María Isabel Pérez Molina: El hombre como hacedor del paisaje. Edgardo M. Ruiz: Patrimonio, historia y diseño de los jardines del Palacio San José. Fabio A. Solari y Laura Cazorla: Valoración de la calidad y fragilidad visual del paisaje. (2009) Buenos Aires: Universidad de Palermo, Facultad de Diseño y Comunicación, Centro de Estudios en Diseño y Comunicación. Vol. 30, noviembre. Con Arbitraje.

> Cuadernos del Centro de Estudios en Diseño y Comunicación. [Ensayos]: Typo. (2009) Buenos Aires: Universidad de Palermo, Facultad de Diseño y Comunicación, Centro de Estudios en Diseño y Comunicación. Vol. 29, agosto. Con Arbitraje. 
$>$ Cuadernos del Centro de Estudios en Diseño y Comunicación. [Ensayos]: Relaciones Públicas 2009. Radiografía: proyecciones y desafíos. Paola Lattuada: Introducción. Fernando Arango: La medición de la reputación corporativa. Alberto Arébalos: Yendo donde están las audiencias. Internet: el nuevo aliado de las relaciones públicas. Alessandro Barbosa Lima y Federico Rey Lennon: La Web 2.0: el nuevo espacio público. Lorenzo A. Blanco: entrevista. Lorenzo A. Blanco: ¿Nuevas empresas... nuevas tendencias... nuevas relaciones públicas...? Carlos Castro Zuñeda: La opinión pública como el gran grupo de interés de las relaciones públicas. Marisa Cuervo: El desafío de la comunicación interna en las organizaciones. Diego Dillenberger: Comunicación política. Graciela Fernández Ivern: Consejo Profesional de Relaciones Públicas de la República Argentina. Carta abierta en el $50^{\circ}$ aniversario. Juan Iramain: La sustentabilidad corporativa como objetivo estratégico de las relaciones públicas. Patricia Iurcovich: Las pymes y la función de la comunicación. Gabriela T. Kurincic: Convergencia de medios en Argentina. Paola Lattuada: RSE: Responsabilidad Social Empresaria. La tríada RSE. Aldo Leporatti: Issues Management. La comunicación de proyectos de inversión ambientalmente sensibles. Elisabeth Lewis Jones: El beneficio público de las relaciones públicas. Un escenario en el que todos ganan. Hernán Maurette: La comunicación con el gobierno. Allan McCrea Steele: Los nuevos caminos de la comunicación: las experiencias multisensoriales. Daniel Scheinsohn: Comunicación Estratégica ${ }^{\circledR}$. Roberto Starke: Lobby, lobistas y bicicletas. Hernán Stella: La comunicación de crisis. (2009) Buenos Aires: Universidad de Palermo, Facultad de Diseño y Comunicación, Centro de Estudios en Diseño y Comunicación. Vol. 28, abril. Con Arbitraje.

$>$ Cuadernos del Centro de Estudios en Diseño y Comunicación. [Ensayos]: Sandro Benedetto: Borges y la música. Alberto Farina: El cine en Borges. Alejandra Niedermaier: Algunas consideraciones sobre la fotografía a través de la cosmovisión de Jorge Luis Borges. Graciela Taquini: Transborges. Nora Tristezza: El arte de Borges. Florencia Bustingorry y Valeria Mugica: La fotografía como soporte de la memoria. Andrea Chame: Fotografía: los creadores de verdad o de ficción. Mónica Incorvaia: Fotografía y Realidad. Viviana Suárez: Imágenes opacas. La realidad a través de la máquina surrealista o el desplazamiento de la visión clara. Daniel Tubío: Innovación, imagen y realidad: ¿Sólo una cuestión de tecnologías? Augusto Zanela: La tecnología se sepulta a sí misma. (2008) Buenos Aires: Universidad de Palermo, Facultad de Diseño y Comunicación, Centro de Estudios en Diseño y Comunicación. Vol. 27, diciembre. Con Arbitraje.

$>$ Cuadernos del Centro de Estudios en Diseño y Comunicación. [Ensayos]: Catalina Julia Artesi: ¿Un Gardel venezolano? “El día que me quieras” de José Ignacio Cabrujas. Marcelo Bianchi Bustos: Latinoamérica: la tierra de Rulfo y de García Márquez. Reflexiones en torno a algunas cuestiones para pensar la identidad. Silvia Gago: Los límites del arte. María José Herrera: Arte Precolombino Andino. Alejandra Viviana Maddonni: Ricardo Carpani: arte, gráfica y militancia política. Alicia Poderti: La inserción de Latinoamérica en el mundo globalizado. Andrea Pontoriero: La identidad como proceso de construcción. Reapropiaciones de textualidades isabelinas a la luz de la farsa porteña. Gustavo Valdés de León: Latinoamérica en la trama del diseño. Entre la utopía y la realidad. (2008) Buenos 
Aires: Universidad de Palermo, Facultad de Diseño y Comunicación, Centro de Estudios en Diseño y Comunicación. Vol. 26, agosto. Con Arbitraje.

> Cuadernos del Centro de Estudios en Diseño y Comunicación. [Ensayos]: Guillermo Desimone. Sobreviviendo a la interferencia. Daniela V. Di Bella. Arte Tecnomedial: Programa curricular. Leonardo Maldonado. La aparición de la estrella en el cine clásico norteamericano. Su incidencia formal en la instancia enunciativa del film hollywoodense. (2008) Buenos Aires: Universidad de Palermo, Facultad de Diseño y Comunicación, Centro de Estudios en Diseño y Comunicación. Vol. 25, abril. Con Arbitraje.

$>$ Cuadernos del Centro de Estudios en Diseño y Comunicación. [Ensayos]: Rosa Judith Chalkho: Introducción: artes, tecnologías y huellas históricas. Norberto Cambiasso: El oído inalámbrico. Diseño sonoro, auralidad y tecnología en el futurismo italiano. Máximo Eseverri: La batalla por la forma. Belén Gache: Literatura y máquinas. Iliana Hernández García: Arquitectura, Diseño y nuevos medios: una perspectiva crítica en la obra de Antoni Muntadas. Fernando Luis Rolando: Arte, Diseño y nuevos medios. La variación de la noción de inmaterialidad en los territorios virtuales. Eduardo A. Russo: La movilización del ojo electrónico. Fronteras y continuidades en El arca rusa de Alexander Sokurov, o del plano cinematográfico y sus fundamentos (por fin cuestionados). Graciela Taquini: Ver del video. Daniel Varela: Algunos problemas en torno al concepto de música interactiva. (2007) Buenos Aires: Universidad de Palermo, Facultad de Diseño y Comunicación, Centro de Estudios en Diseño y Comunicación. Vol. 24, agosto. Con Arbitraje.

$>$ Cuadernos del Centro de Estudios en Diseño y Comunicación. [Ensayos]: Sebastián Gil Miranda. Entre la ética y la estética en la sociedad de consumo. La responsabilidad profesional en Diseño y Comunicación. Fabián Iriarte. Entre el déficit temático y el advenimiento del guionista compatible. Dante Palma. La inconmensurabilidad en la era de la comunicación. Reflexiones acerca del relativismo cultural y las comunidades cerradas. Viviana Suárez. El diseñador imaginario [La creatividad en las disciplinas de diseño]. Gustavo A. Valdés de León. Diseño experimental: una utopía posible. Marcos Zangrandi. Eslóganes televisivos: emergentes tautistas. (2007) Buenos Aires: Universidad de Palermo, Facultad de Diseño y Comunicación, Centro de Estudios en Diseño y Comunicación. Vol. 23, junio. Con Arbitraje.

$>$ Cuadernos del Centro de Estudios en Diseño y Comunicación. [Ensayos]: Sylvia Valdés. Diseño y Comunicación. Investigación de posgrado y hermenéutica. Daniela Chiappe. Medios de comunicación e-commerce. Análisis del contrato de lectura. Mariela D’Angelo. El signo icónico como elemento tipificador en la infografía. Noemí Galanternik. La intervención del Diseño en la representación de la información cultural: Análisis de la gráfica de los suplementos culturales de los diarios. María Eva Koziner. Diseño de Indumentaria argentino. Darnos a conocer al mundo. Julieta Sepich. La pasión mediática y mediatizada. Julieta Sepich. La producción televisiva. Retos del diseñador audiovisual. Marcelo Adrián Torres. Identidad y el patrimonio cultural. El caso de los sitios arqueológicos de la provincia de La Rioja. Marcela Verónica Zena. Representación de la cultura en el diario 
impreso: Análisis comunicacional. Facultad de Diseño y Comunicación. Universidad de Palermo. (2006) Buenos Aires: Universidad de Palermo, Facultad de Diseño y Comunicación, Centro de Estudios en Diseño y Comunicación. Vol. 22, noviembre. Con Arbitraje.

$>$ Cuadernos del Centro de Estudios en Diseño y Comunicación. [Ensayos]: Oscar Echevarría. Proyecto Maestría en Diseño. Facultad de Diseño y Comunicación. Universidad de Palermo. (2006) Buenos Aires: Universidad de Palermo, Facultad de Diseño y Comunicación, Centro de Estudios en Diseño y Comunicación. Vol. 21, julio. Con Arbitraje.

$>$ Cuadernos del Centro de Estudios en Diseño y Comunicación. [Ensayos]: Rosa Chalkho. Arte y tecnología. Francisco Ali-Brouchoud. Música: Arte. Rodrigo Alonso. Arte, ciencia y tecnología. Vínculos y desarrollo en Argentina. Daniela Di Bella. El tercer dominio. Jorge Haro. La escucha expandida [sonido, tecnología, arte y contexto] Jorge La Ferla. Las artes mediáticas interactivas corroen el alma. Juan Reyes. Perpendicularidad entre arte sonoro y música. Jorge Sad. Apuntes para una semiología del gesto y la interacción musical. (2006) Buenos Aires: Universidad de Palermo, Facultad de Diseño y Comunicación, Centro de Estudios en Diseño y Comunicación. Vol. 20, mayo. Con Arbitraje.

$>$ Cuadernos del Centro de Estudios en Diseño y Comunicación. [Ensayos]: Trabajos Finales de Grado. Proyectos de Graduación. Facultad de Diseño y Comunicación. Universidad de Palermo. Catálogo 1993-2004. (2005) Buenos Aires: Universidad de Palermo, Facultad de Diseño y Comunicación, Centro de Estudios en Diseño y Comunicación. Vol. 19, agosto. Con Arbitraje.

$>$ Cuadernos del Centro de Estudios en Diseño y Comunicación. [Ensayos]: Sylvia Valdés. Cine latinoamericano. Leandro Africano. Funcionalidad actual del séptimo arte. Julián Daniel Gutiérrez Albilla. Los olvidados de Luis Buñuel. Geoffrey Kantaris. Visiones de la violencia en el cine urbano latinoamericano. Joanna Page. Memoria y experimentación en el cine argentino contempoáneo. Erica Segre. Nacionalismo cultural y Buñuel en México. Marina Sheppard. Cine y resistencia. (2005) Buenos Aires: Universidad de Palermo, Facultad de Diseño y Comunicación, Centro de Estudios en Diseño y Comunicación. Vol. 18, mayo. Con Arbitraje.

$>$ Cuadernos del Centro de Estudios en Diseño y Comunicación. [Ensayos]: Guía de Artículos y Publicaciones de la Facultad de Diseño y Comunicación de la Universidad de Palermo. 1993-2004. (2004) Buenos Aires: Universidad de Palermo, Facultad de Diseño y Comunicación, Centro de Estudios en Diseño y Comunicación. Vol. 17, noviembre. Con Arbitraje.

$>$ Cuadernos del Centro de Estudios en Diseño y Comunicación. [Ensayos]: Alicia Banchero. Los lugares posibles de la creatividad. Débora Irina Belmes. El desafío de pensar. Creación - recreación. Rosa Judith Chalkho. Transdisciplina y percepción en las artes audiovisuales. Héctor Ferrari. Historietar. Fabián Iriarte. High concept en el escenario del Pitch: Herramientas de seducción en el mercado de proyectos fílmicos. Graciela Pacua- 
letto. Creatividad en la educación universitaria. Hacia la concepción de nuevos posibles. Sylvia Valdés. Funciones formales y discurso creativo. (2004) Buenos Aires: Universidad de Palermo, Facultad de Diseño y Comunicación, Centro de Estudios en Diseño y Comunicación. Vol. 16, junio. Con Arbitraje.

$>$ Cuadernos del Centro de Estudios en Diseño y Comunicación. [Ensayos]: Adriana Amado Suárez. Internet, o la lógica de la seducción. María Elsa Bettendorff. El tercero del juego. La imaginación creadora como nexo entre el pensar y el hacer. Sergio Caletti. Imaginación, positivismo y actividad proyectual. Breve disgresión acerca de los problemas del método y la creación. Alicia Entel. De la totalidad a la complejidad. Sobre la dicotomía ver-saber a la luz del pensamiento de Edgar Morin. Susana Finquelievich. De la tarta de manzanas a la estética bussines-pop. Nuevos lenguajes para la sociedad de la información. Claudia López Neglia. De las incertezas al tiempo subjetivo. Eduardo A Russo. La máquina de pensar. Notas para una genealogía de la relación entre teoría y práctica en Sergei Eisenstein. Gustavo Valdés. Bauhaus: crítica al saber sacralizado. (2003) Buenos Aires: Universidad de Palermo, Facultad de Diseño y Comunicación, Centro de Estudios en Diseño y Comunicación. Vol. 15, noviembre. Con Arbitraje.

$>$ Cuadernos del Centro de Estudios en Diseño y Comunicación. [Relevamientos Temáti$\cos$ ]: Noemí Galanternik. Tipografía on line. Relevamiento de sitios web sobre tipografía. Marcela Zena. Periódicos digitales en español. Publicaciones periódicas digitales de América Latina y España. (2003) Buenos Aires: Universidad de Palermo, Facultad de Diseño y Comunicación, Centro de Estudios en Diseño y Comunicación. Vol. 14, noviembre. Con Arbitraje.

> Cuaderno: Ensayos. José Guillermo Torres Arroyo. El paisaje, objeto de diseño. (2003) Buenos Aires: Universidad de Palermo, Facultad de Diseño y Comunicación, Centro de Estudios en Diseño y Comunicación. Vol. 13, junio.

$>$ Cuaderno: Recopilación Documental. Centro de Recursos para el Aprendizaje. Relevamientos Temáticos. Series: Práctica profesional. Diseño urbano. Edificios. Estudios de mercado. Medios. Objetos. Profesionales del diseño y la comunicación. Publicidad. (2003) Buenos Aires: Universidad de Palermo, Facultad de Diseño y Comunicación, Centro de Estudios en Diseño y Comunicación. Vol. 12, abril.

$>$ Cuaderno: Proyectos en el Aula. Creación, Producción e Investigación. Proyectos 2003 en Diseño y Comunicación. (2002) Buenos Aires: Universidad de Palermo, Facultad de Diseño y Comunicación, Centro de Estudios en Diseño y Comunicación. Vol. 11, diciembre

> Cuaderno: Proyectos en el Aula. Plan de Desarrollo Académico. Proyecto Anual. Proyectos de Exploración y Creación. Programa de Asistentes en Investigación. Líneas Temáticas. Centro de Recursos. Capacitación Docente. (2002) Buenos Aires: Universidad de Palermo, Facultad de Diseño y Comunicación, Centro de Estudios en Diseño y Comunicación. Vol. 10, septiembre. 
$>$ Cuaderno: Proyectos en el Aula: Espacios Académicos. Centro de Estudios en Diseño y Comunicación. Centro de Recursos para el aprendizaje. (2002) Buenos Aires: Universidad de Palermo, Facultad de Diseño y Comunicación, Centro de Estudios en Diseño y Comunicación. Vol. 9, agosto.

> Cuaderno: Proyectos en el Aula. Adriana Amado Suárez. Relevamiento terminológico en diseño y comunicación. A modo de encuadre teórico. Diana Berschadsky. Terminología en diseño de interiores. Área: materiales, revestimientos, acabados y terminaciones. Blanco, Lorenzo. Las Relaciones Públicas y su proyección institucional. Thais Calderón y María Alejandra Cristofani. Investigación documental de marcas nacionales. Jorge Falcone. De Altamira a Toy Story. Evolución de la animación cinematográfica. Claudia López Neglia. El trabajo de la creación. Graciela Pascualetto. Entre la información y el sabor del aprendizaje. Las producciones de los alumnos en el cruce de la cultura letrada, mediática y cibernética. (2002) Buenos Aires: Universidad de Palermo, Facultad de Diseño y Comunicación, Centro de Estudios en Diseño y Comunicación. Vol. 8, mayo.

> Cuaderno: Relevamiento Documental. María Laura Spina. Arte digital: Guía bibliográfica. (2001) Buenos Aires: Universidad de Palermo, Facultad de Diseño y Comunicación, Centro de Estudios en Diseño y Comunicación. Vol. 7, junio.

> Cuaderno: Proyectos en el Aula. Fernando Rolando. Arte Digital e interactividad. (2001) Buenos Aires: Universidad de Palermo, Facultad de Diseño y Comunicación, Centro de Estudios en Diseño y Comunicación. Vol. 6, mayo.

$>$ Cuaderno: Proyectos en el Aula. Débora Irina Belmes. Del cuerpo máquina a las máquinas del cuerpo. Sergio Guidalevich. Televisión informativa y de ficción en la construcción del sentido común en la vida cotidiana. Osvaldo Nupieri. El grupo como recurso pedagógico. Gustavo Valdés de León. Miseria de la teoría. (2001) Buenos Aires: Universidad de Palermo, Facultad de Diseño y Comunicación, Centro de Estudios en Diseño y Comunicación. Vol. 5 , mayo.

$>$ Cuaderno: Proyectos en el Aula. Creación, Producción e Investigación. Proyectos 2002 en Diseño y Comunicación. (2002) Buenos Aires: Universidad de Palermo, Facultad de Diseño y Comunicación, Centro de Estudios en Diseño y Comunicación. Vol. 4, julio.

> Cuaderno: Papers de Maestría. Cira Szklowin. Comunicación en el Espacio Público. Sistema de Comunicación Publicitaria en la vía pública de la Ciudad de Buenos Aires. (2002) Buenos Aires: Universidad de Palermo, Facultad de Diseño y Comunicación, Centro de Estudios en Diseño y Comunicación. Vol. 3, julio.

> Cuaderno: Material para el aprendizaje. Orlando Aprile. El Trabajo Final de Grado. Un compendio en primera aproximación. (2002) Buenos Aires: Universidad de Palermo, Facultad de Diseño y Comunicación, Centro de Estudios en Diseño y Comunicación. Vol. 2, marzo. 
> Cuaderno: Proyectos en el Aula. Lorenzo Blanco. Las medianas empresas como fuente de trabajo potencial para las Relaciones Públicas. Silvia Bordoy. Influencia de Internet en el ámbito de las Relaciones Públicas. (2000) Buenos Aires: Universidad de Palermo, Facultad de Diseño y Comunicación, Centro de Estudios en Diseño y Comunicación. Vol. 1 , septiembre. 


\section{Síntesis de las instrucciones para autores}

Cuadernos del Centro de Estudios en Diseño y Comunicación [Ensayos]

Facultad de Diseño y Comunicación. Universidad de Palermo. Buenos Aires, Argentina. www.palermo.edu/dyc

Los autores interesados deberán enviar un abstract de 200 palabras en español, inglés y portugués que incluirá 10 palabras clave. La extensión del ensayo no debe superar las 8000 palabras, deberá incluir títulos y subtítulos en negrita. Normas de citación APA. Bibliografía y notas en la sección final del ensayo.

Presentación en papel y soporte digital. La presentación deberá estar acompañada de una breve nota con el título del trabajo, aceptando la evaluación del mismo por el Comité de Arbitraje y un Curriculum Vitae.

\section{Artículos}

- Formato: textos en Word que no presenten ni sangrías ni efectos de texto o formato especiales.

. Autores: los artículos podrán tener uno o más autores.

. Extensión: entre 25.000 y 40.000 caracteres (sin espacio).

. Títulos y subtítulos: en negrita y en Mayúscula y minúscula.

. Fuente: Times New Roman. Estilo de la fuente: normal. Tamaño: 12 pt. Interlineado: sencillo.

. Tamaño de la página: A4.

. Normas: se debe tomar en cuenta las normas básicas de estilo de publicaciones de la American Psychological Association APA.

. Bibliografía y notas: en la sección final del artículo.

. Fotografías, cuadros o figuras: deben ser presentados en formato tif a 300 dpi en escala de grises. Importante: tener en cuenta que la imagen debe ir acompañando el texto a modo ilustrativo y dentro del artículo hacer referencia a la misma.

\section{Importante:}

La serie Cuadernos del Centro de Estudios en Diseño y Comunicación sostiene la exigencia de originalidad de los artículos de carácter científico que publica.

Es sistema de evaluación de los artículos se realiza en dos partes. En una primera instancia, el Comité Editorial evalúa la pertinencia de la temática del trabajo, para ser publicada en la revista. La segunda instancia corresponde a la evaluación del trabajo por especialistas. Se usa la modalidad de arbitraje doble ciego, permitiendo a la revista mantener la confidencialidad del proceso de evaluación.

Para la evaluación se solicita a los árbitros revisar los criterios de originalidad, pertinencia, actualidad, aportes, y rigurosidad científica. Será el Comité Editorial quien comunica a los autores los resultados de la misma.

\section{Consultas}

En caso de necesitar información adicional escribir a publicacionesdc@palermo.edu o ingresar a http://fido.palermo.edu/servicios_dyc/publicacionesdc/vista/instrucciones.php 





\section{UP

\section{Facultad de Diseño y Comunicación}

Mario Bravo 1050 . Ciudad Autónoma de Buenos Aires

C1175 ABT . Argentina . www.palermo.edu/dyc 